\title{
Fast pyrolysis of biomass
}

An experimental study on mechanisms influencing yield and composition of the products

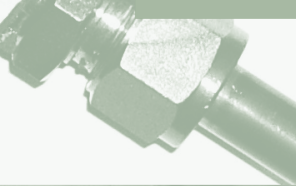




\section{Fast pyrolysis of biomass}

An experimental study on mechanisms influencing yield and composition of the products 


\section{Members of the committee}

Chairman/Secretary: Promoters:

Assistant promoter:

Members: prof. dr. G. van der Steenhoven prof. dr. S.R.A. Kersten prof. dr. ir. W.P.M. van Swaaij dr. ir. J.A. Hogendoorn

prof. dr. ir. W. Prins dr. D. Meier prof. dr.ir. G. Brem dr. ir. D.W.F. Brilman prof. dr. ir. L. Lefferts
University of Twente University of Twente University of Twente University of Twente

Ghent University, BTG vTI University of Twente University of Twente University of Twente

The research described in this Thesis was financially supported by the European Union through the BIOCOUP project within the $6^{\text {th }}$ Framework Program (contract number: 518312)

Ph.D. Thesis, University of Twente

E. Hoekstra, Enschede, The Netherlands, 2011

No part of this work may be reproduced by print, photocopy or any other means without the permission in writing from the author

Printed by Ipskamp Drukkers B.V., Enschede, The Netherlands.

Cover design by P.G. Kamp

Front cover is a photo collage of used laboratory equipment

ISBN: $\quad 978-90-365-3262-4$

DOI: $\quad 10.3990 / 1.9789036532624$ 


\title{
Fast pyrolysis of biomass
}

\section{An experimental study on mechanisms influencing yield and composition of the products}

\author{
PROEFSCHRIFT \\ ter verkrijging van de graad van doctor aan de Universiteit Twente, \\ op gezag van de rector magnificus, prof. dr. H. Brinksma, \\ volgens besluit van het College voor Promoties \\ in het openbaar te verdedigen \\ op vrijdag 11 november 2011 om 14.45 uur
}

door

\section{Elly Hoekstra}

geboren op 18 december 1981

te Geldrop 
Dit Proefschrift is goedgekeurd door de promotoren:

prof. dr. ir. W.P.M. van Swaaij

prof. dr. S.R.A. Kersten

en de assistent-promotor:

dr. Ir. J.A. Hogendoorn. 
aan Pieter 


\section{Contents}

Samenvatting 1

Summary $\quad 5$

$\begin{array}{lll}\text { Chapter } 1 & \text { Introduction }\end{array}$

$\begin{array}{lll}\text { Chapter } 2 & \text { Fast pyrolysis in a novel wire-mesh reactor: } & 21\end{array}$

initial decomposition products of pine wood

Chapter $3 \quad$ Fast pyrolysis in a novel wire-mesh reactor: $\quad 55$

decomposition of pine wood and model

compounds

Chapter 4 Homogeneous and heterogeneous reactions of

pyrolysis vapors from pine wood

Chapter 5 Fast pyrolysis of biomass in a fluidized bed reactor: in situ filtering of the vapors

Chapter 6 Possibilities and pitfalls in analyzing

(upgraded) pyrolysis oil by size exclusion chromatography (SEC)

Main conclusions

Dankwoord

Publications and presentations 


\section{Samenvatting}

Pyrolyse olie gemaakt uit biomassa heeft de potentie om "ruwe fossiele brandstoffen" te vervangen en om brandstoffen en chemicaliën op een duurzamere manier te produceren. Het voordeel van snelle pyrolyse als voorbewerkingstap is direct gerelateerd aan het feit dat het hoofdproduct vloeibaar is en een significante hogere energiedichtheid heeft $\left(\sim 1200 \mathrm{~kg} / \mathrm{m}^{3}\right)$ dan de oorspronkelijke biomassa $\left(\sim 150 \mathrm{~kg} / \mathrm{m}^{3}\right)$. De hieruit voortvloeiende transport en opslag voordelen leiden tot het concept van kleine decentrale snelle pyrolyse fabrieken voor de productie van olie die vervolgens naar een centrale verwerkingsfabriek wordt getransporteerd.

Ondanks het grote aantal studies is de kennis op het gebied van chemische reacties en fysische processen die plaatsvinden tijdens het snelle pyrolyse proces beperkt. Hetzelfde geldt voor de invloed van reactie condities op de opbrengsten en composities van de producten. Op basis van experimentele resultaten zijn vermeende proceseisen om hoge olie opbrengsten te krijgen recent betwist in de literatuur. Op dit moment ontbreekt de informatie om een betrouwbaar procesontwerp van een pyrolyse fabriek te maken op basis van wetenschappelijke resultaten. Dit proefschrift verschaft opheldering op twee gebieden:

Ten eerste zijn de initiële decompositie reacties in de converterende biomassa deeltjes en de transport processen van de gevormde fragmenten uit de converterende biomassa deeltjes bestudeerd.

Ten tweede zijn de homogene en heterogene reacties van de dampen (inclusief aërosolen) bestudeerd.

In deze studie zijn drie verschillende experimentele opstellingen ontworpen, gebouwd en operationeel gemaakt: i) een metaalgaas reactor ii) een buis reactor voor de conversie van dampen geplaatst in serie met een wervelbed pyrolyse reactor iii) een wervelbed reactor inclusief een ondergedompeld filter in het zand bed.

Het doel van de resultaten verkregen in deze opstellingen is het verschaffen van inzicht in de proces stappen die hierboven staan beschreven.

Er werd aangetoond dat in de metaalgaas reactor de biomassa deeltjes erg snel konden worden opgewarmd $\left(\sim 7000{ }^{0} \mathrm{C} / \mathrm{s}\right)$, de gevormde producten snel uit de (converterende) biomassa deeltjes konden worden getransporteerd en dat de verblijftijd van de dampen slechts 25 ms was. Meer dan 80 gew. \% olie werd verkregen gedurende de initiële decompositie processen. Deze waarde ligt significant hoger dan de pyrolyse olie opbrengsten (60-70 gew. \%) die over het algemeen in de literatuur worden gerapporteerd. Echter, er waren extreme condities nodig voor het verkrijgen van deze hoge olie opbrengst die niet realiseerbaar zijn in bestaande pyrolyse fabrieken op industriële schaal. Slechts kleine verschillen in olie compositie tussen deze olie en olie geproduceerd in "conventionele" wervelbed reactors zijn geobserveerd. 


\section{Samenvatting}

Tijdens het bestuderen van de homogene dampfase reacties, bleken homogene kraakreacties dominant te zijn over polymerisatie reacties. De opbrengsten waren onafhankelijk van de verblijftijd bij een dampfase temperatuur van $400{ }^{\circ} \mathrm{C}$. Echter veranderingen in de olie samenstelling hebben aangetoond dat er wel degelijk kraakreacties bij deze temperatuur hadden plaatsgevonden. Bij en boven een temperatuur van $500{ }^{\circ} \mathrm{C}$ nam initieel de gas opbrengst toe en de olie opbrengst af bij een toenemende verblijftijd. Voor langere verblijftijden (gemeten tot $15 \mathrm{~s}$ ) werd een temperatuur afhankelijke bijna stabiele waarde voor de opbrengsten bereikt $\left(500{ }^{0} \mathrm{C}: 57\right.$ gew. $\%_{\text {daf }}$, $550{ }^{0} \mathrm{C}: 49$ gew. $\%_{\text {daf }}$ ). De verkregen resultaten hebben laten zien dat zelfs bij lange verblijftijden een groot deel van de verscheidenheid aan dampmoleculen stabiel genoeg was bij temperaturen tot $550{ }^{\circ} \mathrm{C}$ om niet door te kraken naar gassen. Slechts een kleine hoeveelheid roet/kool werd gevormd vanuit een roet/kool vrije dampstroom op de reactor wand en filters, maar deze hoeveelheid was te klein om te kunnen kwantificeren.

Tijdens het bestuderen van de heterogene/gekatalyseerde dampfase reacties is er geobserveerd dat de kool hold-up op zich geen invloed had op de hoeveelheid damp die werd geproduceerd in een wervelbed pyrolyse reactor. Echter de aanwezigheid van mineralen $(\mathrm{Na} / \mathrm{K})$, zowel in de biomassa (oorspronkelijk of geïmpregneerd) als extern (als zout of in de kool), had grote invloed op het pyrolyse proces en wel in het bijzonder op de koolvormings-/ polymerisatiereacties. De koolopbrengst nam zelfs toe van 16 tot 42 gew. \% bij een $\mathrm{Na}$ en $\mathrm{K}$ hold-up van 0.7 gew. \% in de wervelbed reactor.

Experimenten in de metaalgaas reactor hebben aangetoond dat mineralen ook invloed hadden op de initiële decompositie processen van de biomassa deeltjes; een toename in koolopbrengst van 5 naar 10 gew. \% was geobserveerd voor dennenhout geïmpregneerd met kalium $\left(6.4 \cdot 10^{3} \mathrm{ppm}\right)$. Hoewel er duidelijk is aangetoond dat mineralen de initiële decompositie reacties beïnvloeden kon dit niet worden vastgesteld tijdens de experimenten uitgevoerd in de wervelbed reactor vanwege het overheersende effect van de externe interacties tussen de dampen en mineralen. Deze studie heeft aangetoond dat de contact tijd tussen dampen en mineralen geminimaliseerd moet worden en dat de ophoping van as in pyrolyse reactoren dient te worden voorkomen om een hoge olie opbrengst te verkrijgen.

Om het pyrolyse proces te intensiveren en om contact met ashoudende vaste deeltjes in wervelbed pyrolyse reactoren te voorkomen is er in eerder werk van onze vakgroep voorgesteld om filters te plaatsen in een wervelbed reactor.

In dit werk is er aangetoond dat het mogelijk is om een pyrolyse opstelling te draaien waarin de helft van de dampen werd verwijderd via een filter (porie grootte $5 \mu \mathrm{m}$ ) geplaatst in het wervelbed en de andere helft via een downstream cycloon. Typische downstream filter problemen gerelateerd aan een toename in drukval over het filter in de tijd werden niet geobserveerd met dit ondergedompelde filter. De gefilterde olie bevatte minder vaste deeltjes, alkali metalen en as in vergelijking tot de cycloon olie. Echter, ook de olie geproduceerd in de reeds efficiënte cycloon lijn bevatte slechts een kleine hoeveelheid van deze componenten (vaste deeltjes $<1$ gew. $\%$, as 0.03 gew. \%). Hoofdzakelijk kalium (K) was nog aanwezig in de gefilterde olie. Dit komt waarschijnlijk door de relatief hoge dampspanning van kaliumzouten. Echter, ondanks het lage kool/mineraal gehalte was de olie geproduceerd via de filter lijn nog steeds niet stabiel tijdens de opslag. 


\section{Samenvatting}

Uit ons werk volgt dat er in principe, onder extreme omstandigheden, verbeteringen mogelijk zijn in de olie opbrengst door in te grijpen in de initiële afbraakstappen van de biomassa en door de dampen snel te verwijderen. Er werd aangetoond dat de initiële afbraakreacties al door mineralen werden beïnvloed. Mineralen hebben ook een grote invloed op de dampfase reacties in pyrolyse reactoren. Verblijftijden van de pyrolyse dampen, zelfs in contact met kool (met uitzondering van mineralen) is minder kritisch dan vaak wordt aangenomen. 


\section{Summary}

Pyrolysis oil originating from biomass has the potential to replace 'crude fossil oil' and to produce fuels and chemicals in a more sustainable way. The favorable perspective of fast pyrolysis as biomass pre-treatment step is directly related to the production of a liquid as main product and the significantly higher density of the oil $\left(\sim 1200 \mathrm{~kg} / \mathrm{m}^{3}\right)$ compared to the original biomass $\left(\sim 150 \mathrm{~kg} / \mathrm{m}^{3}\right)$. The resulting transportation and storage benefits leads to the concept of small decentralized fast pyrolysis plants for production of oil to be transported to a central processing plant.

Despite the large number of studies, the understanding of the chemical reactions and physical processes occurring in the fast pyrolysis process is limited. The same holds for the influence of reaction conditions on the yield and composition of the products. Alleged process requirements to obtain high oil yields are recently challenged in literature, based on experimental evidence. At the moment information to make a reliable science based process design of a pyrolysis unit is lacking. This thesis provides clarification in two areas:

First, the initial decomposition reactions in the converting biomass in combination with the transport out of the particles of the decay fragments are studied.

Secondly, the homogeneous and heterogeneous reactions of the vapors (including aerosols) are investigated.

Three different experimental set-ups were designed, constructed and used in this study to this end: i) a wire-mesh reactor ii) a tubular vapor conversion reactor placed in series with a fluidized bed pyrolysis reactor and iii) a fluidized bed reactor including an immersed filter. The combination of the results obtained in these set-ups should give insight in the process steps described above.

In the wire-mesh reactor the biomass particles were heated very rapidly $\left(\sim 7000{ }^{0} \mathrm{C} / \mathrm{s}\right)$, the products were quickly transported out of the decomposing biomass particles and the residence time of the vapors was only $\sim 25 \mathrm{~ms}$. Over $80 \mathrm{wt} \%$ of oil on biomass was obtained during the initial decomposition processes, which is significantly higher than the yields (60-70 wt\%) typically reported in literature. Extreme conditions were required for this, which are not achievable in regular industrial fast pyrolysis units. Only minor variations in oil composition between this oil and oil produced in "conventional" fluidized reactors were observed. 


\section{Summary}

With respect to the homogeneous vapor conversion, homogeneous cracking reactions were found to be dominant over polymerization reactions. At $400{ }^{0} \mathrm{C}$ the yields were independent on the residence time, although changes in oil composition indicated that some cracking reactions had occurred. At and above a vapor temperature of $500{ }^{0} \mathrm{C}$ the gas yield increased and the oil yield decreased initially with residence time while for longer residence times (up to15 s) a temperature dependent almost stable oil yield was reached $\left(500{ }^{0} \mathrm{C}: 57 \mathrm{wt}_{\mathrm{daf}} \%, 550{ }^{0} \mathrm{C}: 49 \mathrm{wt} \%_{\mathrm{daf}}\right.$,). These results showed that a large part of the wide variety of vapor molecules was stable enough at temperatures up to $550{ }^{\circ} \mathrm{C}$ not to be cracked to gases, even at relatively long residence times. Only a small amount of soot/char was formed from a char free vapor stream on surfaces like the reactor wall and filter material, but this amount was too small to be quantified.

With respect to the heterogeneously influenced / catalyzed vapor conversions, it was observed that in a fluid bed pyrolysis reactor the char hold up as such had no influence on the vapor production. However, the presence of minerals $(\mathrm{Na} / \mathrm{K})$, either in the biomass matrix (native or impregnated) or external (as salt or in char), had much influence, especially on the charring/polymerization reactions. The char yield even increased from 16 till $42 \mathrm{wt} \%$ when a hold up of $0.7 \mathrm{wt} \%$ of $\mathrm{Na}$ and $\mathrm{K}$ was present in the fluidized bed reactor.

From experiments in the wire-mesh reactor, minerals were also shown to influence the initial decomposition reactions inside the biomass matrix; an increase in char yield from 5 till $10 \mathrm{wt} \%$ was observed for potassium impregnated pine $\left(6.4 \cdot 10^{3} \mathrm{ppm} \mathrm{K}\right)$ compared to untreated pine. Although minerals clearly influence the initial decomposition reactions this could not be established in the fluidized bed experiments because of the predominance of external interactions between the vapors and minerals. This study shows that the contact time between vapors and minerals should be minimized and build-up of ash inside pyrolysis reactors should be prevented to increase the oil production.

To intensify pyrolysis operation and to prevent intensive contact with the ash containing solids in fluid bed pyrolysers, in earlier work of our group, filters inside the fluid bed have been proposed.

In our work, it was shown to be possible to operate a pyrolysis unit in which half of the pyrolysis vapors were removed via a filter (pore size $5 \mu \mathrm{m}$ ) placed inside the fluidized bed and the other half via a downstream cyclone. Typical downstream vapor filtration problems related to an increase in pressure drop across the filter in time were not observed with this submerged filter. The filtered oil contained less solids, alkali metals and ash as compared to cyclone oil. However, also the oil produced via the efficient cyclone line contained already only a relatively small amount of those components (solids < $0.1 \mathrm{wt} \%$, ash $0.03 \mathrm{wt} \%$ ). Mainly potassium $(\mathrm{K})$ was still present in filtered pyrolysis oil, which is probably caused by the relatively high vapor pressure of the 


\section{Summary}

potassium salts. However, despite the low char/mineral content, the oil produced via filtering was still not stable during storage.

It follows from our work under extreme conditions that in principle improvements in the pyrolysis oil yields are possible by interfering with the initial break down steps and rapid removal of the vapors. Minerals were shown to influence the initial decomposition reactions already. The interference with the minerals also plays an important role in the vapor phase reactions in the pyrolysis reactor. Residence times of the vapors even in contact with the char (excluding the effect of minerals) is much less critical than often assumed. 
Chapter 1

\section{Introduction}

In this introduction the global energy problem is discussed, followed by a description of the (potential) role of biomass for the sustainable supply of energy and chemicals. Then, a brief introduction into fast pyrolysis, a thermochemical conversion route of biomass, is given. The investigation leading to the present thesis was carried out in the framework of an European project "BIOCOUP" which is shortly presented. Finally, the outline of the different chapters is given. 


\subsection{World energy supply}

The world's energy supply doubled over the last 35 years, and reached 515 EJ (12.267 Mtoe) in the year $2008^{1}$. The usage of this energy is not equally distributed: almost $50 \%$ of it is consumed in the industrialized economies (OECD countries) ${ }^{1}$, while only $18 \%$ of the world's population living there ${ }^{2}$ Fossil fuels provide $81 \%$, nuclear $6 \%$ and renewable energy sources $13 \%$ of today's total energy supply ${ }^{1}$ The use of fossil fuels has many adverse consequences. These include air pollution, acid rain, the dependence on politically unstable countries, addition of greenhouse gases to the atmosphere and the depletion of resources ${ }^{3}$. There is ongoing debate on the use of nuclear energy. Nuclear energy can generate electricity without the emission of greenhouse gases ${ }^{4}$, but there are rising concerns about radio-active waste disposal, (terrorist) attacks and accidents. The recent Fukushima accident on 11 March 2011 showed us that a nuclear power plant accident has drastic consequences for the environment. This accident led to a review of the usage of nuclear energy worldwide. For example, Germany is planning to close all its nuclear power plants by $2022^{5}$. Renewable energy includes wind, tidal, wave, solar, hydro, geothermal and biomass ${ }^{3}$. Bio-energy originates from materials derived from biological sources created by photosynthesis ${ }^{3}$. Today bio-energy (including traditional use) accounts for nearly two-thirds of all renewable energy sources ${ }^{6}$.

Although different energy scenarios are available $\left(\right.$ Shell $\left.^{7}, \mathrm{EIA}^{8}\right)$, they all agree that the energy demand will grow substantially in the coming years. For example Shell ${ }^{7}$ expects an increase in energy consumption of 47- $66 \%$ between 2010 and 2050. Fast developing countries like China and India will be mainly responsible for this growth. Worldwide proven oil ${ }^{9}$, natural gas $^{9}$ and coal $^{9}$ and nuclear ${ }^{4}$ reserves are expected to last for 46, 59, 118 and 80 years respectively. As a consequence, development of renewable energy technologies including bio-energy is crucial to global sustainability. For example, an increase in the usage of biomass up to a factor 2.7 between 2010 and 2050 is expected based on the scenarios prepared by Shell.

\subsection{Biomass and bio-fuels}

The use of biomass in addition to other renewable energy sources is important for several reasons. Firstly, biomass is the only source of renewable energy which contains carbon. This makes it a possible feed alternative for existing fossil based refinery and petrochemical industry ${ }^{10}$. Secondly, when combining biomass based processes with in situ $\mathrm{CO}_{2}$ sequestration, the $\mathrm{CO}_{2}$ concentration in the atmosphere can be reduced ${ }^{11}$. Finally, the use of biomass will also give incentives for economical development and job creation, especially in developing countries ${ }^{12}$. Unfortunately the use of biomass also has 
certain concerns: possible competition with the food chain, the required materials and energy for the production and transportation of biomass, the decrease of bio-diversity and soil exhaustion should be taken into consideration and, if necessary, counteracted.

The two main sources of biomass are purposely grown energy crops (e.g. woody crops and algae) and residues (e.g. forest, agricultural and industrial residues) ${ }^{3}$. First generation bio-fuels are based on the use of biomass feedstocks that can be used in the food chain. The sugars and vegetable oils in these feedstocks can be easily converted into ethanol and bio-diesel respectively ${ }^{10}$. Although many plants can make sugar and oil molecules, the majority of the plants on land consist mainly of lignocellulosic material: cellulose, hemicelluloses and lignin ${ }^{10,13}$. In the production of the so-called second generation biofuels non-food lignocellulosic biomass is used as feedstock. Figure 1.1 shows the composition and structure of the major compounds in lignocellulosic biomass. The biomass availability for first generation bio-fuels is very limited (<10 EJ/yr); for second generation bio-fuels it is significant (ca $100 \mathrm{EJ} / \mathrm{yr})^{10}$.

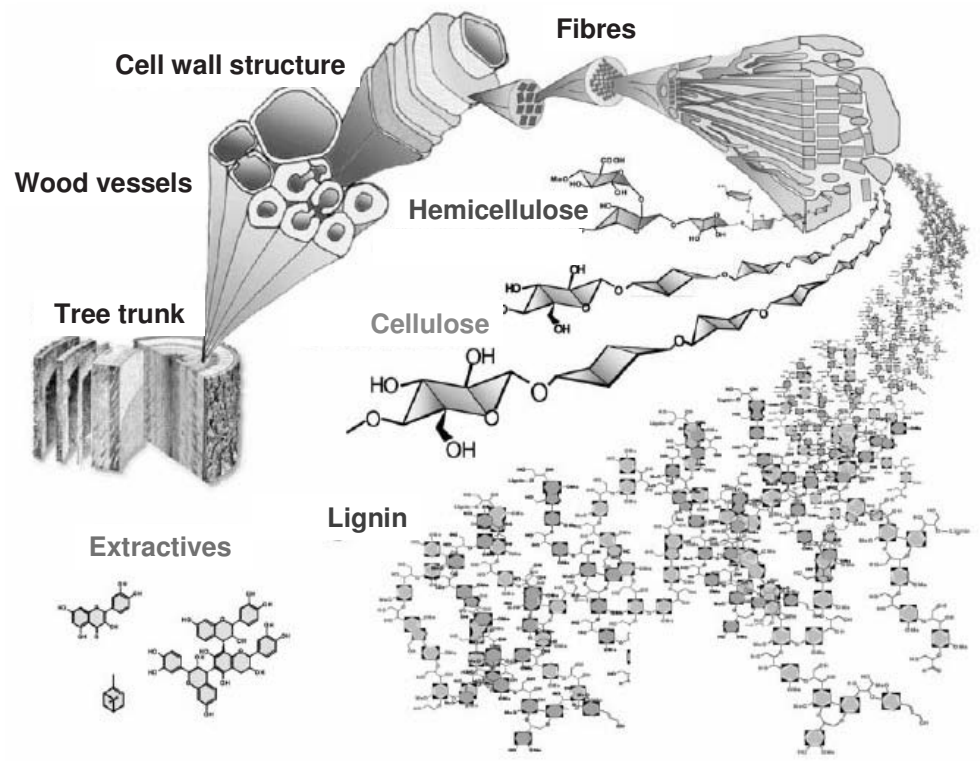

(C) Per Hoffmann, Oskar Faix and Ralph Lehnen

Figure 1.1 The composition of wood, illustrating the structure of lignocellulosic biomass ${ }^{14}$

There are several ways to convert biomass into energy. Biomass can be used directly (e.g. burning wood for heating and cooking) or indirectly by converting it first into liquid, solid or gaseous energy carriers that are used as feeds for downstream processing yielding heat, power, fuels, chemicals and materials. Basically there are three types of biomass conversion processes: mechanical/physical (e.g. oil extraction from seeds), biological 
(e.g. ethanol production by fermentation) and thermochemical processes ${ }^{3}$. Examples of the latter include combustion in power plants, gasification, torrefaction, pyrolysis, hydrothermal gasification and hydrothermal liquefaction. Combustion is the burning of biomass in the presence of oxygen. Less oxygen is used in the gasification process, while practically no oxygen is used during pyrolysis and torrefaction. Torrefaction and gasification have similarities with pyrolysis which is carried out at say $500{ }^{\circ} \mathrm{C}$, but the temperatures are lower $\left(200-300{ }^{\circ} \mathrm{C}\right)$ for torrefaction and higher $\left(750-1500{ }^{\circ} \mathrm{C}\right)$ for gasification $^{15}$. The main product for pyrolysis, torrefaction and gasification are oil, char (solid residue) and gas respectively. Hydrothermal processes have been developed for processing wet biomasses, including aqueous slurries, into more valuable products like oil and (syn) gas. So far, among the second generation biomass conversion processes only combustion of biomass has been commercialized on large scale (in power plants) ${ }^{3}$. However, biomass valorization beyond heat/electricity towards higher valued products like fuels, chemicals and materials is desirable. This thesis is about the fast pyrolysis of biomass: a process for converting biomass into an easier to handle liquid containing an abundance of organic chemicals (bio-oil or pyrolysis oil) with a much higher energy density on volume basis than the biomass it originates from.

\subsection{Fast pyrolysis of biomass}

In this introduction, only a brief description on fast pyrolysis will be given. Recently, extensive reviews on this topic were written by Kersten et al. (2005) ${ }^{16}$, Mohan et al. $(2006)^{13}$, Venderbosch and Prins $(2010)^{17}$ and Bridgwater $(2011)^{15}$ to which the reader may refer for more in depth information.

\subsubsection{Basic principles}

Fast pyrolysis is the thermochemical decomposition of organic material (moisture content typically $<10 \mathrm{wt} \%$ ) at $400-600{ }^{\circ} \mathrm{C}$ in the absence of oxygen. Under these conditions volatiles, gases and char are formed. After cooling, the vapors and aerosols are condensed to pyrolysis oil ${ }^{13,16,17}$. The volatiles consist of vapors and aerosols. In this thesis, both vapors and aerosols are denoted as vapors, but the reader should realize that "vapors" represent any combination of vapors and aerosols. Oil yields obtained using wood as feedstock are usually in the range of $60-70 \mathrm{wt} \%{ }^{17}$. The char yield is reported to be around $15-25 \mathrm{wt} \%$ and the yield of permanent gases between $10-20 \mathrm{wt} \%^{13}$. The oil, char and permanent gases typically contain 70,25 and $5 \%$ of the energy in the wood, respectively ${ }^{15}$. The pyrolysis process itself requires only about $15 \%$ of the energy, so the produced char and gas can be used to provide the energy for the fast pyrolysis process ${ }^{15}$. The exact yields (and composition) of the products depend on the feedstock and process parameters like temperature, pressure, heating rate, the size of the biomass particles, the residence time of the biomass particles, the volatile residence time and the presence of 
char/minerals ${ }^{13,15-17} \mathrm{~A}$ variety of reactor configurations has been developed and investigated among which (circulating) fluidized bed -, ablative -, rotating cone -, auger and vacuum pyrolysis reactors ${ }^{13,15,17}$ Alleged requirements on the process to obtain high oil yields are ${ }^{15}$ :

1) High heating rates, this requires usually particles of less than $3 \mathrm{~mm}$

2) Carefully controlled pyrolysis temperature around $500{ }^{\circ} \mathrm{C}$

3) Short vapor residence time of typically less than $2 \mathrm{~s}$

4) Rapid cooling of pyrolysis vapors

5) Rapid removal of product char to minimize cracking of vapors

In the last decade increased fundamental insight in pyrolysis has been obtained with also quite some experimentally observed exceptions to the aforementioned general 'design rules' ${ }^{18-20}$. A critical assessment of the 'design rules', their theoretical background and experimental verification seems therefore appropriate and is part of this thesis.

\subsubsection{Mechanism}

Biomass is a complex natural material (section 1.2, this introduction), with widely varying structural and compositional properties ${ }^{17}$. During fast pyrolysis of biomass a wide variety of chemical reactions and physical processes (e.g. sublimation, evaporation) take place. It seems impossible to map all pyrolysis reactions taking place. In literature, the chemical reactions are often classified as "primary" and "secondary" reactions ${ }^{13,15,17}$. To our opinion this classification is not useful and will not be used in this thesis, since the border between primary and secondary is not (and to our opinion cannot be) properly defined. We approach the fast pyrolysis process as a sequence of biomass decomposition reactions that are followed by homogeneous and heterogeneous vapor phase reactions. Heterogeneous reactions can proceed when produced vapors leave the reacting biomass particle, vapors encounter other particles (char, ash, catalysts) or when vapors are in contact with the (hot) reactor material. This complex interplay of chemical reactions and physical processes results in an oil containing hundreds of different compounds ${ }^{13,17}$.

\subsubsection{Oil composition}

Pyrolysis oil is a free flowing, typically dark brown liquid having a smoky odor. The elemental composition of it is close to that of the biomass it originates from, meaning it has a high oxygen content. Pyrolysis oil is a complex mixture of oxygenated organic compounds and water (15-30 wt\%) with a wide molecular weight range. Although various physico-chemical analytical techniques (e.g. viscosity, water content, and elemental composition) are available ${ }^{21}$, complete chemical characterization of pyrolysis oil at molecular level is not possible at the time of writing. Analyses like SEC, NMR, FTIR, HPLC, GCMS/FID are still under development. 
Basic properties for pyrolysis oil are listed in Table 1.1. Properties of heavy fuel oil are included in the same table as reference. Table 1.2 shows the chemical categorization of the organics in pyrolysis oil as compiled by Radlein ${ }^{22}$. Identified organic compounds include: hydroxyaldehydes, hydroxyketones, sugars, furans, furanones, pyranones, carboxylic acids, and phenolics ${ }^{22,23}$. Pyrolysis oil has a $\mathrm{pH}$ of 2-3 due to the presence of carboxylic acids and it has a significantly higher bulk density than biomass (1200 versus $\left.150 \mathrm{~kg} / \mathrm{m}^{3}\right)^{22,24}$ Due to the high oxygen content, the energy density of pyrolysis oil is only about half of that of fossil fuels and the oil is not miscible with petroleum derived fuels ${ }^{13,24}$ Pyrolysis liquids can only be partly vaporized: upon vacuum distillation residues up to $50 \mathrm{wt} \%$ are obtained ${ }^{24}$ However, recently it was shown that at high heating rates $\left(10^{6} \mathrm{C} / \mathrm{min}\right.$ ) the amount of solid residue can be lowered (to $8 \%$ on carbon basis) ${ }^{25}$ Even during storage at ambient temperature pyrolysis oil is not stable. Aging of pyrolysis during storage results in higher molecular weight compounds and an increase in water content $^{13,17}$.

Table1.1 Typical properties of pyrolysis oil (wood derived) and heavy fuel oil; data from Czernik and Bridgwater $^{24}$

\begin{tabular}{|l|l|l|}
\hline Physical Property & Pyrolysis-oil & Heavy fuel oil \\
\hline moisture content $[\mathrm{wt} \%]$ & $15-30$ & 0.1 \\
\hline $\mathrm{pH}[-]$ & 2.5 & - \\
\hline density $\left[\mathrm{kg} / \mathrm{m}^{3}\right]$ & 1200 & 940 \\
\hline elemental composition $[\mathrm{wt} \%]$ & & \\
\hline $\mathrm{C}$ & $54-58$ & 85 \\
\hline $\mathrm{H}$ & $5.5-7.0$ & 11 \\
\hline $\mathrm{O}$ & $35-40$ & 1.0 \\
\hline $\mathrm{N}$ & $0-0.2$ & 0.3 \\
\hline ash $[\mathrm{wt} \%]$ & $0-0.2$ & 0.1 \\
\hline $\mathrm{HHV}$ as produced $[\mathrm{MJ} / \mathrm{kg}]$ & $16-19$ & 40 \\
\hline Viscosity $\left(40{ }^{\circ} \mathrm{C}\right.$ and $25 \%$ water) $[\mathrm{mPa} \bullet \mathrm{s}]$ & $40-100$ & 180 \\
\hline Solids $($ char $)$ & $0.2-1 \mathrm{wt} \%$ & 1 \\
\hline Vacuum distillation residue & $\mathrm{Up} \mathrm{to} 50 \%$ & 1 \\
\hline
\end{tabular}

Table 1.2 Chemical compounds of pyrolysis oil originating from wood, data taken from Radlein ${ }^{22}$

\begin{tabular}{|l|l|}
\hline Compounds & wt $\%$ \\
\hline $\mathrm{C}_{1}:$ formic acid, methanol and formaldehyde & $5-10$ \\
\hline $\mathrm{C}_{2}-\mathrm{C}_{4}:$ linear hydroxyl and oxo substituted aldehydes and ketones & $15-35$ \\
\hline $\mathrm{C}_{5}-\mathrm{C}_{6}:$ hydroxyl, hydroxymethyl and/or oxo substituted furans, furanones and pyranones & $10-20$ \\
\hline $\mathrm{C}_{6}:$ Anhydrosugars (incl anhydro-oligosaccharides) & $6-10$ \\
\hline Water soluble carbohydrate derived oligomeric and polymeric material of uncertain composition & $5-10$ \\
\hline Monomeric methoxyl substituted phenols & $6-15$ \\
\hline Pyrolytic lignin & $15-30$ \\
\hline
\end{tabular}




\subsubsection{Applications}

Apart from the small market for flavour production (commercial pyrolysis-oil production by Ensyn for Red Arrows) ${ }^{15}$, a bulk market for pyrolysis oil still needs to be developed. Much (research) effort is aimed at finding and developing applications for pyrolysis oil.

Besides direct use for combustion ${ }^{24}$ pyrolysis oil is considered to be an intermediate to be used in subsequent processes ${ }^{15}$. For example, pyrolysis oil could be i) upgraded so the oil can be co-refined in a standard refinery unit to (blending compounds for) fuels ${ }^{6,24}$ ii) gasified to syngas followed by Fischer Tropsch synthesis to fuels/waxes or methanol synthesis $^{15,17}$ and iii) used as source for the extraction of chemicals (glycoaldehyde, levoglucosan, phenolics, acetic acid) ${ }^{15,24}$.

The potential of fast pyrolysis as pre-treatment step is directly related to the significantly higher density of the oil $\left(\sim 1200 \mathrm{~kg} / \mathrm{m}^{3}\right)$ compared to the original biomass $\left(\sim 150 \mathrm{~kg} / \mathrm{m}^{3}\right)$ and the possibility to remove and separately recover the majority of the minerals in the biomass. Biomass is widely distributed, so small scale conversion of biomass to pyrolysis oil near the biomass source will reduce transportation costs. As minerals are mainly incorporated in the char, fast pyrolysis allows recycling of the minerals as a natural fertilizer to the place where the biomass was grown. This leads to the concept of small decentralized fast pyrolysis units for production of oil to be transported to a central processing plant of similar scale as current petrochemical industry ${ }^{15,17}$.

In the past, research was focused on optimizing oil yields and finding applications for whole pyrolysis oil. Recently, some research projects were carried out in which the pyrolysis oil "quality"/composition was directly linked to its possible applications. This research suggests that optimum (whole) oil yield and application related "quality" are not necessarily related. Examples include: i) testing of pyrolysis oil in a gasification unit (850 $\left.{ }^{0} \mathrm{C}\right)$ revealed that the oil produced at the lower temperature $\left(360{ }^{0} \mathrm{C}\right)$ seems more suitable $^{26}$ ii) the anhydrosugars extracted from pyrolysis oil were successfully fermented to ethanol or lipids on labscale ${ }^{27}$.

\subsection{BIOCOUP: Co-processing of upgraded pyrolysis oil in standard refinery units}

The work in this thesis has been carried out under the framework of the European BIOCOUP project. The target of the European Union is to increase the share of renewable energy to $20 \%$ by $2020^{28}$. The aim of BIOCOUP was to develop a chain of process steps, starting with pyrolysis, which would allow biomass to be co-fed to a conventional oil refinery and to co-produce fuels and chemicals ${ }^{6}$ (see Figure 1.2). In the 
project it was shown that hydrodeoxygenated ${ }^{[1]}$ (HDO) pyrolysis oil could be successfully co-refined in lab scale refinery units ${ }^{6}$ and technologies for the extraction of aldehydes, phenolics and acids were optimized ${ }^{6}$. The optimized route was calculated to be competitive with conventional fuels when the price of gasoline is 1.5 times above current prices $^{6}$.

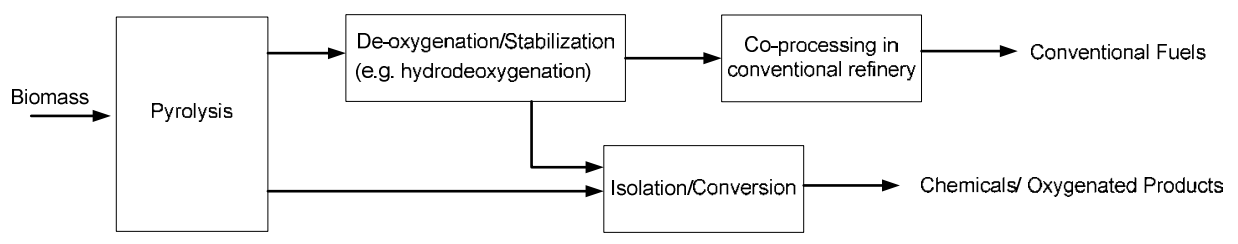

Figure 1.2 BIOCOUP's concept

\subsection{Outline thesis}

This thesis focuses on the basic mechanisms that are expected to have an important influence on product yields and composition during the fast pyrolysis process. Information on the independent effects of reaction conditions such as pressure, temperature, heating rate, solids residence time (holding time), volatiles residence time, and sample sizes on the yields and compositions is generally lacking in literature. There is need to determine the separate contribution of biomass decomposition processes and reactions inside the vapor phase to the overall pyrolysis process. With this information the possibilities to steer the product yields and compositions can be mapped and the predictability of the fast pyrolysis process is increased. Two principle research lines and one secondary line are addressed.

In chapter 2 and 3, the initial decomposition reactions in the biomass matrix are studied. Based on these insights it may be possible to identify methods to steer the final pyrolysis oil yield and composition. The influence of the following process parameters was studied: pressure, temperature, heating rate, holding time, biomass loading and vapor phase temperature. A novel wire-mesh reactor which was used for this research is described and validated in chapter 2. The results with pine wood as feedstock are presented and compared to results obtained using a more conventional fluidized bed reactor. More elaborate experimental results obtained using pine wood, pine wood $+\mathrm{KCl}$ and several model compounds (xylan, cellulose, lignin, levoglucosan, glucose) are reported in chapter 3. The results are interpreted using a physical-chemical mechanism describing the decomposition of biomass.

${ }^{[1]} \mathrm{T} \sim 220-340{ }^{\circ} \mathrm{C}, \mathrm{P} \sim 200$ bar, $\mathrm{H}_{2}$, catalyst 
Chapter 4 and 5 report about the influence of pyrolysis vapor phase reactions, i.e. the reactions taking place after the volatiles have escaped from the (decomposing) biomass matrix. The influence of homogeneous and heterogeneous pyrolysis vapor phase reactions is reported in chapter 4 . In this study two differently sized fluidized bed reactors were used: a $1 \mathrm{~kg} / \mathrm{hr}$ fluidized bed reactor and a $0.1 \mathrm{~kg} / \mathrm{hr}$ fluidized bed reactor connected to a tubular reactor. This study aims to obtain more unequivocal insight on the influence of the vapor phase temperature, residence time and the influence of char and minerals. The results are discussed in relation to kinetic model development and the engineering aspects of pyrolysis units. In chapter 5, a novel system to remove, in-situ, char/minerals from hot pyrolysis vapors is presented. Tests were carried out in the $1 \mathrm{~kg} / \mathrm{hr}$ fluidized bed reactor bed with immersed filters for extracting mineral low pyrolysis vapors. The influence of the filters on the operability of the process, the quality of the oil and char formation reactions in the vapor phase is discussed.

Characterization of biomass is by no mean trivial. Size exclusion chromatography (SEC) is often used to characterize pyrolysis oil, the actual possibilities and limitation of this method when applied to pyrolysis oil are not well understood. This technique has been studied and evaluated in chapter 6. The interpretation of the SEC chromatograms of pyrolysis oil samples appeared not to be so straightforward as for polymers for which SEC was originally developed.

Finally, the main conclusions of the present thesis are presented. 


\section{References}

12010 Key world energy statistics, International Energy Agency, www.iea.org visited August 2011

2. http://stats.oecd.org, visited August 2011

3. G. Boyle, Renewable energy power for a sustainable future, Oxford University Press, 2004

4. http://www.world-nuclear.org, visited August 2011

5. http://www.bbc.co.uk/news/world-europe-13592208, visited August 2011

6. www.biocoup.com, visited August 2011

7. Shell energy scenarios, http://www-static.shell.com, visited August 2011

8. International energy outlook 2010, www.eia.gov/oiaf/ieo, visited August 2011

9. BP statistical review of world energy, June 2011, www.bp.com, visited August 2011

10. Groeneveld MJ, The change from fossil to solar and biofuels needs our energy. Inaugural lecture. University of Twente, Enschede, 2008. Available at http://doc.utwente.nl/67339/

11. PhD-thesis P.Singh, Amine based solvent for $\mathrm{CO}_{2}$ absorption, form molecular structure to process, 2011

12. A. Demirbas, Political, economic and environmental impact of biofuels: a review, Applied Energy, 86, S108-S117, 2009

13. D. Mohan, C.U. Pittman, P.H. Steele, Pyrolysis of wood/biomass for bio-oil a critical review, Energy and Fuels, 20, 848-889, 2006

14. PhD-thesis, P. de Wild, Biomass pyrolysis for chemicals, 2011

15. A.V. Bridgwater, Review of fast pyrolysis of biomass and product upgrading, Biomass and bioenergy, article in press

16. Kersten S.R.A., Wang X., Prins W., van Swaaij W.P.M. Biomass pyrolysis in a fluidized bed reactor. Part 1: literature review and model simulations. Ind. Eng. Chem. Res., 44, 8773-8785, 2005

17. R.H. Venderbosch, W. Prins, Review: Fast pyrolysis technology development, Biofuels, Bioproducts Biorefining, 4(2), 178-208, 2010

18. R.J.M. Westerhof, D.W.F. Brilman, W.P.M. Van Swaaij, S.R.A. Kersten, Effect of temperature in fluidized bed fast pyrolysis of biomass: oil quality assessment in test units, Ind. Eng. Chem. Res., 49, 1160-1168, 2010

19. M. Garcia-Perez, X.S. Wang, J. Shen, M.J. Rhodes, F. Tian, W.J. Lee, H. Wu, C.Z. Li, Fast pyrolysis of oil mallee woody biomass: effect of temperature on the yield and quality of pyrolysis products. Ind. Eng. Chem. Res., 47, 1846-1854, 2008

20. D.S. Scott, P. Majerski, J. Piskorz, D. Radlein, A second look at fast pyrolysis of biomass - the RTI process. J. Anal. Appl. Pyrolysis, 51, 23-37, 1999

21. A. Oasmaa, C. Peacocke, A guide to physical property characterization of biomass-derived fast pyrolysis liquids, VTT Technical Research Centre of Finland Espoo 2001

22. D. Radlein, The production of chemicals from fast pyrolysis bio-oils in Fast pyrolysis of biomass: a handbook, volume 2, edited by A.V. Bridgwater, 2002

23. K. Sipila, E. Kuoppala, L. Fagernas, A. Oasmaa, Characterization of biomass-based flash pyrolysis oils, Biomass and Bioenergy, 14(2), 102-113, 1998

24. S, Czernik, A.V. Bridgwater, Overview of applications of biomass fast pyrolysis oil, Energy and fuels, 18, 590-598, 2004

25. G. van Rossum, B. Matas Guell, R.P. Balegedde Ramachandran, K. Seshan, L. Lefferts, W.P.M. van Swaaij, S.R.A. Kersten, Evaporation of pyrolysis oil: product distribution and residue char analysis, AIChE Journal, 56(8), 2010

26. R.J.M. Westerhof, D.W.F. Brilman, W.P.M. van Swaaij, S.R.A. Kersten, Effect of temperature in fluidized bed fast pyrolysis of biomass: oil quality assessment in test units, Ind. Eng. Chem. Res., 49, 1160-1168, 2010

27. J. Lian, S. Chen, S. Zhou, Z. Wang, J. O'Fallon, C.Z. Li, M. Garcia-Perez, Seperation, hydrolysis and fermentation of pyrolytic sugars to produce ethanol and lipids, Biosource Technology, 101, 9688-9699, 2010

28. http://ec.europa.eu/energy/renewables/biofuels/biofuels_en.htm, visited September 2011 
Chapter 2

\section{Fast pyrolysis in a novel wire-mesh reactor: initial decomposition products of pine wood}

Pyrolysis is known to occur by biomass decomposition processes followed by vapor phase reactions. The vapor phase reactions are typically considered to influence the pyrolysis oil composition and yield. However, it is not clear what yields and type of products are obtained after the initial decomposition reactions, neither is the pyrolysis reaction mechanism/rate in this initial phase well understood. The goal of this chapter is to study the initial decomposition processes of pine wood. For this, a novel wire-mesh reactor was constructed and used. In this set-up a small biomass sample $(<0.1 \mathrm{~g})$ was clamped between two meshes that were heated very fast (up to $10.000{ }^{\circ} \mathrm{C} / \mathrm{s}, \Delta T_{\text {mesh }} \pm 35$ ${ }^{0} \mathrm{C}$ ) by an electrical current. The mesh/feedstock was placed inside a vacumized, liquid nitrogen cooled vessel. These two last features were proven to result in a very low vapor life time (<15-25 ms compared to 1-2 s in a typical fast pyrolysis unit). The removal rate of volatiles from the (decomposing) biomass and vapor residence time and temperature could to a certain extent be increased by increasing the total pressure inside the reactor and by removing of the liquid nitrogen cooling. Reproducible results concerning yields (mass balance closures between 90 and $110 \mathrm{wt} \%$ ) and analysis were obtained (oil by SEC and NMR, gas by GC, char by FTIR). In this set-up the stainless steel wire-meshes did not appear to be catalytically active, which was validated using gold sputtered meshes. The yields and oil composition were changing with biomass loading from $0.05 \mathrm{~g}$ to $0.1 \mathrm{~g}$, despite the small sample amounts. Compared to more "conventional" pyrolysis processes, high oil yields (84 wt\%), very low char yields (5 wt\%) and low gas yields (8 $w t \%)$ were obtained. Using a high speed camera, movies were made and together with accompanying pressure profiles, it was possible to estimate the conversion rate. At a temperature of $500{ }^{\circ} \mathrm{C}$ the biomass conversion process was finished within $0.8 \mathrm{~s}$ which is clearly faster than previously reported in literature. Especially an increase in gas yield $(+14 w t \%$, mainly $C O)$ was observed in absence of cooling $\left(P_{\text {vad }}\right.$ No Cooling), while both the gas (+4 wt\%) and char yield (+3 wt\%) increased under atmospheric pressure $\left(P_{a t m} /\right.$ Cooling), all at the expense of oil yield. Compared to more "conventional" pyrolysis oil, the oil did contain: i) heavier molecules and ii) a non THF soluble sugar fraction. 


\subsection{Introduction}

Fast pyrolysis is a process in which organic materials (biomass) are rapidly heated to 400-600 ${ }^{\circ} \mathrm{C}$ in absence of oxygen. Under these conditions, vapors, aerosols, permanent gases and char are formed. The vapors and aerosols are condensed to a liquid called pyrolysis oil. Pyrolysis products are formed by a sequence of biomass decomposition ${ }^{1}$ reactions followed by vapor phase reactions ${ }^{2}$, which results in a mixture of water and hundreds of (oxygenated) organic compounds ${ }^{3}$. The exact composition of pyrolysis oil depends on a number of factors including the type of feedstock, particle size, reactor temperature, heating rate and vapor residence time ${ }^{4}$. A variety of reactor configurations has been investigated and developed among which (circulating) fluidized bed-, entrained flow- ablative-, rotating cone-, auger- and vacuum pyrolysis reactors ${ }^{4,5}$. These reactors differ with respect to heating rate, vapor residence time and temperature. Cracking and polymerization reactions are known to occur in the vapor phase at high temperatures ${ }^{2,6}$ (see chapter 4) and affect the pyrolysis oil yield and characteristics. The goal of this chapter is to study the initial decomposition reactions of the biomass matrix by fast removal and condensation of the volatiles. Based on these insights it may be possible to identify methods to steer the final pyrolysis oil composition.

Many techniques have already been used to study the biomass decomposition reactions in the pyrolysis process. Py-GC/MS and Py-MBMS, TGA, radiant flash pyrolysis, vacuum pyrolysis and wire-mesh reactors are the most well known techniques among them. Detailed information about the low molecular weight products can be obtained with PyGC/MS and Py-MBMS. Py-MBMS shows that biomass pyrolyses predominantly to monomers and monomer-related fragments from cellulose, hemicellulose and lignin ${ }^{7}$. Although the results obtained with these techniques are interesting, additional techniques are necessary to obtain information about product yields and the higher molecular weight products. Weight loss curves of biomass pyrolysis are obtained from TGA experiments, which have been used to determine the kinetics ${ }^{8}$. However, actual product yields cannot be determined and TGA's are operated at relatively low heating rates (up to 1000 ${ }^{0} \mathrm{C} / \mathrm{min}$ ). Complete mass balances can be obtained from radiant flash pyrolysis ${ }^{9,10}$ experiments. Using this method, Lede et $\mathrm{al}^{10,11}$ reported results that suggest the existence of an intermediate liquid compound during the pyrolysis of cellulose. They observed, contradictory to Py-GC/MS results ${ }^{12}$, high fractions of higher molecular weight components from the decomposition products of cellulose ${ }^{10}$. Unfortunately, information about the exact temperature could not be obtained in these radiant flash pyrolysis devices. In vacuum pyrolysis ${ }^{13}$ the vapors are quickly removed from the hot (decomposing) biomass/reactor, hence reducing their residence time and collision frequency, thereby minimizing vapor phase reactions and sequential reactions in the (decomposing) biomass. 
Higher oil yields are observed at vacuum pyrolysis compared to pyrolysis processes carried out at atmospheric pressure ${ }^{14}$.

We have chosen to design and construct a vacuum wire-mesh fast pyrolysis reactor to study the initial biomass decomposition reactions during the fast pyrolysis process. In this method, a finely ground biomass sample is clamped between two wire mesh layers, which are heated directly and very fast (up to $10.000{ }^{\circ} \mathrm{C} / \mathrm{s}$ ) by an electrical current. The mesh retains both the biomass and char particles, but offers little resistance to the passage of vapors and gases. Formed vapors and gases leave the hot zone very rapidly and will condense immediately on the liquid nitrogen cooled wall. In this paper this novel wiremesh reactor is described and validated. Furthermore the results with pine wood as feedstock will be presented and compared to results obtained using our more conventional fluidized bed reactor ${ }^{\text {(chapter 5)15-17. }}$.

\subsection{Overview wire-mesh reactors}

Over 40 years $^{18}$, several wire mesh reactors have been used to study the thermal decomposition of carbon containing materials. Other names used for these types of setups are: screen-heater, captive sample reactor, wire net apparatus and heated grid reactor. Different types of feedstock (coal ${ }^{19-30}$, plastic $^{31}$, cellulose ${ }^{14,32,33}, \operatorname{lignin}^{34,35}$, and biomass ${ }^{36-}$ ${ }^{56}$ ) were (hydro) pyrolyzed/combusted. An overview of wire-mesh reactors used to study the fast pyrolysis process of biomass/model compounds is listed in Table 2.1 and will be discussed briefly.

Experiments were carried out at temperatures up to $1127{ }^{\circ} \mathrm{C}$, pressures between 0.1 and 70 bars at heating rates from 0.1 till $15.000{ }^{\circ} \mathrm{C} / \mathrm{s}$ and holding-times (time at constant temperature) from zero till $300 \mathrm{~s}$. However, the majority of the experiments were carried out with heating rates up to $1000{ }^{\circ} \mathrm{C} / \mathrm{s}$ at atmospheric pressure. A number of reactors was equipped with a forced sweep-gas to rapidly remove the volatiles and gases. The temperatures were commonly measured with thermocouples. Several methods to determine the pyrolysis product yields and to analyse the products were used. If reported, the amount of char was determined by the weight difference between the mesh/sample before and after an experiment. The gas yield was determined by a GC and gas volume or simply by difference. The oil was collected either inside the reactor (sometimes the reactor wall was covered with foil liners) or downstream in a number of traps placed in series. Some researchers used a solvent to recover the oil from the reactor and/or downstream traps followed by an evaporation step. Other researchers did not collect the oil, but they directly analyzed the vapors without a condensation step (GC/FTIR/hydrocarbon analyzer). Overall, a wide variety of analysis methods has been 
used to characterize the oil: SEM, GC-MS, GC/MS, SEC, VPO, (FT)IR, UVFS, EA, extraction, video-images, online Infra-red camera and hydrocarbon analyzers.

A unique wire-mesh reactor was used in this study combining the following characteristics: i) high heating rates up to $10.000{ }^{0} \mathrm{C} / \mathrm{s}$ could be achieved ii) the vapor phase was directly cooled using liquid nitrogen iii) the vapors were directly removed from the hot meshes by applying deep vacuum $(<0.3 \mathrm{mbar})$ and the aforementioned cooling iv) all products were captured in a closed system. Although the wire mesh reactor has many attractive features, only small amounts of oil sample were available for further analyses $(<0.05 \mathrm{~g})$, which excluded the use of some analysis techniques (e.g. elemental analysis). 
Chapter 2

Table 2.1 Overview of wire-mesh reactors for pyrolysis of biomass and model compounds ( $\mathrm{TC}=$ Thermocouple, $\mathrm{G}=$ gravimetric, $\mathrm{BD}=$ by difference)

\begin{tabular}{|c|c|c|c|c|c|c|c|c|c|c|c|c|c|c|c|c|c|c|c|c|c|}
\hline 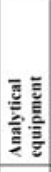 & E & & I্ & & S) & tur & & 资 & 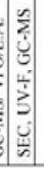 & & 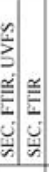 & $\begin{array}{l}\frac{\cong}{\mathscr{n}} \\
\frac{\underline{\underline{\underline{E}}}}{\dot{\delta}} \\
\end{array}$ & | & & $\mid$ & 递 & & & 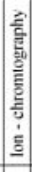 & 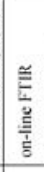 & 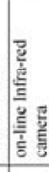 \\
\hline 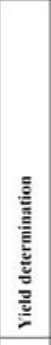 & 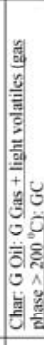 & & 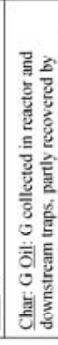 & 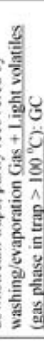 & 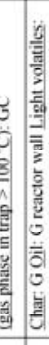 & 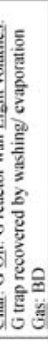 & 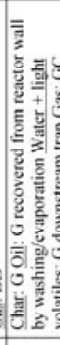 & & & 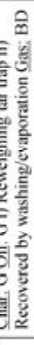 & & $\begin{array}{l}\cong \\
8 \\
8 \\
8\end{array}$ & & & 递焉 & 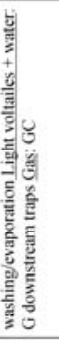 & & & 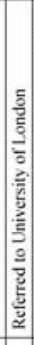 & 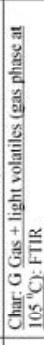 & : \\
\hline$\stackrel{\text { E }}{E}$ & $\stackrel{9}{9}$ & & $\underline{9}$ & & & $\stackrel{9}{9}$ & $\dot{z}$ & 포 & 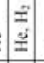 & $\stackrel{9}{9}$ & 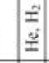 & $\ddot{z}$ & & & & 오 & & & $\cong$ & $\stackrel{9}{1}$ & $\bar{z}$ \\
\hline 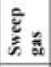 & $\frac{8}{2}$ & & $\stackrel{8}{z}$ & & & z & ż & $\frac{\hat{z}}{e}$ & $\frac{3}{0}$ & $\frac{\hat{\mathrm{E}}}{\hat{\theta}}$ & & $\stackrel{x}{2}$ & 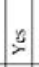 & 8. & 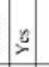 & $\frac{3}{2}$ & 3 & 8. & $\geqslant$ & z & z \\
\hline$\underline{\underline{\underline{\underline{B}}}}$ & II & 8 & $\varrho^{5}$ & & $\frac{?}{6}$ & 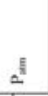 & 2 & 2 & 永 & & & $\stackrel{5}{1}$ & $2^{\frac{\pi}{4}}$ & $a^{1}$ & $a^{\frac{\pi}{4}}$ & $a^{\mathbb{I}}$ & $a^{5}$ & 2 & $a^{5}$ & a & $a^{11}$ \\
\hline 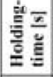 & $\frac{\pi}{\dot{n}}$ & $\begin{array}{l}\stackrel{0}{0} \\
\grave{c} \\
8\end{array}$ & 号。 & . & के. & 0 & के & 8 & 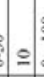 & $\frac{8}{\dot{0}}$ & 의의 & 0 & $\begin{array}{l}< \\
z\end{array}$ & $\underline{1}$ & \begin{tabular}{|l}
$<$ \\
$z$
\end{tabular} & z & $\begin{array}{l}\mathbf{z} \\
\mathbf{z}\end{array}$ & $\underline{n}$ & 今్ & $\stackrel{9}{1}$ & ฉ̊ \\
\hline 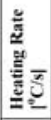 & ఫึ & 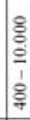 & 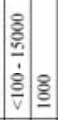 & 8 & 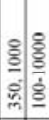 & s. & $\frac{\text { \$్ }}{\frac{8}{3}}$ & 응 & 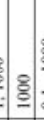 & $\frac{8}{\frac{8}{6}}$ & 웡 & స్ & $\frac{8}{\frac{8}{5}}$ & ః్ & 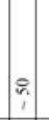 & 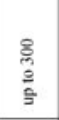 & 8 & \& & \begin{tabular}{l} 
: \\
\hdashline \\
-
\end{tabular} & 兽 & 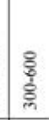 \\
\hline$\Xi$ & 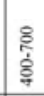 & 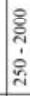 & 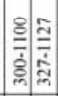 & 学 & $\begin{array}{l}\frac{8}{1} \\
\overline{1} \\
\frac{1}{4}\end{array}$ & 唐 & $\frac{8}{\frac{8}{1}}$ & 辛 & 年 & 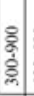 & §ิ & 昙 & 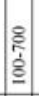 & 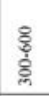 & 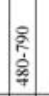 & 店 & 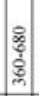 & 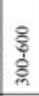 & 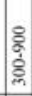 & 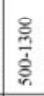 & 总 \\
\hline 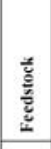 & 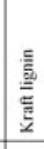 & $\frac{\mathrm{g}}{\frac{3}{3}}$ & 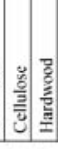 & . & $\frac{b}{\frac{3}{3}}$ & 趃 & 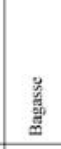 & & 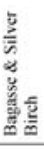 & . & 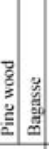 & 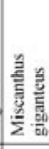 & $\mid$ & 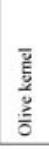 & 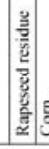 & 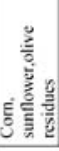 & 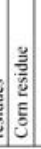 & 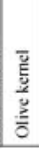 & 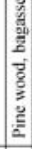 & 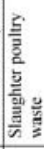 & 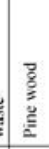 \\
\hline 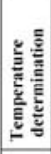 & $\begin{array}{l}< \\
z\end{array}$ & & 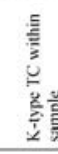 & & & $\cong$ & 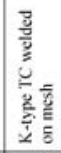 & & 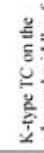 & 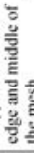 & & 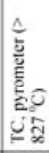 & & & & 冚 & & & - & 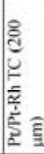 & 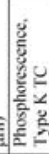 \\
\hline 莫 & 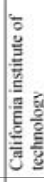 & & 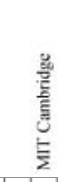 & & & 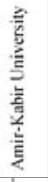 & 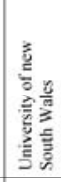 & & & 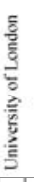 & & 竞 & & & 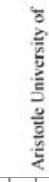 & 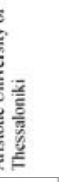 & & & 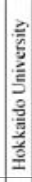 & 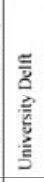 & 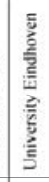 \\
\hline 들 & בे & & $\underline{2}$ & 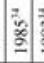 & $\frac{1}{2}$ & 2 & 委 & $\bar{a}$ & 2 & & & స్్ㅀ & 永 & 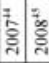 & & \%े & 离 & 8 & 18 & \$్ & శ్ \\
\hline
\end{tabular}




\subsection{Equipment and procedure}

\subsubsection{Feedstock and sample/mesh preparation procedure}

Lignocel 9 (pine, softwood) purchased from Rettenmaier \& Sohne GmbH was used as feedstock. Its chemical composition, elemental composition and ash content are listed in Table 2.2. Lignocel 9 was pre-dried overnight at $105{ }^{\circ} \mathrm{C}$. In a standard experiment, the wood particle size was reduced by using a cutting mill. The sieve fraction retained between aperture sizes of 150 and $250 \mu \mathrm{m}$ was used for the experiments. This milling step was skipped in a few experiments $\left(\mathrm{d}_{\mathrm{p}} \sim 1 \mathrm{~mm}\right)$. A stainless steel 2.5 by $5 \mathrm{~cm}$ wiremesh with an absolute retention of $0.067 \mathrm{~mm}$ was used as reactor material (Dinxperlo, Wire Weaving Co. Ltd., mesh 200, wire thickness $0.06 \cdot 0.06 \mathrm{~mm}$, twilled weave, AISI 316). Approximately $0.05 \mathrm{~g}$ of the sample was carefully spread on one of the meshes to form a (visually) uniform layer. Half a $\mathrm{cm}$ of the mesh on both sides (in length direction) was kept free of biomass as these parts were used to fasten the mesh in between the electrodes. The other mesh was pressed on top of it (press, rodac RQPPS30 30t, 450 $\mathrm{kg} / \mathrm{cm}^{2}$ ). The pressed samples were dried in an oven at $105{ }^{\circ} \mathrm{C}$ again and stored in a desiccator prior to use. The exact amount of Lignocel 9 clamped between the two meshes was determined by reweighing the sample just before the experiment and subsequently subtracting the weight of the empty meshes. A SEM picture with a magnification of 500 times of a typical sample is shown in Figure 2.1.

Table 2.2 Properties of feedstock: Lignocel 9 (pine wood) ${ }^{15}$

\begin{tabular}{|c|c|}
\hline Cellulose $\left[\mathrm{wt} \%_{\mathrm{dry}}\right]$ & 35 \\
\hline Hemicellulose $\left[\mathrm{wt} \%_{\mathrm{dry}}\right]$ & 29 \\
\hline $\operatorname{Lignin}\left[\mathrm{wt} \%_{\mathrm{dry}}\right]$ & 28 \\
\hline ash $\left[\mathrm{wt} \%_{\mathrm{dry}}\right]$ & 0.6 \\
\hline $\mathrm{C}[\mathrm{wt} \%$ dry & 47.6 \\
\hline $\mathrm{H}\left[\mathrm{wt} \%_{\mathrm{dry}}\right]$ & 5.9 \\
\hline $\mathrm{O}\left[\mathrm{wt} \%_{\mathrm{dry}}\right]$ & 46.3 \\
\hline $\mathrm{N}\left[\mathrm{wt} \%_{\text {dry }}\right]$ & 0.2 \\
\hline Water [wt\%] (after drying step) & 0 \\
\hline
\end{tabular}

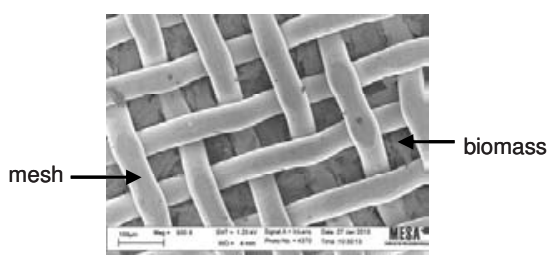

Figure 2.1 Lignocel 9 clamped in wire-meshes (top view)

\subsubsection{Set-up: wire-mesh reactor}

Figure 2.2 shows the front- and side view of the wire-mesh reactor. The numbers mentioned in this paragraph correspond to the numbers in that figure. Typical operating conditions to determine the initial pyrolysis decomposition products are reported in Table 2.3. The set-up consisted of a vessel (1, Duran centrifuge tube round bottom $250 \mathrm{ml}, \mathrm{D}=$ $5 \mathrm{~cm}$ ) containing the mesh/biomass sample (2) in a vacuum atmosphere, an electrical circuit to heat the mesh, a liquid nitrogen bath (4) to cool the vessel wall, a gas sampling 
system (9) and equipment to monitor temperature and pressure. The vessel (1) and the liquid nitrogen bath (4) were constructed from glass. In this way it was possible to follow the course of an experiment visually. A two staged rotary vane vacuum pump (10, Edwards E2M-1.5) was used to create a vacuum atmosphere (final pressure $<0.3$ mbar). A Vacuubrand DCP 3000 pressure sensor $\left(8\right.$, error $_{a b s}=0.07$ mbar) was used to monitor the pressure before and after an experiment. In a few experiments, a fast response pressure sensor (Druck PTX 520) was used to record pressure profiles as function of time. A calibrated infrared pyrometer (12) with a response time of $180 \mu$ s (Kleiber, type KGA $730,160{ }^{0} \mathrm{C}<\mathrm{T}<1000{ }^{0} \mathrm{C}$ ) was used to measure the temperature of the mesh. The pyrometer was inserted into a small glass tube that reached through the nitrogen bath (13), thereby preventing interference from the (boiling) liquid nitrogen on the signal. In some experiments a K-type thermocouple $(\varnothing 1.5 \mathrm{~mm}$ ) was positioned inside the vessel (7) to monitor the surrounding temperature of the mesh.

The two wire meshes served as an electrical resistance heater. Two copper clamps, one of which was connected to a movable spring, were used to hold the meshes. The complete electrical system was designed and built in house and consisted of two separate circuits. One electrical circuit was used to generate the initial heating pulse the other one to supply the heat required during the holding time. The holding time is defined as the period the meshes are maintained at the set-temperature (Figure 2.4). The required power was supplied by two $12 \mathrm{~V}$ batteries connected in series. For the heating pulse these were two Varta Silver Dynamic batteries (12V/100 Ah, $830 \mathrm{~A}$ ) and for the supply of heat during the reaction two Varta Pro Motive batteries (12V/225 Ah/ $1150 \mathrm{~A})$. One temperature independent resistance $\left(15^{\cdot} 10^{-5} \Omega\right.$,) was incorporated in the electrical system. By measuring the voltage drop across this resistance and the voltage drop across the mesh, the current, resistance and power through the mesh could be calculated using Ohm's law. To read the temperatures, pressures and voltages a DAQ card (NI PCI-6281) was used. A Labview program running on a personal computer at a speed of $2000 \mathrm{~Hz}$ was used to store all measured data. The length of the heating pulse and holding time could be set independently in this program. The temperature during the holding time was regulated by a PID controller.

Table 2.3 Standard operating conditions for the determination of initial decomposition products

\begin{tabular}{|l|l|}
\hline $\mathrm{T}\left[{ }^{0} \mathrm{C}\right]$ & $\sim 500$ \\
\hline Heating rate $\left[{ }^{0} \mathrm{C} / \mathrm{s}\right]$ & $\sim 7000$ \\
\hline Feedstock & Pine Wood (Lignocel 9) \\
\hline Biomass loading $[\mathrm{g}]$ & $\sim 0.05$ \\
\hline Holding time $[\mathrm{s}]$ & $1-3$ \\
\hline Initial $\mathrm{P}[\mathrm{mbar}]$ & $<0.3$ \\
\hline
\end{tabular}




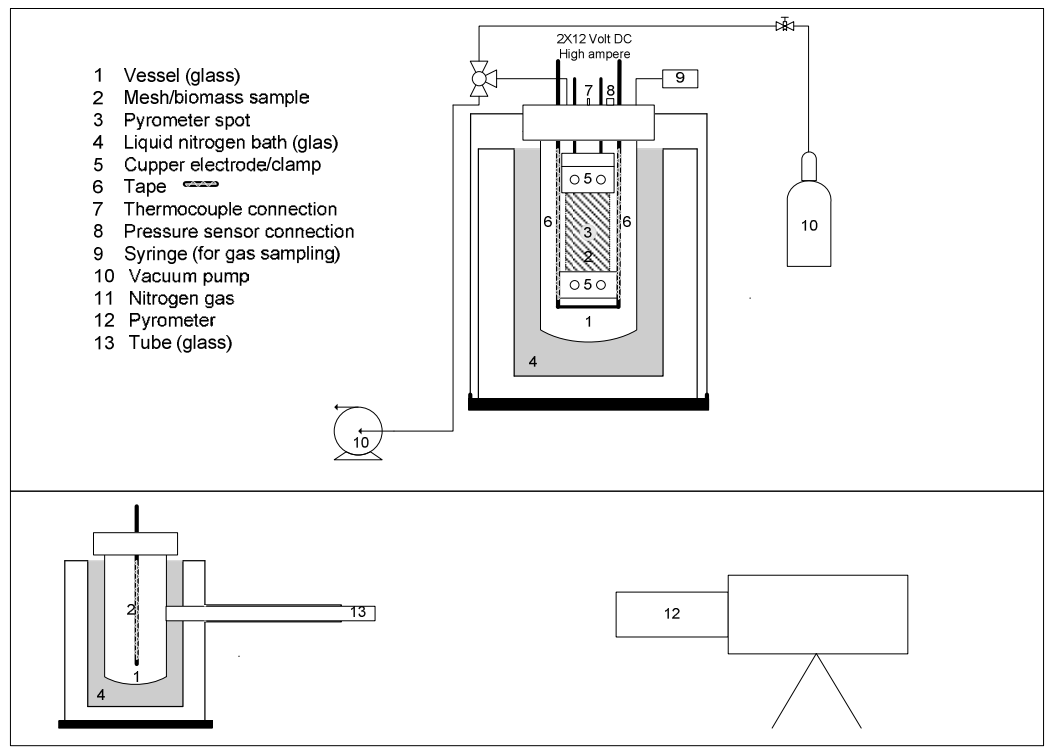

Figure 2.2 Scheme of wire-mesh reactor. Top: front view; Bottom: side view

\subsubsection{Run procedure: wire-mesh reactor}

Prior to each experimental run the wire mesh/biomass sample (2), copper clamps (3), vessel (1) and tape (6) were weighed on an analytical balance (Mettler AE 200, readability $0.1 \mathrm{mg}$ ). Tape was wound around the electrodes to collect the deposited oil on this part of the set-up (typically, less than $10 \mathrm{wt} \%$ of the oil was deposited on the tape and copper clamps). Hereafter, the different parts of the set-up were connected: i) the mesh/biomass sample was inserted between the electrodes using the copper clamps ii) the vessel was placed around the mesh/biomass sample iii) the set-up was placed in the empty nitrogen bath iv) the pyrometer spot (3) was positioned in the middle of the mesh. Air was removed from the vessel by first evacuating the vessel (1), hereafter filling it with gaseous nitrogen and hereafter evacuating again (to $\sim 0.6$ mbar). After this, the bath (4) was filled with liquid nitrogen causing a further reduction in pressure $(<0.3 \mathrm{mbar})$ (4). A few runs were carried out at atmospheric pressure ( $\mathrm{N}_{2}$ atmosphere) and/or without liquid nitrogen. Their conditions are reported in Table 2.4. The run was started after setting a heating pulse, holding time and set-temperature for the PID controller in the Labview program. After the run, the closed vessel including the sample was removed from the liquid nitrogen bath. After reaching room temperature the vessel was filled with nitrogen till 0.8 bar to be able to take a gas sample with a $10 \mathrm{ml}$ syringe (9). Hereafter, the vessel was opened and immediately a stopper was put onto it, to prevent evaporation of the produced pyrolysis oil. The vessel, copper clamps, tape and mesh/char sample were reweighed. For further analysis of the oil, the vessel with the oil was stored in a freezer at $-20{ }^{0} \mathrm{C}$ to prevent aging reactions ${ }^{57}$. 
Chapter 2

Table 2.4 Conditions for experiments carried out at different pressures and vapor temperatures

\begin{tabular}{|l|c|c|c|c|}
\hline Name Experiment & $\begin{array}{c}\text { Initial pressure } \\
{[\mathrm{mbar}]}\end{array}$ & $\begin{array}{c}\text { Holding time } \\
{[\mathrm{s}]}\end{array}$ & Cooling & $\begin{array}{c}\mathrm{T} \\
{\left[{ }^{0} \mathrm{C}\right]}\end{array}$ \\
\hline $\mathrm{P}_{\mathrm{vac}}$ Cooling (standard) & $0.0-0.3$ & $1-3$ & Yes & $500{ }^{0} \mathrm{C}$ \\
\hline $\mathrm{P}_{\mathrm{vac}}$ No Cooling & $0.6-0.9$ & 3 & No & $500{ }^{0} \mathrm{C}$ \\
\hline $\mathrm{P}_{\mathrm{atm}}$ Cooling & 500 & 3 & Yes & $500{ }^{\circ} \mathrm{C}$ \\
\hline $\mathrm{P}_{\mathrm{atm}}$ No Cooling & 1000 & 3 & No & $\begin{array}{c}500{ }^{\circ} \mathrm{C} \\
\text { increasing till } 600{ }^{0} \mathrm{C}\end{array}$ \\
\hline
\end{tabular}

\subsubsection{Analytics}

\section{Pyrolysis oil}

The total amount of oil is defined as the sum of the oil collected on the tape/clamps $(5,6)$ and vessel (1) at room temperature (eq. 1).

Oil yield $[w t \%]=\frac{\left(m_{\text {vessel }+ \text { oil }}-m_{\text {vessel }}\right)+\left(m_{\text {tape } / \text { clamps }+ \text { oil }}-m_{\text {tape } / \text { clamps }}\right)}{\left(m_{\text {meshes }+ \text { biomass }}-m_{\text {meshes }}\right)} \cdot 100 \%$

It is important to realize that at the moment of the determination of the oil yield some volatile compounds like acetic acid and methanol which are known to be present in pyrolysis oil ${ }^{3}$ will partly be vaporized. For example, calculations based on saturation showed that about half of the produced amount of acetic acid would be vaporized under our conditions ( $\mathrm{T}_{\text {room }}, \mathrm{V}=250 \mathrm{ml}$, acetic acid yield assumed to be $5 \mathrm{wt} \%$ ).

Size Exclusion Chromatography (SEC) was used to obtain an indication of the molecular weight distribution of pyrolysis oil (chapter 6)58 (Agilent Technologies 1200 series, RID detector, eluent $1 \mathrm{~mL} / \mathrm{min}$ THF, columns 3 PLgel3 $\mu \mathrm{m}$ MIXED-E placed in series, standard $162-30000 \mathrm{~g} / \mathrm{mol}$ polystyrene). $10 \mathrm{mg}$ of pyrolysis oil was dissolved per $\mathrm{ml}$ of THF. A white THF insoluble, but water soluble fraction was observed for some experiments. This fraction was further analysed by HPLC (Waters Alliance 2695, BioRad column Aminex HPX-87H, $60{ }^{\circ} \mathrm{C}$, RID detector, eluent $0.55 \mathrm{ml} / \mathrm{min} 5 \mathrm{mM}$ sulphuric acid solution; analyses carried out by the University of Groningen). 1-H-NMR (32 scans, deuterated DMSO as solvent $1 \mathrm{ml} / 0.04 \mathrm{~g}, 300 \mathrm{MHz}$ Varian) was used to identify the functional groups in the resulting oils. The classification suggested by Ingram et al. ${ }^{5}$ was used to interpret the H-NMR spectra in terms of functional groups. The DMSO peak (2.54 till $2.55 \mathrm{ppm}$ ) was excluded from data analyses.

\section{$\underline{\text { Gas }}$}

The gas samples (9) were analysed in a gas chromatograph (Varian Micro GC CP-4900 with two analytical columns, $10 \mathrm{~m}$ Molsieve 5A and $10 \mathrm{~m}$ PPQ, using Helium as carrier gas) for $\mathrm{CH}_{4}, \mathrm{CO}, \mathrm{CO}_{2}, \mathrm{C}_{2} \mathrm{H}_{4}, \mathrm{C}_{2} \mathrm{H}_{6}, \mathrm{C}_{3} \mathrm{H}_{6}, \mathrm{C}_{3} \mathrm{H}_{8}$. The sum of $\mathrm{C}_{2} \mathrm{H}_{4}, \mathrm{C}_{2} \mathrm{H}_{6}, \mathrm{C}_{3} \mathrm{H}_{6}$ and $\mathrm{C}_{3} \mathrm{H}_{8}$ will further be referred to as $\mathrm{C}_{2+}$. In several experiments the gas yield was determined 
independently by using the initial and final pressure and then using (eq. 2a). In analogy with the previous section, it should be noted that this pressure difference is not only caused by the permanent gases formed, but also by the vaporization of some volatile compounds from the oil at room temperature. So, the real permanent gas yield is expected to be slightly lower than the reported values in this paper. For the other experiments the gas yield was derived from the mass balance using eq. $2 \mathrm{~b}$.

Gas yield $[w t \%]=\sum_{\substack{i=\mathrm{CO}_{1}, \mathrm{CO}_{2} \\ \mathrm{CH}_{4}, \mathrm{C}_{2+}}} \frac{\frac{\left(\mathrm{P}_{\text {after experiment }}-\mathrm{P}_{\text {before experiment }}\right)}{\mathrm{RT}_{\text {room }}} \cdot v_{\text {vessel }} \cdot \frac{\mathrm{mol} \% \mathrm{i}}{100} \cdot \mathrm{M}_{\mathrm{i}}}{\mathrm{m}_{\text {meshes + biomass }}-\mathrm{m}_{\text {meshes }}} \cdot 100 \%$ (eq.2a) Gas yield $[\mathrm{wt} \%]=100-($ Oil yield + Char yield $)$

$\underline{\text { Char }}$

Char was defined as the material remaining between the meshes after an experiment (thus also incorporating possibly unconverted biomass). 'Complete conversion' is defined as the conversion at the moment when all reactions are finished at a certain temperature; the residue "char" yield does not change anymore. The char was characterized by FTIR (Bruker Tensor 27, $4 \mathrm{~cm}^{-1}, 16$ scans, $4000-550 \mathrm{~cm}^{-1}$ ). Because of the very small sample size of the biomass used in each run, it was necessary to combine char from several experiments (carried out at the same conditions) to provide enough material for FTIR analysis. The char structures were visually analyzed by scanning electron microscopy (HR-SEM ZEISS 1550). The char yield was calculated with eq. 3.

Char yield $[w t \%]=\frac{m_{\text {meshes }+ \text { char }}-m_{\text {meshes }}}{m_{\text {meshes }+ \text { biomass }}-m_{\text {meshes }}} \cdot 100 \%$

\subsubsection{Process visualization}

Digital photos of the mesh during the pyrolysis process were recorded using a $400 \mathrm{~Hz}$ high speed camera (LaVision Imager Pro). DaVis 7.2 software was used to edit and compile movies from the photos to obtain dynamic information about oil layer formation on the vessel wall. The photo made prior to the start of the experiment was substracted as 'background' from all of the following photos to better observe dynamic changes. All background corrected photos have grey levels from black to white. The first background corrected photo was completely black, while greyish pixels were appearing when oil was condensing on the vessel wall. Grey-level histograms were constructed from these background corrected photos: the colour intensity (from black to white) as function of the time was used to (semi)-quantify the dynamic oil layer formation. This technique will be referred to as "grey intensity" in the remainder of the chapter. 


\subsubsection{Pilot plant}

A continuous fluidized bed reactor operated at the University of Twente $(1 \mathrm{~kg} / \mathrm{hr})$ was used to produce a reference oil. Details about the set-up are published elswere ${ }^{\text {(chapter 5)15-17. }}$. The residence time of the vapors was around 1-2 s. The same feedstock as reported in Table 2.2 was used for these experiments, however, in this case, the feedstock was not milled and not dried (particle diameter $1 \mathrm{~mm}$, moisture 5-8 wt\%). This process will be referred to as "pilot plant" in the rest of the chapter. All data are reported on dry basis.

\subsection{Set-up characteristics}

\subsubsection{Mesh/sample temperatures}

\section{Temperature monitoring}

The way the temperature is monitored is a point of attention in the usage of the wiremesh technique. Frequently, a thermocouple (either placed in between the screens or welded on the mesh) is used to measure the mesh temperature ${ }^{14,32,34,36-40,42,43}$. Other methods use the mesh resistance (which changes with temperature ${ }^{41}$ ), a pyrometer ${ }^{41,43}$ or phosphorescence ${ }^{42}$. We applied the first three methods in our set-up and compared them with each other. The K-type thermocouples $(\varnothing 1.5 \mathrm{~mm})$ proved to be slower than the pyrometer and were indicating significantly lower temperatures. The maximum temperature was monitored $2 \mathrm{~s}$ after the end of the heating pulse (no holding time applied) and was about $100{ }^{0} \mathrm{C}$ lower compared to the temperature monitored with the pyrometer at that moment. When only the two inner wires of the thermocouple $(\varnothing 0.24$ $\mathrm{mm})$ were welded on the mesh, the delay $(\sim 300 \mathrm{~ms})$ and temperature difference became smaller $\left(\sim 30{ }^{0} \mathrm{C}\right)$ as compared to the pyrometer but did not disappear. In accordance with our results, Prins et al. ${ }^{42}$ also measured lower temperatures when using thermocouples compared to phosphorescence. They ascribed this to heat losses via the thermocouple. The resistance technique appeared to be unfeasible as well because only an average resistance can be obtained. This average resistance is influenced significantly by the lower local resistances (temperatures) at the extreme borders, thus not giving a good indication of the sample temperature (Figure 2.3). Because of the aforementioned drawbacks of the first two techniques, we have chosen to measure the mesh temperature with a pyrometer. This method is fast (response time $180 \mu \mathrm{s}$ ) and the desired spot position can be chosen (Figure 2.2). The influence of pyrolysis vapors/aerosols on the pyrometer measurement - as mentioned in literature ${ }^{29}$ - was qualitatively studied by blowing some cigar smoke in between a hot mesh at constant temperature and the pyrometer. The smoke did not appear to influence the pyrometer signal until excessive amounts of smoke (not representative for a typical experiment) were used and a drastic decrease in signal strength was observed. 


\section{Temperature distribution}

The temperature distribution over the mesh should preferably be uniform. However previous studies have shown that this is difficult to realize ${ }^{19,42}$. A second pyrometer was installed in addition to the controlling pyrometer (Figure 2.2) to map possible spatial temperature differences over the mesh. The temperature differences after a holding time of $1 \mathrm{~s}$ and with respect to the centre temperature are schematized in Figure 2.3. The temperature distribution obtained without using biomass shows that the borders of the mesh had a temperature which was approximately $50{ }^{\circ} \mathrm{C}$ lower than the centre. Smaller temperature differences were observed directly after the heating pulse $\left(\sim 25^{\circ} \mathrm{C}\right.$; results not shown). The temperature in the centre section of the mesh could be controlled within 20 ${ }^{0} \mathrm{C}$. The temperature deviation caused by a strong non-uniform biomass distribution was determined by carrying out an experiment in which a small centre part of the mesh was covered with biomass, while the rest of the mesh did not contain any biomass. The controlling pyrometer was focused on this centre section. Huge temperature differences of over $+300{ }^{\circ} \mathrm{C}$ were observed in the parts not covered by biomass (Figure 2.3, middle). These fluctuations can be ascribed to the energy needed to heat up the biomass and to the endothermic pyrolysis decomposition reactions ${ }^{59}$. Freihaut and Proscia ${ }^{19}$ observed temperature differences of the same order of magnitude between biomass loaded and unloaded mesh locations. These results clearly show the importance to evenly distribute the biomass sample. Finally, the temperature distribution for samples prepared according to the standard procedure (section 2.3.1) was determined (Figure 2.3, right). Slightly higher temperature fluctuations were observed $\left( \pm 35{ }^{\circ} \mathrm{C}\right)$ than when using the unloaded mesh, but temperature fluctuations were generally modest (it was not possible to monitor temperatures at the extreme edges of the mesh). In literature, slightly lower temperature fluctuations $\left(10{ }^{0} \mathrm{C}^{38}\right.$ till $\left.20{ }^{0} \mathrm{C}^{20}\right)$ are generally reported for wire-mesh reactors at heating rates up to $1000{ }^{\circ} \mathrm{C} / \mathrm{s}$. It should be noted that these differences were typically measured with thermocouples while our results indicate that this technique is relatively slow and less suitable for the determination of the mesh temperature. Besides that, the uniformity of the mesh temperature is reported to decrease markedly with increasing heating rates ${ }^{46}$. Our experiments were carried out with high heating rates, up to $10.000{ }^{\circ} \mathrm{C} / \mathrm{s}$ (section 2.4.1). In conclusion, it can be stated that in our set-up the temperature of the major part of the mesh was controlled within $35^{\circ} \mathrm{C}$. 

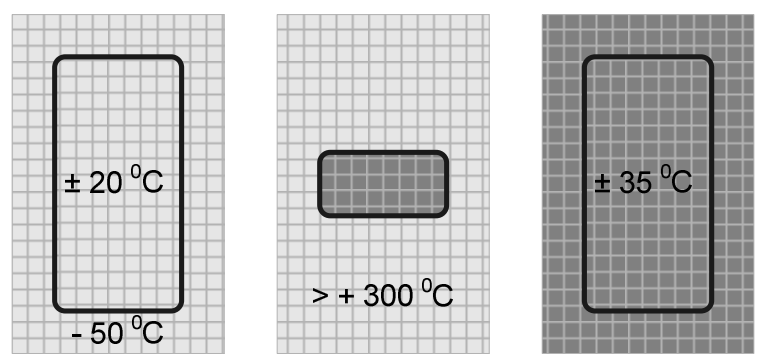

Mesh

Mesh + Biomass

Figure 2.3 Temperature distribution over mesh after a holding time of $1 \mathrm{~s}, \mathrm{~T}_{\text {center }}=500{ }^{\circ} \mathrm{C}$. Numbers indicate difference with center temperature

\section{Temperature profile typical run}

Preferably, experiments need to be carried out isothermally to be sure that the reactions take place essentially at the set-temperature $\left(500{ }^{0} \mathrm{C}\right)$. For this, high heating rates, constant temperatures during sufficient holding time and fast cooling rates are required. In a wire mesh reactor the cooling rate is not important if complete conversion is already achieved during the holding time. A typical temperature profile and the corresponding power delivery of the batteries is plotted in Figure 2.4. A mesh heating rate of $7.0 \bullet 10^{3}$ ${ }^{0} \mathrm{C} / \mathrm{s}$ was achieved using a typical biomass loading of $0.05 \mathrm{~g}$ : Table 2.5 shows that the heating rate of the mesh (and biomass) decreased with biomass loading. A lag in temperature between the biomass sample and the wire-meshes must inevitably occur because of heat transfer resistances from the mesh to the sample and within the sample. Because the biomass was in direct contact with the meshes (Figure 2.1) it is expected that the heat transfer resistance from the mesh to the sample is very small. An indication of the reduction of the average heating rate of the sample due to internal heat transfer resistances was obtained by solving the instationary heat balance for a biomass sample clamped between two meshes (using well known heat penetration theories; see e.g. page 376 in Transport Phenomena ${ }^{60}$ ). The endothermic heat of reaction term was ignored in this calculation as well as the external heat transfer resistances $\left(\mathrm{T}_{\text {mesh }}=\mathrm{T}_{\text {outside biomass layer }}\right)$. Required data for the skeletal density, heat conductivity and heat capacity were taken from Kersten et $\mathrm{al}^{6}$ From this calculation it follows that the average heating rate of the biomass sample was $6.6 \cdot 10^{3} \mathrm{C} / \mathrm{s}$ for a typical biomass loading of $0.05 \mathrm{~g}$. Values for other biomass loadings are reported in Table 2.5. From the data in section 2.4.2, it is proven without any doubt that fast heating rates were achieved. The first pyrolysis products were condensed on the vessel wall within $55 \mathrm{~ms}$. This $55 \mathrm{~ms}$ incorporates the time to heat-up the sample till $200-300{ }^{\circ} \mathrm{C}$, the time to convert (part of) the biomass and the vapor phase residence time.

In Figure 2.4 it can be seen that the temperature remained nearly constant during the holding time. At the measuring spot, the temperature could be regulated within about 5 
${ }^{0} \mathrm{C}(2 \bullet$ stdev) from the temperature reached after the heating pulse. As an exception, it was more difficult to maintain a constant temperature for the few experiments carried out without cooling and at atmospheric pressure (Table 2.4). In that particular case excessive amounts of aerosols were intermittently disturbing the pyrometer signal leading to a final temperature $100{ }^{\circ} \mathrm{C}$ above the set value.

After shutting down the power, the mesh cooled down by radiation (vacuum and atmospheric experiments) and additionally by free convection for the experiments carried out at atmospheric pressure. Under vacuum, it took approximately $5.5 \mathrm{~s}$ for the temperature to drop from $500{ }^{0} \mathrm{C}$ to $300{ }^{\circ} \mathrm{C}$ (Figure 2.4). This time was reduced till about $3.5 \mathrm{~s}$ for the experiments carried out at atmospheric pressure (Table 2.4). This time is significant compared to the total experimental time (1-3 s), however the cooling rate is not important if the conversion is already (near) complete. In section 2.5.4 it is shown that this is indeed the case for experiments carried out at $500{ }^{0} \mathrm{C}$.

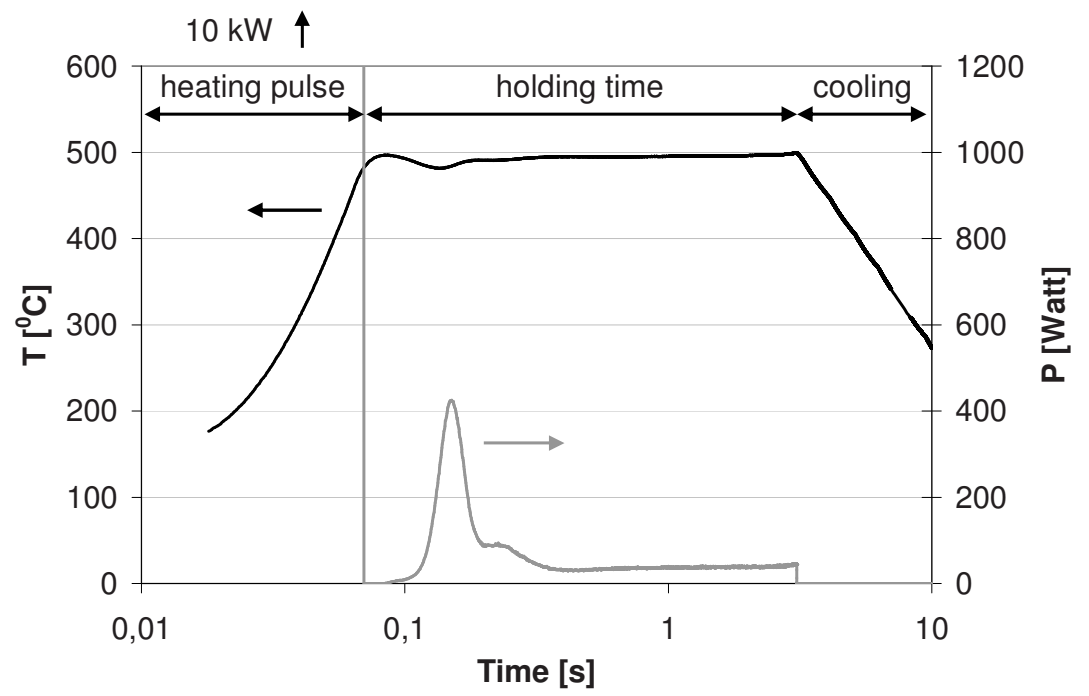

Figure 2.4 Typical mesh temperature and power profile ( $0.05 \mathrm{~g}$ biomass, holding time $3 \mathrm{~s})$

Table 2.5 Estimated heating rate for different biomass loadings. Set temperature $500^{\circ} \mathrm{C}$

\begin{tabular}{|l|l|l|l|}
\hline $\begin{array}{c}\text { Biomass loading } \\
{[\mathrm{g}]}\end{array}$ & \multicolumn{1}{|c|}{$\begin{array}{c}\text { Layer thickness } \\
{[\mu \mathrm{m}]^{*}}\end{array}$} & $\begin{array}{c}\text { Heating rate mesh } \\
{\left[{ }^{0} \mathrm{C} / \mathrm{s}\right]^{* *}}\end{array}$ & $\begin{array}{c}\text { Average heating rate } \\
\text { biomass sample }^{* * * *}\end{array}$ \\
\hline 0.00 & 0 & $1.0 \bullet 10^{4}$ & --- \\
\hline 0.05 & 45 & $7.0 \bullet 10^{3}$ & $6.6 \bullet 10^{3}$ \\
\hline 0.08 & 78 & $6.7 \bullet 10^{3}$ & $5.3 \bullet 10^{3}$ \\
\hline 0.100 & 92 & $6.5 \bullet 10^{3}$ & $4.6 \bullet 10^{3}$ \\
\hline
\end{tabular}




\subsubsection{Vapor residence time and temperature}

Vapor temperature $^{2}$ and pressure ${ }^{14}$ are thought to be important factors, influencing the escape velocity (vaporization/sublimation/physical entrainment) of vapors, gases and aerosols out of the (decomposing) biomass particles and the extent of vapor cracking and polymerization reactions. The standard experiments were performed in vacuum and the reactor was placed in a liquid nitrogen bath (Figure 2.2). A few experiments were carried out at atmospheric pressure both with and without liquid nitrogen cooling (Table 2.4, section 2.6).

To measure the vapor/gas phase temperature surrounding the meshes two thermocouples were inserted in the gas phase of the reactor (Figure 2.2) for the following situations: $\mathrm{P}_{\text {vac }} /$ Cooling, $\mathrm{P}_{\text {vac }} /$ No Cooling, $\mathrm{P}_{\mathrm{atm}} /$ Cooling and $\mathrm{P}_{\mathrm{atm}} /$ No Cooling (Table 2.4). One thermocouple was positioned within a $1 \mathrm{~cm}$ distance of the mesh (but not attached to it) and one close to the reactor wall $(\sim 0.5 \mathrm{~cm})$. The maximum measured temperatures with and without biomass loading are listed in Table 2.6. If the meshes were loaded with biomass, the maximum measured temperature in close vicinity of the mesh was over 70 ${ }^{0} \mathrm{C}$. This temperature rose to even $300{ }^{0} \mathrm{C}$ for the experiment carried out under atmospheric pressure without cooling. This rise in temperature must be caused for a large part by the hot pyrolysis vapors/aerosols/gases since the temperature was not exceeding 0 ${ }^{0} \mathrm{C}$ for experiments in which no biomass was clamped in between the meshes and cooling was applied (Table 2.6). The temperature close the wall was extremely low $\left(<-80{ }^{0} \mathrm{C}\right)$ when applying liquid nitrogen cooling. These data show that the vapors, gases and aerosols were quickly cooled under the standard conditions: $\mathrm{P}_{\mathrm{vac}} /$ Cooling (and also $\mathrm{P}_{\mathrm{atm}} /$ Cooling).

Table 2.6 Maximum vapor phase temperatures

\begin{tabular}{|l|c|c|c|c|}
\hline \multirow{2}{*}{ Name Experiment } & \multicolumn{2}{|c|}{ Within $1 \mathrm{~cm}$ distance of the mesh } & \multicolumn{2}{c|}{ Within $0.5 \mathrm{~cm}$ of the wall } \\
\cline { 2 - 5 } & No Wood & Wood $(0.05 \mathrm{~g})$ & No Wood & Wood $(0.05 \mathrm{~g})$ \\
\hline $\mathrm{P}_{\text {vac }}$ Cooling (standard) & $-20{ }^{\circ} \mathrm{C}$ & $90{ }^{\circ} \mathrm{C}$ & $<-80{ }^{\circ} \mathrm{C}$ & $<-80{ }^{\circ} \mathrm{C}$ \\
\hline $\mathrm{P}_{\text {vac }}$ No Cooling & $130{ }^{\circ} \mathrm{C}$ & $150{ }^{\circ} \mathrm{C}$ & $40{ }^{\circ} \mathrm{C}$ & $50{ }^{\circ} \mathrm{C}$ \\
\hline $\mathrm{P}_{\text {atm }}$ Cooling & $-70{ }^{\circ} \mathrm{C}$ & $70{ }^{\circ} \mathrm{C}$ & $<-80{ }^{\circ} \mathrm{C}$ & $<-80{ }^{\circ} \mathrm{C}$ \\
\hline $\mathrm{P}_{\mathrm{atm}}$ No Cooling & $40{ }^{\circ} \mathrm{C}$ & $300{ }^{\circ} \mathrm{C}$ & $30{ }^{\circ} \mathrm{C}$ & $40{ }^{\circ} \mathrm{C}$ \\
\hline
\end{tabular}

A photo was made every $2.5 \mathrm{~ms}$ after the start of the experiments to be able to get an indication about the heating rate (section 2.4.1), reaction time and vapor residence time (defined as time for vapor to travel from mesh to wall). The photos made after $0.3 \mathrm{~s}$ are shown in Figure 2.5. Complete movies of the first second of the experiments are shown on the TCCB website (http://www.utwente.nl/tnw/tccb/publications/video_hoekstra/). Freely circulating aerosols were observed for the experiments at atmospheric pressure; this reduced for $\left(\mathrm{P}_{\mathrm{vac}} / \mathrm{No}\right.$ Cooling) while it was completely absent for $\left(\mathrm{P}_{\mathrm{vac}} /\right.$ Cooling). Our photos/movies suggest that very short reaction and vapor residence times were achieved 
using $\mathrm{P}_{\mathrm{vac}} /$ Cooling. An estimation of this time was made by the "grey intensity" method described in section 2.3.5. The black intensity is given as function of time in Figure 2.6. A sudden decrease in the graph is observed around $55 \mathrm{~ms}$. This shows that the first vapors were already formed and condensed on the reactor wall before the end of the heating pulse $(70 \mathrm{~ms})$. In literature it is well known that the actual degradation of pine wood already begins at temperatures around $200-300{ }^{0} \mathrm{C}^{61,62}$, a temperature that is reached in our set up after 30-40 ms (See Figure 2.8, neglecting internal and external heat transfer limitations).Taking into account that the change in pixel colour at $55 \mathrm{~ms}$ is caused by the first deposition of the products formed at $200-300{ }^{\circ} \mathrm{C}$ then the vapor residence ('travel') time becomes only 15-25 ms.
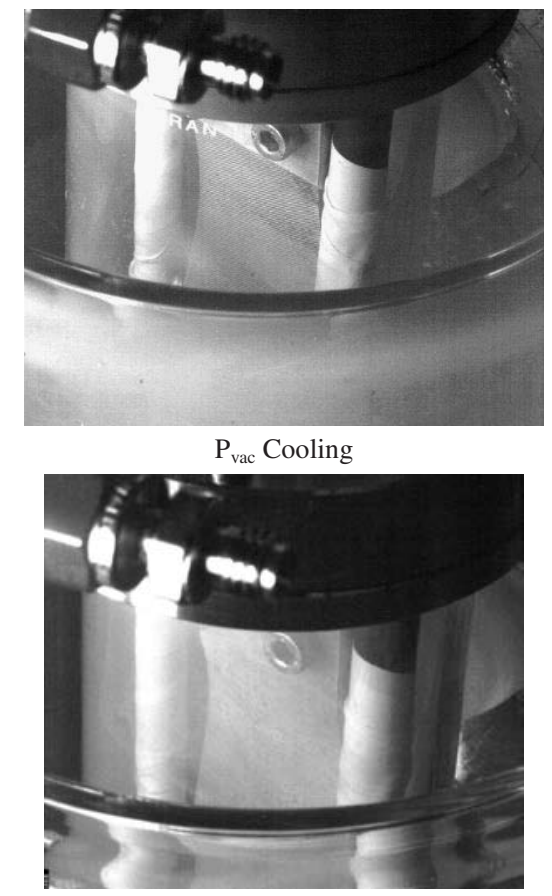

$$
\mathrm{P}_{\text {vac }} \text { No Cooling }
$$

Figure 2.5 Photo's after $0.3 \mathrm{~s}$

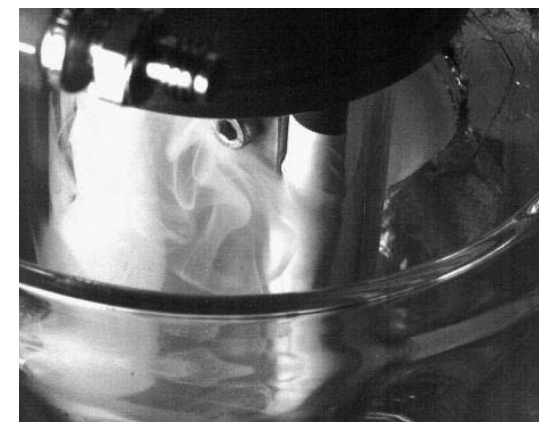

$\mathrm{P}_{\mathrm{atm}}$ Cooling

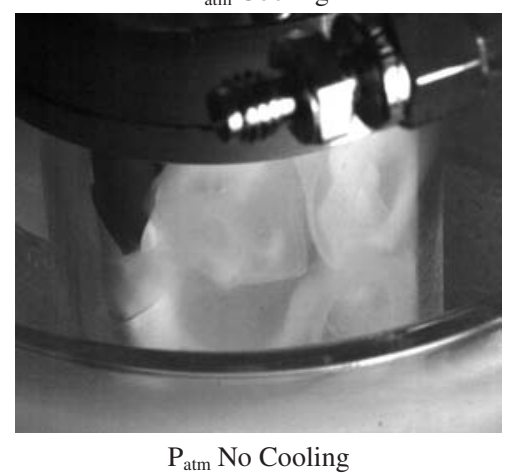

$\mathrm{P}_{\text {atm }}$ No Cooling 


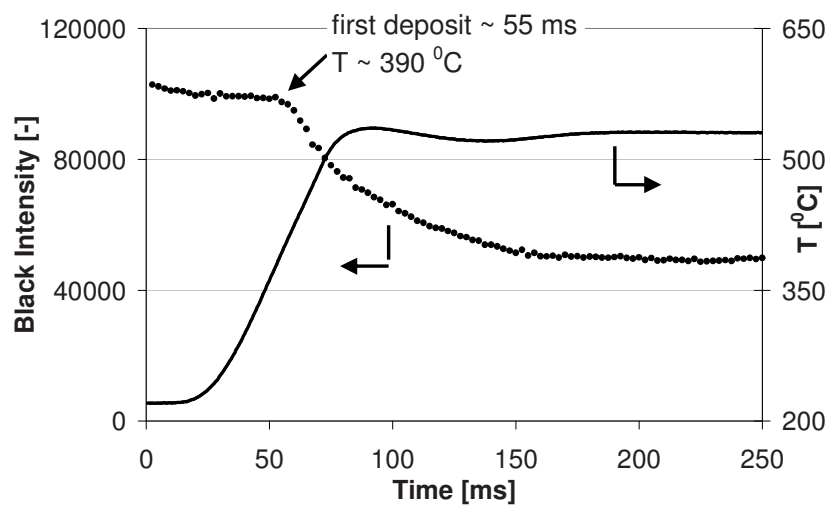

Figure 2.6 Results from "grey intensity" method (section 23.5 ) for determination vapor residence time; pyrometer starts monitoring at $200{ }^{\circ} \mathrm{C}$.

\subsubsection{Reliability and reproducibility}

To determine the reproducibility of the yields and analytical techniques, experiments were carried out 24 times under similar conditions by four different researchers over a 2 years time period. The results are shown in Table 2.7. The oil and char yield had a standard deviation (stdev) of $5 \mathrm{wt} \%$ and $1 \mathrm{wt} \%$ respectively. The inaccuracy in determining the oil yield was mainly caused by weighing errors. The required number of identical experiments whose average should represent a good estimate of the mean value can be calculated by applying statistical analysis on the 24 experimental results ${ }^{63}$. Table 2.8 shows the number of experiments necessary to guarantee, for a confidence interval (CI) of 90, a mean value with an absolute error of \pm 1 till $5 \mathrm{wt} \%$. In this study and in most cases, at least four identical measurements were carried out.

An accurate vacuum pressure sensor was incorporated in a few experiments to separately measure the gas yield (eq. 2a) and to determine the total mass balance closure. Mass balance closures between 90 and $110 \mathrm{wt} \%$ were obtained in these cases. In case char would have fallen through the holes in the mesh, this would result in an overprediction of the oil and underprediction of the char yield. Microscopic photos of the oil (magnification $20 \mathrm{X}$ ) indicated that about $0.4 \%$ of the area could be classified as 'non liquid' and thus possibly as char. Assuming this area\% to equal to the volumetric char\% and taking into account density differences between oil and char, this would correspond to only $\sim 0.04$ wt $\%$ on yield basis. This will not affect the oil and char yields. 
Table 2.7 Reproducibility (0.05 g biomass, T 500 ${ }^{\circ} \mathrm{C}$, holding time $1-3 \mathrm{~s}$ )

\begin{tabular}{|c|c|c|c|c|c|}
\hline \multicolumn{2}{|c|}{$x_{2}^{2}$} & $\mathrm{n}[-]$ & Holding time [s] & Value & stdev \\
\hline \multicolumn{2}{|c|}{ Oil yield [wt\%] (eq. 1) } & 24 & $1-3$ & 84 & 5.1 \\
\hline \multicolumn{2}{|c|}{ Char Yield [wt\%] (eq. 3) } & 24 & $1-3$ & 5 & 1.4 \\
\hline \multicolumn{2}{|c|}{ Gas Yield [wt\%] (by difference eq 2b) } & 24 & $1-3$ & 11 & 5.0 \\
\hline \multicolumn{2}{|c|}{ Gas Yield [wt\%] (measured eq2a) } & 10 & 1 & 8 & 1.0 \\
\hline \multirow{2}{*}{$\begin{array}{l}\mathrm{SEC}^{1}[\mathrm{~g} / \mathrm{mol}] \\
\text { (oil) }\end{array}$} & $\mathrm{M}_{\mathrm{n}}$ & 5 & 0 & 292 & 6 \\
\hline & $\mathrm{M}_{\mathrm{w}}$ & 5 & 0 & 456 & 11 \\
\hline \multirow{4}{*}{$\begin{array}{l}\mathrm{GC}[\mathrm{mol} \%] \\
\text { (gas) }\end{array}$} & $\mathrm{CH}_{4}$ & 10 & 1 & 6.0 & 0.7 \\
\hline & $\mathrm{CO}$ & 10 & 1 & 46.0 & 1.7 \\
\hline & $\mathrm{CO}_{2}$ & 10 & 1 & 46.6 & 2.0 \\
\hline & $\mathrm{C}_{2+}$ & 10 & 1 & 1.4 & 0.3 \\
\hline \multirow{8}{*}{$\begin{array}{l}\text { H-NMR [area\%] } \\
\text { (oil) }\end{array}$} & $10.0-8.0$ & 5 & 3 & 1.2 & 0.3 \\
\hline & $8.0-6.8$ & 5 & 3 & 3.0 & 0.5 \\
\hline & $6.8-6.4$ & 5 & 3 & 3.5 & 0.3 \\
\hline & $6.4-4.2$ & 5 & 3 & 17.0 & 1.7 \\
\hline & $4.2-3.0$ & 5 & 3 & 63.1 & 1.7 \\
\hline & $3.0-2.2$ & 5 & 3 & 5.7 & 1.8 \\
\hline & $2.2-1.6$ & 5 & 3 & 4.1 & 0.7 \\
\hline & $1.6-0.0$ & 5 & 3 & 2.4 & 0.6 \\
\hline \multicolumn{2}{|l|}{$\begin{array}{l}\text { FTIR } \\
\text { (char) }\end{array}$} & 9 & 1 & \multicolumn{2}{|c|}{$\begin{array}{l}\text { Intensity of peaks not } \\
\text { reproducible. Peaks appear } \\
\text { on the same position }\end{array}$} \\
\hline
\end{tabular}

Table 2.8 Number of runs necessary to guarantee for a CI level of $90 \%$ mean values with an absolute error of $+/-1.5 \mathrm{wt} \%$ points

\begin{tabular}{|l|c|c|c|c|c|}
\hline & $+/-1 \mathrm{wt} \%$ & $+/-1.5 \mathrm{wt} \%$ & $+/-2.5 \mathrm{wt} \%$ & $+/-4 \mathrm{wt} \%$ & $+/-5 \mathrm{wt} \%$ \\
\hline $\mathrm{n}$ Gas [-] (eq. 2b) & $\sim 75$ & $\sim 30$ & 12 & 5 & 3 \\
\hline n Oil [-] & $\sim 75$ & $\sim 30$ & 12 & 5 & 3 \\
\hline n Char [-] & 3 & 2 & 1 & 1 & 1 \\
\hline
\end{tabular}

\subsection{Initial decomposition processes under different operating conditions}

\subsubsection{Influence mesh material (AISI 316)}

The wire meshes were made of stainless steel (AISI 316). This material contains primarily iron but also significant amounts of nickel (10-13 wt\%), chromium (16.5-18.5 $\mathrm{wt} \%)$ and molybdenum $(2-2.5 \mathrm{wt} \%)^{64}$. Catalytic effects of these compounds in more "conventional" pyrolysis set-ups in which secondary reactions occur are reported in literature ${ }^{65}$. The role of the mesh material was studied by performing two experiments using meshes on which a layer of gold was vacuum deposited. The purpose of this coating was to avoid direct contact of the solid (decomposing) biomass sample and volatiles with the aforementioned metals. Gold is expected to be inert, but even if gold 
would have a catalytic effect on the pyrolysis reactions, it would be unlikely that this effect is exactly the same as from stainless steel. Operating conditions for this validation test were the standard conditions $\left(\mathrm{T} \sim 500{ }^{\circ} \mathrm{C}\right.$, holding time $\left.1 \mathrm{~s}\right)$ and the results are reported in Table 2.9. The yields obtained using the coated and uncoated meshes were similar within the $90 \%$ confidence interval. In line with these results, similar gas composition and molecular weight distribution (no data reported) were obtained. Therefore any possible catalytic effect of the mesh material appeared to be negligible, which is in line with previous results obtained using a wire mesh reactor ${ }^{24,32}$.

Table 2.9 Influence of mesh material and particle size $\left(\mathrm{T}=500{ }^{\circ} \mathrm{C}\right.$. holding time $1 \mathrm{~s}$, biomass loading $0.05 \mathrm{~g}$, $\mathrm{d}_{\mathrm{p}}=150-250 \mu \mathrm{m}$

\begin{tabular}{|l|c|c|c|c|c|c|c|c|}
\hline & $\begin{array}{c}\mathrm{n} \\
{[-]}\end{array}$ & $\begin{array}{c}\text { oil yield } \\
{[\mathrm{wt} \%]^{\text {ii }}}\end{array}$ & $\begin{array}{c}\text { char yield } \\
{[\mathrm{wt} \%]^{\mathrm{ii}}}\end{array}$ & $\begin{array}{c}\text { gas yield } \\
{[\mathrm{wt} \%]^{\mathrm{iii}, \mathrm{iv}}}\end{array}$ & $\begin{array}{c}\mathrm{CH}_{4} \\
{[\mathrm{vol} \%]^{\mathrm{iv}}}\end{array}$ & $\begin{array}{c}\mathrm{CO} \\
{[\mathrm{vol} \%]^{\mathrm{iv}}}\end{array}$ & $\begin{array}{c}\mathrm{CO}_{2} \\
{[\mathrm{vol} \%]^{\text {iv }}}\end{array}$ & $\begin{array}{c}\mathrm{C}_{2+} \\
{[\mathrm{vol} \%]^{\text {iv }}}\end{array}$ \\
\hline Standard experiment ${ }^{\mathrm{i}}$ & $24 / 10$ & $84 \pm 1.8$ & $5 \pm 0.4$ & 8 & 6,0 & 46,0 & 46,7 & 1,7 \\
\hline Gold sputtered meshes & 2 & $80 \pm 6.2$ & $6 \pm 1.2$ & 9 & 6,5 & 46,5 & 45,8 & 1,3 \\
\hline Particle size $\sim 1 \mathrm{~mm}$ & 5 & $82 \pm 3.9$ & $8 \pm 0.8$ & 7 & 6,3 & 44,4 & 48,0 & 1,3 \\
\hline
\end{tabular}

data from Table $2.7^{\mathrm{ii}}$ width for a CI level of $90 \%{ }^{\mathrm{iii}}$ eq $2 \mathrm{a}^{\mathrm{iv}}$ see Table 2.7 for stdev

\subsubsection{Biomass loading}

To study the effect of biomass loading, experiments were performed at $500{ }^{\circ} \mathrm{C}$ and biomass loadings of 0.05, 0.08 and 0.1 gram. Carrying out experiments at higher biomass loadings has two advantages: more product is available for analyses and the yields can be determined more accurately. On the other hand, the use of higher biomass loadings can result in i) lower heating rates (Table 2.5) and ii) intra layer char/ash induced vapor reactions. This might result in lower oil yields and changes in its composition ${ }^{4,66,67}$. The yields obtained using different biomass loadings are reported in Figure 2.7A, and indicate a decrease in oil yield and an nearly similar increase in gas yield $(\sim 10 \mathrm{wt} \%)$ with biomass loading. For the gas composition a clear trend can be observed (Figure 2.7B): with an increase in biomass loading, the produced gases contained higher concentrations of $\mathrm{CH}_{4}$, $\mathrm{CO}$ and $\mathrm{C}_{2+}$ at the expense of $\mathrm{CO}_{2}$. The gas yields of the individual compounds were estimated using the gas composition and the gas yield trend lines (least square method) from Figure 2.7A and B. The data are reported in Figure 2.7C. Taking into account the measurement errors, the $\mathrm{CO}_{2}$ yield seems to remain fairly constant with increasing biomass loading, while $\mathrm{CH}_{4}, \mathrm{C}_{2+}$ but especially $\mathrm{CO}$ yields increase. The molecular weight distribution of the three oils was similar (no data reported), while the NMR data showed some marginal differences in the oil composition (Table 2.10). For example, for higher biomass loadings more aromatics (10-6.8 ppm) and less water, ether and $=\mathrm{CHO}$ compounds (4.2-3.0 ppm) were observed. These results suggest that although the absolute biomass mass used in these experiments was very small, the results were to some extent still influenced, especially between 0.08 and $0.1 \mathrm{~g}$, by intra-layer vapor reactions and/or slower heating rate with increasing biomass loading. It is well known that ${ }^{68}$ slow heating 
rates results in high char yields. Since an average heating rate of the biomass sample of $4.6 \cdot 10^{3}{ }^{0} \mathrm{C} / \mathrm{s}$ (Table 2.5) is still high and no significant effect of biomass loading on the char yield was observed, the results at higher biomass loadings are likely to be influenced by intra-layer vapor reactions.

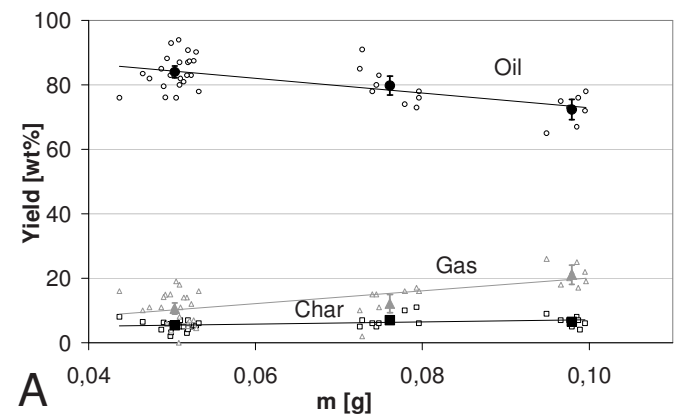

A) Oil, char and gas (eq. 2b) yields

Small open symbols: individual experiments, Large closed symbols: average values including width for a CI level of $90 \%$ Trendlines: method of least squares

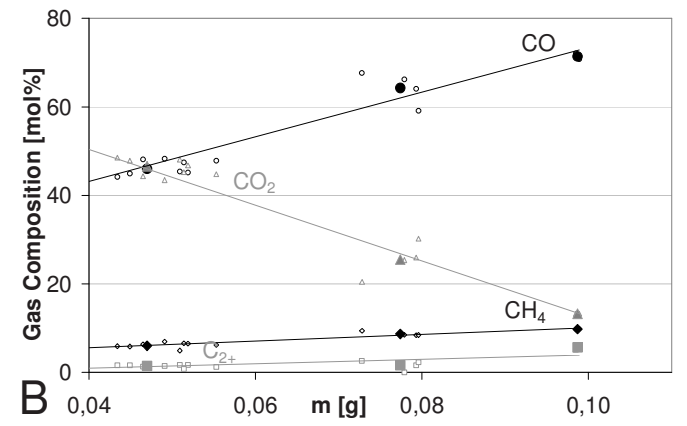

B) Gas composition

Small open symbols: individual, experiments, large closed symbols: average values, Trendlines: method of least squares

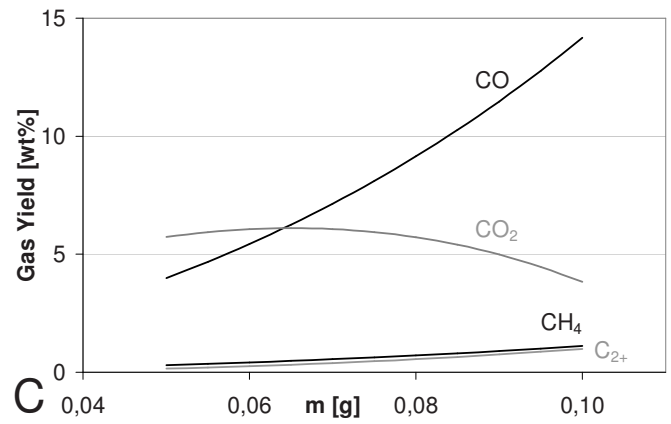

C) Gas yield

Calculated based on trend lines graph A and B

Figure 2.7 Effect biomass loading 
Table 2.10 NMR Results: effect biomass loading ( $\mathrm{T}=500{ }^{\circ} \mathrm{C}$, holding time 1-3 s)

\begin{tabular}{|c|c|c|c|c|}
\hline ppm & Functional Groups & $0.1 \mathrm{~g}$ & $0.08 \mathrm{~g}$ & $0.05 \mathrm{~g}$ \\
\hline $10.0-8.0$ & $-\mathrm{CHO}-\mathrm{COOH}$ downfield $\mathrm{ArH}$ & 3.0 & 2.0 & 1.2 \\
\hline $8.0-6.8$ & ArHHC=C (conjugated) & 4.7 & 4.1 & 3.0 \\
\hline $6.8-6.4$ & $\mathrm{HC}=\mathrm{C}$ (non conjugated) & 4.5 & 4.0 & 3.5 \\
\hline $6.4-4.2$ & ; $\mathrm{CHO} \mathrm{ArOH} \mathrm{HC}=\mathrm{C}$ (non conjugated) & 21.7 & 17.9 & 17.0 \\
\hline $4.2-3.0$ & $\mathrm{H} 2 \mathrm{O}, \mathrm{CH}_{3} \mathrm{O}--\mathrm{CH}_{2} \mathrm{O}-{ }^{-} \mathrm{CHO}$ & 53.4 & 58.5 & 63.1 \\
\hline $3.0-2.2$ & $\stackrel{\stackrel{\mathrm{O}}{\mathrm{CH}_{3}}}{\dot{\mathrm{C}}-\mathrm{CH}_{3} \mathrm{Ar}-\mathrm{CH}_{2} \mathrm{Ar}}$ & 4.5 & 4.8 & 5.7 \\
\hline $2.2-1.6$ & $-\mathrm{CH}_{2}-$ aliphatic $\mathrm{OH}$ & 5.2 & 5.3 & 4.1 \\
\hline $1.6-0.0$ & $-\mathrm{CH}_{3}-\mathrm{CH}_{2}-$ & 3.0 & 3.5 & 2.4 \\
\hline
\end{tabular}

\subsubsection{Effect particle size and milling}

In a standard experiment, the biomass particle size was reduced till about $200 \mu \mathrm{m}$ by using a cutting mill (section 2.3.1). This means that relatively small particles were used compared to more conventional pyrolysis processes. For example, in fluidized bed reactors particles up to $2 \mathrm{~mm}$ are typically used ${ }^{4}$. In 2005 , Kersten et al $^{6}$ stated that no significant influence of the particle size on the yields in the $44 \mu \mathrm{m}-2 \mathrm{~mm}$ range was reported in literature. More recently, Shen and $\mathrm{Wang}^{67}$ did show that higher oil yields were obtained when decreasing the particle size from $1.5 \mathrm{~mm}$ till $300 \mu \mathrm{m}$. They explained this observation by the higher heating rates of the smaller particles, but besides that they speculated about possible changes in cell structure during the milling process.

We carried out 5 experiments using the dried but non-milled particles $\left(\mathrm{d}_{\mathrm{p}} \sim 1 \mathrm{~mm}\right)$ and using otherwise standard conditions $\left(500{ }^{\circ} \mathrm{C} ; 0.05 \mathrm{~g}\right.$ loading and a holding time of $\left.1 \mathrm{~s}\right)$. It should be noted that the wood particles are pressed during the sample preparation procedure (section 2.3.1); the Lignocel 9 layer thickness for the milled and non-milled samples was similar. In Table 2.9, it can be seen that the char yield was higher for the unmilled particles $(+3 \mathrm{wt} \%)$. Although the layer thicknesses were comparable, there are differences on the micro structural level. Intra-particle contact between freshly formed pyrolysis vapors ${ }^{66}$, liquid pyrolysis products ${ }^{69}$ and char/ash particles might lead to an increase in polymerization reactions.

\subsubsection{Holding time}

Reactions can in principle take place during the heating, holding and cooling period (Figure 2.4). In literature, several results obtained without a holding time are reported ${ }^{26-}$ $28,34,39,40$ It is likely that these results must have been influenced by reactions taken place during the heating but probably also during the cooling period. For example, the observation of Nik-Azar et al. ${ }^{40}$ that the oil yield increases as the heating rate decreases 
(no holding period applied) can be ascribed also to the fact that more time is available for sample conversion because the time needed to reach the set temperature increases. In our study, experiments were carried out at $500{ }^{\circ} \mathrm{C}$ with holding times that were varied between 0 and $3 \mathrm{~s}$ to determine the minimally required holding time for complete conversion. Figure 2.8A and B shows that no large influence of holding time on yields was observed, although the results for the experiments carried out without any holding time deviate slightly. Higher char and slightly lower oil yields were observed in that case. The gas produced in the experiments with zero holding time contained a higher content of $\mathrm{CO}_{2}$ and less $\mathrm{CO}$ and $\mathrm{CH}_{4}$ than the gas produced at longer holding times. FTIR analysis of the char indicated that its structure still changed with holding time up to $1 \mathrm{~s}$ (Figure $2.8 \mathrm{C})$. This change is especially noticeable by looking at the peak around $3600-3000 \mathrm{~cm}^{-1}$ $(\mathrm{v}(\mathrm{O}-\mathrm{H}))$ and $1020 \mathrm{~cm}^{-1}(\mathrm{v}(\mathrm{C}-\mathrm{O}))$. No change in overall oil composition with holding time was observed using SEC and NMR analyses (no data reported).

From the data reported in Figure 2.8, it cannot be unambiguously concluded that the conversion is complete within the holding time if a holding time larger than $1 \mathrm{~s}$ is applied. Two other methods were used to quantify the reaction time by following the conversion during the course of an experiment.

1. Following the pressure change in time. For this a fast pressure sensor was used (no absolute pressure data could be obtained).

2. Following the amount of condensate on the vessel wall in time. To semi-quantify this, the "grey intensity" technique as described in section 2.3.5 was used. 


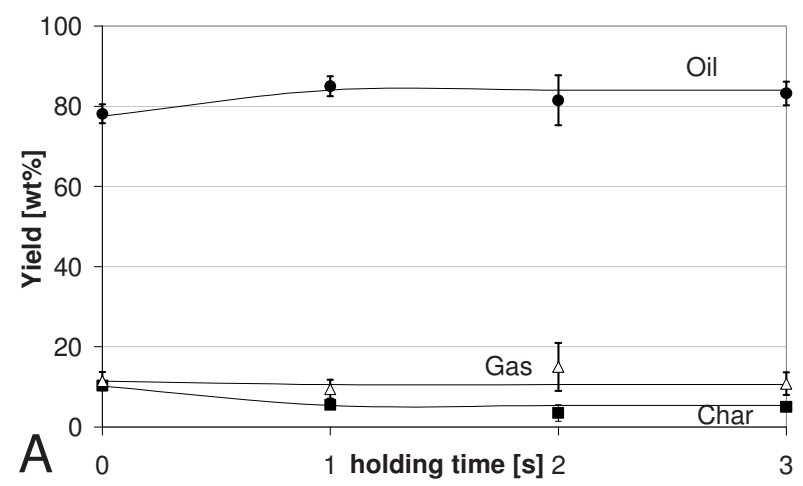

A) Average oil, char and gas (eq. 2b) yields based on 14, 13, 2, 9 experiments including width for a CI level of $90 \%$

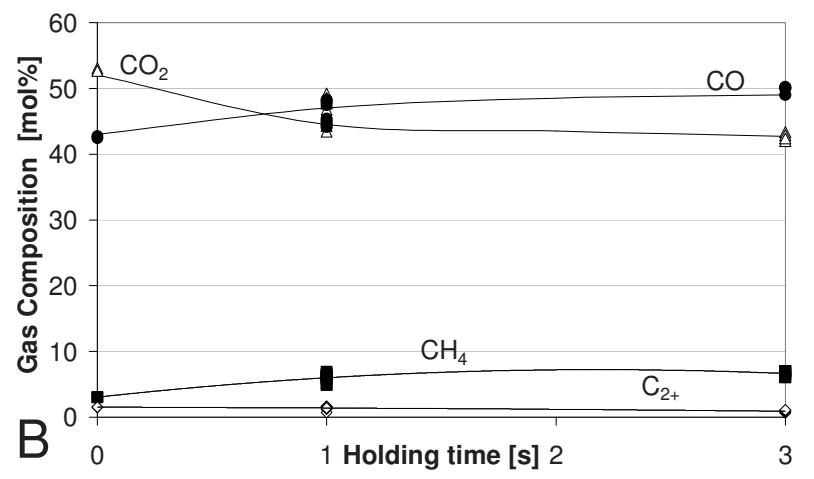

B) Gas composition

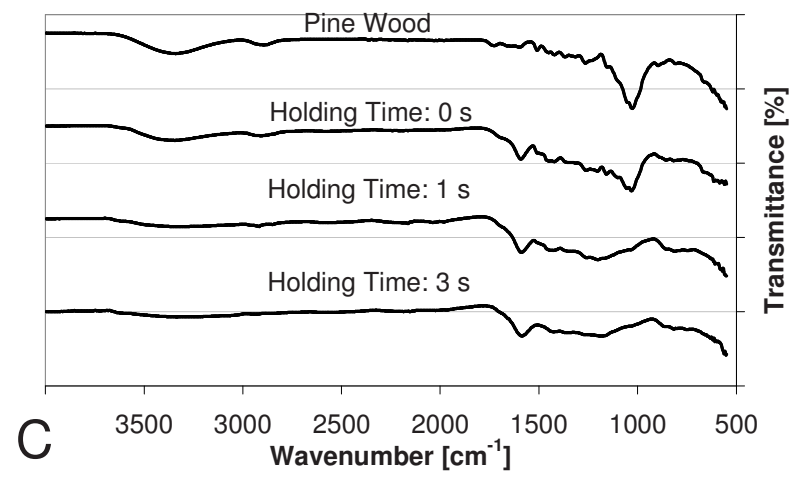

C) FTIR spectra from char samples

Figure 2.8 Effect of holding time 
Figure 2.9 shows that both the pressure and condensate layer were not changing anymore after about $0.8 \mathrm{~s}$ with the majority of the changes even within $0.5 \mathrm{~s}$. Together with the reported data in Figure 2.8 these results show that in our set-up and for typical pyrolysis temperatures of $500{ }^{0} \mathrm{C}$ the reactions are finished within $0.8 \mathrm{~s}$. A holding time of $1 \mathrm{~s}$ is thus sufficient to achieve complete conversion in the current experiments and the cooling rate cannot affect the results anymore.

The observed conversion rate in our wire-mesh reactor is extremely fast compared to literature data. Kersten et $\mathrm{al}^{6}$ compared several kinetic expressions reported in literature with each other. They found a large spread on the data that were ascribed, among others, to widely varying heat and mass transfer characteristics. According to Kersten et $\mathrm{al}^{6}$, Di Blasi and Branca $^{8}$ so far have reported the fastest conversion rate and Thurner and Mann $^{70}$ the slowest. Using the kinetic expression of Di Blasi and Branca and our experimentally applied heating rate, a conversion of only $66.6 \mathrm{wt} \%$ ( 0.6 and $66 \%$ during the heating period and $0.8 \mathrm{~s}$ holding time respectively) would be obtained. Using the kinetic expressions reported by Thurner and Mann ${ }^{70}$ resulted in a conversion of only 12.1 $\%$ ( 0.09 and $12 \%$ during the heating period and $0.8 \mathrm{~s}$ holding time respectively). In our wire mesh reactor the pyrolysis process seems to be complete after $0.8 \mathrm{~s}$ (with the majority of the changes well within $0.5 \mathrm{~s}$ ). This indicates that the pyrolysis processes in our wire-mesh reactor are faster than previously reported in literature.
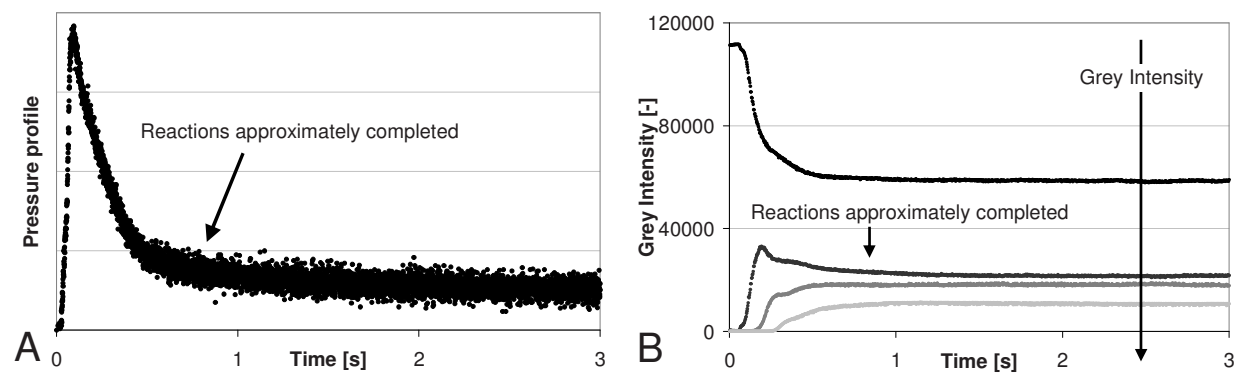

Figure 2.9 Pressure and grey intensity profiles of a typical experiment $\left(\mathrm{T} \sim 500{ }^{\circ} \mathrm{C}\right.$, holding time $\left.3 \mathrm{~s}\right)$. A) Pressure profile B) condensate profile

\subsection{Effect pressure and liquid nitrogen cooling}

\subsubsection{Comparison with our $1 \mathrm{~kg} / \mathrm{hr}$ pilot plant reactor: yields and gas composition}

The results of the wire-mesh experiments were compared to those obtained in our “conventional" $1 \mathrm{~kg} / \mathrm{hr}$ pyrolyser (section 2.3.6) with a typical gas/vapor phase residence time of 1-2 s. The same feedstock (Lignocel 9) was used, but the particle size of the wood was larger $(\sim 1 \mathrm{~mm})$. In the wire mesh reactor and under standard operating conditions ( $\mathrm{P}_{\mathrm{vac}} /$ Cooling), higher oil yields (84 wt\%; pilot plant $60 \mathrm{wt} \%$ ), considerably lower char 
yields (5 wt \%; pilot plant $15 \mathrm{wt} \%$ ) and lower gas yields (8-11 wt \%; pilot plant $25 \mathrm{wt} \%$ ) were obtained (Figure 2.10A). Overall, it is remarkable that some gas is still formed under the extreme conditions in our wire-mesh reactor. The char yield in our wire mesh reactor is much lower than typically encountered in (conventional) fast pyrolysis units. Other research groups ${ }^{37-40,46}$ who carried experiments in a wire-mesh reactor observed low char yields as well; their minimum reported char yield varies from 5-10 wt $\%$. The vapor residence time and also vapor temperature in the wire-mesh reactor can to a certain extent be increased by increasing the total pressure inside the reactor and by removal of the liquid nitrogen cooling (section 2.4.2, Table 2.4). These experiments in the wire mesh reactor were carried out to mimic the conditions in more conventional pyrolysis set-ups like our pilot plant reactor.

\subsubsection{Effect of pressure and cooling: yields and gas composition}

Figure 2.10 shows the importance of rapid cooling of the vapors. The experiment $\left(\mathrm{P}_{\mathrm{vac}} /\right.$ No Cooling) resulted in a higher gas yield $(+14 \mathrm{wt} \%)$, and a similar decrease in oil yield compared to the standard experiment $\left(\mathrm{P}_{\mathrm{vac}} / \mathrm{Cooling}\right)$. The formed gases contained relatively more $\mathrm{CO}, \mathrm{CH}_{4}$ and $\mathrm{C}_{2+}$. Based on literature data the $\mathrm{CO} / \mathrm{CO}_{2}$ ratio is expected to increase with increasing vapor phase reactions. It is reported that $\mathrm{CO}_{2}$ is mainly derived from the initial decomposition of $\operatorname{wood}^{39}$, cellulose ${ }^{71}$, hemicellulose ${ }^{72}$ and $\operatorname{lignin}^{73}$, while $\mathrm{CO}$ is formed by vapor phase reactions (chapter 4$) 2$. Due to circulation of the vapors/aerosols (Figure 2.5) in the vessel containing a higher temperature (Table 2.6) and recirculation of vapors/aerosols over the hot mesh, cracking reactions of volatiles to permanent gases are expected to be responsible for the lower oil and higher gas yields. The char yield in this experiment was the same as in the experiment using $\left(\mathrm{P}_{\mathrm{vac}} /\right.$ Cooling $)$. This suggests that the volatiles can be removed rapidly under vacuum from the solid (decomposing) biomass matrix thereby preventing charring reactions.

Figure 2.10 shows the effect when vacuum is replaced by nitrogen at atmospheric pressure. Using an inert nitrogen atmosphere $\left(\mathrm{P}_{\mathrm{atm}} /\right.$ Cooling $)$ resulted in lower oil yields (77 wt $\% ;-7 \mathrm{wt} \%)$ and higher char yields $(8 \mathrm{wt} \% ;+3 \mathrm{wt} \%)$ as compared to the experiments carried out under vacuum. The $\mathrm{CO} / \mathrm{CO}_{2}$ ratio increased marginally. Although it was shown earlier (Table 2.6) that the temperature inside the vessel was similar for $\mathrm{P}_{\mathrm{atm}} /$ Cooling and $\mathrm{P}_{\mathrm{vac}} /$ Cooling, the vapors might have cracked to additional gases when passing the hot mesh repeatedly (Figure 2.5). In line with this observation, a higher gas yield was observed $(15 \mathrm{wt} \% ;+4 \mathrm{wt} \%)$. The lower char yield under vacuum is thought to be related to the faster evaporation/sublimation of volatiles from the (decomposing) biomass matrix, thereby reducing polymerization (vapor-solid, liquidliquid, liquid-solid ${ }^{66,69,74}$ ) and thus charring. These data are in line with the observed higher char yields for the experiments carried out using larger particles (Table 2.9). In 
those experiments pyrolysis products are also expected to be removed at a slower rate from the solid biomass matrix.

The experiment $\left(\mathrm{P}_{\mathrm{atm}} / \mathrm{No}\right.$ Cooling) resulted in large differences with the reference experiment $\left(\mathrm{P}_{\mathrm{vac}} /\right.$ Cooling): the oil yield was lowered by $32 \mathrm{wt} \%$ (52 $\left.\mathrm{wt} \%\right)$, and the gas and char yield increased by $+30 \mathrm{wt} \%(41 \mathrm{wt} \%)$ and $+2 \mathrm{wt} \%(7 \mathrm{wt} \%)$, respectively. The formed gases contained relatively more $\mathrm{CO}, \mathrm{CH}_{4}$ and $\mathrm{C}_{2+}$ at the expensive of $\mathrm{CO}_{2}$. It should be noted that in this experiment the final temperature was $100{ }^{\circ} \mathrm{C}$ higher than the set temperature due to distortion of the pyrometer signal by an excessive amount of smoke.

Overall, these results clearly show that both the removal rate of products from the biomass matrix and the surrounding temperature have a large influence on product yields. Especially cooling appeared to be responsible for the suppression of cracking reactions of vapors to gases, while vacuum prevented the occurrence of charring reactions by enhancing the removal of volatiles from the (decomposing) biomass.

\subsubsection{Oil composition: wire-mesh reactor and pilot plant reactor}

To further study possible differences in oil characteristics SEC analysis was applied (Figure 2.11). For this, a THF/pyrolysis oil solution needs to be prepared. Pyrolysis oil from our pilot plant is generally completely soluble in THF (chapter 6$)^{58}$. However, the oils obtained in the wire mesh experiments using $\left(\mathrm{P}_{\mathrm{vac}} /\right.$ Cooling) were not completely soluble in THF: a white insoluble fraction remained. The yield of this fraction could not be determined accurately (weight basis), but was estimated not to be more than $5 \mathrm{wt} \%$ (weighing error) of the total oil. Although with lower yield, the production of this white fraction was also observed for $\mathrm{P}_{\mathrm{vac}} / \mathrm{No}$ Cooling and $\mathrm{P}_{\mathrm{atm}} /$ Cooling but not for the wire mesh experiments carried out using $\mathrm{P}_{\mathrm{atm}} / \mathrm{No}$ Cooling. This white THF insoluble fraction was soluble in water. Oasmaa et al. $^{75}$ defined the water soluble and ether insoluble fractions derived from pyrolysis oil as 'sugars'. HPLC analyses carried out by the University of Groningen (The Netherlands) confirmed that the THF insoluble fractions contained sugars. Levoglucosan was identified, but also several larger sugars which could not be identified appeared to be present. Separate SEC analysis of this white fraction was performed by first dissolving this fraction in water and hereafter in THF. The SEC chromatogram is shown in Figure 2.11A. This SEC analysis showed that the average molecular weight of this white fraction was significantly lower than the one of the remaining pyrolysis oil sample after THF extraction. These results suggest that in the wire mesh reactor using $\left(\mathrm{P}_{\mathrm{vac}} /\right.$ Cooling) a sugar fraction was obtained, which increasingly reacts to other products when approaching more "conventional" pyrolysis conditions. 
SEC results of the various oils (excluding the white fractions) are shown in Figure 2.11B and C. In general a shift to low molecular weights can be observed with an increase in expected extent of secondary reactions (pilot plant $>\mathrm{P}_{\mathrm{atm}} /$ No Cooling (wire mesh) $>$ $\mathrm{P}_{\mathrm{atm}} /$ Cooling and $\mathrm{P}_{\mathrm{vac}} / \mathrm{No}$ Cooling (wire-mesh) $>\mathrm{P}_{\mathrm{vac}} /$ Cooling (wire mesh)). This suggests that overall high molecular weight products, formed in the initial phase of the pyrolysis process, are cracked down to lower weight compounds inside the vapor phase and/or (decomposing) biomass matrix.
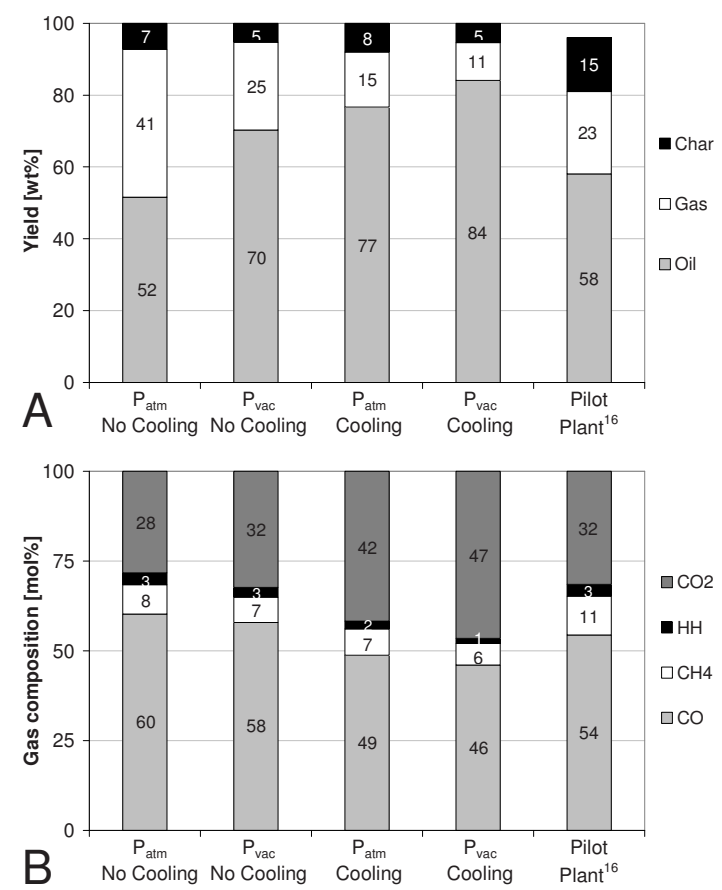

Figure 2.10 Yields obtained in wire mesh reactor and pilot plant (conditions reported in Table 2.4). Gas yields calculated with eq. 2b. First 3 columns: reported data are average values from 4 experiments, $\mathrm{P}_{\mathrm{vac}} /$ Cooling see Table 2.7 

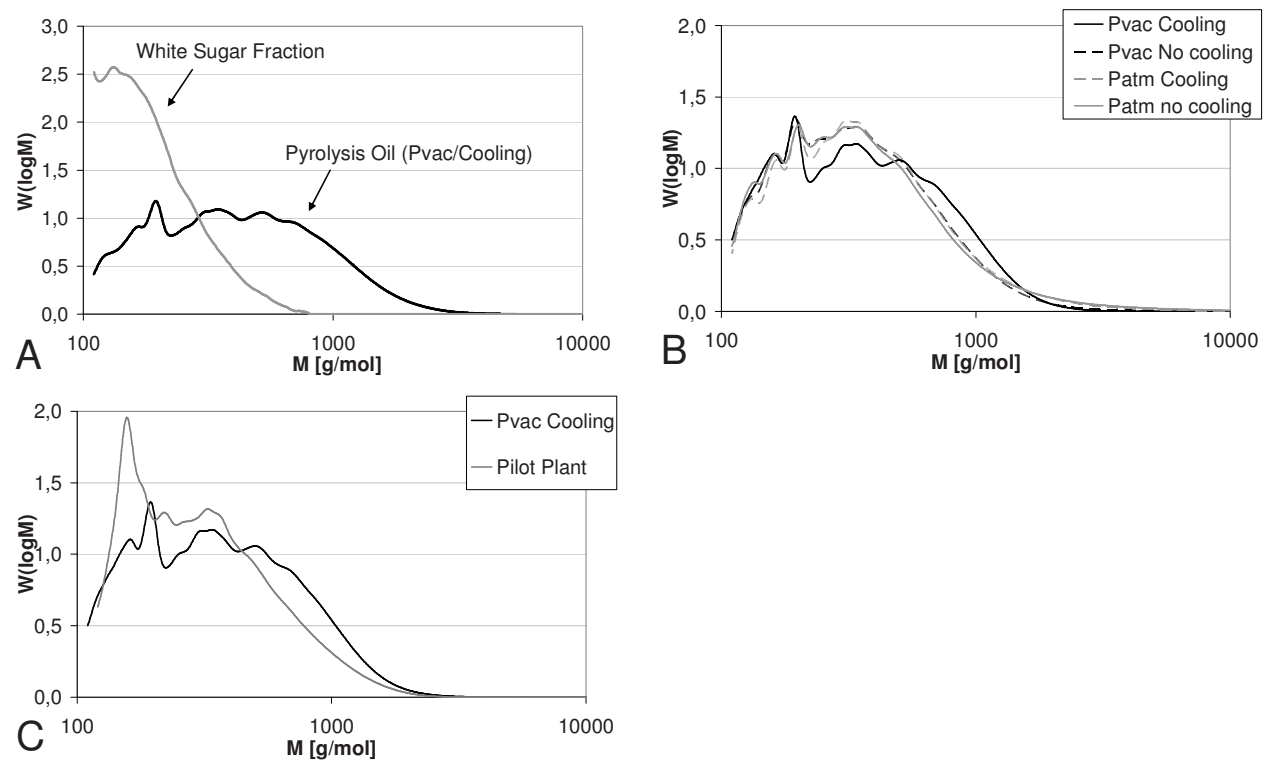

Figure 2.11 $\mathrm{M}_{\mathrm{w}}$-distributions A) white sugar fraction obtained in wire mesh using $\mathrm{P}_{\mathrm{vac}}$ Cooling B) pyrolysis oils wire-mesh reactor C) comparison wire-mesh and pilot plant reactor

\subsection{Conclusions}

Pyrolysis experiments were carried out in a novel wire-mesh reactor which was standard operated under vacuum and using liquid nitrogen cooling of the reactor wall to ensure immediate condensation of pyrolysis vapors. Extremely low vapor residence times $(<15$ $25 \mathrm{~ms}$ ) and low vapor temperatures were realized. The vapor residence time and also vapor temperature can to a certain extent be increased by increasing the total pressure inside the reactor and by removing of the liquid nitrogen cooling. The experimental setup was validated extensively, showing good mass balance closure (between 90 and 110 $\mathrm{wt} \%)$. In a typical run high heating rates $\left(7.0 \cdot 10^{3} \mathrm{C} / \mathrm{s}\right)$, an even spatial mesh temperature distribution $\left( \pm 35{ }^{0} \mathrm{C}\right)$ and good temperature control of the measuring spot during the holding period $\left( \pm 5^{0} \mathrm{C}\right)$ were achieved. Reproducible results concerning oil (SEC, NMR), gas (GC) and char (FTIR) composition were obtained. Four identical runs are sufficient to obtain average values for the oil and char yield within 5 and $1 \mathrm{wt} \%$ points respectively (CI level $90 \%$ ). Stainless steel wire-meshes seemed not to be catalytically active, which was proven using gold sputtered meshes as reference. Although the biomass mass used in the wire mesh experiments was very low (0.05-0.1 g), the product yields and composition still changed with biomass loading. 
Compared to more "conventional" pyrolysis processes like our fluidized bed pilot plant reactor $\left(\mathrm{d}_{\mathrm{p}} \sim 1 \mathrm{~mm}, \mathrm{t}_{\mathrm{vapors}} 1-2 \mathrm{~s}\right)$, high oil yields ( $\left.84 \mathrm{wt} \%\right)$, very low char yields $(5 \mathrm{wt} \%)$ and low gas yields $(8 \mathrm{wt} \%)$ were obtained in the wire mesh reactor $\left(\mathrm{P}_{\mathrm{vac}} /\right.$ Cooling $)$. Results indicate that the biomass conversion process was finished within $0.8 \mathrm{~s}$, which is much faster than can be derived from kinetic expressions in literature. The low char yield might be explained by the fast high heating rates and fast removal of volatiles from the (decomposing) biomass matrix leaving less time for polymerization. The low gas yield is likely to be explained by suppression of vapor phase reactions. Especially an increase in gas yield (+14 wt\%, mainly $\mathrm{CO})$ was observed in absence of cooling $\left(\mathrm{P}_{\mathrm{vac}} /\right.$ No Cooling), while both the gas $(+4 \mathrm{wt} \%)$ and char yield $(+3 \mathrm{wt} \%)$ increased under atmospheric pressure $\left(\mathrm{P}_{\mathrm{atm}} /\right.$ Cooling), all at the expense of oil yield. So, cooling appeared to be mainly responsible for the suppression of cracking reactions of vapors to gases, while vacuum prevented the occurrence of charring reactions by enhancing the removal of volatiles from the (decomposing) biomass. When comparing the molecular weight of the various oils, it was found that upon an (expected) increase in vapor phase reactions and subsequent reactions in the (decomposing) biomass, the molecular weight decreased. Other than this, the pyrolysis oil produced in the wire mesh reactor $\left(\mathrm{P}_{\text {vac }} /\right.$ Cooling) contained a white, THF insoluble, sugar fraction.

\section{Abbreviations}

$\begin{array}{ll}\text { BD } & \text { By difference } \\ \text { E.A. } & \text { Elemental analyzer } \\ \text { FTIR } & \text { Fourier transform infrared spectroscopy } \\ \text { HPLC } & \text { High performance liquid chromatography } \\ \text { G } & \text { Gravemetric } \\ \text { GC } & \text { Gas Chromatograph } \\ C_{2+} & \mathrm{C}_{2} \mathrm{H}_{4}+\mathrm{C}_{2} \mathrm{H}_{6}+\mathrm{C}_{3} \mathrm{H}_{6}+\mathrm{C}_{3} \mathrm{H}_{8} \\ \text { NMR } & \text { Nuclear Magnetic Resonance } \\ \text { SEC } & \text { Size Exclusion Chromatography } \\ \text { UVFS } & \text { Ultraviolet Fluorescence Spectroscopy } \\ \text { v.p.o. } & \text { vapor pressure osmometry }\end{array}$




\section{References}

1. A. Broido, M. Weinstein, Low temperature isothermal pyrolysis of cellulose, Thermal analysis vol 3. - proceedings third ICTA DAVOS 1971

2. E. Hoekstra, R.J.M. Westerhof, M. Windt, W. Brilman, W.P.M. van Swaaij, S.R.A. Kersten, J.A. Hogendoorn, Heterogeneous and homogeneous reactions of pyrolysis vapors from pine wood, AIChE-Journal, accepted for publication (chapter 4 of this thesis)

3. K. Sipilä, E. Kuoppala, L. Fagernäs, A. Oasmaa, Characterization of biomass-based flash pyrolysis oils, Biomass and Bioenergy, 14 (2), 103-113, 1998

4. A.V. Bridgwater, G.V.C. Peacocke, Fast pyrolysis processes for biomass, Renewable sustainable energy ReV., 4(1), 1-73, 2000

5. L. Ingram, D. Mohan, M. Bricka, P. Steele, D. Strobel, D. Crocker, B. Mitchell, J. Mohammed, K. Cantrell, C.U. Pittman, Pyrolysis of wood and bark in an auger reactor: physical properties and chemical analysis of the produced bio-oils, Energy and Fuels, 22, 614-625, 2008

6. S.R.A. Kersten, X. Wang, W. Prins, W.P.M. van Swaaij, Biomass pyrolysis in a fluidized bed reactor. Part 1: literature review and model simulations, Ind. Eng. Chem. Res. 44, 8773-8785, 2005

7 R.J. Evans, T.A. Milne, Molecular characterization of the pyrolysis of biomass 1. Fundamentals, Energy and Fuels, 1 (2), 123-137, 1987

8. C. Di Blasi, C. Branca, Kinetics of primary product formation from wood pyrolysis, Ind. Eng. Chem. Res., 40 (23), 5547-5556, 2001

9. M.W. Hopkins, M.J. Antal, Radiant flash pyrolysis of biomass using a xenon flash tube, J. Appl. Polym. Sci., 29, 2163-2175, 1984

10. J. Lede, F. Blanchard, O. Boutin, Radiant flash pyrolysis of cellulose pellets: product and mechanisms involved in transient and steady state conditions, Fuel, 81, 1269-1279, 2002

11. O. Boutin, M. Ferrer, J. Lede, Radiant flash pyrolysis of cellulose - evidence for the formation of short life time intermediate liquid species, J. Anal. Appl. Pyrolysis, 47, 13-31, 1998

12. P.R. Patwardhan, J. A. Satrio, R.C. Brown, B.H. Shanks, Product distribution from fast pyrolysis of glucose-based carbohydrates, J. Anal. Appl. Pyrolysis, 86, 323-330, 2009

13. M. Garcia-Perez, A. Chaala, C. Roy, Vacuum pyrolysis of sugarcane bagasse, J. Anal. Appl. Pyrolysis, 65, 111-136, 2002

14. M.R. Hajaligol, J.B. Howard, W.A. Peters, An experimental and modeling study of pressure effects on tar release by rapid pyrolysis of cellulose sheets in a screen heater, Combust. Flame, 95, 47-60, 1993

15. E. Hoekstra, J.A. Hogendoorn, X. Wang, R.J.M. Westerhof, S.R.A. Kersten, W.P.M. van Swaaij, M.J. Groeneveld, Fast pyrolysis of biomass in a fluidized bed reactor: in-situ filtering of the vapors. Ind. Eng. Chem. Res., 48, 4744-4756, 2009 (chapter 5 of this thesis)

16. R.J.M Westerhof, N.J.M. Kuipers, S.R.A. Kersten, W.P.M. van Swaaij, Controlling the water content of biomass fast pyrolysis oil, Ind. Chem. Res., 46, 9238-9247, 2007

17. R.J.M. Westerhof, D.W.F. Brilman, W.P.M. van Swaaij, S.R.A. Kersten, Effect of temperature on fluidized bed fast pyrolysis of biomass: oil quality assessment in test units, Ind. Eng. Chem. Res., 49, 1160-1168, 2010

18. L. Gao, L. Wu, N. Paterson, D. Dugwell, R. Kandiyoti, The use of wire mesh reactors to characterise solid fuels and provide improved understanding of larger scale thermochemical processes, Int. J. Oil, Gas and coal technology, 1, 152-178, 2008

19. J.D. Freihaut, W.M. Proscia, Tar evolution in heated-grid apparatus, Energy and Fuels, 3, 625-635, 1989

20. J. Gibbins-Matham, R. Kandiyoti, Coal pyrolysis yields from fast and slow heating in a wire-mesh apparatus with a gas sweep, Energy and Fuels, 2, 505-511, 1988

21. J.R. Gibbins, R.A.V. King, R.J. Wood, R. Kandiyoti, Variable-heating-rate wire-mesh pyrolysis apparatus, Rev. Sci. Instrum. 60(6), 1129-1138, 1989

22. J. Gibbins, R. Kandiyoti, Experimental study of coal pyrolysis and hydropyrolysis at elevated pressures using a variable heating rate wire-mesh apparatus, Energy and Fuels, 3, 670-677, 1989

23. A.J. Guell, R. Kandiyoti, Development of a gas-sweep facility for the direct capture of pyrolysis tars in a variable heating rate high-pressure wire-mesh reactor, Energy and Fuels, 7, 943-952, 1993

24. E.M. Suuberg, W.A. Peters, J.B. Howard, Product composition and kinetics of lignite pyrolysis, Ind. Eng. Chem. Process Des. Dev., 17(1), 112-136, 1978 
25. E.M. Suuberg, W.A. Peters, J.B. Howard, Product compositions in rapid hydropyrolysis of coal, Fuel, 59, 405-412, 1980

26. P.E. Unger, E.M. Suuberg, Molecular weight distributions of tars produced by flash pyrolysis of coals, Fuel, 63, 606-611, 1984

27. E.M. Suuberg, P.E. Unger, W.D. Lilly, Experimental study on mass transfer from pyrolysing coal particles, Fuel, 64, 956-962, 1985

28. T.P. Griffin, J.B. Howard, W.A. Peters, Pressure and temperature effects in bituminous coal pyrolysis: experimental observations and transient lumped-parameter model, Fuel, 73(4), 591-601, 1994

29. L.H. Hamilton, A.B. Ayling, M. Shibaoka, A new experimental device for pyrolysing coal particles under controlled conditions over a wide range of heating rates, Fuel, 58, 873-876, 1979

30. P. Arendt, K. Heinrich van Heek, Comparative investigations of coal pyrolysis under inert gas and $\mathrm{H}_{2}$ at low and high heating rates and pressures up to $10 \mathrm{MPa}$, Fuel, 60, 779-787, 1981

31. R.W.J. Westerhout, R.H.P. Balk, R. Meijer, J.A.M. Kuipers, W.P.M. van Swaaij, Examination and evaluation of the use of screen heaters for the measurement of the high temperature pyrolysis kinetics of polyethene and polypropene, Ind. Eng. Chem. Res., 36, 3360-3368, 1997

32. M.R. Hajaligol, J.B. Howard, J.P. Longwell, W.A. Peters, Product compositions and kinetics for rapid pyrolysis of cellulose, Ind. Eng. Chem. Process Des. Dev., 21 (3), 457-464, 1982

33. P.C. Lewellen, W.A. Peters, J.B. Howard, Cellulose pyrolysis kinetics and char formation mechanism, Symposium (International) on combustion, 16 (1), 1471-1480, 1977

34. T.R. Nunn, J.B. Howard, J.P. Longwell, W.A. Peters, Product compositions and kinetics in the rapid pyrolysis of milled wood lignin, Ind. Eng. Chem. Process. Des. Dev.,24, 844-852, 1985

35. B. Iatridis, G.R. Gavalas, Pyrolysis of a precipitated kraft lignin, Ind. Eng. Chem. Prod. Res. Dev. 18(2), 127-130, 1979

36. A.R. Fraga, A.F. Gaines, R. Kandiyoti, Characterization of biomass pyrolysis tars produced in the relative absence of extraparticle secondary reactions, Fuel, 70, 803-809, 1991

37. G.V.C. Peacocke, E.S. Madrali, C.Z. Li, A.J. Guell, F. Wu, R. Kandiyoti, A.V. Bridgwater, Effect of reactor configuration on the yields and structures of pine-wood derived pyrolysis liquids: a comparison between ablative and wire-mesh pyrolysis, Biomass and Bioenergy, 7, 155-167, 1994

38. A.R.F. Drummond, I.W. Drummond, Pyrolysis of sugar cane bagasse in a wire-mesh reactor, Ind. Eng. Chem. Res., 35, 1263-1268, 1996

39. T.R. Nunn, J.B. Howard, J.P. Longwell, W.A. Peters, Product compositions and kinetics in the rapid pyrolysis of sweet gum hardwood, Ind. Eng. Chem. Process Des Dev., 24, 836-844, 1985

40. M. Nik-Azar, M.R. Hajaligol, M. Sohrabi, B. Dabir, Effects of heating rate and particle size on the products yields from rapid pyrolysis of beech wood, Fuel Sci, Technol. Int., 14(4), 479-502, 1996

41. M. Flower, J. Gibbins, A radiant wire mesh single-particle biomass combustion apparatus, Fuel, 88(12), 2418-2427, 2009

42. M.J. Prins, J. Linden, Z.S. Li, R.J.M. Bastiaans, J.A. van Oijen, M. Alden, L.P.H. de Goey, Visualization of biomass pyrolysis and temperature imaging in a heated-grid reactor, Energy and Fuels, 23(2), 993-1006, 2009

43. W. de Jong, A. Slabbekoorn, J. Guo, A. Veefkind, Heated grid flash pyrolysis of miscanthus with in-situ infrared spectrometry species analysis and comparison with FG-DVC biomass model simulations, in Expert meeting on pyrolysis and gasification of biomass waste, Strasbourg, France, $111-123,2002$

44. A. Zabaniotou, Th. Damartzis, Modelling the intra-particle transport phenomena and chemical reactions of olive kernel fast pyrolysis, J. Anal. Appl. Pyrolysis, 80, 187-194, 2007

45. Th. Damartzis, G. Ionnidis, A. Zabaniotou, Simulating the behavior of a wire mesh reactor for olive kernel fast pyrolysis, Chem. Eng. J., 136, 320-330, 2008

46. J.F. Stubington, S. Aiman, Pyrolysis kinetics of bagasse at high heating rates, Energy and Fuels, 8, 194-203, 1994

47. M. Nik-Azar, M.R. Hajaligol, M. Sohrabi, B. Dabir, Mineral matter effects in rapid pyrolysis of beech wood, Fuel. Process. Technol., 51, 7-17, 1997

48. A.J. Guell, C.Z. Li, A.A. Herod, B.J. Stokes, P. Hancock, R. Kandiyoti, Effect of $\mathrm{H}_{2}$ pressure on the structures of bio-oil from the mild hydropyrolysis of biomass, Biomass and Bioenergy, 5(2), 155-171, 1993 
49. R.V. Pindoria, I.N. Chatzakis, J.Y. Lim, A.A. Herod, D.R. Dugwell, R. Kandiyoti, Hydropyrolysis of sugar cane bagasse: effect of sample configuration on bio-oil yields and structures from two bench scale reactors, Fuel, 78, 55-63, 1999

50. A.A. Zabaniotou, D. Gogotsis, A.J. Karabelas, Product composition and kinetics of flash pyrolysis of Erica Arborea (biomass), J. Anal. Appl. Pyrolysis, 29, 73-87, 1994

51. A. Zabaniotou, O. Ioannidou, V. Skoulou, Rapeseed utilization for energy and 2nd generation biofuels, Fuel, 87, 1492-1502, 2008

52. A. Zabaniotou, O. Ioannidou, E. Antonakou, A. Lappas, Experimental study of pyrolysis for potential energy, hydrogen and carbon material production from lignocellulosic biomass, Int. J. Hydrogen Energy, 33, 2433-2444, 2008

53. O. Ioannidou, A. Zabaniotou, E.V. Antonakou, K.M. Papazisi, A.A. Lappas, C. Athanassiou, Investigation the potential for energy, fuel, materials and chemical production from corn residues (cobs and stalks) by non-catalytic and catalytic pyrolysis in two reactor configurations, Renew. Sust. Energ. Rev., 13, 750-762, 2009

54. Th. Damartzis, M. Kostoglou, A. Zabaniotou, Simulation of the agro-biomass (olive Kernel) fast pyrolysis in a wire mesh reactor considering intra-particle radial and temporal distribution of products, Int. J. Chem. React. Eng, 7, 2009

55. T. Okuno, N. Sonoyama, J.I. Hayashi, C.Z. Li, C. Sathe, T. Chiba, Primary release of alkali and alkaline earth metallic species during the pyrolysis of pulverized biomass, Energy and Fuels, 19, 2164-2171, 2005

56. G. Di Nola, W. de Jong, H. Spliethoff, The fate of main gaseous and nitrogen species during fast heating rate devolatilization of coal and secondary fuels using a heated wire mesh reactor, Fuel Process. Technol., 90(3), 388-395, 2009

57. J.P. Diebold, S. Czernik, Additives to lower and stabilize the viscosity of pyrolysis oils during storage. Energy and Fuels, 11, 1081-1091, 1997

58. E. Hoekstra, S.R.A. Kersten, A.J. Tudos, D. Meier, J.A. Hogendoorn, Possibilities and pitfalls in analyzing (upgraded) pyrolysis oil by Size Exclusion Chromatography (SEC), J. Anal. Appl. Pyrolysis, 91(1), 76-88, 2011 (chapter 6 this thesis)

59. M. Bellais, Modelling of the pyrolysis of large wood particles, PhD-thesis, Stockholm, Sweden, 2007

60. R. Byron Bird, W.E. Stewart, E.N. Lightfoot, Transport Phenomena, Second edition, John Wiley and Sons, 2002

61. B.S. Kang, K.H. Lee, H.J. Park, Y.K. Park, J.S. Kim, Fast pyrolysis of radiate pine in a bench scale plant with a fluidized bed: influence of a char separation system and reaction conditions on the production of bio-oil, J. Anal. Appl. Pyrolysis, 76, 32-37, 2006

62. G. Chen, J. Andries, H. Spliethoff, Experimental investigation of biomass waste (rice straw, cotton stalk, pine sawdust) pyrolysis characteristics, Energy Sources, 25, 331-337, 2003

63. J.L. Devore, Probability and statistics for engineering and the sciences, Duxbury, Thomson Learning, 2000

64. http://www.euro-inox.org/technical_tables/index.php, visited July 2010

65. G.N. Richards, G. Zheng, Influence of metal ions and of salts on products from pyrolysis of wood: applications to thermochemical processing of newsprint and biomass, Fuel 88, 1810-1817, 2009

66. M.L. Boroson, J.B. Howard, J.P. Longwell, W.A. Peters, Heterogeneous cracking of wood pyrolysis tars over fresh char surfaces, Energy and Fuels, 3, 735-740, 1989

67. J. Shen, X.S. Wang, M. Garcia-Perez, D. Mourant, M.J. Rhodes, C.Z. Li, Effects of particle size on the fast pyrolysis of oil mallee woody biomass, Fuel, 88, 1810-1817, 2009

68. D. Mohan, C.U. Pittman, P.H. Steele, Pyrolysis of wood/biomass for bio-oil: a critical review, Energy and Fuels, 20, 848-889, 2006

69. T.J. Haas, M.R. Nimlos, B.S. Donohoe, Real-time and post-reaction microscopic structural analysis of biomass undergoing pyrolysis, Energy and Fuels, 23, 3810-3817, 2009

70. F. Thurner, U. Mann, Kinetic investigation of wood pyrolysis, Ind. Eng. Chem. Process Des. Dev., 20, 482-488, 1981

71. D.K. Shen, S. Gu, The mechanism for thermal decomposition of cellulose and its main products, Biosource Technology, 100, 6496-6504, 2009

72. D.K. Shen, S. Gu, A.V. Bridgwater, Study on the pyrolytic behaviour of xylan-based hemicellulose using TG-FTIR and Py-GC-FTIR, J. Anal. Appl. Pyrolysis, 87, 199-206, 2010 


\section{Chapter 2}

73. D.K. Shen, S. Gu, K.H. Luo, S.R. Wang, M.X. Fang, The pyrolytic degradation of wood-derived lignin from pulping process, Bioresource technology, 101, 6136-6146, 2010

74. V. Mamleev, S. Bourbigot, M. Le Bras, J. Yvon, The facts and hypthesis relating to the phenomenological model of cellulose pyrolysis. Interdependence of the steps, J. Anal. Appl. Pyrolysis, 84, 1-17, 2009

75. A. Oasmaa, E. Kuoppala, Y. Solantausta, Fast pyrolysis of forestry residue. 2. Energy and Fuels, 17, 433-443, 2003 
Chapter 3

\section{Fast pyrolysis in a novel wire-mesh reactor: decomposition of pine wood and model compounds}

In fast pyrolysis, biomass decomposition reactions are followed by vapor phase reactions. In this study, experimental results were obtained in a unique wire-mesh reactor using pine wood, $\mathrm{KCl}$ impregnated pine wood and several model compounds as feedstock. The wire-mesh reactor was typically operated at a set-temperature of $500{ }^{\circ} \mathrm{C}$, high heating rates (up to $7000{ }^{\circ} \mathrm{C} / \mathrm{s}$ ) under vacuum and with liquid nitrogen cooling to ensure a short vapor residence time $(<15-25 \mathrm{~ms})$ and a low vapor phase temperature. In this way good suppression of vapor phase reactions and reactions inside the decomposing particle were achieved as also shown by the (almost) complete recovery of glucose and levoglucosan after pyrolysis. The influence of temperature $\left(250-700^{\circ} \mathrm{C}\right)$ and heating rate $\left(50-7000{ }^{\circ} \mathrm{C} / \mathrm{s}\right)$ was studied on product yields and compositions (GC, SEC, NMR, FTIR, HPLC). A high oil yield of 84 wt\% and a low char yield of 5 wt\% was observed for pine-wood around $500{ }^{\circ} \mathrm{C}$. Above this temperature a slight drop in oil yield was observed, but the oil yield was still $60 \mathrm{wt} \%$ at $700{ }^{\circ} \mathrm{C}$. Also high oil yields and low char were obtained during the pyrolysis of cellulose (oil/char:95/0 wt\%) and lignin (oil/char: 78/12 wt\%). Our data were interpreted with a physical-chemical mechanism. The basic idea behind this mechanism is that the amount and composition of the "decomposing biomass", which can be in the solid or liquid state under the pyrolysis conditions, is changing in time due to competition between (cross)-linking reactions, scission reactions and mass transfer of decay fragments out of the decomposing particle. Observations such as the twice as large char yield for K-impregnated pine wood (10 wt\% char) compared to untreated pine wood (5 wt\%) and the $20 \mathrm{wt} \%$ increase in char yield from lignin when decreasing the heating rate from 6000 to $60{ }^{\circ} \mathrm{C} / \mathrm{s}$ could be explained by this mechanism. 


\subsection{Introduction}

Fast pyrolysis is an attractive option for the conversion of bulky solid biomass into a liquid fuel with an energy density about half of that of fossil fuels. Pyrolysis is the thermochemical decomposition of organic material (such as wood, crops, residues) at ca. $500{ }^{0} \mathrm{C}$ in the absence of oxygen. Under these conditions, vapors, aerosols, permanent gases and char are formed. The vapors and aerosols are condensed to pyrolysis oil (also known as bio-oil) $)^{1-3}$. Pyrolysis oil consists of hundreds of oxygenated compounds; the major chemical groups are water (15-30 wt \%), monomeric carbonyls, sugars, organic acids, phenols, and oligomerics originating from carbohydrates and lignin degradation ${ }^{4}$. The amount and composition of char, oil and gases depends on the feedstock and process variables like particle size, temperature, heating rate and vapor residence time ${ }^{1-3}$.

In fast pyrolysis, biomass decomposition reactions are followed by homogeneous and heterogeneous vapor phase reactions. Cracking reactions are known to occur in the vapor phase at high temperatures and vapor phase polymerization reactions are known to be accelerated by the presence of minerals (chapter 4)5. In this chapter, results on the biomass decomposition reactions obtained in the (near) absence of vapor phase reactions are reported. For this we used a wire-mesh reactor that has been described and extensively validated in chapter $2^{6}$. The residence time of the volatiles in our wire-mesh reactor was estimated to be only 15-25 (chapter 2),6 whereas they may spend several seconds at elevated temperatures and possibly in the presence of minerals in "conventional set-ups" (e.g. fixed bed, fluidized bed, entrained flow e.g.)

In this chapter experimental results will be presented that were obtained in the wire-mesh reactor using biomass (pine, pine $+\mathrm{KCl}$ ) and several model compounds (xylan, cellulose, lignin, levoglucosan, glucose) as feedstock. The influence of process parameters like temperature and heating rate was studied. Results are interpreted using a physicalchemical mechanism describing the decomposition of biomass. 


\subsection{Biomass decomposition mechanism}

\subsubsection{Reaction mechanisms proposed in literature}

Several fast pyrolysis mechanisms of varying complexity have been reported in literature. In these mechanisms, pyrolysis products are typically lumped into three main categories: char, gas and volatiles. Oil, also called tar, is formed after condensation of the volatiles. Five important decomposition mechanisms developed before the nineties are reported in Table 3.1.

Table 3.1 Reaction mechanisms proposed in literature

\begin{tabular}{|c|c|}
\hline $\begin{array}{l}\text { cellulose } \longrightarrow \text { "dehydrocellulose" }+\mathrm{H}_{2} \mathrm{O} \longrightarrow \text { char }+\mathrm{H}_{2} \mathrm{O}+\mathrm{CO}+\mathrm{CO}_{2} \text { etc. } \\
\text { oil (primarily levoglucosan) }\end{array}$ & $\begin{array}{c}\text { Kilzer and Broido } \\
{[1965]^{7}}\end{array}$ \\
\hline $\begin{array}{c}\text { cellulose } \\
\mathrm{A} \longrightarrow \mathrm{B} \\
\mathrm{B}\end{array} \underset{\substack{\text { active cellulose } \\
\text { volatiles } \\
\mathrm{B}^{\prime}}}{\mathrm{C}} \stackrel{\mathrm{D}}{\longrightarrow} \mathrm{E}$ & $\begin{array}{c}\text { Broido and Weinstein } \\
{[1971]^{8}}\end{array}$ \\
\hline $\begin{array}{l}\longrightarrow \text { volatiles } \\
\longrightarrow \text { char }+ \text { gas }\end{array}$ & $\begin{array}{c}\text { Shafizadeh } \\
{[1979]^{9,10}}\end{array}$ \\
\hline biomass $\longrightarrow$ intermediate $\longrightarrow$ char & $\begin{array}{c}\text { Koufopanos } \\
{[1989]^{11}}\end{array}$ \\
\hline $\begin{array}{ll} & \\
\text { biomass } \longrightarrow & \text { char } \\
\text { volatiles } \\
\text { gas }\end{array}$ & $\begin{array}{l}\text { Three step mechanism } \\
\text { Shafizadeh and Chin } \\
{[1977]^{12,13}}\end{array}$ \\
\hline
\end{tabular}

Cellulose was taken as starting point in the majority of the mechanisms reported in literature instead of the complex biomass structure. Kilzer and Broido ${ }^{7}$, Broido and Weinstein ${ }^{8}$ and Shafizadeh ${ }^{9,10}$ started from cellulose, while Koufopanos ${ }^{11}$ and Shafizadeh and Chin (three step mechanism) ${ }^{12,13}$ started from biomass (see Table 3.1). In the Koufopanos mechanism, the biomass pyrolysis rate is considered to be the sum of the decomposition rate of the main biomass components: cellulose, hemicellulose and lignin. This assumes the absence of interactions between the biomass components and their reaction products. From several TGA studies ${ }^{14}$, it is well known that cellulose and hemicellulose degrade over a small, but overlapping, temperature range $\left(260-430{ }^{\circ} \mathrm{C}\right.$ and $200-350{ }^{\circ} \mathrm{C}$ respectively), while lignin decomposes over a temperature range that spans these of hemicelluose and cellulose $\left(200-500{ }^{0} \mathrm{C}\right)$. Although, literature results concerning the interactions of biomass compounds are limited and not in complete agreement, interactions were shown to occur ${ }^{14-16}$. It seems unlikely that the detailed pyrolysis behaviour of biomass can be predicted by the sum of the pyrolysis behaviour of hemicellulose, cellulose and lignin without taking into account the effects of ash, minerals, extractives and interactions between the major fractions ${ }^{17}$. 
Broido and Weinstein ${ }^{8}$, Shafizadeh ${ }^{9,10}$ and Koufopanos ${ }^{11}$ postulated an initial reaction step not associated with any weight loss, but resulting in a material having a lower degree of polymerization. Broido and Weinstein ${ }^{8}$, and Shafizadeh" ${ }^{9,10}$ named this material "active cellulose", while Koufopanos ${ }^{11}$ called it "intermediate" considering the whole biomass as feedstock. For cellulose this material was reported to have a degree of polymerization $\left(d_{p}\right)$ of about 200 units $^{18-20}$. At this point in time, no consensus about the occurrence of such a clearly distinguishable initiation step exists in literature. The reaction of cellulose to "activated cellulose" is reported to be very fast or not to take place at all ${ }^{21,22}$. In the three step mechanism ${ }^{12,13}$ the "intermediate" is simply omitted.

In the mechanisms reported in Table 3.1, the feedstock or "depolymerised intermediate" is assumed to decompose (further) by two or three parallel reactions. In reality each of these reactions corresponds to a group of reactions. In the Shafizadeh and Kilzer and Broido mechanism char and gas are formed simultaneously in a fixed ratio (0.35:0.65 in the mechanism of Shafizadeh $)^{9,10}$, while Koufopanos ${ }^{11}$ postulates a relation between the volatiles and gas formation. Although char and gas can be formed simultaneously in, for example, condensation reactions, cracking reactions can lead to the formation of gas/volatiles without additional char formation ${ }^{23}$. Apparently, gases can be formed via different reaction pathways, and the assumption of a unique link between only char-gas or volatiles-gas formation is not justified. Contradictory to these two mechanisms, the three step mechanism assumes biomass to decompose via three parallel reactions. Overall, this may be observed, but it cannot be a correct representation on molecular level.

The mechanism of Broido and Weinstein ${ }^{8}$ includes a sequence of reactions in the solid cellulose matrix, represented by $\mathrm{C}, \mathrm{D}$ and $\mathrm{E}$ in Table 3.1. Although they mentioned in their article that small molecules (mainly water) were split of in this sequence, they did not include this in their mechanism. In line with this, Chaiwat et al. ${ }^{24}$ and Radlein ${ }^{25}$ discussed the occurrence of cross-linking reactions inside the (decomposing) cellulose and biomass matrix respectively. Char, water, $\mathrm{CO}_{2}$ and cross-linked oil molecules were reported to be formed in these reactions ${ }^{24,25}$.

Besides chemical, also physical processes like vaporization, sublimation and physical entrainment are playing an important role. Liquids are reported to be formed during the pyrolysis of coal $^{26}$, cellulose ${ }^{27-29}$ hemicellulose ${ }^{29}$, lignin ${ }^{28,30}$ and biomass ${ }^{31}$. Diebold et al. $^{20}$ discussed the importance of vaporization during the pyrolysis of cellulose. In addition to vaporization, Radlein ${ }^{25}$ argued about the physical entrainment of aerosols directly from a pyrolysis biomass particle. Fisher et al. ${ }^{29}$ observed burst bubbles in their pyrolyzed feedstock which is an indication that aerosols, gases and vapors were swept away from their residue. 


\subsubsection{Reaction mechanism for the decomposition of biomass}

Based on the discussion in section 3.2.1, the random chain model ${ }^{32}$ and results obtained in our wire mesh set-up ${ }^{\text {(chapter 2)6 }}$ we are postulating the mechanism shown in Figure 3.1. Biomass is used as starting point, but it can also be replaced by any other (model) compound. It should be emphasized that only the decomposition of the biomass is included: possible subsequent homogeneous and heterogeneous reactions of the vapors as described in chapter $4^{5}$ are thus outside the scope of this mechanism. It is not our intention to mathematically predict accurately any yields or compositions. We want to enlarge the understanding of the very complex pyrolysis process with the postulated mechanism.

The basic idea behind our mechanism is that the amount and composition of the biomass/"decomposing biomass" is changing in time due to chemical reactions and physical mass transfer processes. Biomass is assumed to decompose via a series of time steps $\left(\mathrm{t}_{\mathrm{i}}\right)$ forming "gas", "vapors/aerosols" and further "decomposing biomass". It should be noted that "gas" and "vapors/aerosols" are not necessarily formed in each of these steps, because "decomposing biomass" to "decomposing biomass" reactions without the formation of those compounds are expected to occur as well. "Gas", "vapors/aerosol" and "decomposing biomass" can be formed in parallel or in the same reaction. Unlike many other studies $^{9-11}$ no fixed relation between the pyrolysis products is assumed. Pyrolysis oil is made up of the sum of the $\left(\mathrm{t}_{\mathrm{i}}\right)$ condensed "vapors/aerosols" fractions and gas the sum of the "gas" fractions formed in each of the time steps $\left(\mathrm{t}_{\mathrm{i}}\right)$. Char is the remaining (cooled) "decomposed feedstock" after the last step $\left(\mathrm{t}_{\mathrm{end}}\right)$.

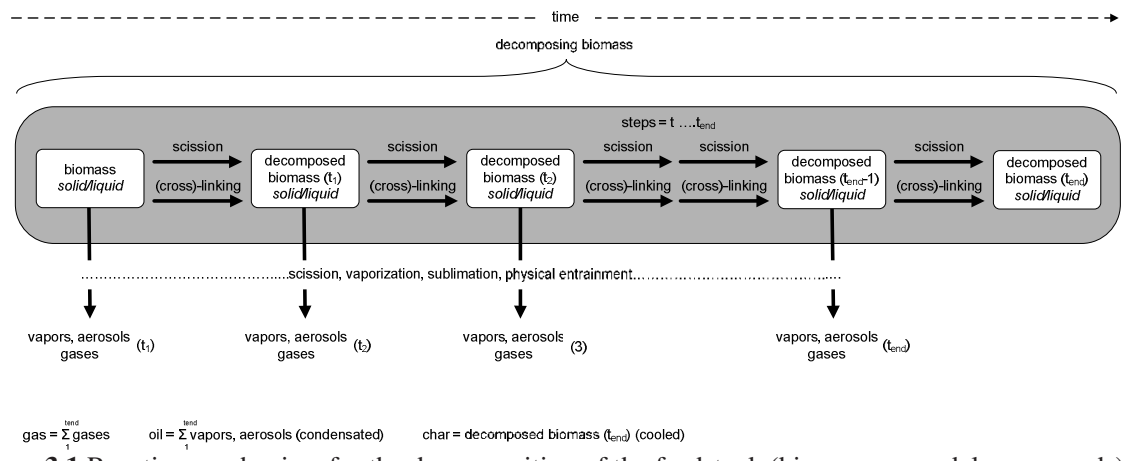

Figure 3.1 Reaction mechanism for the decomposition of the feedstock (biomass or model compounds)

In the proposed model, the reactions in "decomposing biomass" leading to a change in its structure or to mass loss are classified as scission and (cross)-linking reactions. Overall, these reactions are assumed to take place in parallel in each step. Their respective rate is dependent on the prevailing process conditions and the (remaining) concentration of bonds susceptible to these reactions. 


\section{Scission}

Molecular bonds are broken by scission. Examples of scission reactions are: depolymerisation of cellulose, cracking of various side-chain structures from aromatic rings $^{23}$ and the formation of small molecules during condensation reactions. Scission reactions result in smaller fragments. These fragments can be in solid, liquid, vapor or gaseous phase. The latter two can escape from the "decomposing biomass" by mass transfer. Solid fragments formed upon scission are basically "decomposing biomass", and because of that also classified as such. The liquid formed upon biomass decomposition can result in the 'liquid pools'. In this work, the liquid pools are classified as being part of the "decomposing biomass". Because every liquid (compound) will have a certain vapor pressure, a rapid withdrawal of vapor compounds above these liquid pools will enhance evaporation (and thus reduce overall scission/(cross)-linking of the liquid). Liquid

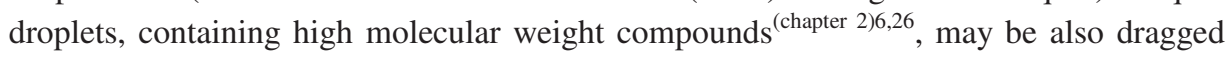
along with the vapor/gas stream as aerosol and end up in the pyrolysis oil fraction (physical entrainment).

\section{(Cross)-linking}

Molecular bonds are formed by linking reactions which can occur in the solid, liquid or on the boundary of the solid-liquid phase ${ }^{27}$. Cross-linking reactions are linking reactions in which 3 dimensional structure is formed. Examples of linking reactions are: addition reactions which lead to polymerization without overall formation of gas and vapors and polycondensation reactions which lead to polymerization of the "decomposing biomass" with simultaneous scission of gases/vapors.

Overall, (cross)-linking reactions are assumed to strengthen the 3D structure of the decomposing feedstock and thus favour char formation, while scission reactions are assumed to break up the 3D structure thereby diminishing char formation. The prevailing conditions are expected to influence the instantaneous ratio between scission and (cross)linking rate in each reaction step and therewith final oil, char and gas yields. For example, much higher char yields are obtained under slow pyrolysis conditions (slow heating rate, long vapor residence time) than under fast pyrolysis conditions (fast heating rate, short vapor residence time). Using our mechanism shown in Figure 3.1, the high char yield at slow heating rates can be explained by the fact that at low temperatures less volatiles can escape from the solid/liquid "decomposing biomass" by vaporization and sublimation. Consequently, the average residence time of compounds in the "decomposing biomass" is increasing leaving more time for (cross)-linking reactions. Furthermore, the overall ratio of (cross)-linking to scission is expected to increase with decreasing temperature ${ }^{33}$. Both effects will result in a high char yield under slow pyrolysis conditions. In addition vapor-solid interactions are expected to play a role as well, especially in the presence of minerals ${ }^{\text {(chapter } 4), 5}$. This is one example and the 
proposed mechanism will be further validated in this chapter by additional experimental results.

\subsection{Equipment and procedure}

\subsubsection{Feedstock and sample/mesh preparation procedure}

Lignocel 9 (pine, softwood, Rettenmaier \& Sohne GmbH, 4.0 $10^{2} \mathrm{ppm} \mathrm{K}$ ), $\mathrm{KCl}$ (Sigma, P9333, purity $>99.0 \%)$ impregnated Lignocel $9\left(6.5 \cdot 10^{3} \mathrm{ppm} \mathrm{K}^{5}\right.$, cellulose (fibrous long, Sigma C6663), xylan (from beech wood, $>90 \%$ xylose residues, ash content 8.5 wt\%, Sigma X-4252), lignin (organosolv, Sigma 371017), levoglucosan (99\%, Sigma $316555)$ and glucose $(99.5 \%$, Sigma G7528) were used as feedstock. Xylan was used as representative of hemicellulose. Their chemical composition, ash content and elemental composition are listed in Table 3.2. The molecular weight distribution of lignin was determined by $\mathrm{SEC}^{\text {(chapter }}{ }^{6) 34}$ (Figure 3.4D). This was not possible for the other compounds since they were not soluble in the mobile phase (THF). The degree of polymerization (dp) of cellulose was measured by ViskoTeepak (ASTM D 4243 method) and appeared to be 170 , which corresponds to a molecular weight of $25000 \mathrm{~g} / \mathrm{mol}$.

TGA analyses (STA 449F3 Netzsch, $\Phi_{\mathrm{v} . \mathrm{N} 2}=60 \mathrm{ml} / \mathrm{min}$ ) were carried out for all feedstocks to study their decomposition behaviour. The samples were heated from room temperature till $600{ }^{\circ} \mathrm{C}$ at a heating rate of $5{ }^{\circ} \mathrm{C} / \mathrm{min}$. The TGA-residues and temperatures at which a maximum weight loss rate was achieved are reported in Table 3.2.

Table 3.2 Properties of feedstocks

\begin{tabular}{|c|c|c|c|c|c|c|}
\hline & Lignocel 9 & Cellulose & Xylan & Lignin & Glucose & Levoglucosan \\
\hline Cellulose $\left(\mathrm{d}_{\mathrm{p}} \sim 170\right)\left[\mathrm{wt} \%_{\mathrm{dry}}\right]$ & 35 & $\sim 100$ & 0 & 0 & 0 & 0 \\
\hline Hemicellulose [wt $\left.\%_{\text {dry }}\right]$ & 29 & 0 & $>90$ & 0 & 0 & 0 \\
\hline Lignin $\left[\mathrm{wt} \%_{\mathrm{dry}}\right]$ & 28 & 0 & 0 & $\sim 100$ & 0 & 0 \\
\hline ash $\left[\mathrm{wt} \%_{\mathrm{dry}}\right]$ & 0,6 & 0,07 & 8,5 & 0,1 & 0 & 0 \\
\hline moisture [wt $\%]$ & 0,0 & 0,0 & 0,0 & 0,0 & 0,0 & 0,0 \\
\hline $\mathrm{C}\left[\mathrm{wt} \%_{\mathrm{dry}}\right]$ & 47,6 & 43,2 & 37,8 & 66,6 & 40,0 & 44,4 \\
\hline $\mathrm{H}[\mathrm{wt} \%$ dry $]$ & 5,9 & 6,3 & 5,7 & 6,1 & 6,7 & 6,2 \\
\hline $\mathrm{O}\left[\mathrm{wt} \%_{\mathrm{dry}}\right]$ & 45,7 & 50,5 & 48,0 & 27,1 & 53,3 & 49,3 \\
\hline $\mathrm{N}\left[\mathrm{wt} \%_{\mathrm{dry}}\right]$ & 0,20 & 0,0 & 0,02 & 0,14 & 0,0 & 0,0 \\
\hline TGA residue $\left[\mathrm{wt}_{\mathrm{dry}} \%\right]^{*}$ & 23 & 10 & 31 & 42 & 16 & 1 \\
\hline $\begin{array}{l}\mathrm{T} \text { at maximum } \\
\text { rate of mass loss }\left[{ }^{0} \mathrm{C}\right]^{*}\end{array}$ & 355 & 340 & 265 & 355 & 310 & 270 \\
\hline
\end{tabular}

${ }^{*}$ The samples were heated from room temperature till $600{ }^{\circ} \mathrm{C}$ at a heating rate of $5{ }^{\circ} \mathrm{C} / \mathrm{min}$ 
Lignocel 9, cellulose, xylan, lignin and levoglucosan wire-mesh samples were prepared according to a standard procedure ${ }^{\text {(chapter } 2) 6}$. About $0.05 \mathrm{~g}$ of dried $\left(24 \mathrm{~h}, 105{ }^{0} \mathrm{C}\right)$, powdered sample was pressed between two wire-meshes of 2.5 by $5 \mathrm{~cm}$ (Dinxperlo, Wire Weaving Co. Ltd., mesh 200, wire thickness $0.06 \cdot 0.06$ mm, twilled weave, AISI 316). The glucose samples were prepared according to a different method because it was not possible to uniformly distribute the glucose powder across the mesh. A glucose paste was prepared by first dissolving glucose in demi-water $(0.9 \mathrm{~g} / \mathrm{ml})$, heating the solution to 175 ${ }^{0} \mathrm{C}$ and keeping the solution at that temperature for 2 hours to partly evaporate the water. After cooling down to room temperature, the thick glucose paste was painted on one mesh and the other mesh was pressed on top of it. The complete sample was dried in an oven at $75{ }^{\circ} \mathrm{C}$ for 24 hours. HPLC data (Figure 3.6C) show the presence of glucose only, while the sample was still white after this procedure: both suggest that glucose remained intact.

\subsubsection{Set-Up: Wire-Mesh reactor}

The wire-mesh reactor and the experimental procedure are described in detail elsewhere ${ }^{\text {(chapter 2)6 }}$. Figure 3.2 shows the front- and side view of the wire-mesh reactor and the operating conditions are reported in Table 3.3. The mesh/feedstock (2) served as an electrical resistance heater and was placed inside a vacumized, liquid nitrogen (4) cooled vessel (1).

The temperature was varied by varying the length of the heating pulse (40-110 ms) and the set-temperature of the PID controller. Unless otherwise reported, the period the meshes were maintained at this temperature was $1 \mathrm{~s}$. This time is further referred to as the holding time. The heating rate of the mesh to the set-temperature could be varied between $50{ }^{0} \mathrm{C} / \mathrm{s}$ and $7000{ }^{0} \mathrm{C} / \mathrm{s}$. A few step-wise heating tests were carried out. In the stepwise pyrolysis experiment, the sample was heated till $300{ }^{0} \mathrm{C}$ at a heating rate of $\sim 7000{ }^{0} \mathrm{C} / \mathrm{s}$ after which a holding time of $1 \mathrm{~s}$ was applied. After cooling down to room temperature, a second heating pulse was given and the sample was heated at $\sim 7000{ }^{0} \mathrm{C} / \mathrm{s}$ till $500{ }^{\circ} \mathrm{C}$. Again, a holding time of $1 \mathrm{~s}$ was applied.

Table 3.3 Standard operating conditions

\begin{tabular}{|l|l|}
\hline $\mathrm{T}\left[{ }^{0} \mathrm{C}\right]$ & $250-700$ \\
\hline Heating rate $\left[{ }^{0} \mathrm{C} / \mathrm{s}\right]$ & $50-7000$ \\
\hline Feedstock loading $[\mathrm{g}]$ & $\sim 0.05$ \\
\hline Holding time $[\mathrm{s}]$ & $1(2$ experiments: $5 \mathrm{~s})$ \\
\hline $\mathrm{P}_{\text {initial }}[\mathrm{mbar}]$ & $\sim 0.0-0.3$ \\
\hline Number of experiments per data point & $>5$ \\
\hline
\end{tabular}




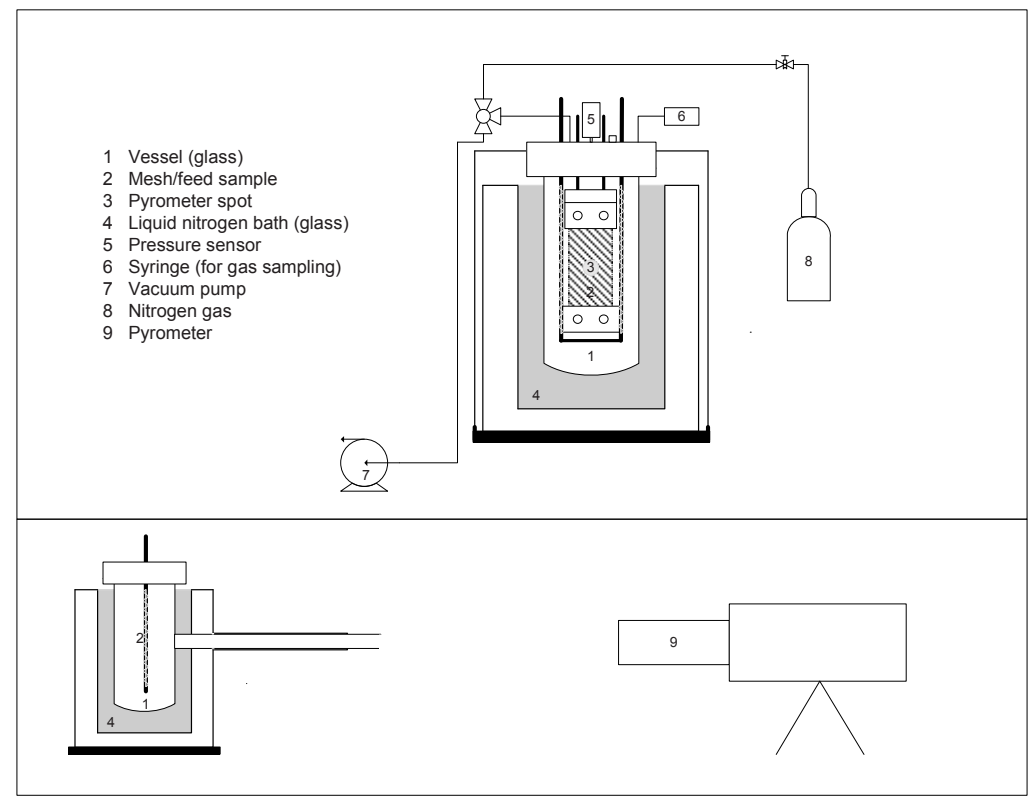

Figure 3.2 Scheme of wire mesh reactor. Top: front view Bottom: side view

\subsubsection{Analytics pyrolysis products: oil, gas and char}

Oil

The total amount of oil is defined as the sum of the oil collected on the tape/clamps $(5,6)$ and vessel (1) at room temperature. Size Exclusion Chromatography (SEC) coupled to a RID detector was used to obtain an indication of the molecular weight distribution of pyrolysis oil ${ }^{\text {(chapter } 6) 34}$. HPLC analyses were carried out to qualify the sugars (Agilent 1200 serie, PL Hi-PlexH (300•7.7 mm, part no PL 1170-6830) $65{ }^{\circ} \mathrm{C}$, RID $\left(55{ }^{\circ} \mathrm{C}\right) ; 0.6$ $\mathrm{ml} /{\left.\mathrm{min} 5 \mathrm{mM} \mathrm{H}_{2} \mathrm{SO}_{4}\right) \text {. 1-H-NMR }}^{\text {(chapter } 2) 6}$ spectra were interpreted by the classification in functional groups as suggested by Ingram et $\mathrm{al}^{35}$.

\section{$\underline{\mathrm{GaS}}$}

The gas samples (9) were analysed in a gas chromatograph ${ }^{\text {(chapter 2)6 }}$. The gas composition [mol\%] was calculated by normalizing the concentrations of $\mathrm{CO}, \mathrm{CO}_{2}, \mathrm{CH}_{4}$ and higher hydrocarbons $\left(\mathrm{C}_{2+}\right.$, being the sum of $\mathrm{C}_{2} \mathrm{H}_{4}, \mathrm{C}_{2} \mathrm{H}_{6}, \mathrm{C}_{3} \mathrm{H}_{6}$ and $\left.\mathrm{C}_{3} \mathrm{H}_{8}\right)$. In several experiments the gas yield was determined independently by using the difference between initial and final pressure, the ideal gas law, the molar weight of the gaseous compounds and the gas composition. For the other experiments the gas yield was determined by difference.

\section{$\underline{\text { Char }}$}

Char was defined as the material remaining between the meshes after an experiment (thus also incorporating possibly unconverted feedstock). Complete conversion is defined as 
the moment when all reactions are finished at a certain set-temperature; the char residue "decomposing biomass" doesn't change anymore. The char yield was determined gravimetrically ${ }^{\text {(chapter 2)6 }}$. The char was characterized by FTIR and SEM ${ }^{\text {(chapter 2)6 }}$. A THFsoluble fraction was extracted (ultrasonic bath, $\mathrm{T}=55^{\circ} \mathrm{C}$ ) from the char (and Lignocel 9). The molecular weight distribution of this fraction was determined using SEC coupled to a UV-detector ${ }^{\text {(chapter 6)34. }}$

\subsubsection{Validation}

The wire-mesh reactor has been extensively validated in an earlier publication ${ }^{\text {(chapter } 2) 6}$. The main findings are summarized below. The temperature distribution across the mesh was within $35^{\circ} \mathrm{C}$; the temperature of the measuring spot during the holding period could be controlled within $5{ }^{0} \mathrm{C}$. The mesh material appeared not to be catalytically active. Vapor residence times lower than 15-25 ms were achieved. Experiments needed to be carried out at least 5 times to obtain a reliable value for the oil $\left( \pm 4 \mathrm{wt} \%^{[2]}\right)$, char $( \pm 1$ $\left.\mathrm{wt} \%^{[1]}\right)$ and measured gas yield $\left( \pm 1 \mathrm{wt} \%^{[3]}\right)$. Mass balance closures between 90 and 110 wt $\%$ were obtained. It should be noted that the compounds which were volatile at room temperature were included in the gas yield. Reproducible results concerning oil (SEC, NMR), gas (GC) and char (FTIR) composition were obtained.

\subsection{Results}

\subsubsection{Model Compounds: cellulose, lignin, xylan}

Lignocellulosic biomass consists mainly of cellulose, hemicellulose and lignin. Cellulose is a polysaccharide, consisting of a linear chain of $\beta(1 \rightarrow 4)$ linked D-glucopyranose units $^{1}$. Hemicellulose is a non linear polysaccharide consisting of various monosaccharides (e.g. mannose, xylose) ${ }^{1}$. Lignin is a three-dimensional, highly branched, polyphenolic substance that consists of variously bonded "hydroxyl-" and "methoxy" substituted phenylpropane units ${ }^{1}$. The nature of biomass extracted lignin and hemicellulose is dependent on the type of biomass ${ }^{1,10}$, but also on the extraction method $^{10,36}$. In this section we are discussing the results obtained using cellulose with a $\mathrm{dp}, \mathrm{w}$ of 170, xylan from beechwood containing $8.5 \mathrm{wt} \%$ ash as model compound for hemicellulose and organosolv lignin (see Table 3.2 for properties). The results are shown in Figure 3.3 (yields; heating rate $\left.>6000{ }^{0} \mathrm{C} / \mathrm{s}\right)$, Figure 3.4A $\left(\mathrm{M}_{\mathrm{w}}\right.$-distribution), Figure 3.6A (HPLC, cellulose) and Table 3.4 (NMR). The results obtained for Lignocel 9 are shown as reference ${ }^{(\text {chapter } 2) 6}$.

\footnotetext{
${ }^{[2]} 90 \%$ CI for 5 measurements

${ }^{[3]}$ stdev based on 10 measurements
} 


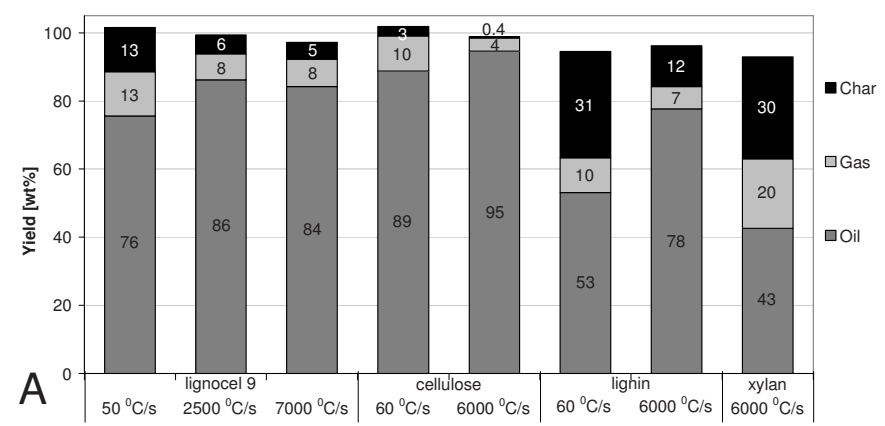

A) oil, char, total gas yield

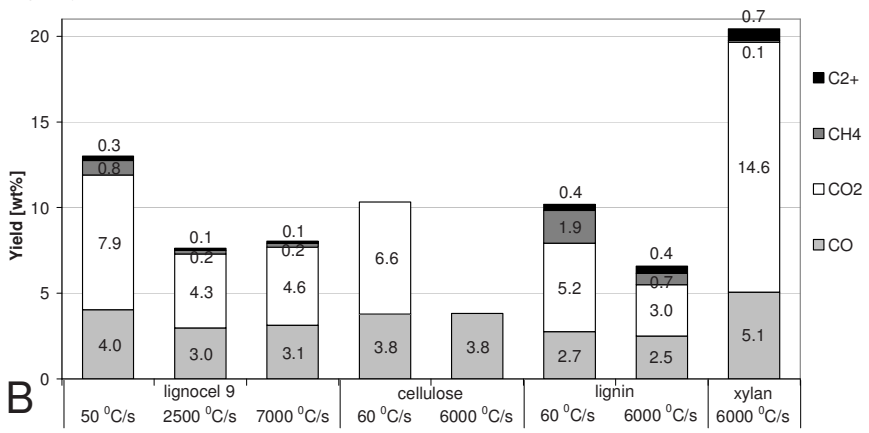

B) Yields individual gas compounds; , gas yield measured independently

Figure 3.3 Results for model compounds and Lignocel 9 (holding time $1 \mathrm{~s}$ ) A) oil, char, total gas yield

For cellulose, an oil yield of $95 \mathrm{wt} \%$, a gas yield of $4 \mathrm{wt} \%$ and virtually no char $(0.4$ wt\%) was obtained (Figure 3.3A). Apparently, (cross)-linking reactions resulting in char do not play a significant role under the extreme conditions in our wire-mesh reactor $\left(\tau_{\text {vapors }}<15-25 \mathrm{~ms}^{6}\right.$, heating rate $\left.6000{ }^{0} \mathrm{C} / \mathrm{s}\right)$ and cellulose is (almost) completely volatilized. In contrast, in the corresponding TGA experiment in which a heating rate of only $5{ }^{\circ} \mathrm{C} / \mathrm{min}$ was used, a char residue of $10 \mathrm{wt} \%$ remained (Table 3.2). The production of some char, although a low amount (2-3 wt\%), was also observed in previous studies using wire-mesh reactors (e.g. heating rate $1100{ }^{\circ} \mathrm{C} / \mathrm{s}$ ) ${ }^{37,38}$. In line with our data, virtually no char was obtained by Boutin et al. ${ }^{28}$ using a radiant beam to heat the cellulose (calculated heating rate $\sim 1600{ }^{\circ} \mathrm{C} / \mathrm{s}^{28}$ ). Remarkably, in our experiments the produced gas only contained $\mathrm{CO}$ (Figure 3.3B). To the best of our knowledge, we are the first to observe the formation of only $\mathrm{CO}$ during the thermochemical decomposition of cellulose. Typically $\mathrm{CO}_{2}$ is reported to be produced during the early stage of cellulose pyrolysis ${ }^{37,39}$. Levoglucosan is known to be an important fast pyrolysis product of cellulose ${ }^{27,39-41}$; in literature yields up to $70 \mathrm{wt} \%{ }^{27}$ are reported. Levoglucosan was indeed detected inside the oil (HPLC), but also various larger sugars were identified (Figure 3.6A). These sugars were also detected inside the oil from Lignocel 9 (Figure 3.6A) and may thus originate from the cellulose in it. The boiling points of levoglucosan, cellobiosan and cellotriosan 
are reported to be $\sim 300,580$ and $790{ }^{0} \mathrm{C}$ respectively ${ }^{27}$. Based on our mechanism postulated in Figure 3.1 large sugars are expected to be able to vaporize in our experiments because of a rapid removal of vapors by deep vacuum $(<0.3 \mathrm{mbar})$. So, these large sugars are expected to have escaped from the cellulose matrix before either scission reactions to smaller molecules (like levoglucosan) or (cross)-linking reactions to char could take place.

Although lignin was not completely volatilized in our set-up, still a very high oil (78 wt $\%$ ) and low char (12 wt \%) yield was obtained. To the best of our knowledge, nobody obtained such high oil yields from lignin before (Figure 3.3A). Typical oil yields from lignin using fluidized bed and entrained flow reactors are between 20 and $50 \mathrm{wt} \%$ (Round Robin test from 2010) ${ }^{30}$. However, also in another, differently configured, wire-mesh reactor an oil yield of only $55 \mathrm{wt} \%{ }^{42}$ was obtained. The fact that a TGA residue (char) of $42 \mathrm{wt} \%$ was obtained (Table 3.2) shows that the type of lignin we used for our experiment would have been charred under "more conventional" pyrolysis conditions. In section 3.4.3, the proposed mechanism will be used to explain this high oil yield. A mixture of gases with a total yield of $12 \mathrm{wt} \%$ was produced during the pyrolysis of lignin. Compared to the pyrolysis of cellulose, xylan and Lignocel 9 the methane yield (2 wt $\%$ ) was high (Figure 3.3B).

The pyrolysis of xylan gave unexpected low oil (43 wt \%), high char (30 wt \%) and high gas yields $\left(20 \mathrm{wt} \%\right.$, Figure 3.3A). About half of the produced gases consisted of $\mathrm{CO}_{2}$ (Figure 3.3B). The char yield was even similar as obtained in the corresponding TGA experiment, despite the huge difference in experimental conditions. It should be noted that the ash content of the xylan used was very high (8.5 wt $\%)$. Patwardhan et al. ${ }^{36}$ used the same xylan in their Py-GC/MS experiments, resulting in $28 \mathrm{wt} \%$ char which is similar to the char yield obtained in this study. They also performed an experiment in which they removed the majority of the minerals from the xylan. The char yield decreased from 28 wt $\%$ to $13 \mathrm{wt} \%$ in that case. Based on the results of Patwardhan et al. ${ }^{36}$ and our results concerning the potassium content in biomass (section 3.4.5) the high char yield is likely to be caused by (very fast) mineral catalyzed (cross)-linking reactions.

The molecular weight distributions of the oils produced from cellulose, lignin, xylan and Lignocel 9 are shown in Figure 3.4A and the corresponding NMR data in Table 3.4. The oil from lignin did contain the highest concentration of aromatics (10.0-6.8 ppm/ UV/RID ratio), while the oil from lignin and xylan contained the highest concentration of alkane like structures (0-2.2 ppm). The lowest average molecular weight was observed for the oil originating from cellulose $(\mathrm{dp}, \mathrm{w}=170,25000 \mathrm{~g} / \mathrm{mol})$. This and the negligible char yield show that (cross)-link/polymerization reactions were not important during the cellulose experiments. Despite the high char yield from xylan, only a slightly higher average 
molecular weight was observed in that case. Significant higher molecular weight compounds were observed in the oil from lignin. The highest observed molecular weights in the oil of lignin and the lignin feedstock were similar. (Figure 3.4D). It is remarkable that the high molecular weight compounds present in the oil from lignin were absent in the oil from pine wood (Lignocel 9), while $28 \mathrm{wt} \%$ of lignin was present. Although another type of lignin was present in pine wood than used as model compound, these results suggest that interactions between hemicellulose, cellulose and lignin took place in the "decomposing biomass".

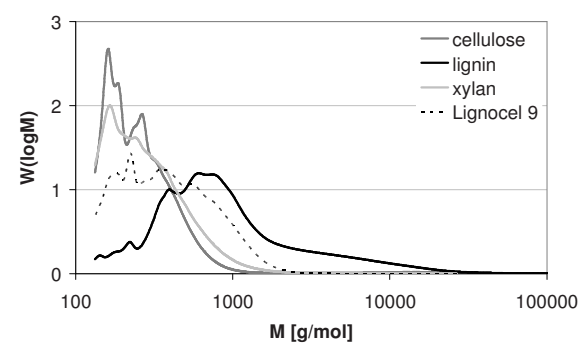

A) Pyrolysis oil from different model compounds $\left(\mathrm{T}=500{ }^{\circ} \mathrm{C}\right.$, holding time $=1 \mathrm{~s}$, heating rate $\left.6000-7000{ }^{\circ} \mathrm{C} / \mathrm{s}\right)$

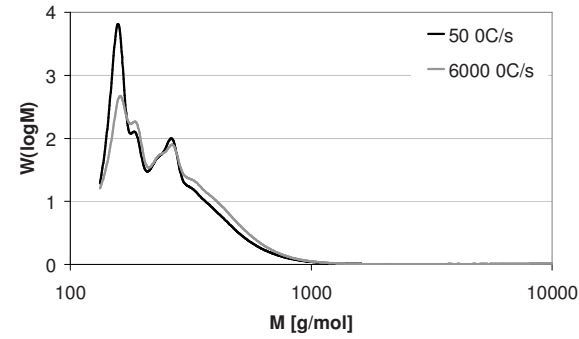

C) Effect heating rate on pyrolysis oil from cellulose $\left(\mathrm{T}=500{ }^{\circ} \mathrm{C}\right.$, holding time $\left.=1 \mathrm{~s}\right)$

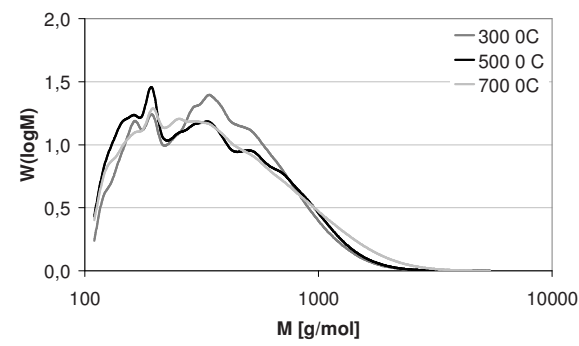

E) Effect $\mathrm{T}$ on pyrolysis oil from Lignocel 9 (holding time $=1 \mathrm{~s}$, heating rate $=7000^{\circ} \mathrm{C} / \mathrm{s}$ )

Figure 3.4 $\mathrm{M}_{\mathrm{w}}$ distributions

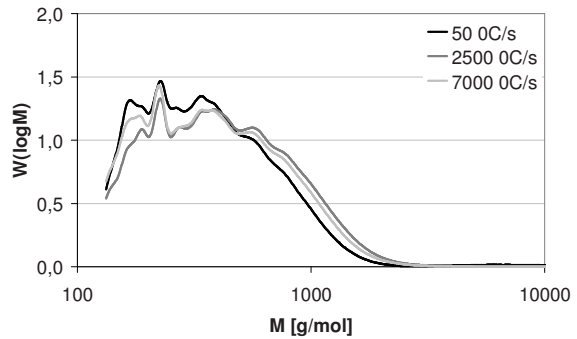

B) Effect heating rate on pyrolysis oil from Lignocel 9 $\left(\mathrm{T}=500{ }^{\circ} \mathrm{C}\right.$, holding time $\left.=1 \mathrm{~s}\right)$

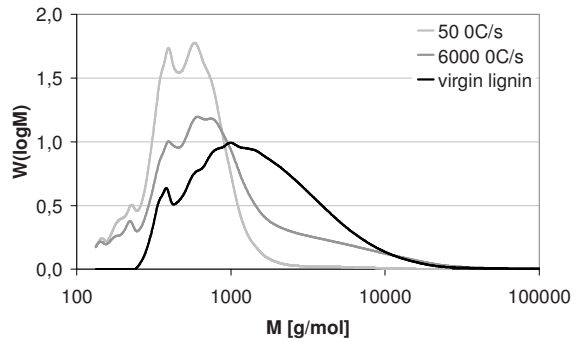

D) Effect heating rate on pyrolysis oil from lignin ( $\mathrm{T}=500{ }^{\circ} \mathrm{C}$, holding time $\left.=1 \mathrm{~s}\right)$

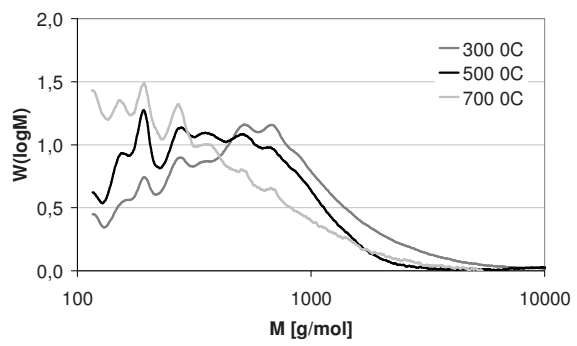

F) THF extracted fraction of char produced at 3 temperatures (holding time $=1 \mathrm{~s}$, heating rate $=7000{ }^{\circ} \mathrm{C} / \mathrm{s}$ ) 


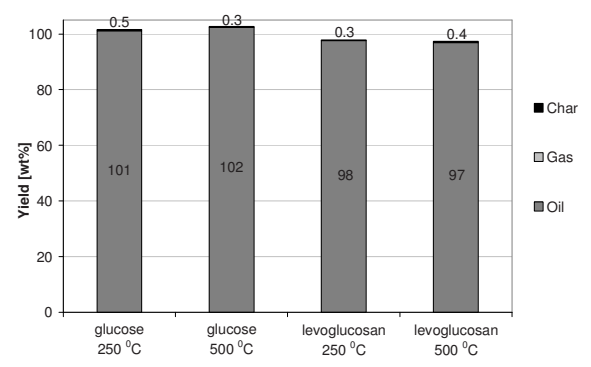

Figure 3.5 Oil, char and gas yield mono-sugars; gas yield measured independently (holding time $1 \mathrm{~s}$, heating rate $=6000{ }^{\circ} \mathrm{C} / \mathrm{s}$ )

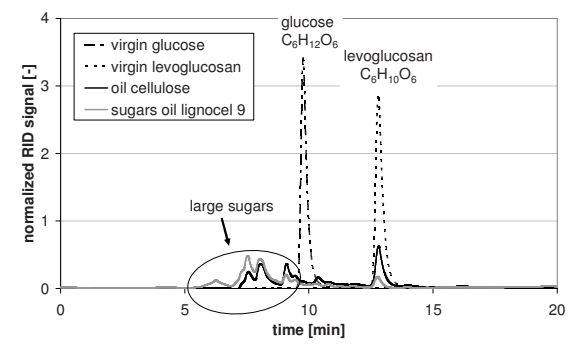

A) cellulose and sugars from Lignocel 9

$\left(\mathrm{T}=500{ }^{\circ} \mathrm{C}\right.$, heating rate $\left.6000-7000{ }^{\circ} \mathrm{C} / \mathrm{s}\right)$

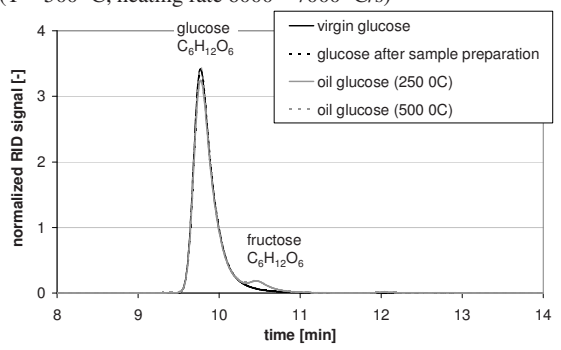

C) glucose

(holding time $1 \mathrm{~s}$, heating rate $6000{ }^{\circ} \mathrm{C} / \mathrm{s}$ )

Figure 3.6 HPLC analysis of the sugars (area normalized to 1)

\subsubsection{Mono-sugars: glucose, levoglucosan}

From the TGA experiments, it is evident that glucose has a much larger tendency to form char than levoglucosan (Table 3.2). Besides the difference in intrinsic reactivity of these compounds, this also might be related to the higher vapor pressure of levoglucosan compared to glucose $\left(\sim 450 \text { times at } 130{ }^{\circ} \mathrm{C}\right)^{43}$. Because of this, levoglucosan molecules are expected to escape more easily from the "decomposing levoglucosan" than glucose molecules from the "decomposing glucose" thereby preventing (cross)-linking/charring reactions at higher temperatures. Although cracking and polymerization reactions are reported to take place upon pyrolysis of levoglucosan ${ }^{39,41}$, recently Patwardhan ${ }^{40}$ completely vaporized/sublimated levoglucosan in a Py-GC/MS (heating rate $>2000$ ${ }^{0} \mathrm{C} / \mathrm{S}$ ). On the other hand, when pyrolysing glucose these researchers obtained almost 10 
wt\% char and a wide range of products (e.g. formic acid, glycoaldehyde, 2-furaldehyde, 5-hydroxymethyl furfural, levoglucosan).

In the wire mesh reactor virtually only "oil" was formed during the pyrolysis experiments carried out with levoglucosan and glucose. No yield differences were observed between the experiments carried out at 250 and $500{ }^{0} \mathrm{C}$ (Figure 3.5). In all cases the "oil" consisted of a white solid layer. Using levoglucosan as feedstock no other product than levoglucosan could be detected in the "oil" on the vessel wall (HPLC). For the glucose feedstock, the large majority of the "oil" consisted of glucose, with about 8 wt $\%$ of fructose (isomer glucose; wt $\%$ based on equal RID response factors). Considering the virtual absence of both char and other reactions products, the decomposition reactions appear to be even more efficiently suppressed in our wire mesh reactor than in a Py$\mathrm{GC} \mathrm{MS}^{40}$ that is often used to study the "primary" pyrolysis reactions ${ }^{44}$. The results imply that if mono-sugars are formed during pyrolysis reactions of wood (constituents) in our set-up these would be able to escape from the (decomposing) biomass matrix without reacting further. Consequently, the absence of glucose in the oil from cellulose and Lignocel 9 (Figure 3.6) suggests that glucose is not formed during the decomposition of those feedstocks. This is in line with other researchers, who report that levoglucosan is formed during the pyrolysis of cellulose and wood which can be converted to glucose after a subsequent hydrolysis step ${ }^{45,46}$.

Table 3.4 NMR results

\begin{tabular}{|c|c|c|c|c|c|c|c|}
\hline \multirow{2}{*}{ ppm } & \multirow{2}{*}{ Functional Groups } & \multicolumn{3}{|c|}{ Lignocel 9} & \multirow{2}{*}{$\begin{array}{c}\text { Cellulose } \\
500{ }^{0} \mathrm{C}\end{array}$} & \multirow{2}{*}{$\begin{array}{l}\text { Lignin } \\
500{ }^{0} \mathrm{C}\end{array}$} & \multirow{2}{*}{$\begin{array}{c}\text { Hemicellulose } \\
500{ }^{0} \mathrm{C}\end{array}$} \\
\hline & & $300^{\circ} \mathrm{C}$ & $500{ }^{0} \mathrm{C}$ & $700{ }^{0} \mathrm{C}$ & & & \\
\hline $10.0-8.0$ & $\begin{array}{l}-\mathrm{CHO}-\mathrm{COOH} \\
\text { downfield } \mathrm{ArH}\end{array}$ & 0.0 & 1.2 & 1.4 & 1.2 & 3.3 & 0.1 \\
\hline $8.0-6.8$ & ArHHC=C (conjugated) & 0.3 & 3.0 & 3.0 & 1.5 & 4.6 & 0.3 \\
\hline $6.8-6.4$ & $\mathrm{HC}=\mathrm{C}$ (non conjugated) & 0.6 & 3.5 & 3.5 & 2.0 & 4.7 & 1.5 \\
\hline $6.4-4.2$ & $\begin{array}{c}\text { ¿CHO } \mathrm{ArOH} \\
\mathrm{HC}=\mathrm{C} \text { (non conjugated) }\end{array}$ & 1.7 & 17.0 & 15.7 & 27.6 & 0.5 & 7.8 \\
\hline $4.2-3.0$ & $\mathrm{CH}_{3} \mathrm{O}--\mathrm{CH}_{2} \mathrm{O}-{ }^{-} \mathrm{CHO}$ & 93.2 & 63.1 & 64.7 & 60.9 & 59.1 & 53.2 \\
\hline $3.0-2.2$ & $\mathrm{CH}_{3} \stackrel{\mathrm{O}}{\mathrm{C}}-\mathrm{CH}_{3} \mathrm{Ar}-\mathrm{CH}_{2} \mathrm{Ar}$ & 1.8 & 5.7 & 4.3 & 3.8 & 11.5 & 16.3 \\
\hline $2.2-1.6$ & $-\mathrm{CH}_{2}-$ aliphatic $\mathrm{OH}$ & 1.1 & 4.1 & 4.3 & 1.9 & 5.9 & 10.7 \\
\hline $1.6-0.0$ & $-\mathrm{CH}_{3}-\mathrm{CH}_{2}-$ & 1.3 & 2.4 & 3.2 & 1.1 & 10.3 & 10.0 \\
\hline (linked & $\begin{array}{l}\text { EC: UV/RID•100 } \\
\text { aromatic and conjugated } \\
\text { uble bond content) }\end{array}$ & 9.0 & 12.0 & 12.1 & 6.8 & 15.0 & 11.2 \\
\hline
\end{tabular}




\subsubsection{Effect of heating rate}

Only a few type of pyrolysis set-ups possess the possibility to vary the heating rate among which: fixed bed reactors ${ }^{47}$, heating by a lamp ${ }^{28,48}$, TGA's ${ }^{44,49}$ and wire-mesh reactors $^{37,38,50-53}$. Another possibility to vary the heating rate is by using particles with different sizes ${ }^{3,54}$. However, not only is the heating rate varied when using larger particles, but also the transport of vapors/aerosols/gases out of the particle. An indication about the achievable heating rate ranges is shown in Figure 3.7. Wire-mesh reactors are suitable for studying a wide range of heating rates, even up to $10.000{ }^{\circ} \mathrm{C} / \mathrm{s}$. It is reported that fast heating rates are required to obtain high oil yields (fast pyrolysis) ${ }^{1-3}$ and slow heating rates to obtain high char yields (slow pyrolysis) ${ }^{1}$. Contradictory to the general trend reported in literature, some researchers using wire mesh reactors report an increase in "char" yield with heating rate. However, these researchers did not apply any additional holding time ${ }^{37,38,50}$, and the reported effect is expected to arise because of incomplete sample conversion at high heating rates. At high heating rates less time is needed to reach the set temperature and thus available to realize complete sample conversion.

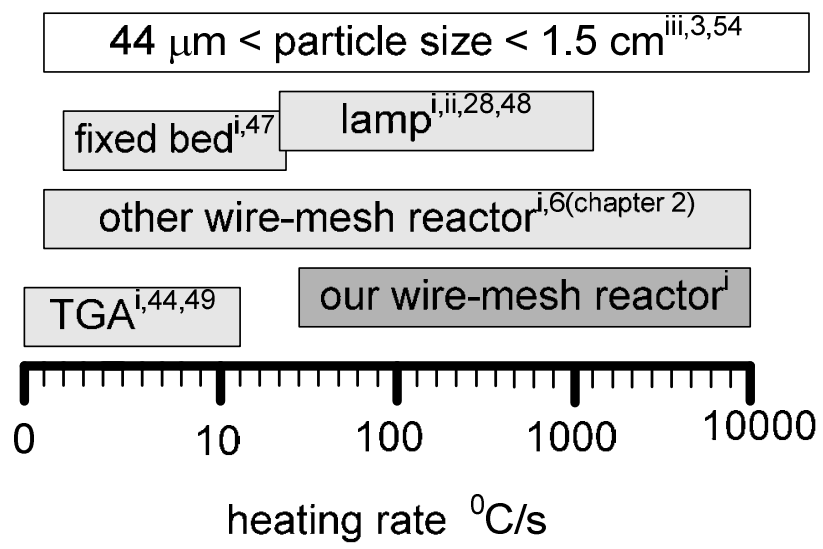

Figure 3.7 Indication typical heating rates

$\mathrm{i}$ heating rate reactor, actual heating rate biomass will be lower due to heat transfer limitations

$\mathrm{ii}=$ heat flux between $80-18000 \mathrm{~kW} / \mathrm{m}^{2}$

iii average heating rate slab obtained by solving the instationary heat balance for a slab, endothermic heat of reaction neglected, required data for the skeletal density, heat conductivity and heat capacity were taken from Kersten et $\mathrm{al}^{3}$

In our wire-mesh reactor, we studied the effect of heating rate, which was varied between $50{ }^{\circ} \mathrm{C} / \mathrm{s}$ and $7000{ }^{\circ} \mathrm{C} / \mathrm{s}$. After reaching the set-temperature, an additional holding time of 1 $\mathrm{S}$ was used to achieve complete conversion ${ }^{6}$. A heating rate of $50{ }^{0} \mathrm{C} / \mathrm{s}$ corresponds approximately with the average heating rate of a $2 \mathrm{~mm}$ particle from 20 till $490{ }^{\circ} \mathrm{C}$ inside a fluidized bed reactor operated at $500{ }^{\circ} \mathrm{C}$. Lignocel 9, cellulose and lignin were used as feedstock. The resulting yields are reported in Figure 3.3 and the molecular weight distributions in Figure 3.4B-D. 
For Lignocel 9 a decline in oil yield (- $8 \mathrm{wt} \%)$ and an increase in gas $(+5 \mathrm{wt} \%)$ and char yield $(+8 \mathrm{wt} \%)$ was observed when reducing the heating rate from $7000{ }^{0} \mathrm{C} / \mathrm{s}$ to $50{ }^{0} \mathrm{C} / \mathrm{s}$ (Figure 3.3A). The increase in char and gas yield were actually larger than the measured decrease in oil yield. This is due to measurement errors, particularly in the oil yield as explained in section 3.3.4. $\mathrm{CO}_{2}$ accounts for about three quarters of the increase in gas yield (Figure 3.3B). The average molecular weight of the oil produced at $7000{ }^{0} \mathrm{C} / \mathrm{s}$ is higher than the oil produced at $50{ }^{\circ} \mathrm{C} / \mathrm{s}$ (Figure 3.4B). No significant differences in results were observed between the experiments carried out at 2500 and $7000{ }^{\circ} \mathrm{C} / \mathrm{s}$ (Figure 3.3 and Figure 3.4B). The increase in $\mathrm{CO}_{2}$ yield with decreasing heating rate appears to be contradictory to previous results obtained in the same reactor ${ }^{\text {(chapter 2)6 }}$. These showed that the yield of $\mathrm{CO}$ (and not so much $\mathrm{CO}_{2}$ ) increased with increasing biomass loading and thus decreasing heating rate. However, the calculated lowest average heating rate (i.e. highest biomass loading) in that case was still $\sim 4600{ }^{0} \mathrm{C} / \mathrm{s}^{\text {(chapter 2)6 }}$. This is in between the tested 2500 and $7000{ }^{\circ} \mathrm{C} / \mathrm{s}$ for which no effect of heating rate was observed in this study. Our data suggest that (additional) $\mathrm{CO}$ is especially formed during vapor cracking reactions inside the biomass layer, while $\mathrm{CO}_{2}$ is formed at lower temperatures directly from the solid/liquid "decomposing biomass". In accordance with these data, we observed an increase in $\mathrm{CO}$ in our fluidized bed reactor when enlarging the vapor residence time, while the yield of $\mathrm{CO}_{2}$ increased only marginally ${ }^{(\text {chapter } 4) 5}$.

For cellulose and a low heating rate of $60{ }^{\circ} \mathrm{C} / \mathrm{s}$, the oil yield was still nearly $90 \mathrm{wt} \%$ and the char yield only $3 \mathrm{wt} \%$. The $\mathrm{CO}$ yield was similar as the one obtained at high heating rates $\left(6000{ }^{\circ} \mathrm{C} / \mathrm{s}\right)$. However, in this case $\mathrm{CO}_{2}$ was produced $(\sim 6.6 \mathrm{wt} \%)$, while no $\mathrm{CO}_{2}$ was observed at $6000{ }^{0} \mathrm{C} / \mathrm{s}$ (section 3.4.1). The average molecular weight of the oil appeared to be marginally higher at $6000{ }^{0} \mathrm{C} / \mathrm{s}$ compared to $60{ }^{0} \mathrm{C} / \mathrm{s}$ (Figure $3.4 \mathrm{C}$ ).

A much higher influence of the heating rate was observed upon the pyrolysis of lignin: the char yield increased from $12 \mathrm{wt} \%$ till $31 \mathrm{wt} \%$. The gas yield increased $+3 \mathrm{wt} \%$ and the oil yield decreased $-25 \mathrm{wt} \%$. Again the increase in gas yield was mainly due to $\mathrm{CO}_{2}$ formation. Figure 3.4D shows that the average molecular weight of the oil produced at 60 ${ }^{0} \mathrm{C} / \mathrm{s}$ is significantly lower than the oil produced at $6000{ }^{0} \mathrm{C} / \mathrm{s}$. The highest molecular weight compounds as present in the oil produced at $6000{ }^{0} \mathrm{C} / \mathrm{s}$ were even completely absent in the oil produced at $60{ }^{\circ} \mathrm{C} / \mathrm{s}$

In step-wise pyrolysis, the sample is subsequently exposed to increasing set-temperatures. We carried out a two step experiment: $1 \mathrm{~s}$ at $300{ }^{\circ} \mathrm{C}$ plus $1 \mathrm{~s}$ at $500{ }^{0} \mathrm{C}$ (see section 3.3.2 for details). The sample is exposed to relatively low temperature for prolonged time as compared to the standard experiment. Therefore the results are expected to have some resemblance to those of the slow heating rate experiments. The total char yield obtained after both steps was determined for lignin and Lignocel 9 and the values are reported in 
Table 3.5. The char yield of Lignocel 9 for the stepwise pyrolysis experiment was slightly higher $(+3 \mathrm{wt} \%)$ than for the standard experiment but lower $(-5 \mathrm{wt} \%)$ than for the experiment carried out at the slowest heating rate of $50{ }^{\circ} \mathrm{C} / \mathrm{s}$. These observations are in line with recently published data of Westerhof ${ }^{55}$ et al. about step-wise pyrolysis of Lignocel 9 (same as our feedstock) in a fluidized bed reactor. A similar trend in char yield was observed when using lignin as feedstock. The char yields for the standard experiment, stepwise pyrolysis experiment and the experiment using a low heating rate of $60{ }^{0} \mathrm{C} / \mathrm{s}$ were $12 \mathrm{wt} \%, 14 \mathrm{wt} \%$ and $31 \mathrm{wt} \%$, respectively. A higher intermediate temperature or longer holding time are expected to give higher char yields for lignin in the stepwise experiment.

Table 3.5 Char yield for some additional experiments

\begin{tabular}{|c|c|c|c|}
\hline & $\begin{array}{c}5000 \mathrm{ppm} \mathrm{K} \\
\text { Lignocel 9 }\end{array}$ & $\begin{array}{c}\text { Stepwise Pyrolysis*: } \\
\text { Lignocel 9 }\end{array}$ & $\begin{array}{c}\text { Stepwise Pyrolysis*: } \\
\text { Lignin }\end{array}$ \\
\hline Char yield [wt\%] & 10 & 8 & 14 \\
\hline \multicolumn{2}{|c|}{ Intermediate temperature $=300^{\circ} \mathrm{C}$, final temperature $=500^{\circ} \mathrm{C}$}
\end{tabular}

In summary, for Lignocel 9, cellulose and lignin a decline in oil yield and an increase in gas (especially $\mathrm{CO}_{2}$ ) and char yield were observed when the heating rate was decreased from 7000 to $50{ }^{0} \mathrm{C} / \mathrm{s}$. In addition, a higher average molecular weight was observed for the higher heating rate. The largest effect was observed during the pyrolysis of lignin. The effect of heating rate can be interpreted by means of the effect of temperature and "decomposing biomass" residence time. In line with our postulated mechanism in section 3.2.2, there are two explanations for these observations. At first, because of (on average) higher activation energy for scission than (cross)-linking reactions ${ }^{33}$, the overall ratio of scission to (cross)-linking is expected to increase with decreasing heating rate. Indeed higher char yields were observed at lower heating rates. Secondly, high temperatures, that are quickly reached for high heating rates, are favourable for efficient evaporation/sublimation of liquids/solids, thereby removing them from a zone where (cross)-linking reactions in the "decomposing biomass" (solid, liquid) can take place.

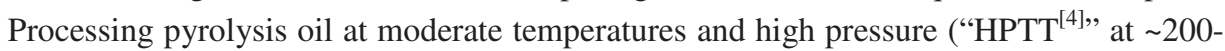
$300{ }^{\circ} \mathrm{C}, \mathrm{P} \sim 200-250$ bar) has shown that in the liquid phase (comparable to liquid pools in "decomposing biomass") extensive polymerization and char formation occurs very fast $^{56}$. The increase in average molecular weight with increasing heating rate can also be explained with the proposed mechanism. Larger molecules escape more easily from the "decomposing biomass" by vaporization/sublimation at higher temperatures ${ }^{26,57}$ preventing them to (cross)-link to solids. The high molecular weight compounds present in the oil produced from lignin at $6000{ }^{\circ} \mathrm{C} / \mathrm{s}$ are likely to be (cross)-linked to char at the lower heating rate $\left(60{ }^{0} \mathrm{C} / \mathrm{s}\right)$.

${ }^{[4]}$ HPTT stands for High Pressure Thermal Treatment 


\subsubsection{Effect of temperature}

For conventional fast pyrolysis processes (e.g. fluidized bed, fixed bed, ablative) a maximum oil yield is obtained between 400 and $550{ }^{\circ} \mathrm{C}^{2,3,58,59}$. For example, a maximum oil yield of $58 \mathrm{wt} \%$ was obtained for our feedstock, Lignocel 9, in a fluidized bed reactor $^{58}$. The gas yield (especially CO) is reported to increase above this temperature range ${ }^{3,58,59}$. The average molecular weight of the oil is reported to initially increase with increasing temperature till $\sim 500{ }^{\circ} \mathrm{C}$ and to decrease hereafter: vapor molecules appear to be cracked into smaller ones above $500{ }^{0} \mathrm{C}^{58}$. In other wire mesh studies two different trends concerning the oil yield are observed upon increasing the pyrolysis temperature.

1. Typical: a maximum oil yield at $\sim 500{ }^{0} \mathrm{C}$ is observed ${ }^{50,60-62}$. Above this temperature, the oil yield dropped considerably, while the gas yield increased (especially $\mathrm{CO}^{60,62}$ )

2. A-typical: the oil yield increases with temperature towards an asymptote (reached above $\left.\sim 500{ }^{0} \mathrm{C}\right)^{51-53,63}$

Experiments were carried out in the wire-mesh reactor using set-temperatures between $250{ }^{\circ} \mathrm{C}$ and $700{ }^{0} \mathrm{C}$ and a holding time of $1 \mathrm{~s}$. In addition, two experiments with a temperature of approximately $300{ }^{0} \mathrm{C}$ were carried out at a holding time of $5 \mathrm{~s}$. The heating rate was $\sim 7000{ }^{\circ} \mathrm{C} / \mathrm{s}$ in all cases.

Figure 3.8A shows a sharp increase in 'char' yield between 450 and $250{ }^{\circ} \mathrm{C}$, which is to a large extent caused by incomplete conversion of Lignocel 9 at low temperatures and holding times of $1-5 \mathrm{~s}$. The char yield $(5 \mathrm{wt} \%)$ remained constant above $500{ }^{0} \mathrm{C}$. The FTIR chromatogram of 'char' produced at $300{ }^{\circ} \mathrm{C}$ is comparable with the one from the feedstock (Figure 3.9). The peak around $1020 \mathrm{~cm}^{-1}(\mathrm{v}(\mathrm{C}-\mathrm{O}))$ disappeared for higher temperatures.

An optimum in oil yield (84wt\%) around $450{ }^{\circ} \mathrm{C}-550{ }^{\circ} \mathrm{C}$ was observed in the wire mesh reactor (Figure 3.8A), which is a similar temperature range as for more conventional setups. An increase in gas yield at the expense of a decrease in oil yield was observed above this temperature, but at $700{ }^{0} \mathrm{C}$ the oil yield was still $60 \mathrm{wt} \%$, which is extremely high. For example, under gasification conditions $\left(750-900{ }^{\circ} \mathrm{C}\right.$, long vapor residence times) the oil yield is reported to be only $5 \mathrm{wt} \%$ and the gas yield $85 \mathrm{wt} \%{ }^{2}$. The gas yields of the individual compounds were estimated using the gas composition and total gas yield trend line. With an increase in temperature, the gas composition contained more $\mathrm{CO}, \mathrm{CH}_{4}$ and higher $\mathrm{C}_{2+}$ at the expense of $\mathrm{CO}_{2}$ (Figure 3.8B). The $\mathrm{CO}_{2}$ yield appeared to go through a maximum, while the $\mathrm{CO}, \mathrm{CH}_{4}$ and $\mathrm{C}_{2+}$ yield increased (Figure 3.8C). 
We did not observe an asymptotic value for the oil yield upon increasing the temperature as observed in some other wire-mesh reactors ${ }^{51-53,63}$. It should be noticed that our optimum oil yield of $\sim 84 \mathrm{wt} \%$ is significantly higher than the reported asymptotic values which were always below $60 \mathrm{wt} \%^{51-53,63}$. Especially higher gas yields were observed in those studies, so the extent of vapor phase reactions is expected to be lower in our set-up. From our and literature data, it cannot be concluded if the decline in oil yield above 450$550{ }^{0} \mathrm{C}$ is caused predominantly by rigorous scission reactions in the "decomposing biomass" itself or by cracking reactions of vapors to gases inside the sample or in its immediate neighbourhood.
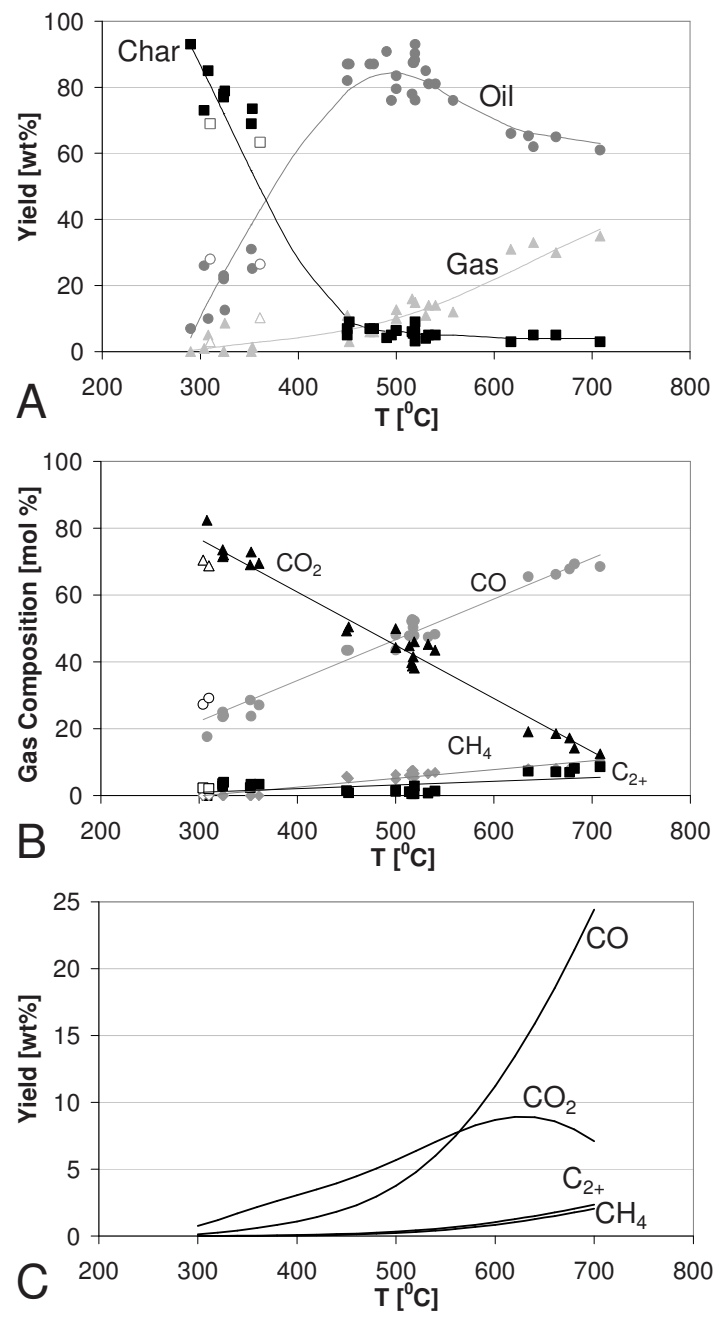

Figure 3.8 Effect temperature, gas yield calculated by difference (holding time $1 \mathrm{~s}$, non filled data point $=5 \mathrm{~s}$, heating rate $=7000{ }^{\circ} \mathrm{C} / \mathrm{s}$ ) 


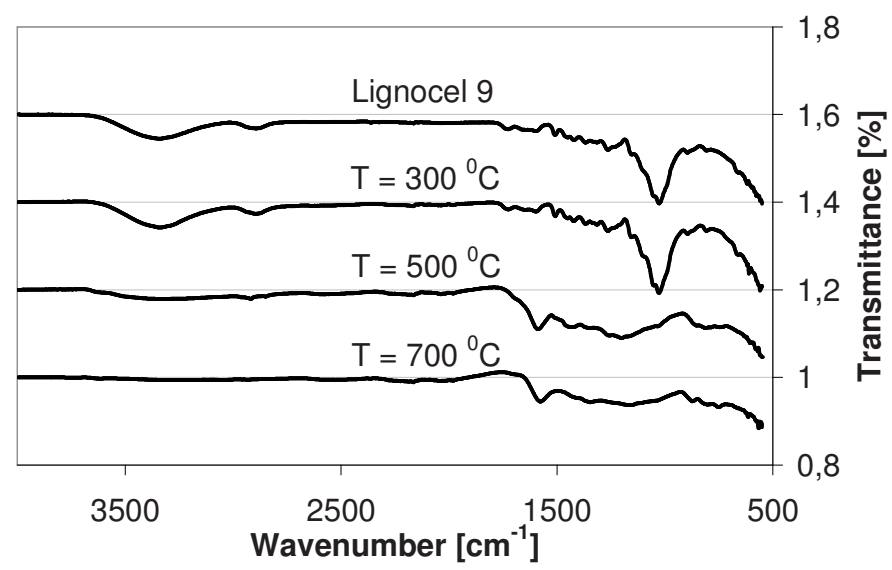

Figure 3.9 FTIR analyses "char" (holding time $1 \mathrm{~s}$, heating rate $=7000{ }^{\circ} \mathrm{C} / \mathrm{s}$ )

The molecular weight distribution of the oil and the THF- extractible char fraction produced at 300, 500 and $700{ }^{\circ} \mathrm{C}$ is shown in Figure $3.4 \mathrm{E}$ and $\mathrm{F}$ respectively. First it should be noticed that the differences between the molecular weight distributions of the oils were small. The difference between the M-curves of 300 and $500{ }^{\circ} \mathrm{C}$ is likely to be explained by the increased lignin conversion at $500{ }^{0} \mathrm{C}$. The NMR data (Table 3.4) indicate that hardly any aromatic compounds - likely to be originating from lignin (section 3.4.1) - were found for the oil produced at $300{ }^{\circ} \mathrm{C}$. In contrast to conventional pyrolysis set-ups, the average molecular weight of the oil in our wire-mesh reactor increased slightly with temperature from 500 to $700{ }^{0} \mathrm{C}$. Based on the mechanism postulated in Figure 3.1 larger molecules are expected to escape from the "decomposing biomass" by vaporization/sublimation at higher temperatures ${ }^{57}$. The rate of scission reactions that would lower the molecular weight of the oil is also expected to rise with temperature (evidenced by higher gas yield). These two opposing phenomena can explain the slight increase of the average molecular weight of the oil with temperature as observed in the wire mesh reactor. This is supported by the $\mathrm{M}_{\mathrm{w}}$-distribution of the compounds that were extracted from the char with THF. This extract may be considered as precursors to either oil (which has not yet escaped from the "decomposing biomass") or char. It should be noted that the amount of this THF-extractible char could not be quantified. Higher THF extractible molecular weight components were left behind in the char at lower temperatures, suggesting they could not evaporate/sublimate at these temperatures yet (Figure 3.4B).

After pyrolysis, SEM photos of the 'char' produced at $300{ }^{0} \mathrm{C}$ showed that the fibrous wood structure was still present (Figure 3.10). The fibrous structure had completely disappeared at $670{ }^{\circ} \mathrm{C}$. 
It seems that part of the Lignocel 9 has passed through some sort of liquid stage as also observed by other researchers ${ }^{26-31}$.

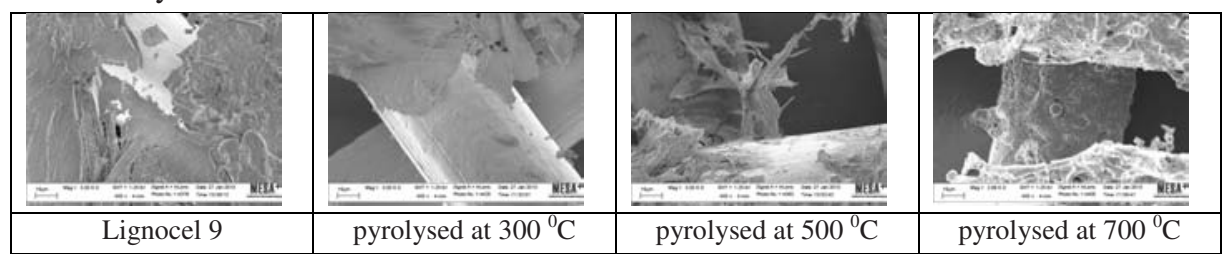

Figure 3.10 SEM photos of mesh and "char", magnification 3000 times (holding time $1 \mathrm{~s}$, heating rate = $7000^{0} \mathrm{C} / \mathrm{s}$ )

\subsubsection{Lignocel $9+6.5 \cdot 10^{3} \mathrm{ppm} \mathrm{K}$}

The presence of potassium is known to have a strong effect on the pyrolysis process ${ }^{\text {(chapter }}$ 4)5,64-66. In a wire-mesh reactor, also an influence of $\mathrm{K}$ was observed during the pyrolysis of beech wood by Nik-Azar et al ${ }^{66}$. Their char yield decreased from 17-18 wt $\%$ to $6 \mathrm{wt} \%$ when reducing the amount of $\mathrm{K}$ in the feedstock from $1.25 \cdot 10^{4} \mathrm{ppm}$ to $2.0 \cdot 10^{1} \mathrm{ppm}$. We carried out some tests in our wire-mesh reactor to study the influence potassium chloride (potassium $6.4 \cdot 10^{3} \mathrm{ppm}$ ) in the relative absence of vapor phase reactions on the char yield (Table 3.5).

The char yield for the potassium impregnated Lignocel 9 (10 wt $\%$ char) was twice as large as the one obtained using untreated Lignocel 9 (5 wt $\%$ char). High char (30 wt $\%$ ) yields were also obtained during the pyrolysis of xylan containing $8.5 \mathrm{wt} \%$ ash (section 3.4.1). In a previous study of our group, the large effect of $\mathrm{K}$ on heterogeneous vapor phase reactions was shown: for Lignocel 9 the char yield increased from 16 till $42 \mathrm{wt} \%$ when minerals were present inside the fluidized bed reactor ${ }^{\text {(chapter } 4) 5}$. The catalytic effect of potassium on cross-linking reactions inside the "decomposing biomass" could not be established in that study. This study indicates that not only interactions between $\mathrm{K}$ and vapors can lead to extra char formation, but $\mathrm{K}$ can also directly catalyze (cross)-linking reactions inside the "decomposing biomass", although the resulting (extra and total) char yield is relatively low.

\subsection{Conclusions}

This study provides understanding of the very complex pyrolysis mechanism. Decomposition reactions in (almost) absence of vapor phase reactions of pine wood and model compounds were studied in a previously developed wire-mesh reactor. The experiments have been carried out under extreme conditions. In a standard experiment, the wire-mesh reactor was operated at a set-temperature of $500{ }^{\circ} \mathrm{C}$, heating rate of $\sim 7000$ ${ }^{0} \mathrm{C} / \mathrm{s}$ under vacuum and using liquid nitrogen cooling to ensure a short vapor residence time $(<15-25 \mathrm{~ms})$. Levoglucosan and glucose were vaporized /sublimated and recovered 
as products without the occurrence of chemical reactions showing that the decomposition reactions inside the particles and vapor phase reactions were efficiently suppressed.

High oil and low char and gas yields were obtained during the pyrolysis of pine wood, cellulose and lignin compared to "conventional" pyrolysis processes. The maximum oil yield for pine wood was achieved around $500{ }^{0} \mathrm{C}(84 \mathrm{wt} \%)$. However, the oil yield at 700 ${ }^{0} \mathrm{C}$ was still high: $60 \mathrm{wt} \%$. Even for lignin, an oil yield of $78 \mathrm{wt} \%$ was obtained, while yields around $55 \mathrm{wt} \%$ are generally reported in literature. Cellulose was completely volatilized in our wire-mesh reactor resulting in $95 \mathrm{wt} \%$ oil and $4 \mathrm{wt} \%$ CO. Besides levoglucosan, also larger sugars could escape from the "decomposing cellulose" due to the fast removal of (heavy) volatiles under the conditions in our wire-mesh reactor. From these observations we conclude that (cross)-linking reactions did not proceed during the decomposition of cellulose. Minerals were shown to directly catalyze (cross)-linking reactions inside the solid/liquid decomposing biomass particles; the char yield for the potassium impregnated pinewood (10 wt $\%$ char) was twice as large as the one obtained using untreated wood (5 wt $\%$ char).

A heating rate of $50{ }^{\circ} \mathrm{C} / \mathrm{s}$ corresponds approximately with the average heating rate of a 2 $\mathrm{mm}$ particle from 20 till $490{ }^{\circ} \mathrm{C}$ inside a fluidized bed reactor operated at $500{ }^{0} \mathrm{C}$. When lowering the heating rate of the wire-mesh reactor from the standard $\sim 7000{ }^{0} \mathrm{C} / \mathrm{s}$ to 50 ${ }^{0} \mathrm{C} / \mathrm{s}$, a decline in oil yield and an increase in gas (especially $\mathrm{CO}_{2}$ ) and char yield were observed for all feedstocks. In addition, the average molecular weight decreased when lowering the heating rate. The largest effect was observed during the pyrolysis of lignin. These data show that not only the (almost) absence of vapor phase reactions in our wiremesh reactor is responsible for the high oil yields, but also the extreme heating rate is playing an important role.

Our data were interpreted successfully with a physical-chemical mechanism (Figure 3.1). The basic idea behind this mechanism is that the amount and composition of the solid/liquid "decomposing biomass" is changing in time due to competition between (cross)-linking reactions, scission reactions and mass transfer of decay fragments out of the decomposing particle. The extent of (cross)-linking reactions is dependent of the used feedstock, increases at lower temperatures (and thus heating rates), in the presence of $\mathrm{K}$ and at longer residence time of decay fragments in the decomposing biomass particles. We observed high oil yields in our wire-mesh reactor because of i) the fast removal of volatiles from the decomposing particles and ii) the high heating rates. 


\section{References}

1. D. Mohan, C.U. Pittman, P.H. Steele, Pyrolysis of wood/biomass for bio-oil: a critical review, Energy and Fuels, 20, 848-889, 2006

2. A.V. Bridgwater, Review of fast pyrolysis of biomass and product upgrading, Biomass and Bioenergy, 2011, article in press

3. S.R.A. Kersten, X. Wang, W. Prins, W.P.M. van Swaaij, Biomass pyrolysis in a fluidized bed reactor. Part 1: literature review and model simulations, Ind. Eng. Chem. Res. 44, 8773-8785, 2005

4. K. Sipilä, E. Kuoppala, L. Fagernäs, A. Oasmaa, Characterization of biomass-based flash pyrolysis oils, Biomass and Bioenergy, 14 (2), 103-113, 1998

5. E. Hoekstra, R.J.M. Westerhof, W. Windt, W. Brilman, W.P.M. van Swaaij, S.R.A. Kersten, J.A. Hogendoorn, Heterogeneous and homogeneous reactions of pyrolysis vapors from pine wood, AIChE-Journal, accepted for publication (chapter 4 of this thesis)

6. E. Hoekstra, W.P.M. Van Swaaij, S. R.A. Kersten, J.A. Hogendoorn, Fast pyrolysis in a novel wire-mesh reactor: initial decomposition products of pine wood, send for publication (chapter 2 this thesis)

7. F.J. Kilzer, A. Broido, Speculations on the nature of cellulose pyrolysis, Pyrodynamics, 2, 151163,1965

8. A. Broido, M. Weinstein, Low temperature isothermal pyrolysis of cellulose, Thermal analysis vol 3. - proceedings third ICTA DAVOS, 1971

9 A.G.W. Bradburry, Y. Sakai, F. Shafizadeh, A kinetic model for pyrolysis of cellulose, J. Appl. Polym. Sci, 23, 3271-3280, 1979

10. F. Shafizadeh, Review introduction to pyrolysis of biomass, J. Anal. Appl. Pyrolysis, 3, 283-305, 1982

11. C.A. Koufopanos, G. Maschio, A. Lucchesi, Kinetic modeling of the pyrolysis of biomass and biomass components, Can. J. Chem. Eng., 67, 75-84, 1989

12. F. Thurner, U. Mann, Kinetic investigation of wood pyrolysis, Ind. Eng. Chem. Process. Des., 20, 482-488, 1981

13. F. Shafizadeh, P.S. Chin, Thermal deterioration of wood, Chapter 5 in Wood Technology Chemical Aspects, 57-81, ACS Symposium Series, 43, 1977

14. S. Wang, X. Guo, K. Wang, Z. Luo, Influence of the interaction of components on the pyrolysis behavior of biomass, J. Anal. Appl. Pyrolysis, 91, 183-189, 2011

15. T. Hosoya, H. Kawamoto, S. Saka, Cellulose-hemicellulose and cellulose-lignin interactions in wood pyrolysis at gasification temperature, J. Anal. Appl. Pyrolysis, 80, 118-125, 2007

16. Q. Lu, Z. Zhong, S. Wang, Z. Luo, Interactions of biomass components during pyrolysis a TGFTIR study, J. Anal. Appl. Pyrolysis, 90, 213-218, 2011

17. P. de Wild, Biomass pyrolysis for chemical, PHD-thesis, University of Groningen, 2011

18. C. Di Blasi, Comparison of semi-global mechanisms for primary pyrolysis of lignocellulosic fuels, J. Anal. Appl. Pyrolysis, 47, 43-64, 1998

19. F. Shafizadeh, Pyrolysis and combustion of cellulosic materials, Adv. Carbohydr. Chem., 23, 419474, 1968

20. J.P. Diebold, A unified, global model for the pyrolysis of cellulose, Biomass and Bioenergy, 7, 7585,1994

21. G. Varhegyi, E. Jakab, Is the Broido-Shafizadeh model for cellulose pyrolysis true?, Energy and Fuels, 8, 1345-1352, 1994

22. M.J. Antal, G. Varhegyi, Cellulose pyrolysis kinetics the current state of knowledge, Ind. Eng. Chem. Res., 34, 703-717, 1995

23. D.K. Shen, S. Gu, K.H. Luo, S.R. Wang, M.X. Fank, The pyrolytic degradation of wood-derived lignin from pulping process, Bioresour. Technol., 101, 6136-6146, 2010

24. W. Chaiwat, I. Hasegawa, T. Tani, K. Sunagawa, K. Mae, Analysis of cross-linking behavior during pyrolysis of cellulose for elucidating reactions pathway, Energy and Fuels, 23, 5765-5772, 2009

25. D. Radlein, The production of chemicals from fast pyrolysis bio-oils in fast pyrolysis of biomass: a handbook, volume 2, edited by A.V. Bridgwater, 2002 


\section{Chapter 3}

26. E.M. Suuberg, P.E. Unger, W.D. Lilly, Experimental study on mass transfer from pyrolysing coal particles, Fuel, 64, 956-962, 1985

27. V. Mamleev, S. Bourbigot, M. Le Bras, J. Yvon, The facts and hypotheses relating to the phenomenological model of cellulose pyrolysis. Interdependence of steps. J. Anal. Appl. Pyrolysis, 84, 1-17, 2009

28. O. Boutin, M. Ferrer, J. Lede, Radiant flash pyrolysis of cellulose - evidence for the formation of short life time intermediate liquid species, J. Anal. Appl. Pyrolysis, 47, 13-3, 1998

29. T. Fisher, M. Hajaligol, B. Waymack, D. Kellogg, Pyrolysis behaviour and kinetics of biomass derived materials, J. Anal. Appl. Pyrolysis, 62(2), 331-349, 2002

30. D.J. Nowakowski, A.V. Bridgwater, D.C. Elliott, D. Meier, P. de Wild, Lignin fast pyrolysis: results from an international collaboration, J. Anal. Appl. Pyrolysis, 88, 53-72, 2010

31. T.J. Haas, M.R. Nimlos, B.S. Donohoe, Real-time and post-reaction microscopic structural analysis of biomass undergoing pyrolysis, Energy and Fuels, 23, 3810-3817, 2009

32. R.W.J. Westerhout, R.H.P. Balk, R. Meijer, J.A.M. Kuipers, W.P.M. van Swaaij, Examination and evaluation of the use of screen heaters for the measurement of the high temperature pyrolysis kinetics of polyethene and polypropene, Ind. Eng. Chem. Res., 36, 3360-3368, 1997

33. F.R. Russell, H.C. Hottel, Rate of ethylene polymerization, Ind. Eng. Chem., 30(2), 183-189, 1938

34. E. Hoekstra, S.R.A. Kersten, A. Tudos, D. Meier, J.A. Hogendoorn, Possibilities and pitfalls in analyzing (upgraded) pyrolysis oil by size exclusion chromatography (SEC), J. Anal. Appl. Pyrolysis, 91, 76-88, 2011

35. L. Ingram, D. Mohan, M. Bricka, P. Steele, D. Strobel, D. Crocker, B. Mitchell, J. Mohammad, K. Cantrell, C.U. Pittman, Pyrolysis of wood and bark in an auger reactor: physical properties and chemical analysis of the produced bio-oils, Energy and Fuels, 22(1), 614-625, 2008

36. P.R. Patwardhan, R.C. Brown, B.H. Shanks, Product distribution from the fast pyrolysis of hemicellulose, ChemSusChem, 4, 636-643, 2011

37. M.R. Hajaligol, J.B Howard, J.P. Longwell, W.A. Peters, Product compositions and kinetics for rapid pyrolysis of cellulose, Ind. Eng. Chem. Process Des. Dev., 21, 457-465, 1982

38. M.R. Hajaligol, J.B. Howard, W.A. Peters, An experimental and modeling study of pressure effects on tar release by rapid pyrolysis of cellulose sheets in a screen heater, Combustion and Flame, 95, 47-60, 1993

39. D.K. Shen, S. Gu, The mechanism for thermal decomposition of cellulose and its main products, Bioresour. Technol, 100, 6496-6504, 2009

40. P.R. Patwardhan, J.A. Satrio, R.C. Brown, B.H Shanks, Product distribution from fast pyrolysis of glucose-based carbohydrates. J. Anal. Appl. Pyrolysis; 86, 323-330, 2009

41. H. Kawamoto, M. Murayama, S. Saka. Pyrolysis behavior of levoglucosan as an intermediate in cellulose pyrolysis: polymerization into polysaccharide as a key reaction to carbonized product formation. J. Wood. Science; 49, 469-473, 2003

42. T.R. Nunn, J.B. Howard, J.P. Longwell, W.A. Peters, Product compositions and kinetics in the rapid pyrolysis of milled wood lignin, Ind. Eng. Chem. Process Des. Dev., 24, 844-852, 1985

43. V.Oja, E.M. Suuberg, Vapor pressure and enthalpies of sublimation of D-glucose, D-xylose, cellobiose, and levoglucosan, J. Chem. Eng. Data, 44, 26-29, 1999

44. C. Di Blasi, C. Branca, Kinetics of primary product formation from wood pyrolysis, Ind. Eng. Chem. Res. 40 (23), 5547-5556, 2001

45. F. Shafizadeh, R.H. Furneaux, T.G. Cochran, J.P. Scholl, Y. Sakai, Production of levoglucosan and glucose from pyrolysis of cellulosic materials, J. Appl. Polym. Sci., 23(12), 3525-3539, 1979

46. J. Lian, S. Chen, S. Zhou, Z. Wang, J. O'Fallon, C.Z. Li, M. Garcia-Perez, Separation, hydrolysis and fermentation of pyrolytic sugars to produce ethanol and lipids, biosource technology, 101, 9688-9699, 2010

47. O. Onay, S.H. Beis, O.M. Kockar, Fast pyrolysis of rape seed in a well-swept fixed-bed reactor, J Anal. Appl. Pyrolysis, 58-59, 995-1007, 2001

48. M.G. Gronli, M.C. Melaaen, Mathematical model for wood pyrolysis - comparison of experimental measurements with model predictions, Energy and fuels, 14(4), 791-800, 2000

49. P.T. Williams, S. Besler, The influence of temperature and heating rate on the slow pyrolysis of biomass, renewable energy, 7(3), 233-250, 1996

50. M. Nik-Azar, M.R. Hajaligol, M. Sohrabi, B. Dabir, Effects of heating rate and particle size on the product yields from rapid pyrolysis of beech wood, Fuel Sci Technol. Int., 14, 479-502, 1996 
51. A.R. Fraga, A.F. Gaines, R. Kandiyoti, Characterization of biomass pyrolysis tars produced in the relative absence of extraparticle secondary reactions, Fuel, 70, 803-809, 1991

52. G.V.C. Peacocke, E.S. Madrali, C.Z. Li, A.J. Guell, F. Wu, R. Kandiyoti, A.V. Bridgwater, Effect of reactor configuration on the yields and structures of pine-wood derived pyrolysis liquids: a comparison between ablative and wire-mesh pyrolysis, Biomass and Bioenergy, 7, 155-167, 1994

53. A.R.F. Drummond, I.W. Drummond, Pyrolysis of sugar cane bagasse in a wire-mesh reactor, Ind. Eng. Chem. Res., 35, 1263-1268, 1996

54. J. Shen, X.S. Wang, M. Garcia-Perez, D. Mourant, M.J. Rhodes, C.Z. Li, Effects of particle size on the fast pyrolysis of oil mallee woody biomass, Fuel, 88, 1810-1817, 2009

55. R.J.M. Westerhof, D.W.F. Brilman, M. Garcia-Perez, Z. Whang, S.R.G. Oudenhoven, W.P.M. van Swaaij, S.R.A. Kersten, Step-wise pyrolysis of pine wood, to be published

56. F. de Miguel Mercader, M.J. Groeneveld, S.R.A. Kersten, R.H. Venderbosch, J.A. Hogendoorn, Pyrolysis oil upgrading by high pressure thermal treatment, Fuel 89(10), 2829-2837, 2010

57. Handbook of chemistry and physics, $84^{\text {th }}$ edition, 2003-2004, CRC Press, David R. Lide

58. R.J.M. Westerhof, D.W.F. Brilman, W.P.M. van Swaaij, S.R.A. Kersten, Effect of temperature in fluidized bed fast pyrolysis of biomass: oil quality assessment in test units, Ind. Eng. Chem. Res., 49 (3), $1160-1168,2010$

59. M. Garcia-Perez, X.S. Wang, J. Shen, M.J. Rhodes, F. Tian, W.J. Lee, H. Wu, C.Z. Li, Fast pyrolysis of oil malle woody biomass: effect of temperature on the yield and quality of pyrolysis products, Ind. Eng. Chem. Res.,47(6), 1846-1854, 2008

60. T.R. Nunn, J.B. Howard, J.P. Longwell, W.A. Peters, Product composition and kinetics in the rapid pyrolysis of sweet gum hardwood, Ind. Eng. Chem. Process Des. Dev., 24, 836-844, 1985

61. J.F. Stubington, S. Aiman, Pyrolysis kinetics of bagasse at high heating rates, Energy and Fuels, 8, 194-203, 1994

62. A.A. Zabaniotou, D. Gogotsis, A.J. Karabelas, Product composition and kinetics of flash pyrolysis of Erica Arborea (biomass), J. Anal. Appl. Pyrolysis, 29, 73-87, 1994

63. T. Okuno, N. Sonoyama, J.I. Hayashi, C.Z. Li, C. Sathe, T. Chiba, Primary release of alkali and alkaline earth metallic species during the pyrolysis of pulverized biomass, Energy and fuels, 19, 2164-2171, 2005

64. R.H. Venderbosch W., Prins, Fast pyrolysis technology development, Biofuels. Bioprod. Biorefin., 4, 178-208, 2010

65. A. Jensen, K.D. Johansen, TG-FTIR Study of the influence of potassium chloride on wheat straw pyrolysis. Energy and Fuels; 12, 929-938, 1998

66. M. Nik-Azar, M.R. Hajaligol, M. Sohrabi, B. Dabir, Mineral matter effects in rapid pyrolysis of beech wood, Fuel Process. Technol., 51, 7-17, 1997 
Chapter 4

\section{Heterogeneous and homogeneous}

\section{reactions of pyrolysis vapors from}

\section{pine wood}

To maximize oil yields in the fast pyrolysis of biomass it is generally accepted that vapors need to be rapidly quenched. In this study, the influence of the heterogeneous and homogeneous vapor phase reactions on yields and oil composition were studied using a fluidized bed reactor. Even high concentrations of mineral low char (till 55 vol\%) appeared not to be catalytically active. However, the presence of minerals, either in biomass or added, does influence the yields, especially by the occurrence of vapor phase charring/polymerization reactions. Contradictory, in the absence of minerals, homogeneous vapor phase cracking reactions were dominant over polymerization/charring reactions $\left(400-550{ }^{\circ} \mathrm{C}, 1-15 \mathrm{~s}\right)$. With increasing vapor residence time, the oil yield reached an asymptotic value, which decreased with temperature. At a vapor temperature of $400{ }^{\circ} \mathrm{C}$ no decrease in oil yield was observed, but dedicated analysis showed that homogeneous vapor to vapor reactions had occurred. 


\subsection{Introduction}

Fast pyrolysis is the thermochemical decomposition of organic material (moisture content typically $<10 \mathrm{wt} \%$ ) at $400-600{ }^{0} \mathrm{C}$ in the absence of oxygen ${ }^{1-3}$. In this process, biomass is converted into char (typically 15-25 wt\%), permanent gases (typically 10-20 wt\%) and pyrolysis oil (typically 60-70 $\mathrm{wt} \%)^{1-3}$. Besides direct use for combustion ${ }^{3}$ and flavor production $^{4}$ pyrolysis oil is considered to be an intermediate to be used in subsequent processes ${ }^{4}$. For example, pyrolysis oil could be i) upgraded so the resulting oil can be corefined in a standard refinery unit to (blending compounds for) fuels ${ }^{3}$ ii) gasified to syngas followed by Fischer Tropsch synthesis to fuels/waxes or methanol synthesis ${ }^{2,4}$ and iii) used as source for the extraction of chemicals (glycolaldehyde, levoglucosan, phenolics $)^{3,4}$. The potential of fast pyrolysis as biomass pre-treatment step is directly related to the significantly higher density of the oil $\left(\sim 1200 \mathrm{~kg} / \mathrm{m}^{3}\right)$ compared to the original biomass $\left(\sim 150 \mathrm{~kg} / \mathrm{m}^{3}\right)$ and the resulting transportations benefits ${ }^{2,4}$.

Pyrolysis oil is a mixture of water and hundreds of (oxygenated) organic compounds ${ }^{1}$. Over the past three decades, extensive research on the development of fast pyrolysis processes has been carried out. In order to obtain high oil yields it is generally accepted that 1) high heating rates are required 2) the pyrolysis reaction temperature needs to be controlled around $500{ }^{\circ} \mathrm{C}$ and 3 ) pyrolysis vapors/aerosols need to be rapidly quenched ( $<2 s)^{1-6}$. In the last decade increased fundamental insight in pyrolysis has been obtained ${ }^{7-}$ 12 with also quite some experimentally observed exceptions to the aforementioned general 'design rules ${ }^{9,10,12}$ For example, Scott et al. ${ }^{12}$ found no significant influence of the vapor's residence time on oil yields at up to $10 \mathrm{~s}$ and temperatures between 400 and 450 ${ }^{0} \mathrm{C}$. A critical assessment of the 'design rules', their theoretical background and experimental verification seems therefore appropriate.

Pyrolysis products are formed by decomposition reactions of the biomass matrix (cellulose, hemicellulose and lignin) followed by reactions of produced gases, vapors, aerosols, liquids and solids. The vapors and aerosols form, after condensation, the liquid product called 'pyrolysis oil' or 'bio-oil'. In our experiments, it is not known what the nature of the oil is at the pyrolysis temperature, viz. vapors, aerosols or a combination of those. In the remainder of the text, both vapors and aerosols are denoted as vapors, but the reader should realize that "vapors" represent any combination of vapors and aerosols. Reactions of vapors are known to reduce the oil yield ${ }^{13-20}$ by both homogeneous and heterogeneous reaction pathways. However, there is only limited information on the effect of these reactions on the oil composition ${ }^{14,20}$. Heterogeneous reactions can proceed when produced vapors leave the reacting biomass particle, vapors encounter other particles (char, ash, catalysts) or when vapors are in contact with the (hot) reactor material. The extent of vapor reactions is reported to depend, amongst others, on the 
temperature of the vapor phase, on the nature of the solid surfaces and the exposure time to high temperatures and/or surfaces, ${ }^{13-20}$ but possibly on the concentration of the vapors as well ${ }^{14,21}$. Some researchers reported a significant influence of the presence of char on the extent of heterogeneous vapor phase reactions, ${ }^{13,22}$ while others did not observe such an influence ${ }^{9}$. The controversies in these results are probably related to i) char composition, and ii) difficulties in separating the individual effects of biomass decomposition and homogeneous and heterogeneous vapor phase reactions while interpreting the results.

The objective of this chapter is to obtain more unequivocal insight on the influence of a). the vapor phase residence time and temperature and b) char and minerals, on the oil yield and composition. In the last part of this paper, the results are discussed in relation to kinetic model development and the engineering aspects of pyrolysis units.

\subsection{Equipment and procedure}

\subsubsection{Feedstock materials}

The feedstock materials used and their properties are summarized in Table 4.1. Pine wood with a low mineral content (Lignocel 9, purchased from Rettenmaier \& Sohne $\mathrm{GmbH}$, Germany) was used for the majority of the experiments. Some experiments were carried out with feedstocks high in mineral content. The presence of potassium is known to have a strong effect on the pyrolysis process ${ }^{2,28,29}$. For this reason we have chosen to impregnate pine wood with $\mathrm{KCl}$ (Sigma, P9333, purity $>99.0 \%$ ) by mixing pine wood rigorously with a $\mathrm{KCl}$ solution and subsequently evaporating the water. Straw (purchased from DIVRO) was used as biomass which, by nature, has a high mineral and especially potassium content.

Table 4.1 Biomass properties

\begin{tabular}{|l|l|l|l|}
\hline & Pine Wood & Pine Wood + KCl & Straw \\
\hline ash $\left[\mathrm{wt} \%_{\text {dry }}\right]$ & 0.6 & 1.34 & 6.0 \\
\hline $\mathrm{C}\left[\mathrm{wt} \%_{\text {daf }}\right]$ & 47.9 & 47.9 & 49.8 \\
\hline $\mathrm{H}\left[\mathrm{wt} \%_{\text {daf }}\right]$ & 5.9 & 5.9 & 6.0 \\
\hline $\mathrm{O}\left[\mathrm{wt} \%_{\text {daf }}\right]$ & 46.2 & 46.2 & 44.2 \\
\hline Water $[\mathrm{wt} \%]$ & $2-10$ & 0.7 & 0.4 \\
\hline $\mathrm{K}\left[\mathrm{ppm}{ }_{\text {dry }}\right]$ & $4.0 \mathrm{E}+02$ & $6.5 \mathrm{E}+03$ & $1,2 \mathrm{E}+04$ \\
\hline Na $[\mathrm{ppm}$ dry $]$ & $1.0 \mathrm{E}+02$ & $1.0 \mathrm{E}+02$ & $8.5 \mathrm{E}+1$ \\
\hline Particle size $[\mathrm{mm}]$ & $\sim 1$ & $\sim 1$ & length $<5 \mathrm{~mm}$ \\
\hline
\end{tabular}

\subsubsection{Pilot Plant: analysis of in-bed char and minerals}

A fluidized sand bed fast pyrolysis unit was used to study the effect of char and mineral hold-up in the bed. The reported char and mineral hold-ups (vol\% and wt $\%$ ) are expressed on total solid (char + sand + minerals) basis. The set-up consisted of a 
continuous feeding system $(0.5-0.9 \mathrm{~kg} / \mathrm{hr})$, a fluidized bed reactor $\left(<200 \mathrm{~d}_{\text {sand }}<300 \mu \mathrm{m}\right)$, three cyclones and a condensation train (spray column and intensive cooler) placed in series. The complete set-up including a comprehensive validation is described in detail elsewhere ${ }^{10,30}$. The standard deviations for the char, gas, oil and water yield were 1.0, 0.9, 1.3 and $1.0 \mathrm{wt} \%$ respectively showing that the reproducibility of the experiments is $\operatorname{good}^{30}$. Information about the operating conditions is listed in Table 4.2 and Table 4.3. This set-up will further be referred to as 'pilot plant'.

Table 4.2 Experimental specification for experiments in pilot plant $\left(\mathrm{T} \sim 450-490{ }^{\circ} \mathrm{C}\right)$

\begin{tabular}{|l|l|l|c|c|c|}
\hline \multirow{2}{*}{ Name } & \multirow{2}{*}{ Biomass } & \multirow{2}{*}{ Additives } & \multicolumn{2}{c|}{ Char Hold-Up [vol\%] } & K+ Na Hold-Up \\
\cline { 3 - 5 } & & & Pine & Straw & ${ }^{* *}$ \\
\hline $20 \mathrm{vol} \%$ char & pine & none & 20 & 0 & 0.005 \\
\hline $55 \mathrm{vol} \%$ char & pine & none & 55 & 0 & 0.021 \\
\hline $\mathrm{KCl}$ impregnated & $\mathrm{KCl}^{\mathrm{a}}$, pine & none & 50 & 0 & 0.176 \\
\hline straw & straw & none & 0 & 35 & 0.167 \\
\hline $\mathrm{Na} / \mathrm{K}$ additive $0.7 \mathrm{wt} \%$ & pine & $\mathrm{Na}_{2} \mathrm{CO}_{3}{ }^{\mathrm{b}}, \mathrm{K}_{2} \mathrm{CO}_{3}{ }^{\mathrm{c}}$ & 40 & 0 & 0.709 \\
\hline $\mathrm{Na} / \mathrm{K}$ additive $0.1 \mathrm{wt} \%$ & pine & $\mathrm{Na}_{2} \mathrm{CO}_{3}{ }^{b}, \mathrm{~K}_{2} \mathrm{CO}_{3}{ }^{\mathrm{c}}$ & 31 & 0 & 0.110 \\
\hline straw char additive & pine & straw char & 25 & 20 & 0,111 \\
\hline
\end{tabular}

*) Properties listed in Table $4.1 * *$ Mineral is minerals char plus minerals additives

a) Sigma-Aldrich, P9333, purity $>99.0 \%$ b) Sigma-Aldrich S7795, purity $>99.0 \%{ }^{c}$ ) Sigma-Aldrich $23653-412 \mathrm{~K}_{2} \mathrm{CO}_{3}$, purity $=99.0 \%$

Table 4.3 Operating conditions pilot plant and lab-scale fluidized bed reactor

\begin{tabular}{|c|c|c|c|}
\hline \multicolumn{2}{|c|}{ Properties } & Pilot Plant & $\mathrm{FB}+\mathrm{T}$-reactor \\
\hline General & Run Time [min] & $90-120$ & 60 \\
\hline \multirow{3}{*}{ Feeding } & $\Phi_{\mathrm{m}, \text { sand }}[\mathrm{kg} / \mathrm{hr}]$ & $1.6-4.1$ & No sand fed to reactor \\
\hline & $\Phi_{\mathrm{m}, \text { biomass }}[\mathrm{kg} / \mathrm{hr}]$ & $0.5-0.9$ & 0.15 \\
\hline & $\Phi_{\mathrm{v}, \mathrm{N} 2} / \Phi_{\mathrm{m}, \text { biomass }}[\mathrm{N} 1 / \mathrm{g}]$ & $\sim 2.5$ & $\sim 4.5$ \\
\hline \multirow{6}{*}{$\begin{array}{l}\text { Fluidized bed } \\
\text { reactor }\end{array}$} & Char Hold-Up [vol\%] & $20-55$ ( stationary) & $0-25$ (increasing) \\
\hline & $\mathrm{T}_{\text {reactor }}\left[{ }^{0} \mathrm{C}\right]$ & $400-530$ & 500 \\
\hline & $\tau_{\text {vapors }}[\mathrm{s}]$ & $1.6-1.9$ & $\sim 1.5$ \\
\hline & $\tau_{\text {particles }}[\mathrm{min}]$ & $20-40 \mathrm{~min}$ & No removal of particles \\
\hline & $\mathrm{U} / \mathrm{U}_{\mathrm{mf}}[-]$ & 4 & 3 \\
\hline & Char separation & three cyclones in series & $\begin{array}{c}9 \mu \mathrm{m} \text { and } 5 \mu \mathrm{m} \text { filters in } \\
\text { series }\end{array}$ \\
\hline \multirow{5}{*}{$\begin{array}{l}\text { Tubular } \\
\text { reactor }\end{array}$} & $\mathrm{T}_{\text {tube system }}\left[{ }^{0} \mathrm{C}\right]$ & \multirow{5}{*}{$\begin{array}{c}\text { no tubular reactor } \\
\text { incorporated }\end{array}$} & $400,500,550$ \\
\hline & $\mathrm{T}_{\text {tube system }}[\mathrm{s}]$ & & $1.1-15.3$ \\
\hline & Vapors + gases [vol\%] & & $\sim 9$ \\
\hline & $\operatorname{Re}[-]$ & & $\sim 275-385$ \\
\hline & Pé [-] & & $\sim 20-260$ \\
\hline \multirow{2}{*}{$\begin{array}{l}\text { Condensation } \\
\text { System }\end{array}$} & $\mathrm{T}_{\text {first condensor }}\left[{ }^{0} \mathrm{C}\right]$ & 20 (spray column) & $<24(\mathrm{ESP})$ \\
\hline & $\mathrm{T}_{\text {second condensor }}\left[{ }^{0} \mathrm{C}\right]$ & 0 & $<-8$ \\
\hline
\end{tabular}


In the pilot-plant it was possible to control the char and mineral hold-up during the course of an experiment. A schematic overview of the reactor including the char/mineral hold-up regulation system is shown in Figure 4.1. The fluidized bed reactor ( $D=10 \mathrm{~cm}, \mathrm{H}=40$ $\mathrm{cm}$ ) was equipped with an overflow to remove the sand/char/mixture mixture on top of the bed to keep the bed level constant $\left(\mathrm{V}_{\text {reactor }}=1.8 \mathrm{l}\right)$. Biomass and sand were fed by two separate feeding screws. Additives like minerals and char could be added to the sand flow. The amount of char and minerals inside the fluidized bed reactor was controlled by adapting the sand/additives composition and feeding rate and by the biomass type and feeding rate. It was assumed that all solids in the fluidized bed were ideally mixed. For the "20 vol\% char" experiment (estimated value, based on assumption ideal mixing), the char hold-up inside the fluidized bed reactor was experimentally determined after the experiment to validate the assumption. A value of 19 vol\% was obtained which shows good agreement. Cold flow experiments did show that it was possible to fluidize sand/char mixtures up to $63 \mathrm{vol} \%$ of char so no problems concerning the fluidization behavior/mixing were to be expected during our experiments (up to $55 \mathrm{vol} \%$ char).

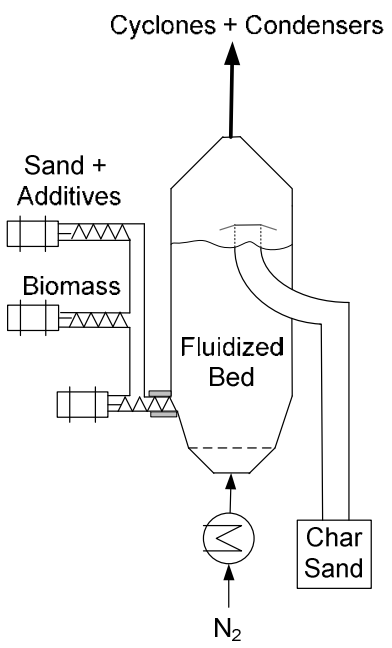

Figure 4.1 Char/mineral hold-up regulation system pilot plant

\subsubsection{Fluidized bed with tubular reactor placed in series (FB+T-Reactor): analysis of homogeneous vapor reactions}

Set-ups used in literature

In literature, a variety of set-ups is reported to have been used to study homogeneous pyrolysis vapor reactions. Although interesting results were obtained, many of the set-ups had some limitations making interpretation and extrapolation of results difficult. In several studies a batch type of pyrolysis reactor was coupled to a tubular reactor making continuous operation of the tubular reactor impossible ${ }^{13,14,16,17,31,32 .}$ In literature the vapor 
residence times was varied either by changing the carrier gas flow rate ${ }^{34-36}$ or by changing the reactor volume ${ }^{13,14,16-18,35,36}$. Variation of the residence time by variation of the carrier gas flow rate varies the concentration of the vapors, which could cause a change in the reaction pathways of the vapors and therewith yields and compositions ${ }^{14,21}$. Furthermore, in most set-ups the carrier gas flow rate and thus residence time can only be varied to a limited extent to prevent de-fluidization or excessive entrainment of solids. In some studies, the reactor volume was varied (and so vapor residence time) by changing the fast pyrolysis reactor volume ${ }^{21,36}$ or by placing a second reactor in series ${ }^{13,14,16,17}$. This last option makes it possible to decouple the fast pyrolysis - and vapor phase temperature and was therefore used in this study together with a continuous vapor source.

\section{Our set-up}

The fluidized bed reactor was identical to the one used in the pilot plant (section 4.2.2), however, in this set-up no feed and withdrawal of sand was applied to ease operation. A flow sheet of the set-up is given in Figure 4.2. The whole set-up including the fluidized bed reactor and tubular reactor will further be referred to as "FB+T-reactor" which is an abbreviation for "Fluidized Bed + Tubular"-reactor.

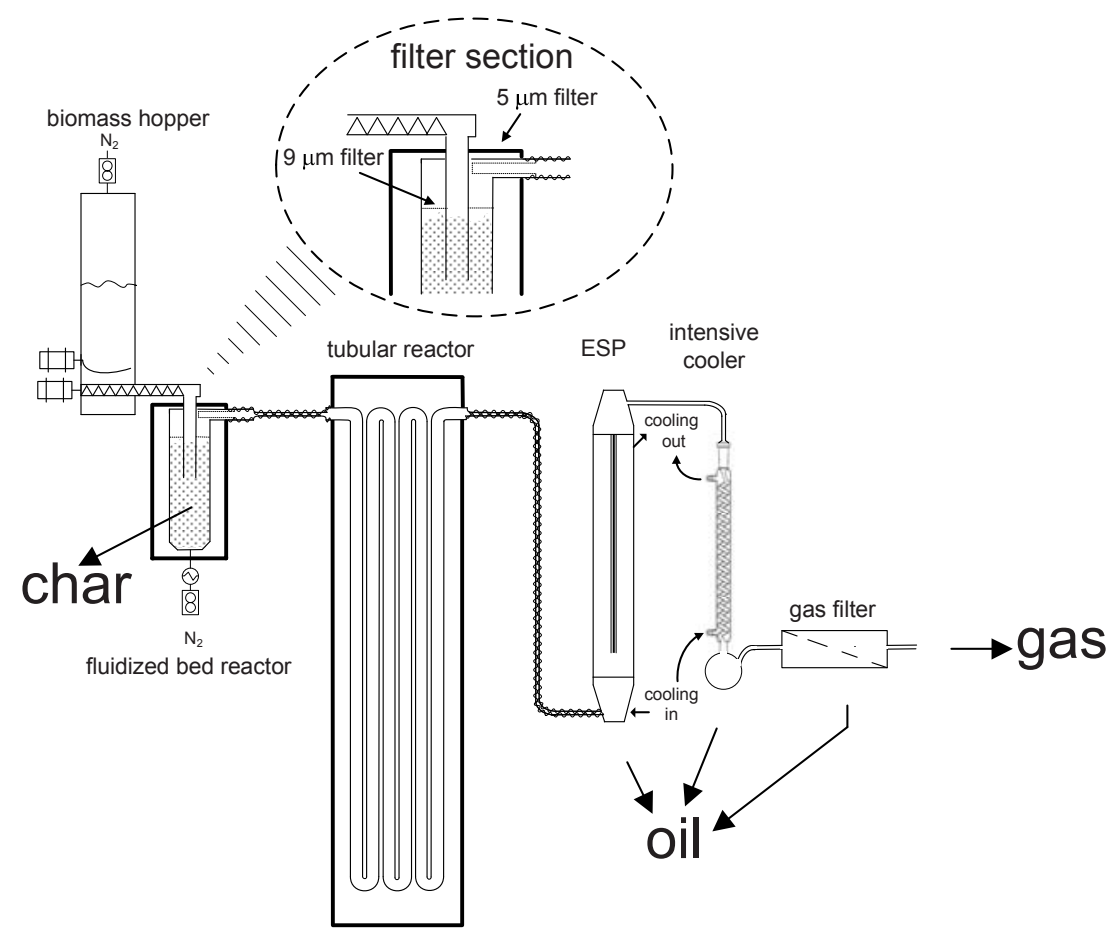

Figure 4.2 Fluidized bed and tubular reactor placed in series (FB+T-Reactor) 
Lignocel 9 was fed via a screw into the fluidized sand bed (at a height of $\sim 80 \%$ of the total bed height). The fluidized bed reactor was always operated at $500{ }^{0} \mathrm{C}$. The operating conditions of the standard run are summarized in Table 4.3. Preheated nitrogen gas $\left(3 \cdot \mathrm{U}_{\mathrm{mf}}\right)$ was fed through a sintered plate. Because this set-up was not operated continuously with respect to the solids phase, char built up in the course of an experiment (up to $25 \mathrm{vol} \%$ in 60 minutes). A custom made wire-mesh filter section (material purchased from Dinxperlo, Wire Weaving) $)^{\text {(chapter 5)8 }}$ was used to remove char from the gas/vapor stream. A schematic representation of this filter section is shown in the upper side in Figure 4.2. The first filter had a pore size of $9 \mu \mathrm{m}$ and was placed just above the fluidized bed. A second filter with a pore size of $5 \mu \mathrm{m}$, length of $8.5 \mathrm{~cm}$ and diameter of $2.2 \mathrm{~cm}$ was placed at the fluidized bed reactor exit (just before tubular reactor inlet). The solids content of the pyrolysis oil obtained without the use of the tubular reactor was always below the detection limit $(<0.002 \mathrm{wt} \%)$ indicating that a virtually solids-free gas/vapor stream was generated by using the filters. The temperature of the vapors leaving the fluid bed was controlled by heat tracing wrapped around the pipe (ID: 0.75 $\mathrm{cm}$ ) connecting the fluidized bed and tubular reactor. The average deviation of the entrance tubular reactor temperature from the set-point of the tubular reactor $(400,500$ or $550{ }^{0} \mathrm{C}$ ) was $6{ }^{0} \mathrm{C}$. The residence time of the pyrolysis vapors inside the fluidized bed reactor itself was approximately $1.5 \mathrm{~s}$.

In the tubular reactor system (placed after the pyrolysis unit) four different tubular reactors constructed of AISI 316 steel with lengths of 1, 2.5, 8 and $11 \mathrm{~m}$ and an inner diameter of $3 \mathrm{~cm}$ were used. The additional vapor phase residence time in these tubular reactors varied from 1 till $15 \mathrm{~s}$ and its temperature was maintained at 400,500 or $550{ }^{\circ} \mathrm{C}$. The temperature of the tubular reactor was regulated within $3{ }^{\circ} \mathrm{C}$ by an electrical oven in which four heating zones could be controlled independently. The Reynolds number of the gaseous stream was in the range of $275\left(550{ }^{\circ} \mathrm{C}\right)-385\left(400{ }^{\circ} \mathrm{C}\right)$ indicating that the flow was laminar. The Péclet number as calculated from $<\mathrm{v}>\mathrm{L} / \mathrm{D}_{\mathrm{ax}}$ varied from about 20 (400 $\left.{ }^{0} \mathrm{C}, 1 \mathrm{~m}\right)$ till $260\left(550{ }^{0} \mathrm{C} / 11 \mathrm{~m}\right)$, indicating near plug flow behaviour.

The vapor stream leaving the tubular reactor was condensed in a custom made jacketed electrostatic precipitator (ESP tube ID: $6.2 \mathrm{~cm} / \mathrm{L}: 44 \mathrm{~cm}$ ) operated at 17-21 kV. The temperature of the outgoing stream of this condenser was kept below $24{ }^{0} \mathrm{C}$ by pumping tap water through the annular space of the ESP. To the best of our knowledge, we are the first who are using a cooled ESP as main condenser directly after the reactor. Hereafter, the remaining uncondensed gas/vapor stream was sent to an intensive cooler $\left(\mathrm{T}<-8{ }^{0} \mathrm{C}\right)$ and a gas filter placed in series. About $97 \mathrm{wt} \%$ of the condensed organics was captured in the ESP, $2.7 \mathrm{wt} \%$ in the intensive cooler and $0.3 \mathrm{wt} \%$ in the gas filter. The oil was stored in a freezer at $-20{ }^{0} \mathrm{C}$ to prevent aging reactions ${ }^{37}$. 


\subsubsection{Product collection and analysis}

\section{Biomass}

The elemental composition (Fisons Instruments 1108 CHNS-O), ash content (NPRCEN/TS $15403-550{ }^{\circ} \mathrm{C}$ ), water content (drying in an oven at $105{ }^{\circ} \mathrm{C}$ for 24 hours ${ }^{30}$ ) and alkali/alkaline content (measured at vTI, Germany using ICP-OES) of the biomass feeds are reported in Table 4.1. The amount of dry ash free (daf) biomass fed during a run was determined by adjusting the mass difference of the biomass hopper before and after an experiment for the water and ash content of the feed.

\section{$\underline{\text { Gases }}$}

The procedure to determine the gas yield in the pilot plant reactor (section 4.2.2) is described in detail in an earlier publication ${ }^{30}$. In the FB+T-Reactor the nitrogen flow rate was set by a calibrated mass flow controller (Brooks). Gas samples were taken every 10 minutes. These samples were analysed in a gas chromatograph for $\mathrm{H}_{2}, \mathrm{CH}_{4}, \mathrm{CO}, \mathrm{CO}_{2}$, $\mathrm{C}_{2} \mathrm{H}_{4}, \mathrm{C}_{2} \mathrm{H}_{6}, \mathrm{C}_{3} \mathrm{H}_{6}, \mathrm{C}_{3} \mathrm{H}_{8}$ (Varian Micro GC CP-4900 with two analytical columns, $10 \mathrm{~m}$ Molsieve 5A and $10 \mathrm{~m}$ PPQ, using Helium as carrier gas). The sum of $\mathrm{C}_{2} \mathrm{H}_{4}, \mathrm{C}_{2} \mathrm{H}_{6}, \mathrm{C}_{3} \mathrm{H}_{6}$ and $\mathrm{C}_{3} \mathrm{H}_{8}$ will further be referred to as $\mathrm{C}_{2+}$. The total outgoing mass of an individual gaseous compound was calculated by multiplying its gaseous mole fraction by the total flow rate $\left(\phi_{\mathrm{v}, \text { total }}=\phi_{\mathrm{v}, \mathrm{N} 2} \bullet\left(100 /\left(100-\Sigma \mathrm{mol} \%_{\text {gases }}\right)\right)\right)$ and molecular mass of that compound and subsequently integrating over time. The total gas yield on dry ash free basis was calculated by summing the yields of the individual gas compounds and dividing this value by the amount of daf biomass fed during the run.

\section{Pyrolysis oil:}

The procedure to determine the oil yield in the pilot plant reactor (section 4.2.2) is described in detail in an earlier publication ${ }^{30}$. For the FB+T-Reactor the daf oil yield was determined by a) summing the weight of oil collected in the ESP, intensive cooler and filter b) subtracting the amount of water which was already present in the feed c) dividing the resulting weight by the amount of daf biomass fed during the run. The composition of the oil was determined by various techniques as listed in Table 4.4.

\section{$\underline{\text { Char }}$}

The procedure to determine the char yield in the pilot plant reactor (section 4.2.2) is described in detail in an earlier publication ${ }^{30}$. The char yield (daf) for the FB+T-reactor was determined by dividing the mass of char collected inside the bed and on the filters minus the amount of minerals present in the feedstock by the amount of daf biomass fed during the run. So, it was assumed that all minerals present inside the feedstock end up in the char phase. It should be noted that the char yield determined as described above is independent of the conditions in the tubular reactor that is placed after the pyrolyzer. 
Table 4.4 Techniques used to analyze pyrolysis oil

\begin{tabular}{|l|l|l|l|}
\hline \multicolumn{1}{|c|}{ Compound } & \multicolumn{1}{c|}{ Technique } & \multicolumn{1}{c|}{ Analyzed Oil } & \multicolumn{1}{c|}{ Ref. } \\
\hline Water & Karl-Fischer titration & All condensers & (chapter 5)8 \\
\hline C,H,O,N & Elemental Analyzer & ESP FB+T-reactor & (chapter 5)8 \\
\hline $\begin{array}{l}\text { Pyrolytic Lignin } \\
\text { water insolubles) }\end{array}$ & $\begin{array}{l}\text { Cold water }\left(\sim{ }^{0} \mathrm{C}\right) \\
\text { precipitation }\end{array}$ & ESP FB+T-reactor & 23,24 \\
\hline Solids Content & Gravimetry & ESP FB+T-reactor & 25 \\
\hline $\begin{array}{l}\mathrm{M}_{\mathrm{w}} \text {-distribution } \\
(>100 \text { g/mol) }\end{array}$ & SEC (RID-detector) & $\begin{array}{l}\text { ESP FB+T-reactor } \\
\text { Spry column pilot plant }\end{array}$ & (chapter 6)26 \\
\hline $\begin{array}{l}\text { Aromatic and unsaturated } \\
\text { conjugated compounds }\end{array}$ & $\begin{array}{l}\text { SEC, ratio UV } \\
\text { and RID detector }\end{array}$ & ESP FB+T-reactor & (chapter 6)26 \\
\hline Volatile compounds & GC/MS (FID and MS detector) & ESP FB+T-reactor & 27 \\
\hline
\end{tabular}

\subsection{Heterogeneous vapor phase reactions}

To study the influence of the contact of vapors with char and minerals a series of experiments (Table 4.2) was carried out using the pilot plant. In these experiments the char content and mineral $(\mathrm{Na}+\mathrm{K})$ content was varied. The oil (organics and water), char and gas yields are plotted in Figure 4.3. The corresponding molecular weight distributions of the oils can be found in Figure 4.5. The organic and char yield as function of the $\mathrm{K}+\mathrm{Na}$ hold-up for all experiments is plotted in Figure 4.4. It should be kept in mind that the char and mineral hold-up (vol\% and wt $\%$ ) are expressed on total solid (char + sand + minerals) basis (see section 4.2.2).

\subsubsection{Effect of char hold-up: feedstock $(500 \mathrm{ppm} \mathrm{Na+K})$ derived char}

In the pilot plant, two experiments using Lingnocel 9 (with only $500 \mathrm{ppm} \mathrm{Na}+\mathrm{K}$ ) as feedstock and a char hold-up in the fluidized bed of 20 and 55 vol. $\%$ were carried out. The extent of possible vapor-char interactions was expected to increase with rising volumetric char hold-up. However, similar gas, oil and char yields were obtained, while also the amount of produced water was similar (Figure 4.3). No differences in molecular weight distribution of the oil phase could be observed either (Figure 4.5A). The experiments were repeated at a lower temperature of $400{ }^{\circ} \mathrm{C}$ and higher temperature of $530{ }^{\circ} \mathrm{C}$ (no data shown). Again no influence of char hold-up was observed in those cases. Data obtained in the FB+T-Reactor supported these observations. In this set-up the char hold up linearly increased during the course of an experiment from 0 till about 25 vol\%. However, no change in the permanent gas concentration and composition was observed as function of the experimental progress/char hold-up (Figure 4.6). These observations are in line with data obtained by Shen et $\mathrm{al}^{9}$, who performed similar experiments, but contradictory to earlier observations of Boroson et $\mathrm{al}^{13}$ and Ahuja et $\mathrm{al}^{22}$ who did observe an effect of char. Our data indicate that vapor-char interactions from an (almost) mineral free feedstock do not influence the product yields in our pilot plant noticeably. 


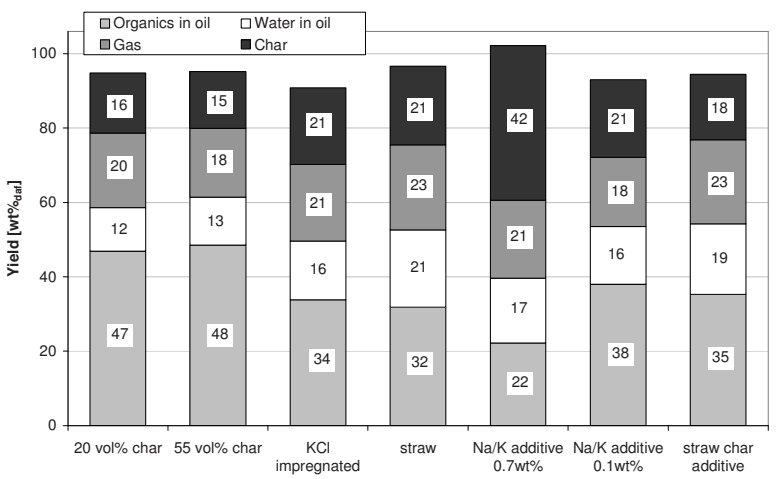

Figure 4.3 Yields, experimental conditions reported in Table 4.2
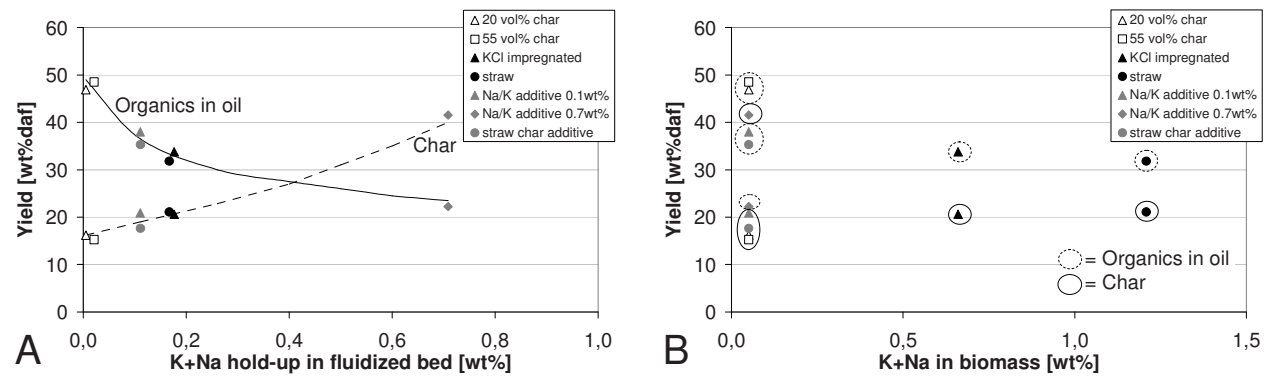

Figure 4.4 Organic yield as function of the wt $\%$ of $\mathrm{K}+\mathrm{Na}$ inside the fluidized bed and biomass particles
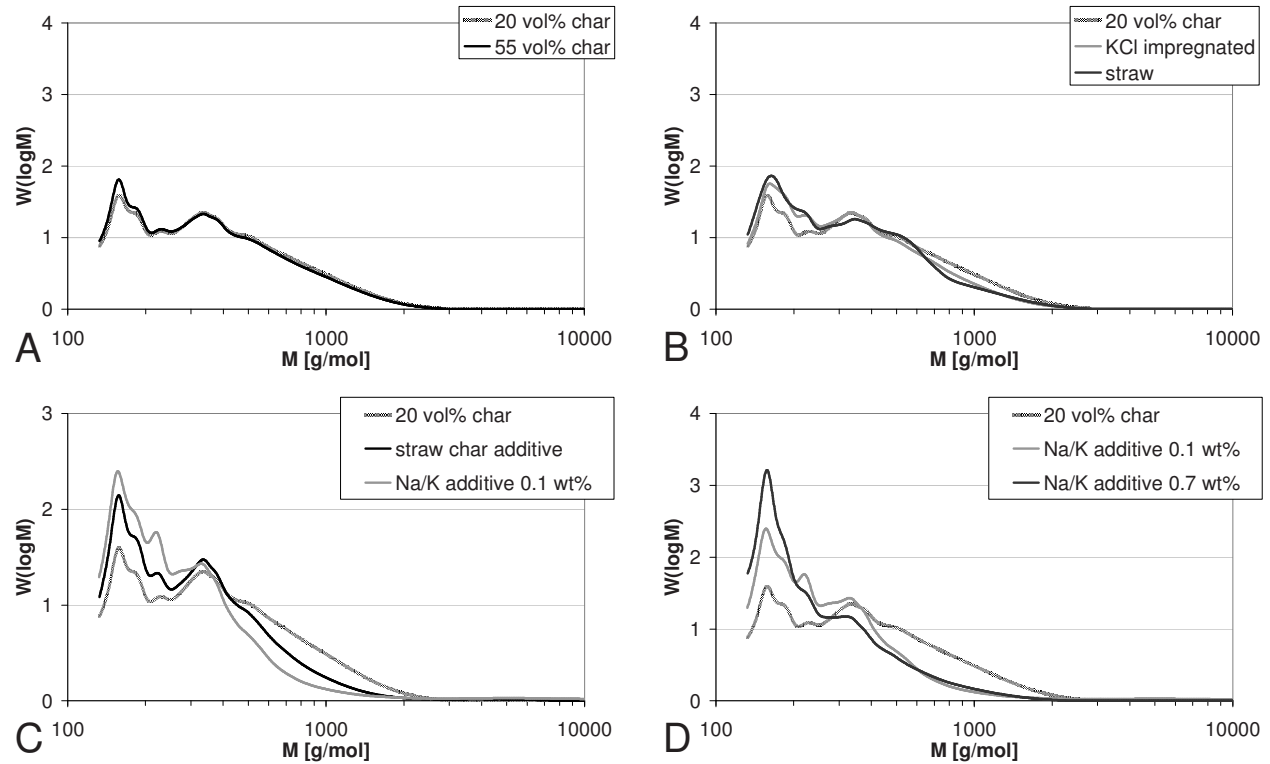

Figure 4.5 $\mathrm{M}_{\mathrm{w}}$-distribution of oils produced in pilot plant 


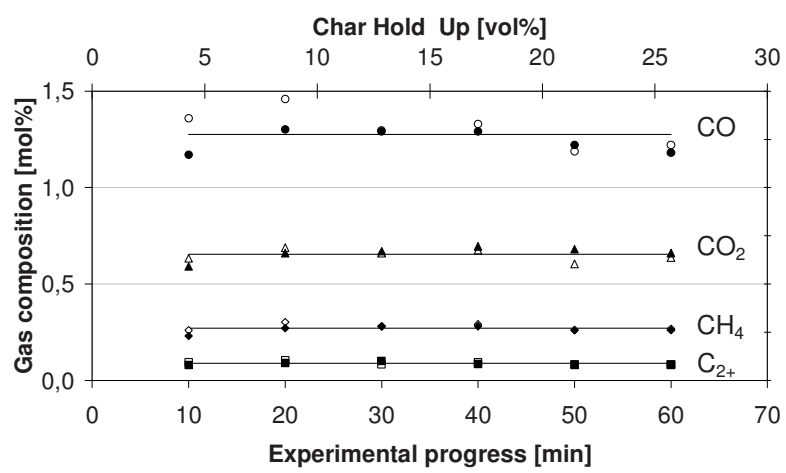

Figure 4.6 Gas composition as function of char-holdup/time in FB+T reactor. No tubular reactor installed, closed and open symbols denote two separate experiments.

\subsubsection{Effect $\mathrm{K}+\mathrm{Na}$ in feedstock}

Two experiments using different feedstocks high in $\mathrm{K} / \mathrm{Na}$ content were carried out. One experiment was carried out in the pilot plant using Lignocel 9 impregnated with $\mathrm{KCl}$. Because impregnation is an artificial way of increasing the mineral content of the feed, straw was also used as feed (Table 4.1). In both cases, the liquid organic yield dropped, the char and water yield increased (Figure 4.3) and the average molecular weight of the oil decreased (Figure 4.5B) compared to experiments carried out using untreated Lignocel 9. In addition, a slight increase in gas yield was observed for the "straw" experiment. Our data and the results reported in literature ${ }^{2,28,29}$ clearly show that the mineral content (especially $\mathrm{Na}$ and $\mathrm{K}$ ) inside the biomass has an important effect on the product yields and product characteristics. Because the use of a mineral rich feedstock also results in the formation of mineral rich char, it is not clear whether the observed effects are due to differences in reactions (rate, pathway) inside the reacting biomass particle (internal) or because of reactions of produced vapors with already existing char (external). This will be discussed in the following sections.

\subsubsection{Effect "external" $K+\mathrm{Na}$ on heterogeneous vapor phase reactions}

To reveal whether 'external minerals' can affect the extent of vapor phase reactions an additional series of experiments was carried out. In these experiments, untreated Lignocel 9 was used as feedstock, however mineral rich additives were added to the feed of the fluidized bed. These additives were either $\mathrm{Na} / \mathrm{K}$ salts (using two hold-ups, viz. 0.1 and $0.7 \mathrm{wt} \%$ ) or a mineral rich char originating from straw (straw char hold-up 25 vol. $\%$, $\mathrm{Na} / \mathrm{K}$ hold-up $0.1 \mathrm{wt} \%$ ). The organic oil yield decreased, while the char and produced water yield increased as compared to the "20 vol\% char" experiment (Figure 4.3). More gases were produced in the "straw char additive" experiment and the average molecular weight decreased for all experiments (Figure 4.3 and 5C, D), both phenomena suggesting some form of cracking. One experiment was carried out with a much larger amount of 
added salts to the bed: "Na/K additive 0.7 wt\%". The results in Figure 4.3 show that less oil and more gasses, water and char were produced and the average molecular weight of the oil was decreased in comparison with the experiment using $0.1 \mathrm{wt} \% \mathrm{Na} / \mathrm{K}$. The yield of char even doubled to $42 \mathrm{wt} \%$.

Our results clearly show that after leaving the biomass matrix vapors react on the (internal) surface of particles with inorganic matter to form additional char, water and an oil with a lower molecular weight. Heterogeneous vapor phase charring/polymerization reactions were more important than cracking reactions of vapors to gas.

\subsection{4 $\mathrm{Na}+\mathrm{K}$ in biomass versus $\mathrm{Na}+\mathrm{K}$ in the reactor $(\mathrm{FB})$}

A decline in organic yield and an increase in char yield were observed with increasing total $\mathrm{Na}+\mathrm{K}$ hold-up inside the fluidized bed reactor (Figure 4.4A). However, no relationship could be observed between the amount of $\mathrm{Na}+\mathrm{K}$ present inside the biomass feedstock and the yields of organics and char (Figure 4.4B). From these experimental data it can be concluded that in the studied range (Table 4.2+3) external interactions between the vapors and $\mathrm{Na} / \mathrm{K}$ rich solids do play a more significant role than the interactions between $\mathrm{Na} / \mathrm{K}$ and the (decomposing) biomass (internal). However several TGA (heating rate $10{ }^{\circ} \mathrm{C} / \mathrm{min}$ ) ${ }^{29,38}$ and Py-GC/MS ${ }^{39,40}$ (heating rate $>2000{ }^{\circ} \mathrm{C} / \mathrm{s}$ ) studies report that minerals like $\mathrm{K}$ and $\mathrm{Na}$ have an effect on the decomposition "weight loss" reactions of biomass, cellulose and hemicellulose. When adding for instance $\mathrm{KOH}$ to pine wood the temperature at which the highest weight loss rate was observed reduced significantly from 353 to $275^{\circ} \mathrm{C}^{38}$. Although minerals influence the initial decomposition reactions this could not be established in this study because of the predominance of external interactions between the vapors and $\mathrm{Na} / \mathrm{K}$ rich solids. More research is necessary to elucidate the effect of minerals on a (decomposing) biomass particle in absence of vapor-particle interactions.

\subsubsection{Concluding remarks}

The results clearly show that char itself, viz. the organic $\mathrm{C}, \mathrm{H}$ and $\mathrm{O}$ atoms in it, appear not to be catalytically active inside the fluidized bed reactor. However, the presence of minerals $(\mathrm{Na} / \mathrm{K})$ - either in the biomass matrix (native or impregnated) or external (as salt or in char), does influence the fast pyrolysis process. In our experiments external interactions between the vapors and $\mathrm{Na} / \mathrm{K}$ rich solids did play a more significant role than internal interactions between $\mathrm{Na} / \mathrm{K}$ and the (decomposing) biomass. Heterogeneous vapor phase charring/polymerization reactions were more important than cracking reactions of vapors to gas. From these results it is evident that the contact between minerals and vapors needs to be minimized to be able to obtain high oil yields. 


\subsection{Homogeneous vapor phase reactions}

Homogeneous vapor phase reactions from char free pyrolysis vapors were studied in the $\mathrm{FB}+\mathrm{T}$ reactor system. It is important to realize that the pyrolysis vapors that were introduced in the tubular reactor were already exposed for $\sim 1.5 \mathrm{~s}$ to the temperature in the fluidized bed reactor $\left(500{ }^{\circ} \mathrm{C}\right)$. The gas and oil yield as function of the tubular reactor conditions and the corresponding char yield in the fluid bed are shown in Figure 4.7. The mass balance closure is plotted in the same figure, and is around $90 \mathrm{wt} \%$ for all experiments. This gap is expected to be related to the loss of some volatile compounds which might be stripped from the condensation system due to the high $\Phi_{\mathrm{v}, \mathrm{N} 2} / \Phi_{\mathrm{m} \text {,biomass }}$ ratio applied (Table 4.3). Three identical runs were carried using the fluidized bed reactor alone to get an indication of the experimental error and are plotted as reference (designated as "0.0 s"). The product yields and oil composition show good reproducibility (Figures 4.7-4.13).

\subsubsection{Heterogeneous reactions on reactor wall}

In the downstream tubular reactor, heterogeneous reactions of vapors in contact with the (hot) stainless steel reactor wall cannot be excluded. Minor char deposits were visually observed on the tubular reactor wall. This is in accordance with previous results which showed that some char can be formed on various surfaces from a solids-free vapor stream $^{9}$. An estimation of the amount of char deposited on the tubular reactor wall was made after finishing all experiments. The $1 \mathrm{~m}$ tubular reactor was weighed, cleaned (by burning) and subsequently reweighed. Assuming the weight difference to be caused by only deposited char, this amount appeared to be only $0.1 \mathrm{wt} \%_{\text {daf }}$ (average over all runs with $1 \mathrm{~m}$ tubular reactor). To study the influence of a fivefold larger steel area on the vapor phase reactions the $1 \mathrm{~m}$ tubular reactor was filled with steel wool. The results were similar to these obtained without steel wool (Figure 4.7-4.10). Assuming that the increase in mass of the steel wool afterwards was due to char formation, this was again a negligible percentage $\left(+0.05 \mathrm{wt} \%_{\mathrm{daf}}\right)$ It can thus be concluded that the possible catalytic effect of the steel tubular reactor wall is insignificant.

\subsubsection{Yields: oil, gas, char}

The measured char yield in the fluid bed should of course be independent on the process conditions in the tubular reactor placed after the fluid bed. This was indeed the case, about $12 \mathrm{wt} \%_{\text {daf }}$ of char yield was obtained in all experiments. Char formation inside the tubular reactor could only be quantified indirectly. No solids were detected inside the pyrolysis oil $(<0.002 \mathrm{wt} \%)$ and, as already shown in section 4.4.1, an insignificant amount of char was deposited on the reactor wall. These results indicate that for the process conditions applied negligible amounts of char were formed from homogeneous vapor phase reactions. 
The oil and organic yield did follow the same trend since the water production was constant for all tubular reactor conditions (section 4.4.3). The oil and gas yield remained constant and were independent on residence time if the tubular reactor was operated at $400{ }^{0} \mathrm{C}$. At $500{ }^{0} \mathrm{C}$ and in the first $5 \mathrm{~s}$, a slight decrease in oil yield $\left(\sim 5 \mathrm{wt} \%_{\text {daf }}\right)$ and a similar increase in gas yield was observed. The oil and gas yield remained nearly constant hereafter. At $550{ }^{0} \mathrm{C}$, the oil yield decreased and gas yield increased with slightly more than $10 \mathrm{wt} \%_{\text {daf. }}$ The yields appeared to be almost completely stabilized with time up to 12 s. In literature it is regularly reported that the oil yield decreases continuously with increasing residence time (studied up to $3.5 \mathrm{~s}^{18,19,41}$ ). Our results show that this trend cannot be extrapolated to higher residence times. Boroson et al. ${ }^{14}$ postulated the existence of such a temperature dependent asymptote based on a measured constant oil yield at 800 ${ }^{0} \mathrm{C}$ for residence times between 1.6 and $2.0 \mathrm{~s}$. Although their maximum residence time of $2 \mathrm{~s}$ was not long enough to observe the asymptotes at typical pyrolysis temperatures, our data show that their postulation is indeed correct for temperatures between 400 and 550 ${ }^{0} \mathrm{C}$. Graham et al ${ }^{15}$ studied the vapor phase reactions during the pyrolysis of cellulose and also in that case asymptotic oil yields were obtained, but much faster than Boroson observed: within $1 \mathrm{~s}$ for temperatures in the range of $650-800{ }^{0} \mathrm{C}$. These results show that a temperature dependent asymptote is present provided that long enough vapor residence times are applied. With increasing temperature an increasing part of the pyrolysis vapors can crack to gases via homogeneous vapor phase reactions.

The effect of the vapor residence time and temperature on the yields of the individual gas compounds $\left(\mathrm{CO}, \mathrm{CO}_{2}, \mathrm{CH}_{4}, \mathrm{C}_{2+}\right)$ is shown in Figure 4.8. Based on thermodynamic calculations (RGibbs reactor in Aspen Plus) and experimental data of Lanza et al. ${ }^{21}$, water gas shift and methane reforming reactions are not expected to play a significant role in the temperature range used $\left(400-550{ }^{\circ} \mathrm{C}\right)$. Therefore, the change in especially $\mathrm{CO}_{2}, \mathrm{CO}$ $\mathrm{H}_{2} \mathrm{O}, \mathrm{CH}_{4}$ and $\mathrm{H}_{2}$ must originate directly from pyrolysis vapor reactions. According to Figure 4.7, no change in gas yield was observed if the tubular reactor was operated at 400 ${ }^{0} \mathrm{C}$ and also the gas yield of the individual compounds remained constant. The gas yields for all individual compounds increased with reactor severity for temperatures above 500 ${ }^{0} \mathrm{C}$. Especially the yield of $\mathrm{CO}$ was increasing with increasing reactor severity $(\sim 70 \%$ of additional formed gases on weight basis), while the yield of $\mathrm{CO}_{2}$ increased only marginally ( $10 \%$ of the additional formed gases on weight basis). The $\mathrm{C}_{2+}$ yield showed the largest relative increase, almost tripling at $550{ }^{0} \mathrm{C} / 12 \mathrm{~s}$. The $\mathrm{CH}_{4}$ yield doubled under those conditions. The increase of the $\mathrm{CO} / \mathrm{CO}_{2}$ ratio with the extent of vapor phase reactions (i.e. temperature, residence time) is in line with previous results obtained using batch wise operated pyrolysis reactors with subsequent tubular reactor using wood $^{14,16,17}$ and model compounds ${ }^{42-44}$ as feedstock. 
Although the pyrolysis oil yields do not $\left(400{ }^{0} \mathrm{C}\right)$ or marginally $\left(500{ }^{0} \mathrm{C}\right)$ change as a function of the residence time in the tubular reactor, it is not clear whether changes in composition by vapor to vapor reactions occur for these experiments. Additional analytical techniques were used to study these possible changes.

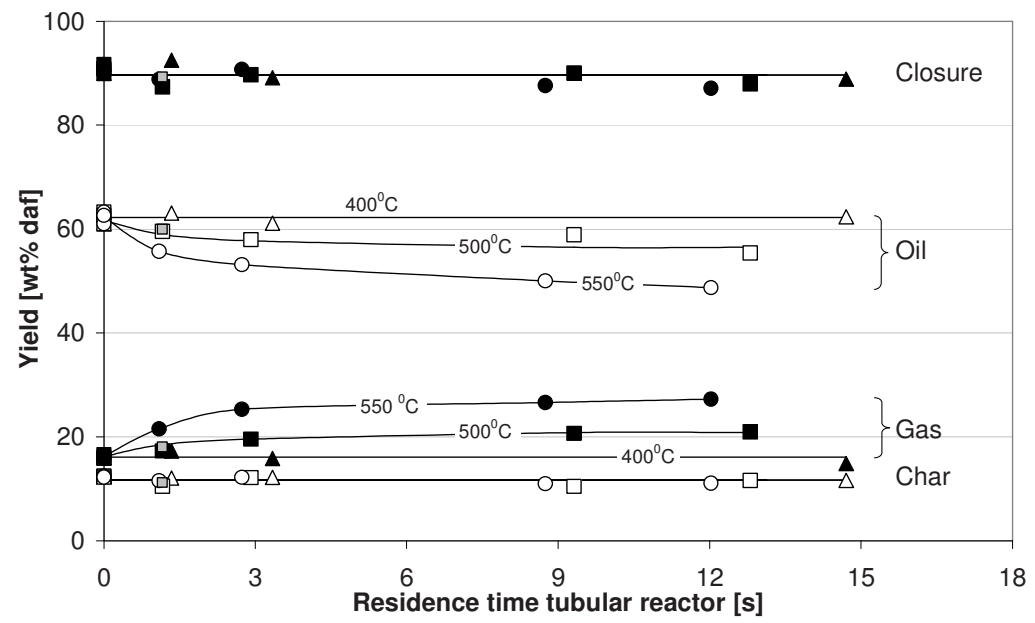

Figure 4.7 Yields at different tubular reactor temperatures and residence times, residence time in fluid bed $\sim 1.5 \mathrm{~s}\left(\mathbf{\Delta} \triangle=400{ }^{\circ} \mathrm{C}, \square \square=500{ }^{-} \mathrm{C}, \boldsymbol{\bigcirc} \bigcirc=550{ }^{\circ} \mathrm{C}, \square=\right.$ steel wool $\left.500{ }^{\circ} \mathrm{C}\right)$
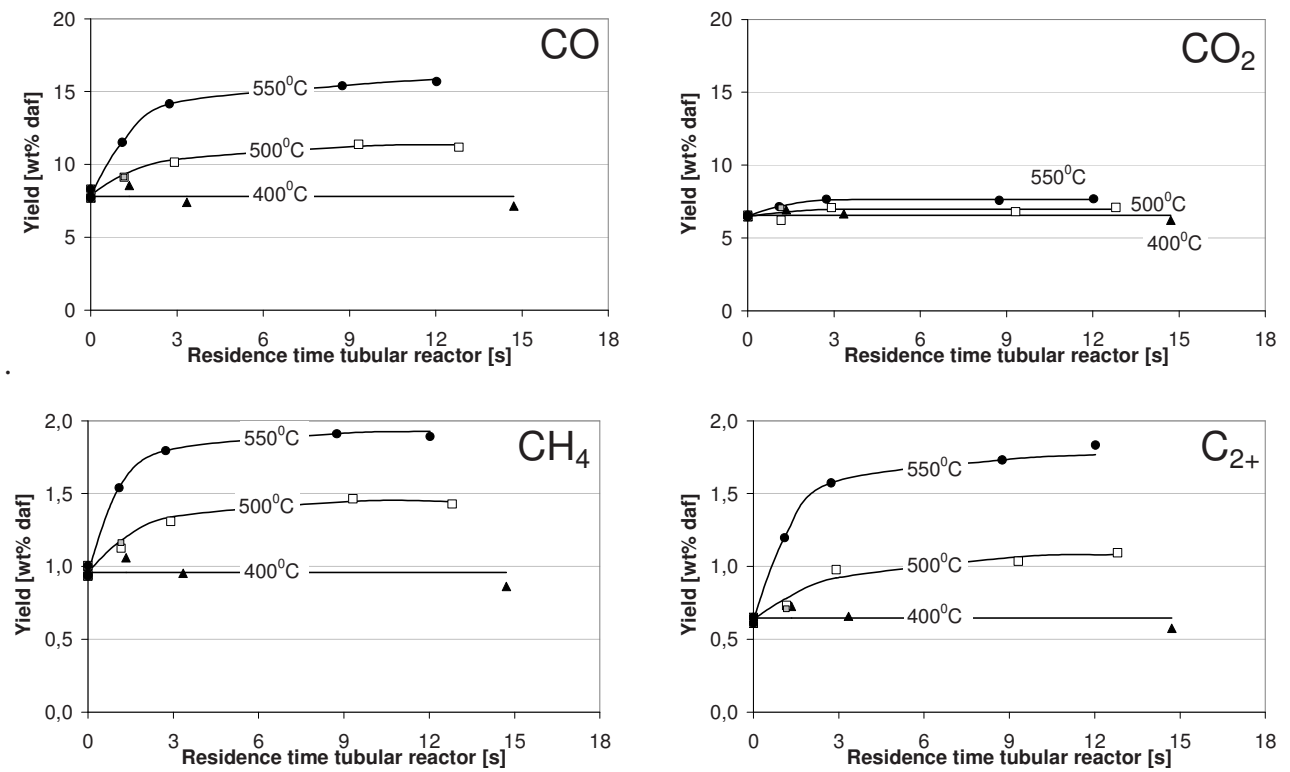

Figure 4.8 Gas yields at different tubular temperatures and residence times (triangle $=400{ }^{\circ} \mathrm{C}$, square $=500$ ${ }^{-} \mathrm{C}$, circle $=550{ }^{\circ} \mathrm{C}, \square=$ steel wool $500{ }^{\circ} \mathrm{C}$ ) 


\subsubsection{Water production}

According to literature, several dehydration reactions of pyrolysis vapors can occur, for example during the formation of isoeugenol ${ }^{42}$, furans ${ }^{43-45}$, ketene-structures ${ }^{43}$ (which can rehydrate to form acids) and several monosaccharides ${ }^{48}$ and anhydrosugars ${ }^{46}$. Condensation reactions of pyrolysis oil are known to take place even at room temperature $^{46}$. Possibly, water can also be formed via (bimolecular) condensation reactions inside the vapor phase. However, no differences in water production could be observed between the various experiments (Figure 4.9) indicating that dehydrations reactions occurred mainly inside the fluidized bed reactor $(\tau \sim 1.5 \mathrm{~s})$. An average water production value of $10.5 \mathrm{wt} \%$ was measured, with a standard deviation of $1.0 \mathrm{wt} \%$.

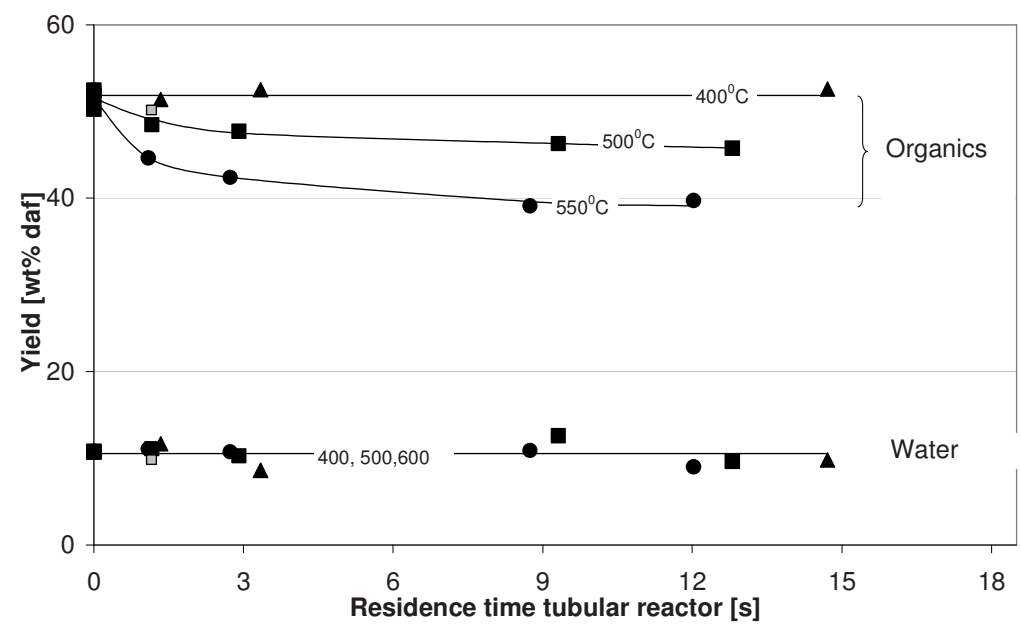

Figure 4.9 Yields of organics and produced water as a function of tubular temperature and residence time (triangle $=400{ }^{0} \mathrm{C}$, square $=500{ }^{-} \mathrm{C}$, circle $=550{ }^{\circ} \mathrm{C}, \square=$ steel wool $500{ }^{\circ} \mathrm{C}$ )

\subsubsection{Elemental composition of oil (organics)}

Considering that the water and char production were independent of the conditions in the tubular reactor, the change in elemental composition of the oil should directly be related to the change in elemental composition and yield of the gas phase. For the most severe conditions $-11 \mathrm{~m}$ tube, $550{ }^{\circ} \mathrm{C}$ - a calculated change in elemental oil composition of only $+1.1,+0.3$ and $-1.4 \mathrm{wt} \%$ for $\mathrm{C}, \mathrm{H}$ and $\mathrm{O}$ would be expected. In line with these expected small changes, the measured elemental composition appeared to be independent on the process conditions in the tubular reactor and similar to the one of the oil obtained directly after the fluidized bed reactor: $\mathrm{C}=57 \pm 0.8$ (stdev), $\mathrm{H}=6 \pm 0.9$ and $\mathrm{O}=36 \pm 0.2 \mathrm{wt} \%$ daf. 


\subsubsection{Molecular weight distribution}

The molecular weight distributions of the oils produced in the shortest $(1 \mathrm{~m}, \tau=1 \mathrm{~s})$ and longest $(11 \mathrm{~m}, \tau=12-15 \mathrm{~s})$ tubular reactor operated at 400,500 and $550{ }^{\circ} \mathrm{C}$ are plotted in Figure 4.10. The oil produced in the fluidized bed reactor alone is plotted as reference in the same figure $(0.0 \mathrm{~s})$. The area under the SEC curves is normalized to 1 , so the peak heights/area are not related to the actual yield of a molecular weight fraction, but to (a certain extent to ${ }^{(\text {chapter } 6) 26}$ ) the relative presence of it inside the oil.

A small decrease in average molecular weight with respect to the reference oil was observed for the experiments carried out in the tubular reactor operated at $400{ }^{\circ} \mathrm{C}$. It was shown before (Figure 4.8) that no additional gases were formed at this temperature, so vapor molecules are likely to have rearranged and cracked to smaller ones that end up in the oil phase upon condensation.

A significant reduction in the peak intensity around $200-350 \mathrm{~g} / \mathrm{mol}$ was observed when the tubular reaction system was operated at $500{ }^{\circ} \mathrm{C}$. The centre plateau at $200-350 \mathrm{~g} / \mathrm{mol}$ disappeared completely at $550{ }^{\circ} \mathrm{C}$ and a vapor phase residence time of $12.0 \mathrm{~s}$ indicating cracking reactions. The occurrence of cracking reactions is supported by the aforementioned increase in gas yield at the expense of oil yield (section 4.4.2). The oil produced with the tubular reactor operated at 500 and $550{ }^{\circ} \mathrm{C}$ did contain relatively more compounds with higher molecular weight $(>1000 \mathrm{~g} / \mathrm{mol})$ than the reference oil and the oil produced in the $\mathrm{FB}+\mathrm{T}$ at $400{ }^{0} \mathrm{C}$. It cannot be unambiguously concluded whether these compounds are really formed by polymerization reactions or if it is only a relative increase which can be explained by the disappearance of low molecular weight compounds due to the formation of gases. Because no increase in pyrolytic lignin content (see next paragraph) and no noticeable increase in water production (condensation reactions) was observed, the second explanation is favored. 

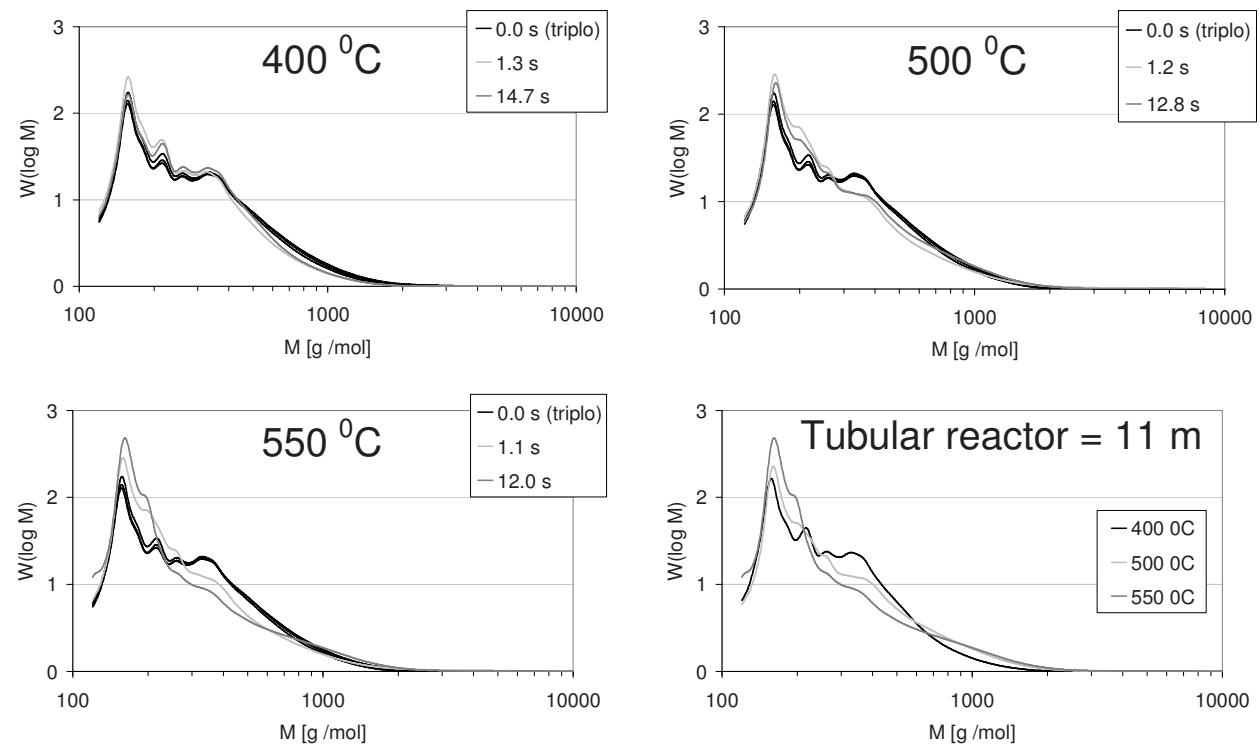

Figure 4.10 $\mathrm{M}_{\mathrm{w}}$-distribution of pyrolysis oil. Time gives residence time in tubular reactor system.

\subsubsection{Pyrolytic lignin content}

In Figure 4.11 the pyrolytic lignin yield (water insolubles) is plotted as function of the vapor phase residence time. Pyrolytic lignin is known to account (partly) for the high molecular weight compounds present in pyrolysis oil ${ }^{10}$. The pyrolytic lignin content dropped at $400{ }^{0} \mathrm{C}$ which is in line with the $\mathrm{M}_{\mathrm{w}}$-distribution results. This supports the aforementioned finding that vapor molecules do crack at $400{ }^{0} \mathrm{C}$ to smaller molecules, although no oil yield changes were observed. The pyrolytic lignin yield dropped further upon increasing the tubular reactor temperature to 500 and $550{ }^{\circ} \mathrm{C}$, which is in line with the observed decline in average molecular weight of the oils. These results and the results on the $\mathrm{M}_{\mathrm{w}}$-distribution of the oils suggest that cracking reactions were dominant over polymerization reactions in the studied range $\left(400-550{ }^{\circ} \mathrm{C} / 1-15 \mathrm{~s}\right)$.

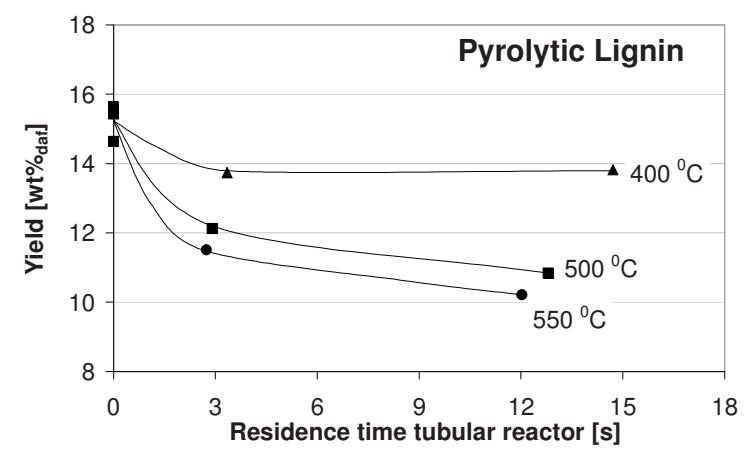

Figure 4.11 Pyrolytic lignin (water insolubles) 


\subsubsection{Aromatic and conjugated (AC) compounds}

The $\int \mathrm{UVdv} / \int \mathrm{RIDdv}$ ratio which is associated with the relative content of the aromatic and conjugated (AC) compounds in the oil ${ }^{\text {(chapter } 6) 26}$ is plotted as function of the tubular reactor severity in Figure 4.12. The $\int \mathrm{UVdv} / \int \mathrm{RIDdv}$ ratio for the oil remained constant for the experiments carried out at $400{ }^{\circ} \mathrm{C}$. The amount of $\mathrm{AC}$ compounds appeared to increase with increasing tubular reactor severity. In literature it is regularly reported that pyrolysis oil produced at higher temperatures contains more aromatics ${ }^{18,35,47}$. Aromatization reactions are reported to take place at higher temperatures ${ }^{47}$. A second explanation opposite to the formation of $\mathrm{AC}$ compounds is that non $\mathrm{AC}$ compounds might be gasified which should be accompanied by an oil yield decrease and a relative higher abundance of AC compounds. Although it is unknown if a linear relation exist between the $\int \mathrm{UVdV} / \int \mathrm{RIDdv}$ ratio and the concentration of $\mathrm{AC}$ compounds, the yield corrected $\int U V d v / \int R I D d v$ ratio's are plotted as well in Figure 4.12 (open symbols). The yield corrected $\int U V d v / \int R I D d v$ ratio was independent of the tubular reactor severity. This suggests that higher concentrations of aromatics as often observed in the oil with an increase in pyrolysis severity does not necessarily imply the net formation of aromatics, but can also be explained by the net disappearance of the non-aromatic fraction from the oil.

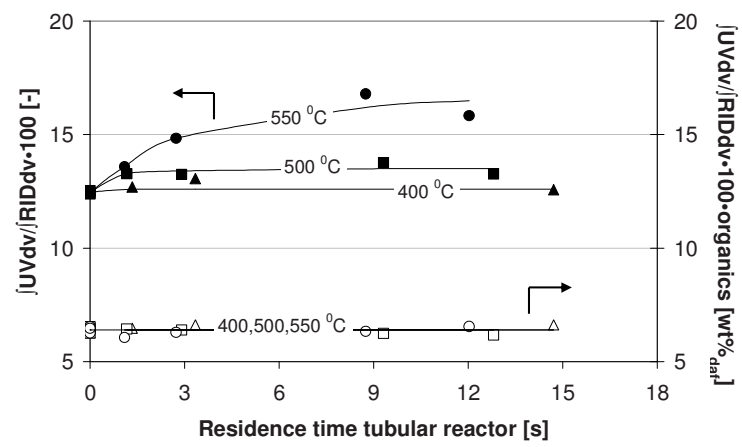

Figure 4.12 $\int \mathrm{UVdv} / \int \mathrm{RIDdv}$ ratio for pyrolysis oil (associated with aromatic and conjugated compounds)

\subsubsection{GC/MS: volatile compounds}

An indication of the fraction of volatile compounds in the pyrolysis oil was obtained by using GC/MS. The total yield of volatile compounds, levoglucosan and the yield of four lumped groups (non aromatic aldehydes, pyrans, guaiacols, lignin derived phenols) are plotted in Figure 4.13 as function of the tubular reactor temperature $\left(400,500,550{ }^{\circ} \mathrm{C}\right)$ and residence time $(0-15 \mathrm{~s})$. The detected and quantified compounds in these four groups are listed in Table 4.5. 
At $400{ }^{\circ} \mathrm{C}$, the sum of total GC/MS detectables ( volatiles) increased with residence time, while no oil yield changes were observed at this temperature. This shows that also at 400 ${ }^{0} \mathrm{C}$ vapor to vapor reactions occur and heavier molecules are likely to be cracked to more volatile ones. This is in line with the SEC analysis result and the pyrolytic lignin content (section 4.4.5 and 4.4.6). At higher temperatures $\left(500\right.$ and $550{ }^{\circ} \mathrm{C}$ ), the yield of volatile compounds decreased with residence time, but also an increase in gas yield was observed for these experiments. Summing the gas and volatile yield showed that its value increased with residence time for all temperatures. So, overall, heavier molecules were cracked to smaller ones (either volatiles or gases) for all temperatures. From this we conclude that the overall formation of GC/MS detectable volatile compounds from heavier vapor components is slower than the overall cracking of GC/MS detectable volatiles to gases at 500 and $550{ }^{\circ} \mathrm{C}$.

Non aromatic aldehydes are reported to mainly originate from pyrolysis of hemicellulose and cellulose $\mathrm{s}^{43,44}$. The yield of non aromatic aldehydes initially (up to $\sim 3 \mathrm{~s}$ ) increased for all temperatures after which a decline was observed for the two highest temperatures only. Aldehydes appear to be formed from heavier molecules during pyrolysis vapor phase reactions even at temperatures as low as $400{ }^{0} \mathrm{C}$ for which no oil yield changes were observed. Since an increase in $\mathrm{CO}$ yield was observed only at 500 and $550{ }^{\circ} \mathrm{C}$ and aldehyde type of compounds are reported to be cracked to $\mathrm{CO}^{43,44}$, it is likely that the decline in aldehyde yield can be explained by subsequent decarbonylation reactions. Overall, part of the heavier hydrocarbons seem to be converted to non aromatic aldehydes $\left(>400{ }^{\circ} \mathrm{C}\right)$ and $\mathrm{CO}\left(>500{ }^{\circ} \mathrm{C}\right)$.

Pyrans originating from the degradation of several (poly)saccharides ${ }^{48}$ appeared not to be stable in the range of 400 to $550{ }^{\circ} \mathrm{C}$, as is shown in Figure 4.13. These results proof again that at $400{ }^{\circ} \mathrm{C}$ internal rearrangement reactions took place although no changes in yields were observed.

Levoglucosan is one of the most abundant products in pyrolysis oil and originate primarily from cellulose ${ }^{43,48,49}$. Figure 4.13 shows that the levoglucosan yield was constant at $400{ }^{\circ} \mathrm{C}$. At higher temperatures, the small increase in levoglucosan yield might be explained by further cracking of cellulose decomposition products (e.g. cellobiose). In literature several reactions schemes of levoglucosan are reported. Cracking reactions of levoglucosan to lower molecular weight products like furans and aldehydes $^{43,49}$ but also polymerization reactions of levoglucosan to form polysaccharides ${ }^{49}$ are included in those schemes. Our results did show that such kind of reactions do not take place inside a homogeneous vapor phase at temperatures between 400 and $550{ }^{\circ} \mathrm{C}$. 
In literature it is reported that softwood lignins typically degrade to guaiacol-type of compounds $^{50}$ and guaiacols are reported to be converted to phenols and catchols ${ }^{35,42,50}$. The methoxy group $\left(-\mathrm{OCH}_{3}\right)$ was suggested be an important source for the formation of the small volatile species $\left(\mathrm{CO}, \mathrm{CO}_{2} \text { and } \mathrm{CH}_{4}\right)^{42} .2 .3 \mathrm{wt} \%$ daf of guaicaols were detected inside the pyrolysis oil collected just after the fluidized bed reactor. Although at $400{ }^{\circ} \mathrm{C}$ guaiacols appeared to be stable, they disappeared almost completely with increasing severity in the tubular reactor. An increase in gas yield and lignin derived phenols was observed simultaneously at 500 and $550{ }^{\circ} \mathrm{C}$ which is expected based on the reaction pathway proposed in literature.
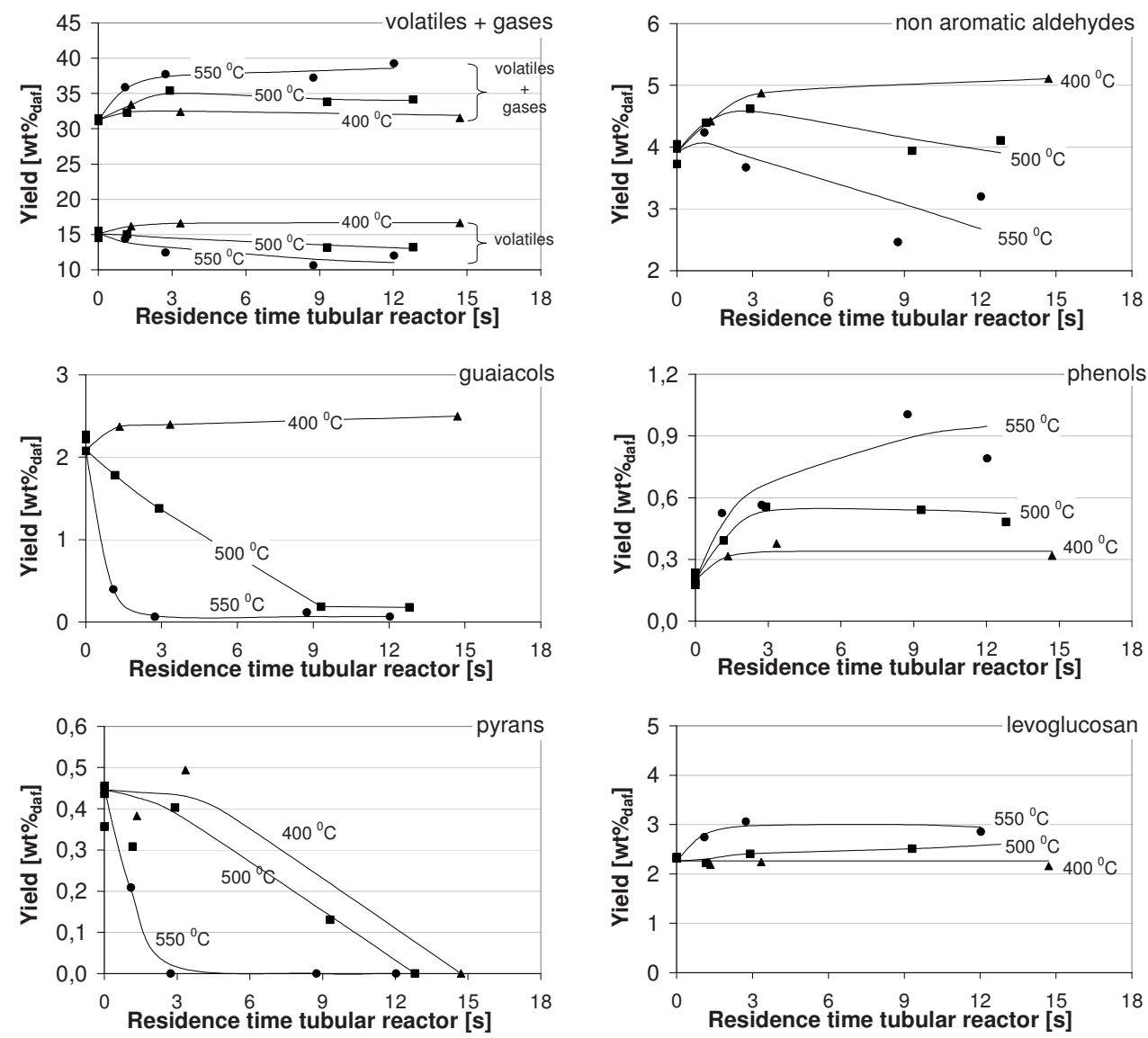

Figure 4.13 Yields of GC/MS detectable volatile compounds (denoted as volatiles in figure) in $\mathrm{FB}+\mathrm{T}$ reactor (triangle $=400{ }^{\circ} \mathrm{C}$, square $=500{ }^{\circ} \mathrm{C}$, circle $=550{ }^{\circ} \mathrm{C}$ ) 
Table 4.5 Lumped classes of pyrolysis liquid compounds, quantified by GC/MS (denoted as volatiles in Figure 4.13)

\begin{tabular}{|l|l|}
\hline Class & Quantified compounds \\
\hline Non aromatic aldehydes & $\begin{array}{l}\text { hydroxy-acetaldehyde, 3-hydroxy-propionaldehyde, crotonaldehyde, } \\
\text { butandial, 2-methyl-propanal }\end{array}$ \\
\hline Pyrans & 3-hydroxy-5,6-dihydro- (4H)-Pyran-4-one \\
\hline \multirow{3}{*}{ Phenols } & $\begin{array}{l}\text { phenol, cresol (o,m,p), dimethyl-phenol (2,5 and 2,6), } \\
\text { trimethyl-phenol (2,3,6 and 2,4,6), ethyl phenol (2 and 3 and 4), } \\
\text { trimethyl-derivative of phenol, (2,3,4- of 2,4,5-), 2-hydroxy-benzaldehyde, } \\
\text { 2-hydroxy-4-methylbenzaldehyde }\end{array}$ \\
\hline Guaiacols & $\begin{array}{l}\text { guaiacol, 4-methyl-guaiacol, 4-ethyl-guaiacol, 4-vinyl-guaiacol, } \\
\text { 4-allyl-guaiacol, (eugenol), 4-propenyl-(cis/trans)-guaiacol, (=isoeugenol), } \\
\text { vanillin, homovanillin, coniferyl alcohol, acetoguajacone, propioguaiacone, } \\
\text { guaiacyl acetone, coniferylaldehyde, } \\
\text { 4-hydroxy-3-methoxy-benzoic acid methyl ester }\end{array}$ \\
\hline
\end{tabular}

\subsubsection{Effect concentration on polymerization reactions}

The results described in section 4.4.2 till 4.4.8 suggest that cracking reactions were dominant over polymerization reactions in the studied range $\left(\mathrm{C}_{\text {gases+vapors }}=9 \mathrm{vol} \%, 400-\right.$ $550{ }^{0} \mathrm{C} / 1-15 \mathrm{~s}$ ). No increase in char yield, water production (linked to condensation reactions), pyrolytic lignin content and absolute molecular weight was observed which are all indicators for the occurrence of polymerization reactions. It should be emphasized that nitrogen diluted pyrolysis vapor streams were used (because of the fluid bed technology) and the concentration of the vapors is thus low. Polymerization reactions are expected to be bi-molecular and its rate thus expected to be concentration dependent. Since in literature no data are reported about the effect of pyrolysis vapor concentration on homogeneous vapor phase reactions some preliminary tests were carried out with a three times higher concentration $\left(\mathrm{C}_{\text {gasestvapors }}=27 \mathrm{vol} \%, \tau=3 \mathrm{~s}, \mathrm{~T}=400\right.$ and $\left.500{ }^{\circ} \mathrm{C}\right)$. The higher concentration was reached by reducing the reactor diameter (ID $5.5 \mathrm{~cm}$ versus 10 $\mathrm{cm})$ and by reducing the minimum fluidization velocity $\left(\mathrm{d}_{\mathrm{p} \text {,sand }}=200 \mu \mathrm{m}\right.$ versus $\mathrm{d}_{\mathrm{p} \text {, sand }}=$ 200-300 $\mu \mathrm{m}$ ). No decrease in oil yield was observed for the 27 vol\% compared to the standard runs with a vapor and gas concentration of 9 vol\%. The molecular weight distributions of the resulting oils are shown in Figure 4.14. No additional polymerizations reactions appeared to occur for the more concentrated pyrolysis vapor stream (27 vol\%). So, the findings reported in this study are expected to be valid for more concentrated vapor streams as well. 


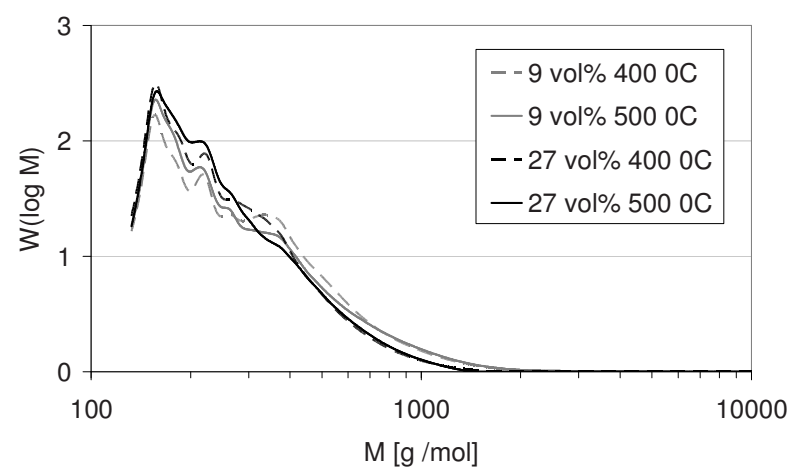

Figure 4.14 Effect of vapor/gas concentration on the $\mathrm{M}_{\mathrm{w}}$-distributions of the oils

\subsection{Kinetics, mechanism and modeling of vapor phase reactions}

The degradation of biomass is traditionally described via three parallel first order reactions to gas, oil and char $^{51,52}$. More comprehensive pyrolysis reaction models include homogeneous vapor phase reactions. The background of some of these models is discussed below in relation to the results obtained in this study.

Homogeneous vapor to gas reactions are often modelled using simple first order kinetics $^{19,20,41}$. Baumlin et al. ${ }^{19}$ constructed an Arrhenius plot of the first order rate constants of vapor to gas as reported in literature. The calculated Arrhenius constants for our own results $\left(500 / 550{ }^{0} \mathrm{C}\right.$, first $2 \mathrm{~s}$, isothermal plug flow model, $\mathrm{k}_{0}=1.8 \cdot 10^{5} \mathrm{~s}^{-1}, \mathrm{E}_{\mathrm{a}}=$ $9.7 \cdot 10^{4} \mathrm{~J} / \mathrm{mol}$ ) lie within the range of literature data. However, the spread in reported $\mathrm{k}$ values was large with differences up to a factor 15 . This spread in reported k-values was attributed to the difference in feedstocks (type, particle size), reactor (type, heating rate, reactor material) and calculation procedures ${ }^{14,19}$. Although the aforementioned model can predict the trend for short vapor residence times, it cannot predict the asymptotes in oil yield we did observe at prolonged vapor residence times (Figure 4.7). These asymptotes can be predicted if not the actual oil yield, but the difference between the actual and the stable oil yield (i.e. minimum oil yield at a specific $\mathrm{T}$ ) is used in the kinetic expression. However, such models appear to underpredict the conversions at short vapor phase residence times ${ }^{14}$ probably due to the presence of vapors with different reactivities.

Some researchers ${ }^{14,16-18}$ extended the concept of first order oil vapor to gas reactions by introducing several parallel first order vapor to gas cracking reactions. Boroson et al. ${ }^{14}$ and Stiles et al. ${ }^{18}$ assumed an infinite number of reactions to occur (distributed activation energy model) while Rath et al. ${ }^{16,17}$ divided the pyrolysis vapors into three reactive 
fractions. Such models are able to predict the asymptotes as observed in this study, but do not take into account any type of vapor to vapor reactions which were proven to occur in this study (section 4.4.2). Antal ${ }^{31}$ took those types of reactions into account in his model by including two parallel first order vapor reactions: one to permanent gases and the other one to stable vapors. Missing in Antal's model is a distinction between the reactivity of the different type of vapors originating from the biomass matrix (cellulose, hemicellulose and lignin).

Combination of the work of Boroson et al. ${ }^{14}$ and Antal $^{31}$ would yield a model that represents the homogeneous vapor phase reactions better. However, our work has shown that heterogeneous vapor reactions have a large influence on oil yield and composition as well. So far, and to our knowledge little to nothing has been done on the description and modeling of these heterogeneous vapor phase reactions.

The systematic approach dealing with the heterogeneous and homogeneous vapor phase reactions as carried out in this study can not only help to obtain a better understanding of the complex pyrolysis system but also elucidate the feasibility of modelling such system reliably. We believe that a generic mathematical description of the pyrolysis reactions either leads to a dangerous oversimplification or to a model with far too many (unknown) fit parameters. To our opinion, and at this point in time, simple models based on measurable parameters supported by good understanding of the actual phenomena taking place (decomposition and vapor phase reactions) allows for the most reliable prediction / extrapolation of the performance just outside the measured area for which the models were derived.

\subsection{Engineering viewpoint}

Several reactor types for fast pyrolysis processes have been and are being developed like i) bubbling fluidized bed ii) transported bed iii) circulating fluidized bed iii) ablative pyrolysis iv) auger and v) vacuum pyrolysis. Their advantages and disadvantages are described extensively in literature ${ }^{1,2,5,12,53}$. Three statements which are important from an engineering point of view are formulated based on our experimental results.

1. It is not necessary to remove ash poor char $(\mathrm{C}, \mathrm{H}, \mathrm{O})$ directly from the hot pyrolysis vapor stream

No changes in yields and oil composition were observed as function of (mineral poor) char hold-up (section 4.3.1). Consequently it is not necessary to remove pure char $(\mathrm{C}, \mathrm{H}, \mathrm{O})$ from the vapors. It should be noted that it is only possible to obtain an ash poor char from an ash poor feedstock. For this, either a clean feedstock like pine wood needs to be used or the minerals present in the biomass needs to be removed beforehand by a 
pre-treatment step. Research did show that minerals can be removed by a relatively simple washing step using water ${ }^{28}$.

\section{The contact time between vapors and minerals needs to be minimized}

Minerals, whether incorporated in the char matrix or not, appear to be detrimental for the pyrolysis oil yield. Contact between minerals and pyrolysis vapors should be avoided to prevent a decrease in oil yield. This can either be done by reducing the mineral concentration inside the reactor (for example prevent accumulation in continuous circulating processes) or by reducing the residence time of the vapors in the mineral rich part of the pyrolysis unit.

3. Pyrolysis vapors (mineral poor) can be exposed to temperatures up to $400{ }^{\circ} \mathrm{C}$ for long times

At $400{ }^{0} \mathrm{C}$, homogeneous vapor phase reactions do not influence the fast pyrolysis process in terms of oil yield. Rapid cooling of the vapors to ambient temperatures as typically reported in literature is thus not necessary ${ }^{1-6}$. Although some extent of vapor to vapor cracking was observed at $400{ }^{\circ} \mathrm{C}$, this was not accompanied by changes in oil yield. It should be noted that the pyrolysis vapors were produced at a typical pyrolysis temperature of $500{ }^{\circ} \mathrm{C}$ and statement 3 may not be valid for lower pyrolysis temperatures.

\subsection{Conclusions}

Heterogeneous and homogeneous reactions of pyrolysis vapors from pine wood were studied using respectively a fluidized bed reactor $\left(500{ }^{0} \mathrm{C}, \sim 0.8 \mathrm{~kg} / \mathrm{hr}\right)$ and a fluidized bed reactor $\left(500{ }^{0} \mathrm{C}, 0.15 \mathrm{~kg} / \mathrm{hr}\right)$ connected to a tubular reactor $\left(1-15 \mathrm{~s}, 400-550{ }^{0} \mathrm{C}\right)$.

Char itself, viz. the organic $\mathrm{C}, \mathrm{H}$ and $\mathrm{O}$ atoms, appeared not to be catalytically active inside the fluidized bed reactor. However, the presence of minerals $(\mathrm{Na} / \mathrm{K})$-either in the biomass matrix (native or impregnated) or external (as salt or in char), does influence the fast pyrolysis process. In our experiments external interactions between the vapors and $\mathrm{Na} / \mathrm{K}$ rich solids did play a more significant role than internal interactions between $\mathrm{Na} / \mathrm{K}$ and the (decomposing) biomass. Heterogeneous vapor phase charring/polymerization reactions were more important than cracking reactions of vapors to gas.

Pyrolysis vapors were also found to be reactive in the absence of minerals. With increasing temperature an increasing part of the pyrolysis vapors cracked to gases via homogeneous vapor phase reactions. Our results show that a temperature dependent oil yield asymptote is reached provided that long enough vapor residence times are applied $\left(400{ }^{\circ} \mathrm{C}: 62 \mathrm{wt} \%_{\text {daf }}, 500{ }^{\circ} \mathrm{C}: 57,550{ }^{\circ} \mathrm{C}: 49\right)$. At a vapor temperature of $400{ }^{\circ} \mathrm{C}$, the oil and gas yield were independent on the residence time, but homogeneous vapor to vapor 
reactions were proven to occur. In the studied range $\left(400-550{ }^{0} \mathrm{C}, 1-15 \mathrm{~s}\right)$ homogeneous cracking reactions were dominant over polymerization reactions. A decrease in average molecular weight, lignin content and an increase in gas yield (especially $\mathrm{CO}$ ) and phenols (GC/MS) was observed which are all indicators for cracking reactions while no increase in char yield and water production was observed which are indicators for the occurrence of polymerization reactions. It was shown that literature models consider the homogeneous and heterogeneous vapor phase reactions only to a limited extent.

Based on this work three statements which are important from an engineering point of view could be formulated:

1. It is not necessary to remove ash poor char $(\mathrm{C}, \mathrm{H}, \mathrm{O})$ directly from the hot pyrolysis vapor stream,

2. The contact time between vapors and minerals, whether or not incorporated in the char matrix, needs to be minimized,

3. Pyrolysis vapors (mineral poor) can be exposed to temperatures up to $400{ }^{\circ} \mathrm{C}$ for long times. 


\section{References}

1. D. Mohan, C.U. Pittman, P.H. Steele, Pyrolysis of wood/biomass for bio-oil: a critical review, Energy and Fuels, 20, 848-889, 2006

2. R.H. Venderbosch W. Prins, Fast pyrolysis technology development, Biofuels. Bioprod. Biorefin., 4, 178-208, 2010

3. S. Czernik, A.V. Bridgwater, Overview of applications of biomass fast pyrolysis oil, Energy and fuels, 18, 590-598, 2004

4. A.V. Bridgwater, Review of fast pyrolysis of biomass and product upgrading, Biomass and Bioenergy, 2011, article in press

5. A.V. Bridgwater, D. Meier, D. Radlein, An overview of fast pyrolysis of biomass, Org. Geochem., 30, 1479-14931, 1999

6. S.R.A. Kersten, X. Wang, W. Prins, W.P.M. van Swaaij, Biomass pyrolysis in a fluidized bed reactor. Part 1: literature review and model simulations, Ind. Eng. Chem. Res., 44, 8773-8785, 2005

7. T.J. Haas, M.R. Nimlos, B.S. Donohoe, Real-time and post-reaction microscopic structural analysis of biomass undergoing pyrolysis, Energy and Fuels, 23, 3810 - 3817, 2009

8. E. Hoekstra, J.A. Hogendoorn, X Wang, R.J.M Westerhof, S.R.A. Kersten, W.P.M van Swaaij, M.J. Groeneveld, Fast pyrolysis of biomass in a fluidized bed reactor: in situ filtering of the vapors, Ind. Eng. Chem. Res., 48, 4744 - 4756, 2009

9. J. Shen, X.S. Wang, M. Garcia-Perez, D. Mourant, M.J. Rhodes, C.Z. Li, Effects of particle size on the fast pyrolysis of oil mallee woody biomass, Fuel, 88, 1810-1817, 1999

10. R.J.M. Westerhof, D.W.F. Brilman, W.P.M. Van Swaaij, S.R.A. Kersten, Effect of temperature in fluidized bed fast pyrolysis of biomass: oil quality assessment in test units, Ind. Eng. Chem. Res., 49, 1160-1168, 2010

11. M. Garcia-Perez, X.S. Wang, J. Shen, M.J. Rhodes, F. Tian, W.J. Lee, H. Wu, C.Z. Li, Fast pyrolysis of oil mallee woody biomass: effect of temperature on the yield and quality of pyrolysis products, Ind. Eng. Chem. Res., 47, 1846-1854, 2008

12. D.S. Scott, P. Majerski, J. Piskorz, D. Radlein, A second look at fast pyrolysis of biomass - the RTI process, J. Anal. Appl. Pyrolysis, 51, 23-37, 1999

13. M.L. Boroson, J.B. Howard, J.P. Longwell, W.A. Peters, Heterogeneous cracking of wood pyrolysis tars over fresh wood char surfaces, Energy and Fuels, 3, 735-740, 1989

14. M.L. Boroson, J.B. Howard, J.P. Longwell, W.A. Peters, Product yields and kinetics from the vapour phase cracking of wood pyrolysis tars, AIChE Journal, 35, 120-128, 1989

15. R.G. Graham, M.A. Bergougnout, B.A. Freel, The kinetics of vapour-phase cellulose fast pyrolysis reactions, Biomass and Bioenergy, 7, 33-47, 1994

16. J. Rath, G. Staudinger, Cracking reactions of tar from pyrolysis spruce wood, Fuel, 80, 1379-1389, 2001

17. J. Rath, G. Staudinger, Vapour phase cracking of tar from pyrolysis of birch wood, Thermal Science, 5, 83-94, 2001

18. H.N. Stiles, R. Kandiyoti, Secondary reactions of flash pyrolysis tars measured in a fluidized bed pyrolysis reactor with some novel design features, Fuel, 68, 275-282, 1989

19. S. Baumlin, F. Broust, M. Ferrer, N. Meunier, E. Marty, J. Lede, The continuous self stirred tank reactor: measurement of the cracking kinetics of biomass pyrolysis vapours, Chem. Eng. Sci., 60, 41-55, 2005

20. P. Morf, P. Hasler, T. Nussbaumer, Mechanisms and kinetics of homogenous secondary reactions of tar from continuous pyrolysis of wood chips, Fuel, 81, 843-853, 2002

21. R. Lanza, D. Dalle Nogare, P. Canu, Gas phase chemistry in cellulose fast pyrolysis, Ind. Eng. Chem. Res., 48, 1391-1399, 2009

22. P. Ahuja, S. Kumar, P.C. Singh, A model for primary and heterogeneous secondary reactions of wood pyrolysis, Chem. Eng. Technol., 19, 272-282, 1996

23. B. Scholze, D. Meier, Characterization of the water-insoluble fraction from pyrolysis oil (pyrolytic lignin). Part I. Py-GC/MS, FTIR, and functional groups, J. Anal. Appl. Pyrolysis, 60, 41-45, 2001

24. R.J.M. Westerhof, D.W.F. Brilman, M. Garcia-Perez, Z. Wang, S.R.G. Oudenhoven, W.P.M. van Swaaij, S.R.A. Kersten, Fractional condensation of biomass fast pyrolysis vapor, Energy and Fuels, 25, 1817-1829, 2011 
25. A. Oasmaa, G.V.C. Peacocke, A guide to physical property characterization of biomass derived fast pyrolysis liquids, VTT, Technical Research Centre of Finland, Espoo, 2001

26. E. Hoekstra, S.R.A. Kersten, A. Tudos, D. Meier, J.A. Hogendoorn, Possibilities and pitfalls in analyzing (upgraded) pyrolysis oil by Size Exclusion Chromatography (SEC), J. Anal. Appl. Pyrolysis, 91, 76-88, 2011

27. A.M. Azeez, D. Meier, J. Odermatt, T. Willner, Fast pyrolysis of African and European lignocellulosic biomasses using Py-GC/MS and fluidized bed reactor, Energy and Fuels, 24, 20782085, 2010

28. R. Fahmi, A.V. Bridgwater, I. Donnison, N. Yates, J.M. Stones, The effect of lignin and inorganic species in biomass on pyrolysis oil yields, quality and stability, Fuel, 87, 1230- 1240, 2008

29. A. Jensen, K.D. Johansen, TG-FTIR Study of the influence of potassium chloride on wheat straw pyrolysis, Energy and Fuels, 12, 929-938, 1998

30. R.J.M. Westerhof, N.J.M. Kuipers, S.R.A. Kersten, W.P.M. van Swaaij, Controlling the water content of biomass fast pyrolysis oil, Ind. Chem. Res., 46, 9238-9247, 2007

31. M.J. Antal, Effects of reactor severity on the gas-phase pyrolysis of cellulose- and kraft ligninderived volatile matter, Ind. Eng. Chem. Prod. Res. Dev., 22, 366-375, 1983

32. J.A. Caballero, R. Font, A. Marcilla, Kinetic study of the secondary thermal decomposition of kraft lignin, J. Anal. Appl. Pyrolysis, 38, 131-152, 1996

33. F. Ates, E. Putun, A.E. Putun, Fast pyrolysis of sesame stalk: yields and structural analysis of biooil, J. Anal. Appl. Pyrolysis, 71, 779-790, 2004

34. C. Acikgoz, O. Onay, O.M. Kockar, Pyrolysis Fast pyrolysis of linseed: product yields and compositions, J. Anal. Appl. Pyrolysis, 71, 417-429, 2004

35. W.J. De Sisto, N. Hill, S.H. Beis, S. Mukkamala, J. Joseph, C. Baker, T.H. Ong, E.A. Stemmler, M.C. Wheeler, B.G. Frederick, A. Heiningen, Fast Pyrolysis of pine sawdust in a fluidized-bed reactor, Energy and Fuels, 24, 2642-2651, 2010

36. D. Xianwen, W. Chuangzhi, L. Haibin, C. Yong, The fast pyrolysis of biomass in CFB reactor, Energy and Fuels, 14, 552-557, 2000

37. J.P. Diebold, S. Cernik, Additives to lower and stabilize the viscosity of pyrolysis oils during storage, Energy and Fuels, 11, 1081-1091, 1997

38. P. Nanou, G. van Rossum, W.P.M. van Swaaij, S.R.A. Kersten, Evaluation of catalytic effects in gasification of biomass at intermediate temperature and pressure, Energy and Fuels, 25, 12421253, 2011

39. P.R. Patwardhan, J.A. Satro, R.C. Brown, B.H. Shanks, Influence of inorganic salts on the primary pyrolysis products of cellulose, Bioresour Technol., 101(12), 4646-4655, 2010

40. P.R. Patwardhan, R.C. Brown, B.H. Shanks, Product Distribution from the Fast Pyrolysis of Hemicellulose, ChemSusChem, 4(5), 636-643, 2011

41. A.G. Liden, F. Berruti, D.S. Scott, A kinetic model for the production of liquids from the flash pyrolysis of biomass, Chem. Eng. Comm., 65, 207-221, 1988

42. D.K. Shen, S. Gu, K.H. Luo, S.R. Wang, M.X. Fang, The pyrolytic degradation of wood-derived lignin from pulping process, Bioresour. Technol., 101, 6136-6146, 2010

43. D.K. Shen, S. Gu, The mechanism for thermal decomposition of cellulose and its main products. Bioresour. Technol., 100, 6496-6504, 2009

44. D.K. Shen, S. Gu, A.V. Bridgwater, Study on the pyrolytic behavior of xylan-based hemicellulose using TG-FTIR and Py-GC-FTIR, J. Anal. Appl. Pyrolysis, 87, 199-206, 2010

45. Y.C. Lin, J. Cho, G.A. Tompsett, P.R. Westmoreland, G.W. Huber, Kinetics and mechanism of cellulose pyrolysis, J. Phys. Chem., 113, 20097-20107, 2009

46. A. Oasmaa, E. Kuoppala, Fast pyrolysis of forestry residue. 3 Storage stability of liquid fuel, Energy and Fuels, 17, 1075-1084, 2003

47. B.B. Uzun, A.E. Putun, E. Putun, Composition of products obtained via fast pyrolysis of olive-oil residue: effect of pyrolysis temperature, J. Anal. Appl. Pyrolysis, 79, 147-153, 2007

48. P.R. Patwardhan, J.A. Satrio, R.C. Brown, B.H. Shanks, Product distribution from fast pyrolysis of glucose-based carbohydrates, J. Anal. Appl. Pyrolysis, 86, 323-330, 2009

49. H. Kawamoto, M. Murayama, S. Saka, Pyrolysis behavior of levoglucosan as an intermediate in cellulose pyrolysis: polymerization into polysaccharide as a key reaction to carbonized product formation, J. Wood. Science, 49, 469-473, 2003

50. C. Branca, P. Giudicianni, C. Di Blasi, GC/MS characterization of liquids generated from lowtemperature pyrolysis of wood, Ind. Eng. Chem. Res, 42, 3190-3202, 2003 


\section{Chapter 4}

51. F. Thurner, U. Mann, Kinetic investigation of wood pyrolysis. Ind. Eng. Chem. Process Des. Dev., 20, 482-488, 1981

52. M.C. Samolada, A.Vasalos, A kinetic approach to the flash pyrolysis of biomass in a fluidized bed reactor, Fuel, 70, 883-889, 1991

53. D. Meier, O. Faix, State of the art of applied fast pyrolysis of lignocellulosic materials - a review, Bioresour. Technol, 68, 71-77, 1999 


\section{Chapter 5}

\section{Fast Pyrolysis of Biomass in a Fluidized Bed Reactor: In Situ Filtering of the Vapors}

A system to remove in situ char/ash from hot pyrolysis vapors has been developed and tested at the University of Twente. The system consists of a continuous fluidized bed reactor $(0.7 \mathrm{~kg} / \mathrm{h})$ with immersed filters (wire mesh, pore size $5 \mu \mathrm{m}$ ) for extracting pyrolysis vapors. Integration of the filter system in the fluidized bed should overcome operational problems related to the increase in pressure drop across the filter in time and a decrease in oil yield as typically observed in downstream pyrolysis vapor filtration and lead to process intensification. In this study the effect of in situ hot pyrolysis vapor filtration has been studied with respect to process stability, product yields, and product quality. Oil obtained via a more conventional cyclone system placed in parallel to the filter system served as reference for the quality and yields of the filtered oil. Good process stability concerning temperature and pressure drop across the hot gas vapor filter was achieved during a $2 \mathrm{~h}$ run, even when using a re-used filter. Particles (char/sand) were retained inside the filter pores located at the outside surface of the filter, while the inside of the filter remained clean apart from some deposits formed on the metal wire and small $1 \mu \mathrm{m}$ particles which slipped through the filter. Mass balance closures higher than 94 wt \% were obtained. Comparable yields (cyclone + filtered oil) were obtained as in the experiments carried out with only the cyclones. The filtered oil contained significantly less solids, alkali metals, and ash compared to cyclone oil. For the alkali metals, only a considerable amount of potassium $(K)$ was still present in filtered pyrolysis oil, which most likely entered the filtered oil via the vapor phase. There were no significant differences in the elemental composition of the oil produced via the filter line and cyclone line. The molecular weight of the filtered oil obtained with nondried feed was always marginally lower compared to the cyclone oil. Results of the aging tests show that the reactivity of pyrolysis oil can already originate from the highly reactive components in pyrolysis oil itself and does not need the presence of charlash. To show the intrinsically high reactivity of solids-free pyrolysis oil vapors, an external filter section (1 4 m pore size) was placed additionally and in series with the filter inside the fluidized bed. The results show that char is formed from the reactive pyrolysis vapors. 


\subsection{Introduction}

Fast pyrolysis is a technology for the conversion of bulky solid biomass into a liquid with an energy density of approximately half that of fossil oil ${ }^{1}$. Several feedstocks are suitable for this process; one of them is lignocellulosic biomass which is not competing with the food chain. In fast pyrolysis, organic material is heated rapidly to $450-500{ }^{0} \mathrm{C}$ in the absence of oxygen under atmospheric pressure. A short residence time is required to obtain high oil yields. At these conditions, biomass is converted to vapors, permanent gases, and char. After char separation, the vapors are condensed to a dark brown liquid known as pyrolysis oil ${ }^{2}$. The oil consists of a complex mixture of oxygenated compounds; the major groups of compounds identified are water, hydroxyaldehydes, hydroxyketones, sugars, carboxylic acids, and phenolics ${ }^{3}$. Possible applications for pyrolysis oil include direct combustion ${ }^{4}$, coprocessing in refinery units ${ }^{5}$, gasification eventually followed by Fischer-Tropsch synthesis ${ }^{4}$, hydrogen production ${ }^{6}$, and extraction of chemicals ${ }^{4}$.

In a conventional pyrolysis system some fine char is inevitably entrained. Inorganics (defined as ash) appear to be the center of char formation reactions ${ }^{7,8}$. As ash is mainly incorporated within the char fraction, the entrained solids fraction also contains the ash ${ }^{1,7-}$ 10. The presence of char/ash makes pyrolysis oil unsuitable for direct combustion in conventional oil/gas boilers and turbine operations, because of fouling, corrosion, erosion, and plugging of orifices ${ }^{7-9}$. Furthermore, char/ash is generally believed to contribute to secondary cracking reactions in the vapor phase, thereby lowering the oil yield $^{1,7,11,12}$. Char/ash even seems to catalyze reactions in the liquid phase at ambient conditions $^{1,13,14}$. This instability of pyrolysis oil during storage is known under the name "aging". Aging results in a gradual increase in average molecular weight and water content, thereby also increasing the viscosity ${ }^{10,12,15}$. Finally, a lower ash/char content is expected to have a positive effect with respect to poisoning and deactivation on the catalysts used for upgrading pyrolysis oil (hydrodeoxgynetation, catalytic decarboxylation). Rapid and complete char separation is therefore desirable.

Hot gas vapor filtration appears to be a promising technique to reduce the ash and char content in pyrolysis oils. Using hot gas vapor filtration, char (including ash) is filtered from both the hot vapors and permanent gases prior to condensation. A decrease in ash content ( 20 times) in pyrolysis oil was observed by several researchers ${ }^{7,9,16}$.

The objective of this project is the development of a novel system to remove, in situ, char/minerals from hot pyrolysis vapors. For this, a fluidized bed with immersed filters for extracting pyrolysis vapors is proposed. It is anticipated that, due to the sourcing action of the bed particles, the filters are cleaned continuously preventing an increase in 
pressure drop across the filter as typically observed in external filtering. In this way, reaction and separation are integrated in a single apparatus. This integrated approach will also prevent an increased residence time as observed with external filtering of pyrolysis oil vapors, thereby preventing excessive secondary cracking reactions. The concept of in situ filtering was presented in an earlier article by Wang et $\mathrm{al}^{17}$. The influence of the filter on the hydrodynamics of the fluidized bed is presented in his $\mathrm{PhD}$ thesis ${ }^{25}$. In this chapter, experimental results will be presented obtained under real process conditions. Tests were carried out in two different setups: (1) a small batchwise setup (20 g per batch); (2) a continuous bench scale plant $(0.70 \mathrm{~kg} / \mathrm{h})$. Using the bench scale plant, the influence of the filters on the operability of the process, the composition of the oil, and char formation reactions in the vapor phase have been studied.

\subsection{Review of downstream hot gas vapor filtration techniques}

This section presents a brief review of the literature on hot gas vapor filtration. All research so far has focused on filtering of vapors after the reactor. The articles are mostly about the comparison of hot gas filtered oil compared to a system using cyclones. Of course, a lot of processes are available without using a cyclone or a filter (for example, the rotating cone reactor as developed by BTG). A summary of the results obtained using external hot gas vapor filtration is listed in Table 5.1. In these studies, various reactors and filters have been used. Most studies were carried out in a fluidized bed reactor (Aston

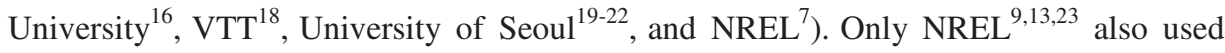
another type of reactor: the so-called vortex reactor with a hot gas vapor filtration unit included. Filters used include cylindrical 316 stainless steel filter (pore size $2 \mu \mathrm{m}$ ) ${ }^{7}$, rigid Inconel filters ${ }^{9,16}$, flexible ceramic cloths (pore size $\left.2 \mu \mathrm{m}\right)^{9,13,23}$, Tenmat Firefly filters ${ }^{16}$, and Bekipor sintered stainless steel ${ }^{18}$.

The data in Table 5.1 show that passing hot vapors through a filter typically produced an oil with at least 20 times less ash and severalfold lower alkali metal contents than when a cyclone separator was used $^{7,9,16}$. Pyrolysis oil with only $10 \mathrm{ppm}$ alkali metals ${ }^{20,21}$ and an ash content lower than $0.05 \mathrm{wt} \%^{7}$ has already been produced. The concentration of ash in the biomass feedstocks as used in the hot gas vapor filtration experiments (Table 5.1) ranged from less than $1 \mathrm{wt} \%$ for softwoods to almost $10 \mathrm{wt} \%$ for rice straw and bamboo. At the University of Seoul ${ }^{19-22}$, relatively high levels of alkali metals were recovered in the pyrolysis oil when ash rich feedstocks were used. However, for the experiments carried out at NREL ${ }^{9,13,23}$ this phenomenon was not observed. 
Fast Pyrolysis of Biomass in a Fluidized Bed Reactor: In Situ Filtering of the Vapors

Table 5.1 Literature results hot gas vapor filtration

\begin{tabular}{|c|c|c|c|c|c|c|c|c|c|c|c|c|c|c|c|c|c|c|c|c|c|c|c|c|c|c|c|}
\hline \multirow{3}{*}{ 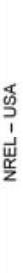 } & \multirow{3}{*}{ 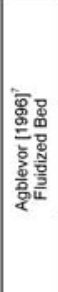 } & "s & & & & & & & 웅 & & $\frac{8}{0}$ & $\frac{0}{\square}$ & 의 & $\stackrel{N}{=}$ & - & & - & & & & & & 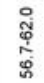 & & - & & 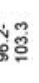 \\
\hline & & 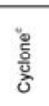 & & & & & & & f & & 兽 & ஃ & $\stackrel{\oplus}{m}$ & $\infty$ & ్ & & $\infty$ & & & & & & 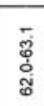 & & & . & 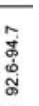 \\
\hline & & 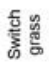 & 웅 & $\frac{m}{9}$ & 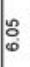 & 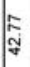 & 禺 & & $\underset{\leftarrow}{\stackrel{乛}{+}}$ & & 啇 & 을 & 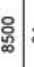 & $\bar{m}$ & 足 & 임 & & & & & & & & & & & \\
\hline \multirow{10}{*}{ 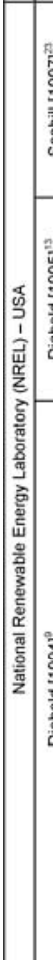 } & \multirow{2}{*}{ 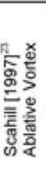 } & 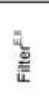 & & $\begin{array}{l}\bar{\phi} \\
\vdots \\
\vdots \\
0 \\
\text { gे }\end{array}$ & 密 & 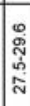 & 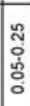 & કેં & & & $\overline{\bar{m}}$ & $\stackrel{\varphi}{-}$ & $\stackrel{?}{2}$ & 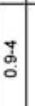 & & & & 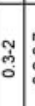 & : & 훙ㅎํ. & $\begin{array}{l}\text { Na } \\
0 \\
\vdots \\
0 \\
0\end{array}$ & 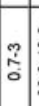 & 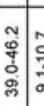 & & 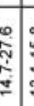 & 我 & 怘 \\
\hline & & 尊 & - & 宊 & $\stackrel{\circ}{\circ}$ & $\bar{y}$ & '́ & & & & & & & & & & & & & & & & & & & & \\
\hline & \multirow{2}{*}{ 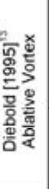 } & 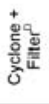 & & $\stackrel{m}{\tilde{\omega}}$ & $\begin{array}{l}n \\
0 \\
0\end{array}$ & 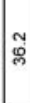 & $\frac{\infty}{0}$ & & & & $\stackrel{\oplus}{\sim}$ & $\underset{\mathcal{N}}{\tilde{y}}$ & 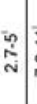 & $\begin{array}{l}\bar{c} \\
\dot{\alpha} \\
\end{array}$ & & ઠ్రి & & $\stackrel{0}{\sim}$ & $\begin{array}{l}\tilde{y} \\
\text { ô } \\
\text { v }\end{array}$ & סू & $\begin{array}{l}0 \\
: \\
0 \\
0\end{array}$ & & 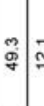 & & $\stackrel{N}{N}$ & ్ָ & $\stackrel{\infty}{\bar{\sigma}}$ \\
\hline & & 흥 융 & 。 & 웋 & : & $\bar{j}$ & $\overline{0}$ & & & & & 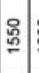 & §్ & $\hat{N}$ & & & & & & & & & & & & & \\
\hline & \multirow{6}{*}{ 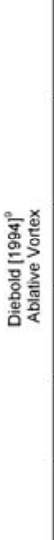 } & 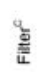 & & & & & & & 。ั & & & ஜ & : & ఫ్ & & & & & & & & & 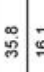 & & & 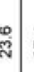 & ষ্心 \\
\hline & & 商 & 0 & & & & & & $\stackrel{8}{-}$ & & & ర్టి & : & 요 & & & & & & & & & & & & & \\
\hline & & 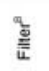 & & & & & & & 훙 & & & 今े & $\stackrel{\circ}{\frac{n}{2}}$ & ర్ & & & & & & & & & 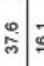 & & $\frac{\infty}{\sim}$ & 幽 & ஜ̈ \\
\hline & & 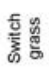 & 0 & & & & & & $\stackrel{\varnothing}{\circ}$ & & & 迎 & : & $R$ & & & & & & & & & & & & & \\
\hline & & 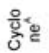 & & & & & & & \%ू & & & 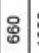 & 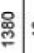 & $q$ & & & & & & & & & 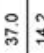 & $\underset{\square}{ \pm}$ & $\Phi$ & : & $\widehat{\tilde{\delta}}$ \\
\hline & & 总管 & 0 & & & & & & 0 & & & 。్లి & ర్రి| & से & & & & & & & & & & & & & \\
\hline & & & 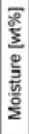 & 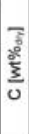 & $\begin{array}{l}\frac{7}{5} \\
\frac{8}{8} \\
\frac{8}{5} \\
\frac{5}{1}\end{array}$ & $\frac{6}{0}$ & $\frac{7}{z}$ & $\frac{\xi}{\infty}$ & $\frac{\sqrt{\frac{9}{5}}}{\frac{5}{4}}$ & 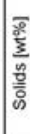 & $\begin{array}{l}\bar{g} \\
\overline{\frac{a}{0}} \\
\overline{\bar{v}}\end{array}$ & $\begin{array}{l}\bar{E} \\
\frac{0}{0} \\
\overline{0} \\
0\end{array}$ & $\begin{array}{l}\bar{E} \\
\frac{\overline{0}}{a} \\
\bar{x}\end{array}$ & $\begin{array}{l}\overline{\bar{\varepsilon}} \\
\frac{\mathrm{c}}{0} \\
\overline{\mathrm{z}}\end{array}$ & 宮 & $\begin{array}{l}\bar{E} \\
\text { 흥 }\end{array}$ & 䯧 & $\begin{array}{l}\overline{\frac{\sigma}{a}} \\
\frac{\mathrm{a}}{\bar{\alpha}}\end{array}$ & 㤩 & $\frac{\overline{\mathrm{g}}}{\overline{\mathrm{c}}}$ & $\begin{array}{l}\bar{E} \\
\frac{\overline{0}}{\mathrm{a}} \\
\bar{\Sigma}\end{array}$ & $\begin{array}{l}\bar{E} \\
\frac{\bar{a}}{a} \\
\frac{0}{\Sigma}\end{array}$ & 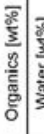 & $\frac{5}{\frac{8}{5}}$ & 产 & 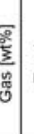 & 要 \\
\hline
\end{tabular}

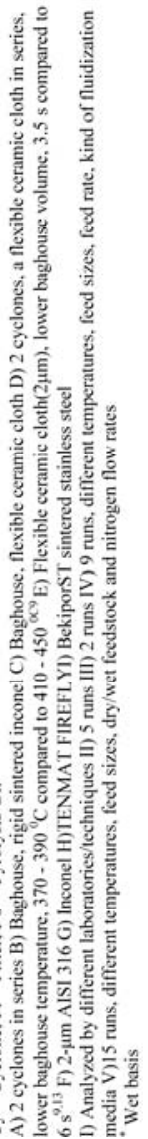


Chapter 5

Table 5.1 (continued) Literature results hot gas vapor filtration

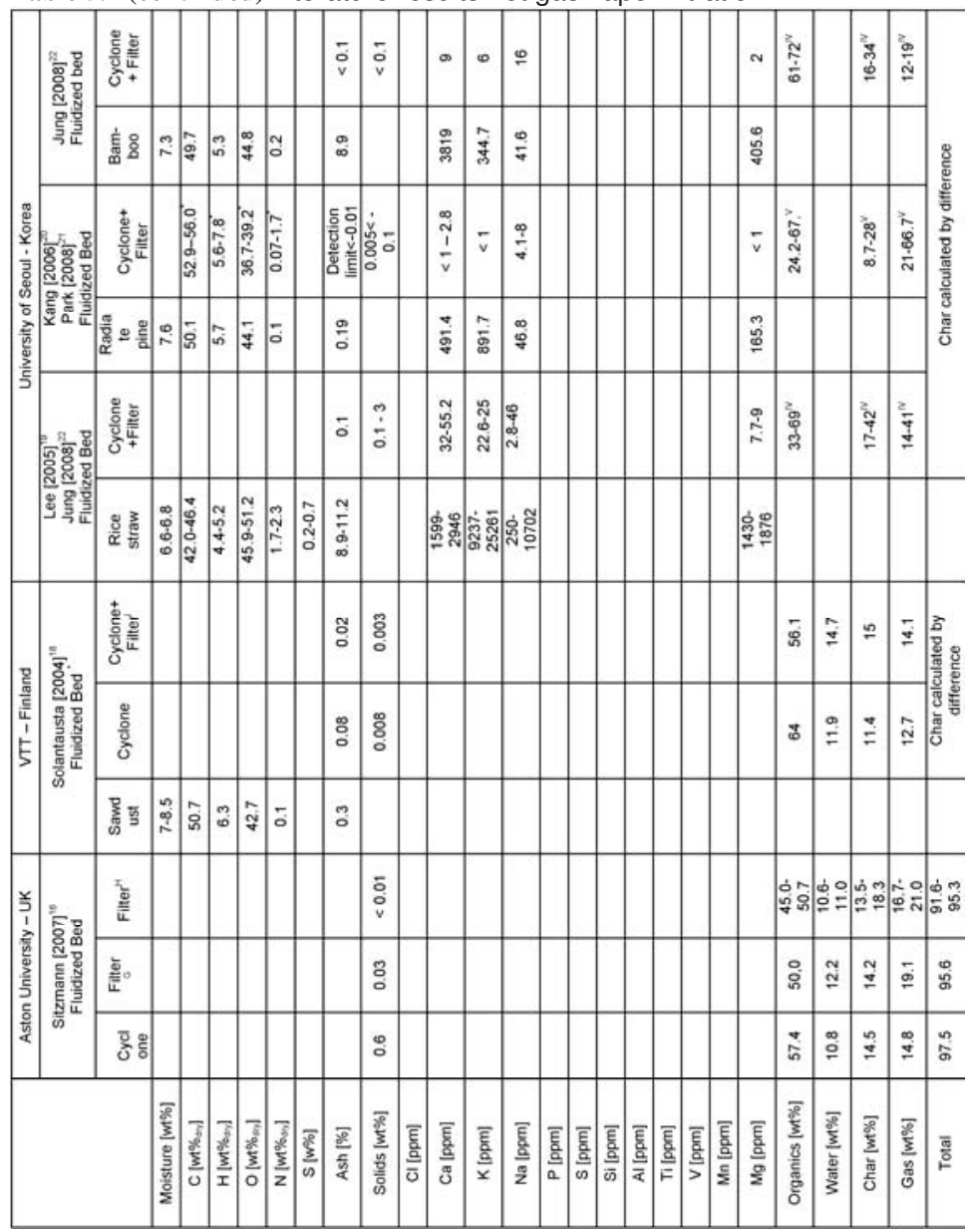

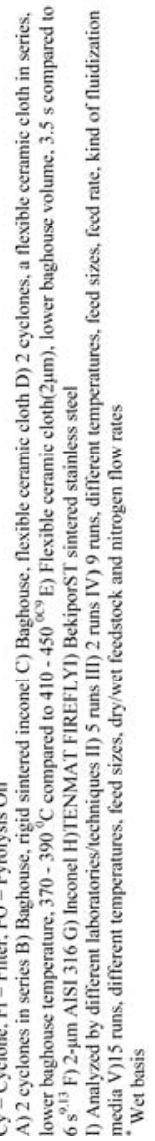


Only limited results are available concerning the composition of the produced filtered oil compared to cyclone-separated oil. Based on a solvent fractionation scheme, Solantausta et $\mathrm{al}^{18}$ observed no significant changes in chemical composition of the nonfiltered and filtered oils. However, they observed an almost linear increase in moisture content during a $5 \mathrm{~h}$ run ( $2 \mathrm{wt} \%$ increase in water content during the run). Shihadeh ${ }^{24}$ and Oasmaa and Czernik $^{10}$ reported a size reduction of oligomeric chains in filtered oils which results in a lower average molecular weight and a lower oil viscosity. They explained this effect by the additional residence time of the extra filter stage at elevated temperature which results in more severe cracking of the pyrolysis vapors. However, the oils that were compared were produced by two completely different processes: NREL (ablative vortex reactor) and Ensyn (rapid thermal process) ${ }^{24}$, which could be responsible for the observed differences as well.

The instability of oil during storage for hot gas filtered oil has been investigated by Solantausta et al. ${ }^{18}$ and Wang ${ }^{25}$. Solantausta et al. ${ }^{18}$ carried out an accelerated aging test of filtered and nonfiltered oils at $80{ }^{\circ} \mathrm{C}$ for $24 \mathrm{~h}$, which resembles 1 year of storage at room temperature ${ }^{28}$. The quality of the products was assessed by their in-house-developed VTT fractionation scheme. They did not observe any improvement in the oil quality for the hot gas filtered oil. However, Wang ${ }^{25}$ observed a lower aging rate of the filtered oil by comparing the increase in viscosity over time at both room temperature and $90{ }^{\circ} \mathrm{C}$ (Figure 5.1). As can be seen in Figure 5.1 the aging rate seems to increase exponentially with ash content. Although literature results about the downstream hot gas vapor filtration techniques seem to be very promising, these technologies have two main disadvantages: (1) a continuous increase in pressure drop in operation and (2) a lower pyrolysis yield.

\section{Continuous increase in pressure drop during operation}

A disadvantage of external filtering is the limited ability to control or limit the increase in pressure drop across the filter during operation. During filtration the deposition of solids increases the cake height and clogs the filter pores, which is accompanied by an increase in total cake resistance. Several ideas have already been tried out to overcome this problem, which basically can be classified into three groups:

1. Difficult and expensive back-flushing systems have been used ${ }^{9,13,16,18,23}$, but none of them was able to recover the initial pressure drop across the filter regardless of the temperature or back-pulse pressure and duration ${ }^{23}$.

2. Different filter materials have been tested. Diebold et al. ${ }^{9}$ studied both a flexible ceramic filter cloth and a rigid sintered Inconel filter. The flexible filters were easier to clean, because these filters were able to expand and break the filter cake much better. Nevertheless, an increase in pressure drop could not be prevented ${ }^{23}$. 
3. Various configurations have been tried. Some researchers have placed the filter after a cyclone ${ }^{13,18-22}$, while others used a filter section without prior solids removal ${ }^{7,9.16,23}$. The idea of the first configuration is to pre-separate the coarser particles so that only very fine char has to be removed by the filter. Only the vortex reactor at NREL was operated with both configurations. The researchers at NREL observed a denser cake layer on the filter (that appeared to have sintered) for the configuration including the cyclone ${ }^{13}$ than for the configuration in which only the filter was used ${ }^{9,23}$.

In conclusion, none of the researchers, to the best of our knowledge, could limit the increase in pressure drop across the filter properly during long-term operation.

\section{Lower pyrolysis oil yield}

Using an external hot filter to separate the char/ash particles from the pyrolysis vapors results in lower oil yields: the yields typically decrease by $5-10 \mathrm{wt} \%^{7,16,18}$. Various mechanisms might explain this phenomenon:

1. An extension of the vapor residence at high temperatures as encountered during external vapor filtrations typically results in increased cracking severity ${ }^{9,13,23}$. To minimize this, the temperature is to be minimized, meaning that the filter system needs to be operated as close as possible to the condensation temperature, although this entails some risk of plugging. At the same time the residence time of the vapors at high temperature needs to be minimized as well. Experiments carried out in the vortex reactor at NREL (Table 5.1) clearly show an increase in oil yield while reducing the filter baghouse temperature ${ }^{13}$ and filter baghouse volume $^{23}$.

2. Char deposited onto the filter may catalyze the cracking of the pyrolysis vapors, thereby lowering the oil yield ${ }^{7,11}$.

From the results obtained in the literature on external vapor filtration, it may be concluded that vapor filtration is very efficient to reduce the char and ash content of pyrolysis oil, but is still plagued by operational problems (increase in pressure drop across the filter) and relatively low pyrolysis oil yields. The use of in situ vapor filtration might be a new and efficient way to circumvent these drawbacks. 


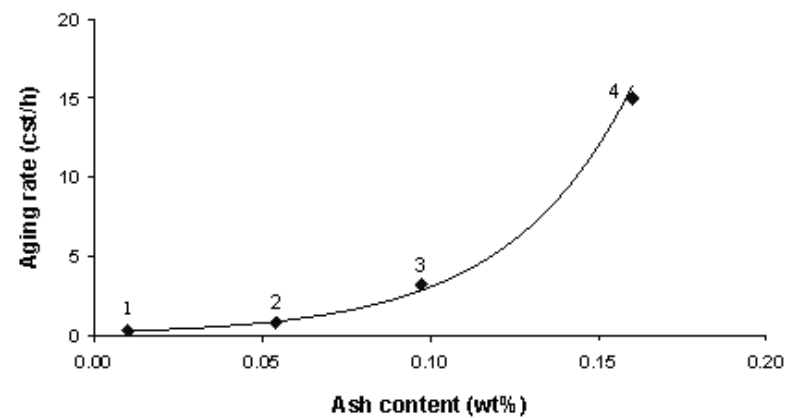

Figure 5.1 Aging rate at $90{ }^{\circ} \mathrm{C}$ according to Wang et al. ${ }^{0} 1$ ) UT (Lignocel 9), filtered 2) UT (lignocel 9), non-filtered 3) BTG (beech), non-filtered 4) BTG (pine), non-filtered

\subsection{Experimental setup and materials}

\subsubsection{Feedstock Materials}

Two types of biomass have been used. Beech wood cylinders with a length of $6 \mathrm{~mm}$ and a diameter of $3 \mathrm{~mm}$ were used for the batch experiments, and Lignocel $9\left(d_{\mathrm{p}}<1 \mathrm{~mm}\right)$ was used for the experiments carried out in the continuous pilot plant. The chemical composition, elemental composition, ash content, alkali/alkaline earth content, and moisture content of both feedstocks are listed in Table 5.2; the accompanying analytical techniques are described in section 5.3.4.

Table 5.2 Properties of feedstock materials on dry basis

\begin{tabular}{|c|c|c|c|c|c|c|c|c|c|}
\hline \multirow{3}{*}{$\begin{array}{l}\text { Beech wood } \\
\text { (hard wood) }\end{array}$} & \multicolumn{2}{|c|}{ Cellulose } & \multicolumn{2}{|c|}{ Hemicellulose } & \multicolumn{2}{|c|}{ Lignin } & \multicolumn{2}{|c|}{ Moisture $^{\mathrm{e}}$} & Ash \\
\hline & \multicolumn{6}{|c|}{$\left[\mathrm{wt} \%_{\mathrm{dry}}\right]$} & \multicolumn{3}{|c|}{ [wt\%] } \\
\hline & \multicolumn{2}{|c|}{$34^{\mathrm{a}}$} & \multicolumn{2}{|c|}{$22^{\mathrm{a}}$} & \multicolumn{2}{|c|}{$31^{\mathrm{a}}$} & \multicolumn{2}{|c|}{$2.20^{\mathrm{a}}$} & N.A. \\
\hline $\begin{array}{l}\text { Lignocel } 9 \\
\text { (pine soft wood) }\end{array}$ & \multicolumn{2}{|c|}{$35^{\mathrm{a}}$} & \multicolumn{2}{|c|}{$29^{\mathrm{a}}$} & \multicolumn{2}{|c|}{$28^{\mathrm{a}}$} & \multicolumn{2}{|c|}{$0.6^{\mathrm{c}}$} & $8.2^{\mathrm{c}}$ \\
\hline & \multicolumn{2}{|c|}{$\mathrm{C}$} & \multicolumn{2}{|c|}{$\mathrm{H}$} & \multicolumn{2}{|c|}{$\mathrm{O}$} & \multicolumn{2}{|c|}{$\mathrm{N}$} & S \\
\hline & \multicolumn{9}{|c|}{$\left[\mathrm{wt} \%_{\mathrm{dry}}\right]$} \\
\hline $\begin{array}{l}\text { Beech wood } \\
\text { (hard wood) }\end{array}$ & \multicolumn{2}{|c|}{$44.5^{\mathrm{a}}$} & \multicolumn{2}{|c|}{$5.9^{\mathrm{a}}$} & \multicolumn{2}{|c|}{$49.3^{\mathrm{a}}$} & \multicolumn{2}{|c|}{$0.3^{\mathrm{a}}$} & $0.1^{\mathrm{a}}$ \\
\hline $\begin{array}{l}\text { Lignocel } 9 \\
\text { (pine soft wood) }\end{array}$ & \multicolumn{2}{|c|}{$47.6^{\mathrm{c}}$} & \multicolumn{2}{|c|}{$5.9^{\mathrm{c}}$} & \multicolumn{2}{|c|}{$46.3^{\mathrm{c}}$} & \multicolumn{2}{|c|}{$0.2^{\mathrm{c}}$} & N.A. \\
\hline & $\mathrm{K}$ & $\mathrm{Mg}$ & $\mathrm{Ca}$ & $\mathrm{Al}$ & $\mathrm{Ba}$ & $\mathrm{Fe}$ & Mn & $\mathrm{Sr}$ & $\mathrm{Zn}$ \\
\hline & \multicolumn{9}{|c|}{$[\mathrm{ppm}]$} \\
\hline $\begin{array}{l}\text { Beech wood } \\
\text { (hard wood) }\end{array}$ & $164^{\mathrm{a}}$ & $540^{\mathrm{a}}$ & $6600^{\mathrm{a}}$ & & & & & & \\
\hline $\begin{array}{l}\text { Lignocel } 9 \\
\text { (pine soft wood) }\end{array}$ & $400^{\mathrm{b}}$ & $172^{\mathrm{b}}$ & $980^{\mathrm{b}}$ & $2^{b}$ & $18^{\mathrm{b}}$ & $64^{\mathrm{b}}$ & $172^{\mathrm{b}}$ & $5^{\mathrm{b}}$ & $11^{\mathrm{b}}$ \\
\hline
\end{tabular}




\subsubsection{Batch Laboratory Scale Fluidized Bed}

Prior to the continuous in situ filtering of the pyrolysis vapors, a series of preliminary tests was carried out in a batch laboratory fluidized bed. The scheme of the setup is shown in Figure 5.2.

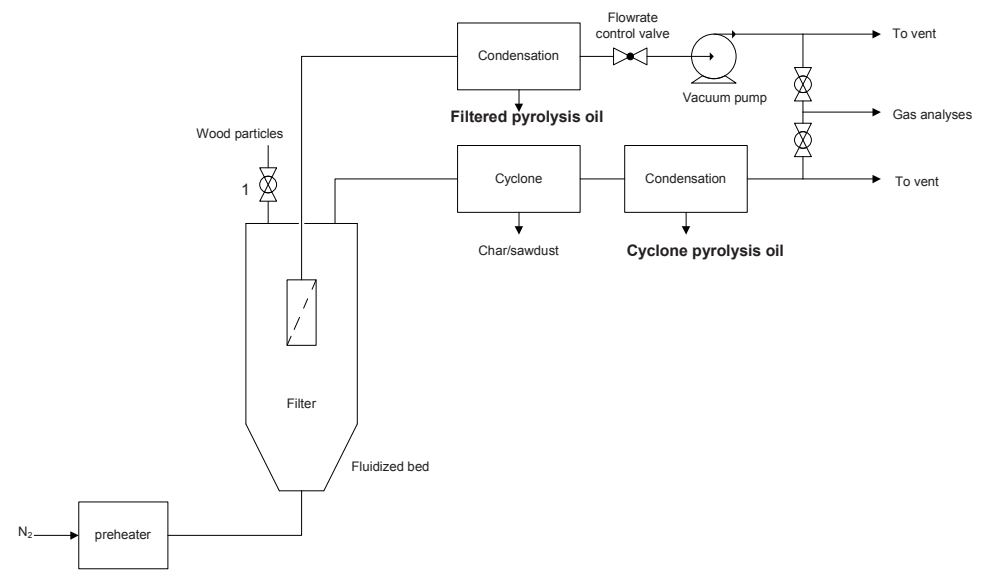

Figure 5.2 Flowsheet of the batch laboratory scale set-up

These preliminary experiments were performed batchwise. Per experiment about $20 \mathrm{~g}$ of beech wood cylinders was introduced into the reactor. The beech wood particles were added to the fluidized bed by opening valve 1 (see Figure 5.2). The fluidized bed reactor (inner diameter $=60 \mathrm{~mm}$ ) was made from stainless steel and heated by an electrical oven. During an experiment, the produced vapors were extracted from the reactor through a single immersed filter and via a cyclone. Cylindrical filters with pore sizes of 10-15 $\mu \mathrm{m}$ (ceramic) and $6 \mu \mathrm{m}$ (metal) were used (length, $30 \mathrm{~mm}$; diameter, $15 \mathrm{~mm}$ ). Both the pyrolysis vapors extracted via the filter line and those extracted via the cyclone line were led to two identical condensation trains from where the produced vapors were collected. By adjustment of the vacuum pump, nearly equal amounts of filtered and nonfiltered oil samples could be obtained. A typical experiment lasted ca. 2 min. A more detailed description of the batch laboratory scale fluidized bed has been published elsewhere ${ }^{26}$.

\subsubsection{Continuous pilot plant}

The bench scale continuous pilot plant as originally developed by Westerhof et al. ${ }^{27}$ was redesigned in order to study the performance of the filter-assisted fluidized bed reactor under typical pyrolysis conditions. The most important changes with respect to the original design as described by Westerhof et al. include (1) independently controlled ovens for reactor and char separation and (2) a filter placed inside the fluidized bed. An overview of the setup is shown in Figure 5.3, and the operational conditions are reported in Table 5.3. Information about the feeding, cyclone, and condensation section can be found in the article of Westerhof et al. ${ }^{27}$ 


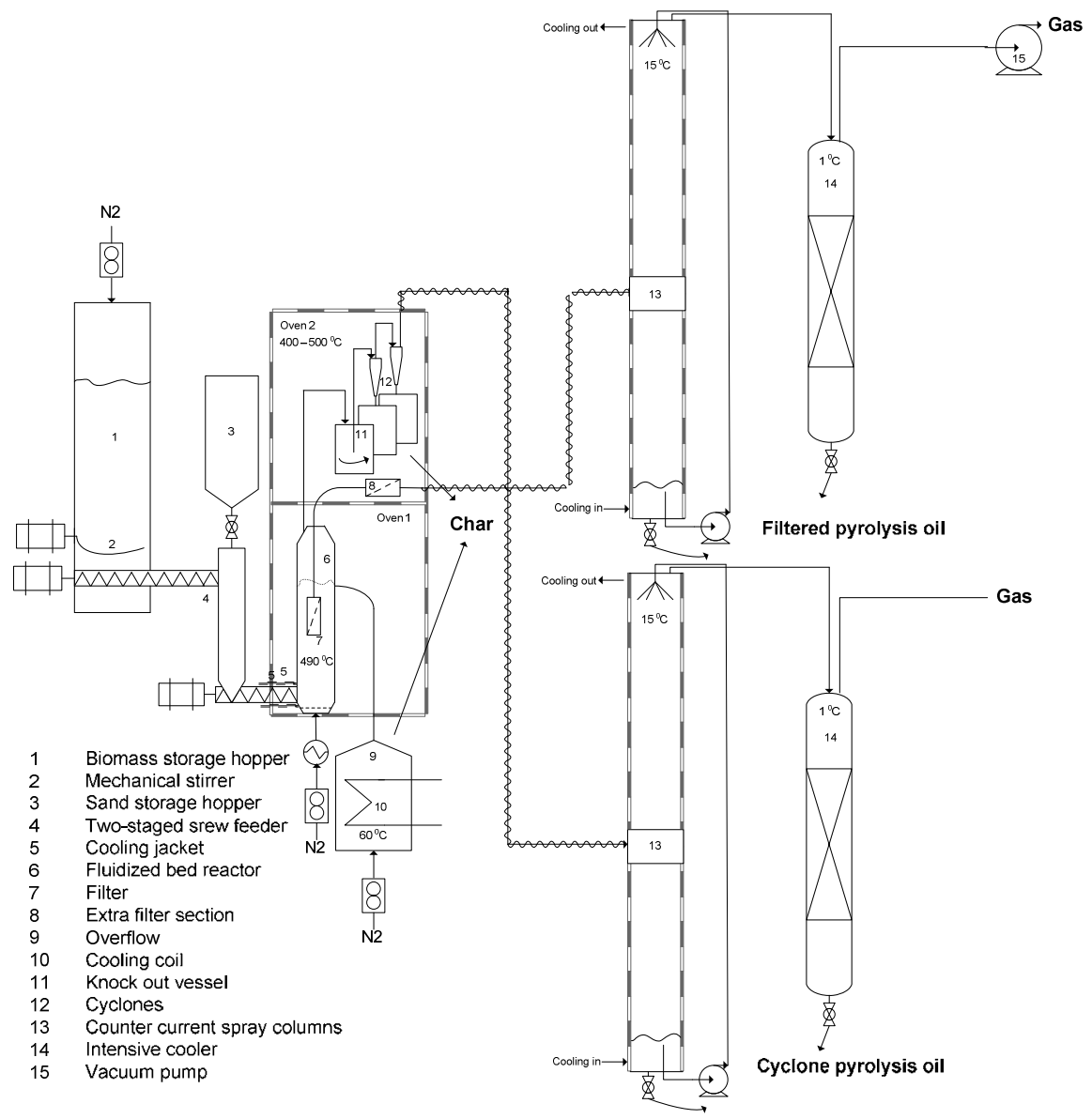

Figure 5.3 Scheme pyrolysis plant

Table 5.3 Operating conditions pyrolysis plant

\begin{tabular}{|l|l|l|}
\hline Experimental time & $120-170$ & Minutes \\
\hline$\Phi_{\mathrm{m} \text { biomass }}$ & $0.63-0.76$ & $\mathrm{~kg} / \mathrm{hr}$ \\
\hline $\mathrm{M}_{\text {sand, initial }}$ & 2.0 & $\mathrm{~kg}$ \\
\hline Char hold-up & $0.15-0.20$ & $\mathrm{~m}^{3}$ of char $/ \mathrm{m}^{3}$ of sand \\
\hline $\mathrm{v}_{\text {vapors+N2 }}$ through filter & 0.05 & $\mathrm{~m} / \mathrm{s}$ \\
\hline$\tau_{\text {reactor }- \text { filter line (hot) }}{ }^{\mathrm{a}}$ & \pm 0.8 & $\mathrm{~s}$ \\
\hline$\tau_{\text {reactor }- \text { cyclone line (hot) }}{ }^{\mathrm{a}}$ & \pm 2.5 & $\mathrm{~s}$ \\
\hline $\mathrm{T}_{\text {condensor }}$ & 15 & ${ }^{0} \mathrm{C}$ \\
\hline $\mathrm{T}_{\text {intensive cooler }}$ & 1 & ${ }^{0} \mathrm{C}$ \\
${ }^{\mathrm{a}}$ for $\Phi_{\mathrm{v}, \text { filter }} / \Phi_{\mathrm{v}, \text { cyclone }}=1$ & \multicolumn{2}{|l}{} \\
\end{tabular}


A detailed overview of the fluidized bed reactor is shown in Figure 5.4. The reactor (Figure 5.3,6) was made from stainless steel 316, with a main diameter of $100 \mathrm{~mm}$ and a total height of $400 \mathrm{~mm}$. The fluidized bed was heated with an electrical oven to $\pm 490{ }^{\circ} \mathrm{C}$ (oven 1). The reported reactor temperature was measured inside the filter. The sand/char mixture on top of the bed was removed by a solids overflow tube into a collection vessel (9). Preheated fluidization gas $\left(\mathrm{N}_{2}\right)$ was fed through a metal sintered plate. A typical ratio of the cyclone line flow to the filter line flow of 1-1.5 was used $\left(v_{\text {vapors }+\mathrm{N} 2}\right.$ through filter $\sim 0.05 \mathrm{~m} / \mathrm{s}$ ). This ratio was set at the beginning of every run by adjustment of a valve regulating the vacuum strength. Cold flow experiments at room temperature at ambient pressure have been carried out to determine the required nitrogen flow rate for proper fluidization. The nitrogen superficial velocity was set to $0.058 \mathrm{~m} / \mathrm{s}$, corresponding to 0.15 $\mathrm{m} / \mathrm{s}$ under reaction conditions. During a run the pressures drop across the bed and therewith the fluidization behaviour was continuously monitored by using a simple Utube manometer. No problems concerning the fluidization behavior were observed.

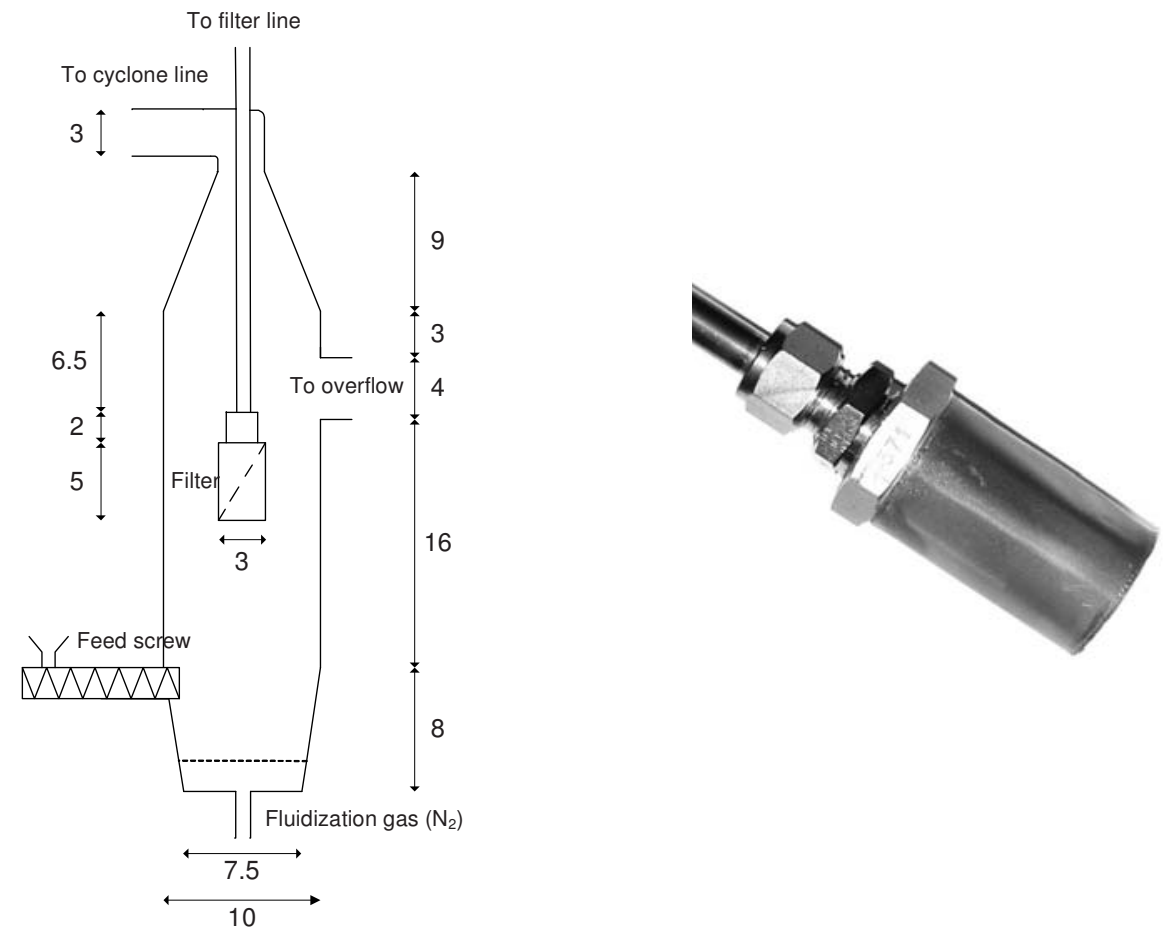

Figure 5.4 Reactor continuous bench scale setup, dimensions in cm (left). Filter (right) 
A custom-made cylindrically shaped filter (diameter $3 \mathrm{~cm}$, height $5 \mathrm{~cm}$ ) made of wire mesh (Dinxperlo, Wire Weaving Co. Ltd., AISI 316, mesh $400 \times 2800$, wire thickness $0.030 \times 0.022 \mathrm{~mm}$, Dutch Weave) with an absolute retention of $4-5 \mu \mathrm{m}$ was used (Figure 5.4). The filter was placed vertically inside the fluidized bed reactor. Preliminary experiments with horizontally placed filters resulted in nonuniform fluidization behavior. ${ }^{25}$ Besides the orientation, the vertical position of the filter inside the reactor has proven to be important as well: Wang et al. ${ }^{25}$ showed that the thickness of the filter cake decreased when the filter was placed at a higher position in the bed. This is probably caused by the bubble diameter which increases with the height in the bed and therewith increases the turbulent force ${ }^{25}$. For this reason the filter was placed as high as possible inside the fluidized bed reactor, with the top of the filter placed just below the level of the bed surface (see Figure 5.4). The pressure drop across the filter was monitored using two pressure sensors (Gems, 2200 series). An important improvement compared to the downstream hot gas vapor filtration techniques as discussed in section 5.2 is the short residence time of the vapors (during these experiments, typically $\sim 0.8 \mathrm{~s}$ ). The residence was roughly 3 times shorter than the one in the cyclone line ( $2.5 \mathrm{~s}$, see Table 5.3$)$.

Two identical condensation sections have been used for the filter and cyclone line, respectively. The total flow of remaining permanent gases including the inert fluidization gas (nitrogen) was measured using a dry gas flow meter (ACTARIS G6 RF1), and its composition was determined by using a gas chromatograph (Micro GC Varian CP 4900). The following two definitions for the two different types of produced oil will be used from here on: (1) filtered oil, pyrolysis oil formed after condensation of the vapors obtained through the filter(s); (2) cyclone oil, pyrolysis oil formed after condensation of the vapors extracted via the knockout vessel and both cyclones.

\subsubsection{Analyses}

Yields of the solid and liquid products were determined by weighing these fractions. The gas amount was determined by multiplying the gas flow rate with the composition. Detailed calculation procedures and the reliability of this method are described by Westerhof et $\mathrm{al}^{27}$.

The composition of the produced gases, char, and pyrolysis oils has been determined by various techniques: elemental analysis (Fisons Instruments 1108 CHNS-O), water content (Karl Fischer titration, Metrohm 787 KFTitrino), solids ${ }^{28}$ (char and traces of some possibly entrained sand) content (gravimetric), ash content (NPR-CEN/TS $15403-550{ }^{\circ} \mathrm{C}$ for biomass, NEN-EN-ISO $6245-775{ }^{\circ} \mathrm{C}$ for pyrolysis oil), molecular weight distribution (GPC, Agilent Technologies 1200 series, RID detector, eluent $1 \mathrm{~mL} / \mathrm{min}$ THF, solvent 10 $\mathrm{mg}$ of pyrolysis oil/mL of THF, columns 3 PLgel3 $\mu \mathrm{m}$ MIXED-E placed in series, standard 162-30 $000 \mathrm{~g} / \mathrm{mol}$ polystyrene), and stability tests ${ }^{28}$ (aging of sample for $24 \mathrm{~h}$ at 
$80{ }^{0} \mathrm{C}$ ). The alkali/alkaline earth metal content was measured by vTI (Germany) using inductively coupled plasma atomic absorption spectroscopy (ICP-AAS).

The filters were analyzed in more detail after the experiment to observe and identify possible blockage. For this scanning electron microscopic (SEM) pictures were made (MESA +, University of Twente) and X-ray diffraction (XRD) analyses were carried out (University of Utrecht, Inorganic Chemistry and Catalysis).

\subsection{Results: batch laboratory scale fluidized bed}

For the preliminary batch laboratory scale experiments, the focus was on the comparison between filtered and nonfiltered oils with respect to total solids and alkali metal contents. In this series a total of four experiments were carried out.

Table 5.4 shows a comparison between the solids contents of filtered oil and nonfiltered oil. When feeding rather large beech wood particles ( $3 \mathrm{~mm}$ diameter and $6 \mathrm{~mm}$ long), the nonfiltered oil contained about $0.1 \mathrm{wt} \%$ solids (Table 5.4, experiments 1 and 2). This is in agreement with results reported in the literature ${ }^{29,30}$. In the filtered oil no solids could be detected by gravimetric methods (detection limit $=10^{-4} \mathrm{wt} \%$; see Table 5.4, experiments 1 and 2). With respect to the alkali/alkaline earth metal content, the filtered oil contains much less potassium and even no magnesium and sodium metal salts. The remaining potassium in filtered oil cannot originate from char because the filtered oils were (almost) free of char (solids). It must consequently be assumed that potassium entered the filtered oil via the vapor phase.

To mimic the conditions of a continuous pyrolysis reactor, about $20 \mathrm{vol} \%$ char was added to the fluidized bed in experiments 3 and 4 . With the additional char in the reactor, the nonfiltered oil contained much more solids than the oil obtained in the experiments without initial char present (Table 5.4, experiments 3 and 4 versus experiments 1 and 2). However, also in this case the filtered oil remained completely solids free.

The nonfiltered oils obtained in experiments 1 and 2 contained concentrations of $\mathrm{Na}, \mathrm{Mg}$, and $\mathrm{K}$ typically observed in pyrolysis oil. The beech wood particles used in experiments 3 and 4 were additionally impregnated with $\mathrm{NaCl}, \mathrm{KCl}$, and $\mathrm{MgCl}_{2}$ solutions. As a result, the produced nonfiltered oils contained more of these alkali metals (experiments 3 and 4 versus experiments 1 and 2). However, also in this case the filtered oils did not contain any $\mathrm{Na}$ and $\mathrm{Mg}$, but somewhat more $\mathrm{K}$ could be detected than in experiments 1 and 2 . The results of the preliminary experiments indicate that particle-free pyrolysis oil with low alkali/alkaline earth content can be produced in a filter-assisted fluidized bed reactor. 
Table 5.4 Solids and alkali content of filtered and non-filtered oils

\begin{tabular}{|c|c|c|c|c|c|c|c|c|}
\hline Exp. & Feed & $\begin{array}{c}\mathrm{U}_{\mathrm{g}} / \mathrm{U}_{\mathrm{mf}} \\
{[-]}\end{array}$ & \multicolumn{2}{|c|}{$\begin{array}{l}\text { Filter pore size } \\
\qquad(\mu \mathrm{m})\end{array}$} & $\begin{array}{l}\text { Solids content } \\
\text { (wt \%) }\end{array}$ & $\begin{array}{c}\mathrm{Na} \\
(\mathrm{ppm})\end{array}$ & $\begin{array}{c}\mathrm{Mg} \\
(\mathrm{ppm})\end{array}$ & $\begin{array}{c}\mathrm{K} \\
(\mathrm{ppm})\end{array}$ \\
\hline \multirow{2}{*}{1} & \multirow{2}{*}{ Beech } & \multirow{2}{*}{4} & Filtered & $10-15$ & $<10^{-4}$ & 0 & 0 & 5.7 \\
\hline & & & Non-filtered & & 0.11 & 3.1 & 7.4 & 34.6 \\
\hline \multirow{2}{*}{2} & \multirow{2}{*}{ Beech } & \multirow{2}{*}{4} & Filtered & 6 & $<10^{-4}$ & 0 & 0 & 5.5 \\
\hline & & & Non-filtered & & 0.07 & 0 & 0.3 & 9.4 \\
\hline \multirow{2}{*}{3} & \multirow{2}{*}{$\begin{array}{l}\text { Beech and } \\
\text { Char }^{\mathrm{b}}\end{array}$} & \multirow{2}{*}{6} & Filtered & 6 & $<10^{-4}$ & 0 & 0 & 14.43 \\
\hline & & & Non-filtered & & $>1$ & 25.8 & 20.9 & 66.46 \\
\hline \multirow[b]{2}{*}{4} & \multirow{2}{*}{$\begin{array}{l}\text { Beech and } \\
\text { Char }\end{array}$} & \multirow{2}{*}{10} & Filtered & 6 & $<10^{-4}$ & 0 & 0 & 7.9 \\
\hline & & & Non-filtered & & $>1$ & 20.0 & 21.5 & 123.9 \\
\hline
\end{tabular}

analysis by BFH, Germany; n.d.: not determined.

${ }^{\mathrm{b}}$ Wood was impregnated with $\mathrm{Na}, \mathrm{K}$ an $\mathrm{Mg}$ salts and char fines were added to the bed.

\subsection{Results: bench scale continuous pilot plant}

After the introductory batch experiments as described in the previous sections, six runs were carried out in the continuous bench scale setup. Detailed information about the operational conditions of the experiments can be found in Table 5.5.

Table 5.5 Experimental specifications

\begin{tabular}{|l|c|c|c|c|c|c|}
\hline & Run 1 & Run 2 & Run 3 & Run 4 & Run 5 & Run 6 \\
\hline $\begin{array}{l}\text { Duration } \\
{[\text { hh:mm:ss }]}\end{array}$ & $02: 04: 14$ & $02: 48: 05$ & $02: 12: 03$ & $02: 02: 48$ & $02: 06: 46$ & $02: 03: 11$ \\
\hline $\begin{array}{l}\mathrm{T}_{\text {reactor }} \\
{\left[{ }^{0} \mathrm{C}\right]}\end{array}$ & 494 & 489 & 488 & 491 & 489 & 494 \\
\hline $\left.\begin{array}{l}\mathrm{T}_{\text {cyclones }} \\
\text { +extra filter section }[\end{array}{ }^{0} \mathrm{C}\right]$ & 409 & 406 & 405 & 415 & 498 & 405 \\
\hline Remark & & $\begin{array}{c}\text { Extended } \\
\text { run time }\end{array}$ & $\begin{array}{c}\text { Dry } \\
\text { feedstock }\end{array}$ & $\begin{array}{c}\text { Included } \\
\text { filter section } 1^{\text {a }}\end{array}$ & $\begin{array}{c}\text { Included } \\
\text { filter section 2 }\end{array}$ & $\begin{array}{c}\text { Reused } \\
\text { filter }\end{array}$ \\
\hline
\end{tabular}

\subsubsection{Operability}

Temperature, pressure, and permanent gas flow ratios have been registered and determined. Stable temperatures were obtained immediately after the start of the experiment, except for the reactor. However, after ten minutes a stationary temperature inside the reactor was reached as well.

Typical pressure profiles are shown in Figure 5.5. After an initial increase in pressure drop across the filter during the first $10 \mathrm{~min}$, a stationary pressure drop profile was obtained (except for run 2, which will be discussed later). Probably during this initial stage of $10 \mathrm{~min}$ the filter cake is formed, but apparently it does not grow in terms of filter cake resistance beyond $10 \mathrm{~min}$. A stationary pressure drop was obtained as well when a reused filter was used (Figure 5.5, run 6).

The gas flow composition remained constant during a run with the exception of the startup period of $\sim 10 \mathrm{~min}$. The permanent gas flow ratio of the filter flow divided by the 
cyclone flow in time is plotted in Figure 5.6. Apart from run 2, the ratio remained nearly constant during these runs, indicating that the filter cake resistance did not increase substantially during operation. In run 2 , the aim was to produce a relatively large quantity of filtered pyrolysis oil for further processing. For run 2, there is a quite sudden increase in the ratio of the flow through the filter compared to the flow through the cyclone lines. This might indicate leakage of the filter, but when the reactor was disassembled the cause was found to be a blockage in the cyclone line and not in the filter line!

In conclusion, good process control concerning temperature and pressure drop across the hot gas vapor filter was achieved during a $2 \mathrm{~h}$ run. The filter cake resistance did not increase noticeably during operation.

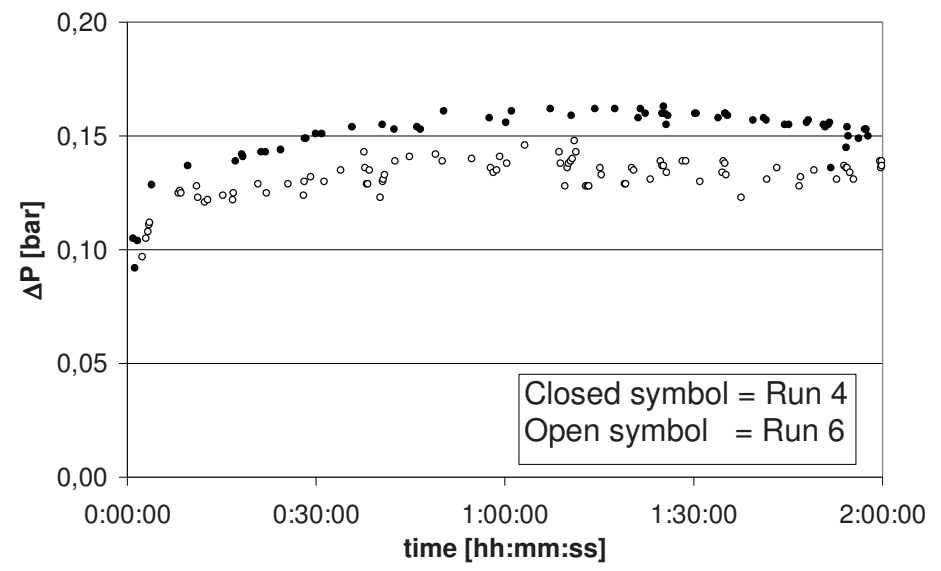

Figure 5.5 Typical pressure profile

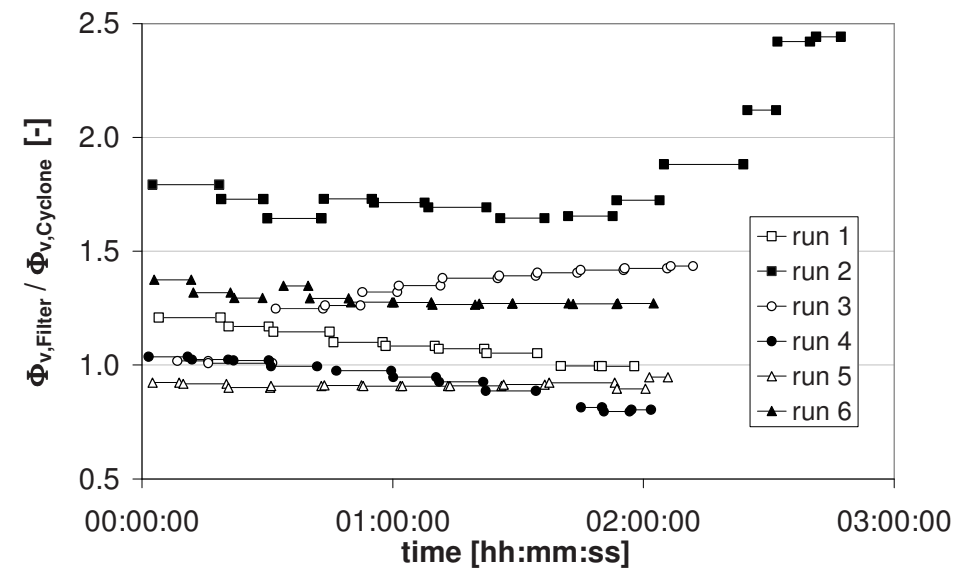

Figure 5.6 Gas flow ratio's 


\subsubsection{Mass Balance}

Mass balance closures between 94 and $97 \mathrm{wt} \%$ have been obtained. The small gaps in the mass balances (3-6\%) are possibly related to the loss of some volatile components in the oil which might escape from both condensation systems. In runs 2-4 there were some problems with the collection of the oil produced in the cyclone line due to a malfunctioning valve in the product vessel. Because of this, not all the oil could be transported out of the condenser to the collection vessel properly. This means that for experiments 2-4 the cyclone oil yield, and therewith the mass balance closure, could not be determined. Only the total amount of gases is reported in Table 5.6. No significant changes with respect to gas composition were detected between the runs and between the gases from the filter line and cyclone line. $\mathrm{CO}$ and $\mathrm{CO}_{2}$ concentrations were approximately equal and in total make up $\sim 90-93 \%$ of the produced gases. Typically 3-6 $\mathrm{wt} \%$ methane was present, and besides that minor amounts of other gases were detected. The total yields of (cyclone oil + filtered oil) obtained in this study (61-62\%) are comparable to the typical oil yields obtained in the experiments by Westerhof et al. using only the cyclones ${ }^{27}$.

Table 5.6 Mass balances [wt \%]

\begin{tabular}{|l|c|c|c|c|c|c|}
\hline & Run 1 & Run 2 & Run 3 & Run 4 & Run 5 & Run 6 \\
\hline Cyclone - Oil & 29.0 & N.A. & N.A. & N.A. & 28.9 & 23.6 \\
\hline Filter - Oil & 32.0 & 40.8 & 37.0 & 31.9 & 32.8 & 38.0 \\
\hline Char & 16.4 & 14.2 & 14.2 & 13.6 & 15.6 & 15.6 \\
\hline Cyclone - Gases & 7.8 & 7.8 & 8.8 & 11.1 & 10.1 & 7.6 \\
\hline Filter - Gases & 8.5 & 14.2 & 11.1 & 10.4 & 9.2 & 9.8 \\
\hline Total & 93.7 & N.A. & N.A. & N.A. & 96.6 & 94.6 \\
\hline
\end{tabular}

\subsubsection{Wire Mesh Filter inside Fluidized Bed}

SEM pictures of the custom-made wire mesh filter surface area were made after the experiments. A selection of the SEM photos is shown in Figure 5.7. A uniform distribution of particles, metal wires, and pores can be observed for the whole surface area. A clear difference can be seen between the inside and the outside of the filters. Particles are retained inside the filter pores located near the outside surface area of the filter. SEM-energy dispersive X-ray (EDX) analyses have shown that these particles consist of a mixture of char ( $\mathrm{C}$ and $\mathrm{O})$, sand ( $\mathrm{Si}$ ), and some alkali metals. A closer look at one of the filter pores located at the outside of the filter is given in Figure 5.7 ("close up pore-outside"). This picture shows the remaining open area in between the particles available for hot gas vapor filtration. This filter cake inside the pores might even play a role in the filtering mechanism, as it may filter out progressively finer solids. The inside of both filters remained clean apart from some deposits formed on the metal wire. Only some $1 \mu \mathrm{m}$ particles were detected on the inside, which seems to indicate that hardly any 
bigger particles have passed through the filter. Furthermore, it is important to point out the similarities between the pictures of the filters used in run 1 and run 6 . A new filter was used in the first run (run 1) compared to a reused one in the last run (run 6). Visually equal amounts of particles have been retained inside the filter pore, which indicates that no continuous plugging of the filter pores occurs during a $2 \mathrm{~h}$ run. This last observation is supported by the reported pressure drop development shown in Figure 5.5.
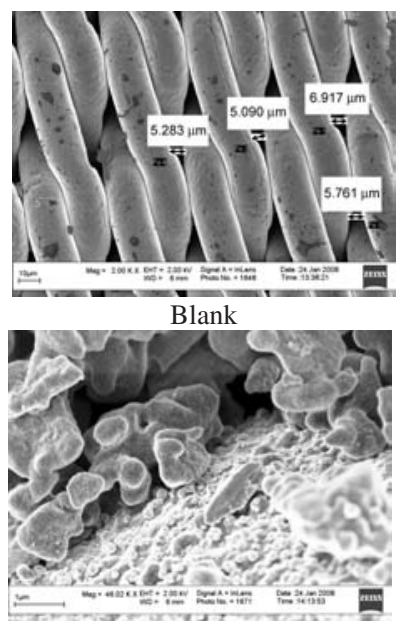

Run 1 - Close up pore - outside

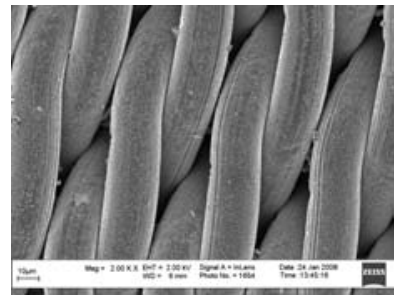

Run 1 - Inside

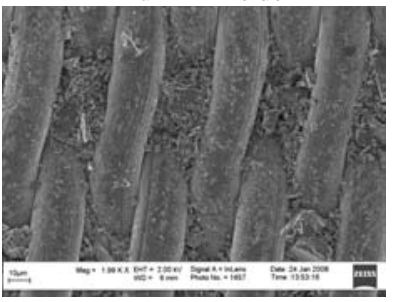

Run 1 - Outside

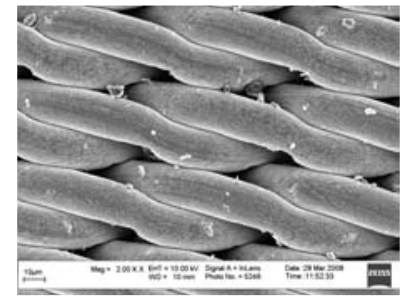

Run 6 - Inside

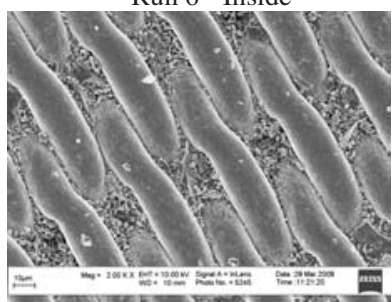

Run 6 - Outside

Figure 5.7 SEM images of the wire mesh filter, images made after the experiments. In Run 6 a re-used filter was used

\subsubsection{Pyrolysis Oil Properties}

The pyrolysis oil collected inside the countercurrent spray column (Figure 5.3, 13) for both the cyclone line and filter line was analyzed and compared. The oil collected inside the intensive cooler was not analyzed (Figure 5.3,14), but this will not result in major deviations, because around $95 \mathrm{wt} \%$ of the oil was already collected in the countercurrent spray columns. Both the cyclone oil and filtered oil had the same appearance: uniform and one phase. The representativeness of the oil samples used for analysis (with respect to the total batch of oil produced) was determined by measuring the water content of various samples taken from the same batch of oil. The difference was at maximum 0.5 $\mathrm{wt} \%$, which is within the limits of the accuracy of the method. Using extensive analytical techniques, some significant differences between the cyclone and filtered oil could be determined (see also Table 5.7). 
Table 5.7 Results pyrolysis oil properties collected in the first condenser

\begin{tabular}{|c|c|c|c|c|c|c|c|}
\hline & $\Delta \mathrm{x}$ & Run 1 & Run 2 & Run 3 & Run 4 & Run 5 & Run 6 \\
\hline \multicolumn{8}{|l|}{ Results cyclone oil } \\
\hline Solid content [wt\%] & 0.02 & 0.06 & 0.09 & 0.03 & 0.06 & 0.04 & 0.05 \\
\hline Ash content [wt $\%]$ & 0.002 & \multicolumn{5}{|c|}{ N.A. ${ }^{a}$} & 0.033 \\
\hline \begin{tabular}{|l} 
Water content $[\mathrm{wt} \%]$ \\
\end{tabular} & 0.5 & 31.8 & 31.7 & 20.8 & 27.3 & 29.4 & 28.6 \\
\hline $\mathrm{C}_{\mathrm{dry}}[\mathrm{wt} \%]$ & 0.3 & 51.3 & 53.2 & 52.6 & 54.5 & 54.9 & 54.8 \\
\hline $\mathrm{H}_{\mathrm{dry}}[\mathrm{wt} \%]$ & 0.5 & 5.9 & 5.6 & 7.1 & 6.4 & 6.2 & 6.2 \\
\hline $\mathrm{O}_{\text {dry }}[\mathrm{wt} \%]$ & 0.8 & 42.9 & 41.1 & 40.3 & 39.1 & 38.9 & 39.0 \\
\hline $\mathrm{H} / \mathrm{C}[\mathrm{mol} / \mathrm{mol}]$ & 0.08 & 1.4 & 1.3 & 1.6 & 1.4 & 1.3 & 1.4 \\
\hline $\mathrm{O} / \mathrm{C}[\mathrm{mol} / \mathrm{mol}]$ & 0.02 & 0.63 & 0.58 & 0.57 & 0.54 & 0.53 & 0.53 \\
\hline$<\mathrm{M}_{\mathrm{z}}>[\mathrm{g} / \mathrm{mol}]$ & N.A. & 388 & N.A. & 365 & 384 & 317 & 338 \\
\hline \multicolumn{8}{|l|}{\begin{tabular}{|l|} 
Results filtered oil \\
\end{tabular}} \\
\hline Solid content [wt\%] & 0.0006 & \multicolumn{6}{|c|}{$<$ detection limit } \\
\hline Ash content [wt $\%]$ & 0.001 & \multicolumn{5}{|c|}{ N.A. $^{a}$} & 0.013 \\
\hline \begin{tabular}{|l} 
Water content [wt\%] \\
\end{tabular} & 0.5 & 26.4 & 26.5 & 21.0 & 23.3 & 25.2 & 24.7 \\
\hline $\mathrm{C}_{\mathrm{dry}}[\mathrm{wt} \%]$ & 0.3 & 55.9 & 54.1 & 54.5 & 55.4 & 55.8 & 55.1 \\
\hline $\mathrm{H}_{\mathrm{dry}}[\mathrm{wt} \%]$ & 0.5 & 5.4 & 5.6 & 6.4 & 6.6 & 6.5 & 6.4 \\
\hline $\mathrm{O}_{\text {dry }}[\mathrm{wt} \%]$ & 0.8 & 38.7 & 40.4 & 39.1 & 38.0 & 37.7 & 38.4 \\
\hline $\mathrm{H} / \mathrm{C}[\mathrm{mol} / \mathrm{mol}]$ & 0.08 & 1.1 & 1.2 & 1.4 & 1.4 & 1.3 & 1.4 \\
\hline $\mathrm{O} / \mathrm{C}[\mathrm{mol} / \mathrm{mol}]$ & 0.02 & 0.52 & 0.56 & 0.54 & 0.51 & 0.51 & 0.52 \\
\hline$<\mathrm{M}_{\mathrm{z}}>[\mathrm{g} / \mathrm{mol}]$ & N.A. & 372 & 250 & 353 & 349 & 294 & 312 \\
\hline
\end{tabular}

$\underline{\text { Solids, ash, and alkali/alkaline earth metal content }}$

Just as in the batch experiments described in section 5.4, the filtered oil contains significantly less solids, alkali metals, and ash compared to cyclone oil (Table 5.7 and Figure 5.8). The solid content in filtered oil was even below the detection limit. For the alkali metals, only a considerable amount of potassium $(\mathrm{K})$ is still present in filtered pyrolysis oil (Figure 5.8). These results are in agreement with the results from the batch experiments (section 5.4). Equilibrium calculations were performed using the program Equitherm v3.0, a database (Barin) software package for thermodynamic calculations. The equilibrium composition was determined by minimizing the Gibbs energy of the system. The possible states (oxides, hydroxides, carbonates, chlorides, nitrates) of various potassium, magnesium, calcium, and sodium salts were calculated under pyrolysis conditions $\left(500{ }^{\circ} \mathrm{C}, 1.013 \mathrm{bar}\right)$. Although in general there seems to be a lack of reliable thermodynamic data at these conditions, results of thermodynamic calculations can be used as first indication of the distribution of alkali/alkaline earth components between the gas and solid phases. These calculations show that almost all salts are in the solid state. 
However, a considerable amount of potassium and a small amount of sodium can be present in the gas phase. Experimental studies were carried out by Keown et al. (Na, K, $\mathrm{Mg}, \mathrm{Ca})^{31}$ and Olsson et al. $(\mathrm{Na}, \mathrm{K})^{32}$ on the volatilization of alkali/alkaline earth metals from biomass. Keown et al. ${ }^{31}$ showed that the volatilization of alkali/alkaline earth species depends on many factors such as biomass properties, valence of the metals, heating rate, and temperature. Detailed mechanisms remained unclear, although results seem to indicate that besides thermodynamic equilibrium considerations also kinetically related issues are of influence. Both research groups ${ }^{31,32}$ observed the release of potassium and sodium under pyrolysis conditions. Only if bagasse was used as feedstock, the release of magnesium and calcium was additionally observed by Keown et al. ${ }^{31}$ For a cane trash feedstock no release of these alkaline earth metals was detected. ${ }^{31}$ However, the results obtained with the experimental setup used by Keown et al. ${ }^{31}$ might be questionable as a quartz frit was installed in the freeboard of a fluidized bed reactor to prevent char elutriation during pyrolysis. If even small quantities of char would have slipped through this frit, this would lead to erroneous results and a substantial overestimation of the true volatization of alkali/alkaline earth salts.

Although no unambiguous conclusion can be drawn from the thermodynamic calculations and the available (experimental) literature data, they support the current hypothesis that, even when a filter is used and a char-free pyrolysis oil is obtained, alkali/alkaline earth salts can still be present in pyrolysis oil to a measurable extent if the vapor pressure of these salts is relatively high.

Altogether, under our reaction conditions the solids, ash, and alkali metal contents in pyrolysis oil could be reduced significantly by in situ hot gas vapor filtration compared to the oil produced via the cyclone line. Only a considerable amount of potassium $(\mathrm{K})$ is still present in filtered pyrolysis oil, which probably originates from the vapor phase.

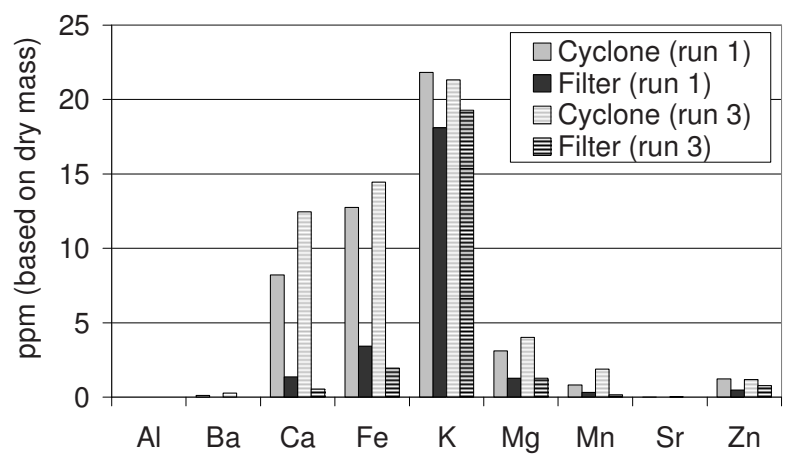

Figure 5.8 Alkali metals in pyrolysis oil, as determined by vTI, Hamburg 


\section{Elemental composition}

There were no significant differences in the elemental composition of the oil produced via the filter line and cyclone line. Both the hydrogen over carbon and oxygen over carbon mole ratios seem to be slightly lower for the filtered oil compared to the cyclone oil. However, these differences are in the same range as the margin of error (see Table 5.7 for the values).

\section{Molecular weight distribution}

The molecular weight distribution is plotted in Figure 5.9, in which the differential distribution $d_{\text {total mass }} / d_{\log \text { molar mass }}(W(\log M))$ is plotted versus the of the molecular mass $(M)$. The molecular weight of the filtered oil obtained with non dried feed was always marginally lower than that for the cyclone oil (see Table 5.7 and Figure 5.9). Remarkably, run 3-which used a dry feed-yielded a near equal molecular weight distribution of both oils. A lower average molecular weight of the oil is generally believed to result in a better combustion performance ${ }^{24}$. A lower molecular weight might have a positive effect for the upgrading processes as well. The molecular weight of pyrolysis oil is likely to be influenced by two mechanisms: (1) cracking reactions resulting in a lower molecular weight; (2) condensation/polymerization reactions resulting in a higher molecular weight ${ }^{30}$. Similar to the results in this study, Shihadeh ${ }^{24}$ and Oasmaa and Czernik ${ }^{10}$ reported a lower average molecular weight for the filtered oil compared to cyclone oil (see section 5.2). In our experiments the lower molecular weight of the filtered oil compared to the cyclone oil cannot be explained by more severe cracking of pyrolysis vapors due to an extended residence time since the residence time of the vapors in the filter line is much shorter than the residence time in the cyclone line (Table 5.3, 0.8 vs. 2.5 s). It might be possible that in the filter line more extensive cracking occurs due to high intensity contact of the vapors with char/ ash inside the filter pores $^{11}$ (Figure 5.7). However, with respect to the gas composition no significant differences were detected between the filter line and the cyclone line, which would be expected if this phenomenon did occur. Only a slightly higher concentration of methane ( $(1 \mathrm{wt} \%)$ can be distinguished in the filter line, which might be an indication for extended cracking reactions. The lower molecular weight of the filter line oil can also be explained by a lower extent of polymerization/condensation reactions inside the filter line due to the shorter residence time. This last hypothesis is supported by the lower water content observed in the filtered oil compared to the cyclone oil (see next section). 


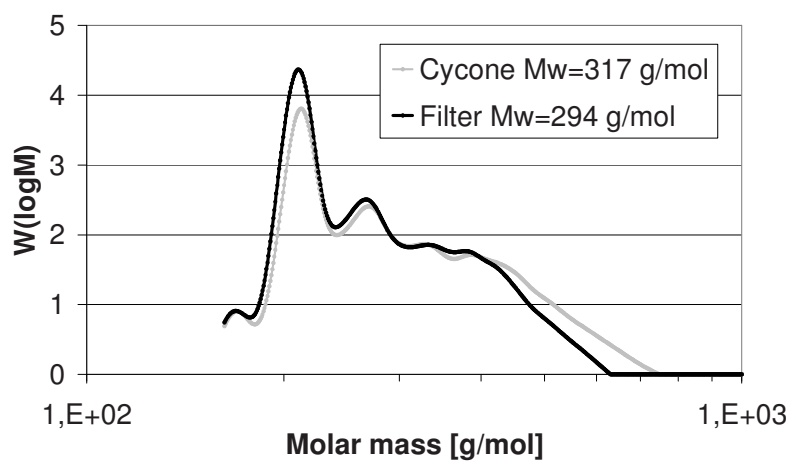

Figure 5.9 Molecular weight distribution (run 5)

\section{Water content}

Water inside pyrolysis oil originates from the moisture in the feedstock and the water produced by chemical reactions ${ }^{33}$. The water content of the filtered oil was between 3.9 and $5.4 \mathrm{wt} \%$ lower than the water content of the cyclone oil (Table 5.7). Again, run 3 which uses a dry feedstock is an exception to this, as in this experiment the weight percent of water was identical for both the filtered oil and the cyclone oil. Two possible reasons for the observed differences in water content will be discussed below:

1. Fewer dehydration reactions inside the filter line might explain the lower water content of the filtered oil. Dehydration reactions (increasing water content) results in lower $\mathrm{H} / \mathrm{C}$ and $\mathrm{O} / \mathrm{C}$ ratios of the oil. Yet, the detailed water formation reactions are largely unknown. However, it is generally accepted in the literature that water is formed by both condensation ${ }^{12}$ and cracking reactions ${ }^{26}$ accompanied by an increase and decrease in molecular weight, respectively. The $\mathrm{H} / \mathrm{C}$ and $\mathrm{O} / \mathrm{C}$ ratios for filtered oil seem to be marginally lower than for cyclone oil (Table 5.7), as well as the molecular weight (Table 5.7).

2. Different preference flows of water vapor originating from physically bound water in biomass might be another explanation. When exposed to the high temperatures in the reactor, the physically bound water originating from the feedstock will probably directly vaporize near the feedstock entrance. It might be that because of preferential flows this water will not be distributed equally between the filter line and the cyclone line. This way, this water vapor flow can bypass the filter and end up in the cyclone oil for a somewhat larger part. This hypothesis is supported by the results of run 3 , in which a predried feedstock was used. In this particular case the water content of the filtered oil and cyclone oil was identical. 
Although a difference in the water content of the filtered oil and pyrolysis oil can be observed, the analysis above indicates that is probably due to a nonhomogeneous vaporization of the water in the feed. However, it cannot be excluded that different reactions occurred in the filter line and the cyclone line.

\section{Stability}

With respect to the pyrolysis oil quality, the (aging) stability is a very important parameter. Pyrolysis oil still contains considerable quantities of reactive components such as organic acids, alcohols, aldehydes, phenolics, and unsaturated compounds ${ }^{12}$. During aging, chemical reactions of these components occur, resulting in an increase in molecular weight ${ }^{12}$. To compare the stability of filtered versus nonfiltered pyrolysis oil, aging tests have been carried out. The observed molecular weight increase during the aging test $\left(24 \mathrm{~h}\right.$ storage at $80{ }^{0} \mathrm{C}^{28}$ ) for filtered oil and cyclone oil (run 5) is shown in Figure 5.10. Both the filtered and cyclone oils show a considerable increase in molecular weight; however, the increase for the filtered oil seems to be somewhat less. As already noted in the Introduction, it is generally accepted in the literature that char and ash appear to catalyze polymerization reactions during storage, leading to an increase in molecular weight ${ }^{12}$. However, also in the absence of char/ash a considerable extent of aging takes place as the average molecular weight of solids-free filtered oil increases dramatically. The observed small difference between filtered oil and cyclone oil upon aging is probably due to the already very low solids content and thus good quality of the cyclone oil compared to conventional pyrolysis processes. Looking at Figure 5.1, it can be seen that, for low solids content of the oil, the aging -expressed by the increase in viscosity- seems to be limited. The solids contents of both the filtered oil (ash content) $0.013 \mathrm{wt} \%$, Table $5.7)$ and the cyclone oil (0.033 wt\%, Table 5.7) are so low that hardly any aging can be expected based on Figure 5.1. Still, the molecular weight distributions before and after aging indicate some considerable changes in both the filtered oil and cyclone oil upon aging. This indicates two things:

1. The reactivity of pyrolysis oil can already originate from the highly reactive components in pyrolysis oil itself and does not need the presence of char/ash (although these might speed up the process).

2. The aging test based on an increase in viscosity might be a relatively insensitive method to indicate changes of the oil compared to the molecular weight distribution. To study the reactivity of filtered - and thus ash- and char- free pyrolysis oil vapors, additional experiments have been carried out that will be discussed in section 5.5.5. 


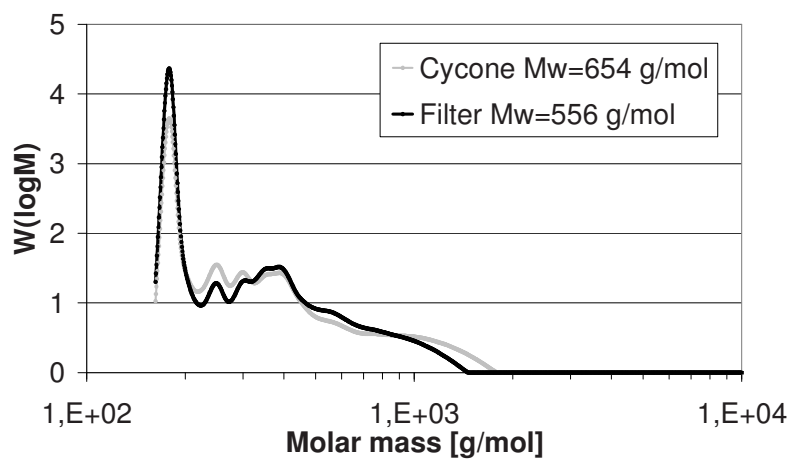

Figure 5.10 Molecular weight distribution after aging: 24 hours at $80{ }^{\circ} \mathrm{C}$ (run 5)

\subsubsection{Char Formation after Filter}

An external filter section placed directly after the reactor was incorporated in the filter line in runs 4 and 5 (Table 5.8; see also Figure 5.3, no. 8, for the exact placement of the filters). This was done to be able to study the intrinsic high reactivity of components inside particle-free pyrolysis vapors and to observe possible char formation accompanying these reactions. These external filter sections were placed in series with the wire mesh filter inside the fluidized bed. The temperature inside this external filter train could be regulated separately from the reactor with oven 2 (Figure 5.3). Two different external filter sections were tested. Detailed information is shown in Table 5.8. The additional residence time caused by these external filter sections was relatively small compared to the total vapor residence time and estimated to be at maximum $0.006 \mathrm{~s}$.

Table 5.8 External filter section

\begin{tabular}{|l|l|l|}
\hline & Used series of filters & Temperature \\
\hline Run 4 - filter section 1 & $\mathrm{F}-\mathrm{M}$ & $400^{\circ} \mathrm{C}$ \\
\hline Run 5 - filter section 2 & $\mathrm{F}-\mathrm{G}-\mathrm{F}-\mathrm{G}-\mathrm{F}-\mathrm{G}-\mathrm{F}-\mathrm{G}-\mathrm{M}$ & $500{ }^{\circ} \mathrm{C}$ \\
\hline
\end{tabular}

F: Filter, pore size $1 \mu \mathrm{m}$, Schleicher \& Schuell, glass fiber filter paper, GF $50, \phi=90 \mathrm{~mm}$

M: Metal support, Dinxperlo, Wire Weaving co. LTD, AISI 316, Mesh 200•200, wire thickness $0.06 \bullet 0.06 \mathrm{~mm}$, twilled weave G: Glass frit support

In run 4 a $1 \mu \mathrm{m}$ glass filter and a metal support were placed outside the reactor, but in series with the internal filter. The temperature of the external filter train in run 4 was set to $400{ }^{0} \mathrm{C}$, which equals the standard cyclone temperature. As expected, some $1 \mu \mathrm{m}$ slipped through the internal filter (Figure 5.7, Inside) and black deposits were formed on the front side of the glass filter. Remarkably, deposits were also formed on both the back side of the $1 \mu \mathrm{m}$ glass filter and the metal support (Figure 5.11). If this was char originating from pyrolysis vapors, it must have been formed after the first glass filter, indicating very rapid reactions. However, the char on the metal support could also be due 
to the formation of crystalline carbon nanofibers, because metals tend to catalyze the growth of carbon nanofibers. Typically, methane, carbon monoxide, synthesis gas $\left(\mathrm{H}_{2} / \mathrm{CO}\right)$, ethyne, and ethane in the temperature range $427-927{ }^{\circ} \mathrm{C}$ can provide the carbon atoms for nanofibers ${ }^{34}$. SEM-EDX analysis of the char on the metal filter indicated the presence of oxygen besides carbon in the filaments. Furthermore, no crystalline structure could be detected using XRD. From both observations it becomes clear that no carbon nanofibers have been formed on the metal support and that the char particles around the glass fibers at the back side of the filter originate from pyrolysis oil vapors. Several of these particles are larger than $10 \mu \mathrm{m}$ (see Figure 5.11, left), so it is not possible that these particles have slipped through the $1 \mu \mathrm{m}$ glass filter during the run. Both observations support the hypothesis that char can be formed from particle-free pyrolysis vapors.

In run 5, the external filter section was further extended for a more thorough understanding of the char formation reactions. Four $1 \mu \mathrm{m}$ glass filters and glass supports were placed in alternating order in series. A metal support was placed after this series. The glass supports were used to exclude any possible catalytic effects which might theoretically occur when using metal supports. This time the temperature of the second oven was set to $500{ }^{\circ} \mathrm{C}$ (reactor temperature) to prevent possible condensation inside this external filter section. Both front and back view pictures of the used glass filters and supports are shown in Figure 5.12. Initially, the color was white for both the supports and filters. Looking at the color, a bit more char deposits seem to be formed at the first filter, although it can be clearly observed that some char is formed at the last filter as well. This is an important indication for the occurrence of char formation reactions inside the vapor phase. From the SEM photos of the front and back views of the $1 \mu \mathrm{m}$ glass filters (Figure 5.13), it becomes clear that fewer particles have been formed further down the filter train, although some deposits have been formed on the surface of the fibers. Possible reasons for this include 1) the most reactive components have been removed from the vapors by the first filters and 2) fewer particles have been formed due to the very short residence time between the filters.

The results in runs 4 and 5 with respect to the external filter section show that char formation reactions inside a particle free vapor stream take place. 


\section{Chapter 5}

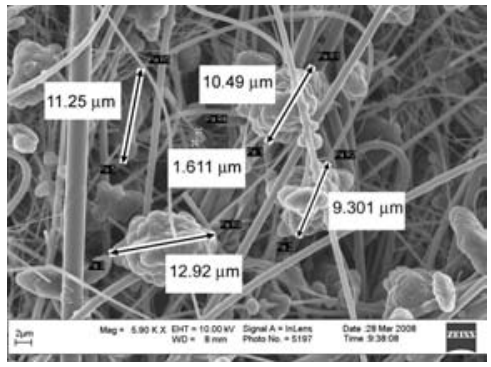

Back view $1 \mu \mathrm{m}$ glass filter

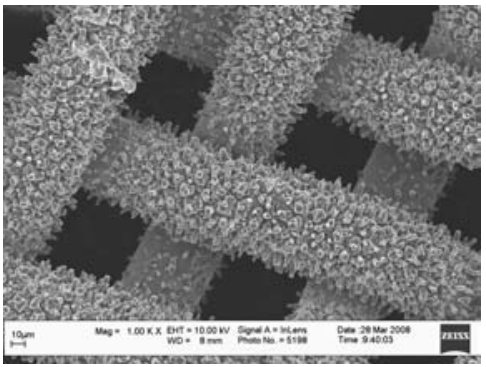

Front view metal support

Figure 5.11 SEM Photo's external filter section (run 4)

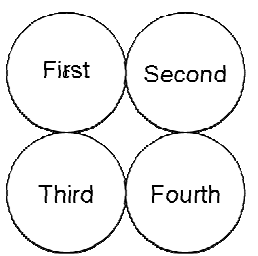

Filter order

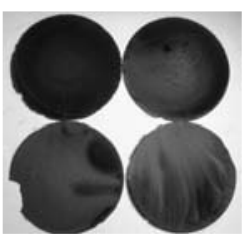

Front view

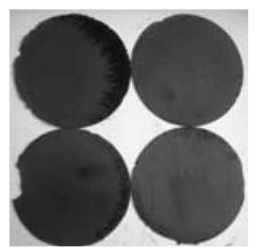

Back view

Glass filter

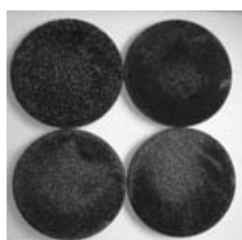

Front view

Glass support

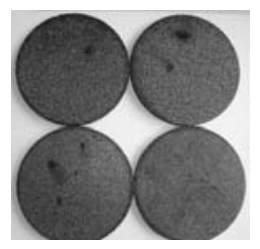

Back view

Glass support

Figure 5.12 Photo's external filter section. Some of the glass filters partly broke during removal from the filter but where intact during operation. (run 5)

SEM photo's Front view

SEM photo's Back view
First glass filter

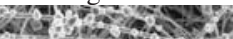

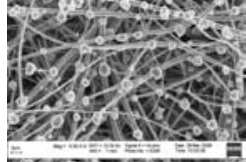

First glass filter

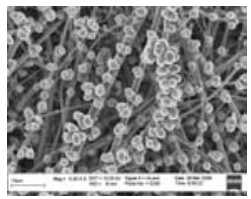

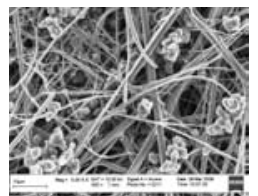

Second glass filter ME $900 \%$ or.

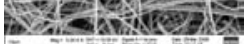

Second glass filter

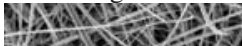

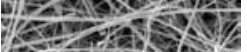

Figure 5.13 SEM - photo's external filter section (run 5)

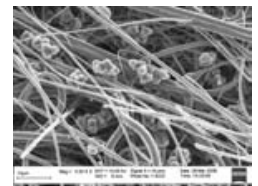

Third glass filter

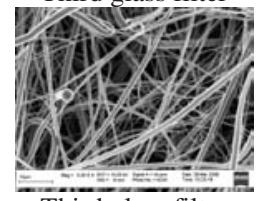

Third glass filter

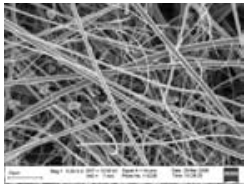

Fourth glass filter
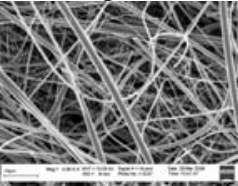

Fourth glass filter 


\subsection{Conclusions}

This study shows that the two main problems reported in the literature related to downstream hot gas vapor filtration do not play a role during multiple $2 \mathrm{~h}$ runs in a fluidized bed pilot plant with immersed filters.

1. Good process stability concerning pressure drop across the hot gas vapor filter was achieved during runs of typically $2 \mathrm{~h}$, even when a reused filter was applied (Figure 5.5). The outer surface of the filters is probably cleaned continuously due to the sourcing action of the bed particles resulting in a constant pressure drop across the filter.

2. Total yields of (cyclone + filtered oil) were comparable to the yields obtained in the experiments using only the cyclones (Table 5.6). The integration of the filter in the fluidized bed prevents an increased pyrolysis vapor residence time as observed with external filtering of pyrolysis oil vapors, thereby probably preventing excessive secondary cracking reactions and lowering of the oil yield.

The quality of the filtered oil is better than the one of the cyclone oil: the filtered oil contains significantly less solids, alkali metals, and ash compared to cyclone oil (Table 5.7, Figure 5.8). Only a considerable amount of potassium $(\mathrm{K})$ is still present in filtered pyrolysis oil, which probably originates from the vapor phase. There were no significant differences in the elemental composition of the oil produced via the filter line and the cyclone line (Table 5.7). The molecular weight and the water content of the filtered oil obtained with nondried feed were always marginally lower than the ones for the cyclone oil (Figure 5.9 and Table 5.7, respectively). Results of the aging tests ( $24 \mathrm{~h}$ storage at 80 ${ }^{0} \mathrm{C}$ ) show that the reactivity of pyrolysis oil can already originate from the highly reactive components in pyrolysis oil itself and does not need the presence of char/ash (Figure 5.10). Additional experiments showed that some char is formed from a solids-free vapor stream, again indicating a high intrinsic reactivity of the pyrolysis components. 


\section{Chapter 5}

\section{References}

1. A.V. Bridgwater, G.V.C. Peacocke, Fast pyrolysis processes for biomass, Renew. Sustain. Energ. Rev., 4(1), 1-73, 2000

2. A.V. Bridgwater, Renewable fuels and chemicals by thermal processing of biomass, Chem. Eng. J., 91, 87-102, 2003

3. K. Sipila, E. Kuoppala, L. Fagernas, A Oasmaa,. Characterization of biomass-based flash pyrolysis oils, Biomass and Bioenergy, 14(2), 102-113, 1998

4. S. Czernik; A.V. Bridgwater, Overview of applications of biomass fast pyrolysis oil, Energy and Fuels, 18 (2), 590-598, 2004

5. A. Gutierrez, M.E. Domine, Y. Solantausta, Copressing of upgraded bioliquids in standard refinery units fundamentals, Proceedings 15th European Biomass Conference \& Exhibition, 7-11 May 2007, Berlin, Germany

6. M.F. Bleeker, S.R.A. Kersten, H.J. Veringa, Pure hydrogen from pyrolysis oil using the steamiron process, Catal. Today, 127 (1-4), 278-290, 2007

7. F.A. Agblevor, S. Besler, Inorganic compounds in biomass feedstocks 1. Effect on the quality of fast pyrolysis oils, Energy and Fuels, 10, 293-298, 1996

8. F.A. Agblevor, S. Besler, R.J. Evans, Inorganic compounds in biomass feedstocks their role in char formation and effect on the quality of fast pyrolysis oils, Proceedings pyrolysis oil properties and combustion meeting, 26-28 September 1994, Colerado

9. J.P. Diebold, S. Czernik, J.W. Scahill, S.D. Phillips, C.J. Feik, Hot gas filtration to remove char from pyrolysis vapors produced in the vortex reactor at NREL, Proceedings pyrolysis oil properties and combustion meeting, 26-28 September 1994, Colerado

10. A. Oasmaa, S. Czernik, Fuel oil quality of biomass pyrolysis oils - state of the art for the end users, Energy and Fuels, 13, 914-921, 1999

11. M.K. Boroson, J.B. Howard, J.P. Longwell, W.A. Peters, Heterogeneous cracking of wood pyrolysis tars over fresh wood char surfaces, Energy and Fuels, 3, 735-740, 1989

12. J.P. Diebold, A review of the chemical and physical mechanisms of the storage stability of fast pyrolysis bio-oils, 1999

13. J.P. Diebold, J.W. Scahill, S Czernik, S.D. Phillips, C.J. Feik, Progress in the production of hotgas filtered biocrude oil at NREL, 1995

14 J.P. Diebold, S. Czernik, Additives to lower and stabilize the viscosity of pyrolysis oils during storage, Energy and Fuels, 11, 1081-1091, 1997

15 S. Czernik, D.K. Johnson, S. Black, Stability of wood fast pyrolysis oil, Biomass and Bioenergy, 7, 187-192, 1994

16. J. Sitzmann, A.V. Bridgwater, Upgrading fast pyrolysis oil by hot vapour filtration, 15th European Biomass Conference \& Exhibition, 7-11 May 2007, Berlin, Germany

17. X. Wang, A.H.G. Cents, G. van Rossum, S.R.A. Kersten, W.P.M. Van Swaaij, Fast pyrolysis of biomass in a fluidized bed reactor: hydrodynamics of the bed during in-situ filtering, to be published

18. Y. Solantausta, A Oasmaa, M Nieminen, Hot filtration of fast pyrolysis vapours, Project Report : PROX/Pnnn/07, 2004

19. K.H. Lee, B.S. Kang, Y.K. Park, J.S. Kim, Influence of reaction temperature, pretreatment, and a char removal system on the production of bio-oil from rice straw, using a fluidized bed, Energy and Fuels, 19, 2179-2184, 2005

20. B.S. Kang, K.H. Lee, H.J. Park, Y.K. Park, J.S. Kim, Fast pyrolysis of radiate pine in a bench scale plant with a fluidized bed: influence of a char separation system and reaction conditions on the production of bio-oil, J. Anal. Appl. Pyrolysis, 76, 32-37, 2006

21. H.J. Park, Y.K. Park, J.S. Kim, Influence of reaction conditions and the char separation system on the production of bio-oil from radiate pine sawdust by fast pyrolysis, Fuel Process. Technol., 89(8), 797-802, 2008

22. S.H. Jung, B.S. Kang, J.S. Kim, Production of bio-oil from rice-straw and bamboo sawdust under various reaction conditions in a fast pyrolysis plant equipped with a fluidized bed and a char separation system, J. Anal. Appl. Pyrolysis, 82(2), 240-247, 2008

23 J. Scahill, J.P Diebold, C. Feik, Removal of residual char fines from pyrolysis vapors by hot gas filtration in Bridgwater, Boocock, Developments in thermochemical biomass conversion, London: Blackie Academic \& Professional, 253-266, 1997 
24. A.L. Shihadeh, Rural electrification from local resources: biomass pyrolysis oil combustion in a direct injection diesel engine. Ph.D. Thesis, Massachussetts Institute of Technology, 1998

25. X. Wang, Biomass Fast Pyrolysis in a fluidized bed Product cleaning by in-situ filtration, $\mathrm{PhD}$ thesis, University of Twente, 2006

26. X. Wang, S.R.A. Kersten, W. Prins. Biomass pyrolysis in a fluidized bed reactor. Part 2: Experimental validation of model results, Ind. Eng. Chem. Res., 44, 8786 - 8795, 2005

27. R.J.M. Westerhof, N.J.M. Kuipers, S.R.A. Kersten, W.P.M. Van Swaaij, Controlling the water content of biomass fast pyrolysis oil, Ind. Eng. Chem. Res., 46, 9238 - 9247, 2007

28. A. Oasmaa, C. Peacocke, A guide to physical property characterization of biomass-derived fast pyrolysis liquids, VTT, Technical Research Centre of Finland, Espoo, 2001

29. A.V. Bridgwater, S. Czernik, J.P. Diebold, D Meier, A. Oasmaa, C. Peacocke, J. Piskorz, D. Radlein, Eds., Fast Pyrolysis of biomass; A handbook, CPL Press, 1999

30. A.V. Bridgwater, D. Meier, D. Radlein, An overview of fast pyrolysis of biomass, Org. Geochem., 30, 1479-1493,1999

31. D.M. Keown, G. Favas, J. Hayashi, C.Z. Li, Volatilisation of alkali and alkaline earth metallic species during the pyrolysis of biomass: differences between sugar cane bagasse and cane trash, Bioresour. Technol., 96, 1570-1577, 2005

32. J.G. Olsson, U. Jäglid, J.B.C. Pettersson, Alkali metal emission during pyrolysis of biomass, Energy and Fuels, 11, 779-784, 1997

33. S.R.A. Kersten, X. Wang, W. Prins, W.P.M. Van Swaaij, Biomass pyrolysis in a fluidized bed reactor. Part 1: Literature review and model simulations, Ind. Eng. Chem. Res., 44(23), 87738785,2005

34. K. De Jong, J.W. Geus, Carbon nanofibers: catalytic synthesis and applications, Catal. Rev. - SCI. Eng., 42(4), 481-510, 2000 


\section{Chapter 6}

\section{Possibilities and pitfalls in}

\section{analyzing (upgraded) pyrolysis oil by size exclusion chromatography (SEC)}

The applicability of size exclusion chromatography (SEC) to analyze (upgraded) pyrolysis oil samples has been studied using model compounds, pyrolysis oils and hydrodeoxygenated pyrolysis oils. The assumptions needed for the conversion of the chromatogram to the $M_{w}$-distribution were validated. It was shown that the conversion of elution volume to molecular weight (based on polystyrene calibration curves) can introduce substantial errors in the prediction of the molecular weight. The conversion of $R I D$ response to $W(\log M)$ (as plotted on the y-axis of the $M_{w}$-distribution) is based on the assumption of a compound independent RID response factor and linear response to concentration. While the latter was shown to be true within the concentration range studied, the former was not true: the RID response factor depends on the type of (upgraded) pyrolysis oil. It was shown that within a single pyrolysis oil sample, the RID response for the low molecular weight fraction was a factor 3 lower than the high molecular weight fraction. Furthermore long term column fouling can influence SEC results that cannot be corrected with regular polystyrene recalibrations. Based on the results we recommend SEC not to be used as a quantitative method for characterization (upgraded) pyrolysis oil samples, but as a tool to compare (upgraded) pyrolysis oil samples, preferably prepared using incremental operating conditions and expected to have similar molecular composition. This work has further shown that (i) the $\int U V D d v / \int R I D d v$ ratio can be used as an indication of the sum of the relative aromaticity and conjugated double bond content for (upgraded) pyrolysis oil, and (ii) the negative peak area appearing in the low molecular weight part of the chromatogram can be used to estimate the water content of (upgraded) oil samples. 


\subsection{Introduction}

Pyrolysis oil (or bio crude) is produced by heating biomass rapidly to $450-500{ }^{\circ} \mathrm{C}$ in the absence of oxygen under atmospheric pressure and rapid quenching of the hot vapors. The composition of pyrolysis oil depends on a number of factors including feedstock, particle size, and reaction parameters ${ }^{1}$. Generally, pyrolysis oil is a complex mixture of hundreds of oxygenated compounds with a wide molecular weight range; the major chemical groups are water (15-30 wt\%), monomeric carbonyls, sugars, organic acids, phenols, and oligomeric moieties from carbohydrates and lignin degradation ${ }^{2}$. Due to this complex nature, pyrolysis oil still suffers from a limited number of commercial uses, although much (research) effort is aimed at its utilization as heavy fuel substitute or after upgrading by hydrodeoxygenation (HDO) as transportation fuel ${ }^{3}$. Owing to the complex nature of pyrolysis oil and its intrinsic instability ${ }^{4}$, chemical characterization of fastpyrolysis oil is challenging. Physico-chemical analytical techniques (e.g. viscosity, water content, and elemental composition) are available, but provide limited information to characterize the oil ${ }^{5}$. Analyses at the molecular level (e.g. NMR, FTIR, LC, GCMS/FID and several fractionation schemes) are still under development ${ }^{6}$. An important technique to analyze pyrolysis oil and also upgraded pyrolysis oil (further referred to as (upgraded) pyrolysis oil) is size exclusion chromatography (SEC), also known as gel permeation chromatography (GPC). With this technique an indication of the molecular mass distribution of a sample can be obtained ${ }^{6,7}$. Using SEC for analyzing (upgraded) pyrolysis oil has major advantages: the whole oil can be analyzed, and SEC requires a low amount of sample $(\sim 30 \mathrm{mg})$. The analyses are carried out at low temperatures $\left(30-40{ }^{0} \mathrm{C}\right)$ preventing reactions during the analysis itself.

Originally, SEC was developed to determine the molecular weight distribution of polymers. A comprehensive overview on SEC can be found elsewhere ${ }^{8,9}$. However, this technique was also used to analyze oils from different sources, including $\operatorname{coal}^{10}$, petroleum $^{11-14}$, plastic wastes $^{15-18}$, lignins ${ }^{19-23}$ and biomass like (upgraded) pyrolysis oil $^{6,18,24-30}$. The interpretation of the SEC chromatograms of biomass-derived samples is not so straightforward as for polymers, since there is a lack of appropriate standards. This was illustrated by inter-laboratory differences as reported in Round Robin Tests of lignin $^{20,22}$. Garcia-Perez et al. ${ }^{27}$ and Johnson and Chum ${ }^{30}$ have reported SEC results of pyrolysis oil. The aim of the present study is to further elucidate possibilities and limitations of SEC in the analysis of (upgraded) pyrolysis oil.

\subsubsection{Separation mechanisms}

The separation mechanism of SEC is based on volume exclusion: for smaller molecules more pore volume is accessible, thus these molecules elute later than molecules with a larger size $e^{8,31}$. In practice secondary separation effects, e.g. hydrogen bonding with the 
mobile phase and/or adsorption with the column packing affect the basic separation mechanism. Hydrogen bond formation between the solvent (often THF) and the sample can lead to a lower elution time ${ }^{19,30}$, whereas interactions between the column packing and solute can lead to a longer retention time. The interactions between the column packing and solute is (partly) responsible for the lower than expected molecular weights as observed for, for example, aromatics ${ }^{11,12,30}$. Garcia-Perez et al. ${ }^{27}$ and Grienke and O'Conner ${ }^{11}$ point at a relation between the solvent polarity and the degree of interaction between the column packing and solute. Since the column used for pyrolysis oil analyses is usually a copolymer of styrene and di-vinyl benzene ${ }^{20}$, the affinity of non-polar compounds to the column packing is expected to increase as solvent polarity increases. A proper combination of solvent/mobile phase and column material should limit the secondary separation mechanisms as much as possible, although total elimination seems impossible. An ideal solvent fulfills the following criteria:

- Capable of dissolving the whole sample. A polar solvent is required to dissolve pyrolysis oil. For upgraded pyrolysis oil (HDO-oil) a less polar solvent can be used.

- Secondary interactions between the oil sample and solvent are minimal, i.e. a nonpolar solvent is required to minimize hydrogen bonding.

- Minimal interaction between the sample and column packing. A non-polar solvent is required to prevent sample/column interactions for the non-polar compounds especially the aromatics.

- The detector(s) should have a notably different sensitivity for the solvent phase than for the compounds in the sample to be analyzed.

As shown above, the solvent needs to fulfill contradictory requirements with respect to polarity. Although not perfectly fulfilling the aforementioned criteria, THF as mobile phase with styrene-divinylbenzene copolymer gels as column packing is frequently used $^{20}$. Recently Ringena et al. ${ }^{21}$ reported on two new SEC systems for lignin analysis using dimethyl sulfoxide/water/lithium bromide with a polyacrylate methacrylate copolymer as column material and dimethylacetamide/lithium chloride with modified silica bearing free $\mathrm{OH}$ groups as column material. Because our aim was the analysis of whole (upgraded) pyrolysis oil, in this study THF in combination with styrenedivinylbenzene copolymer was used.

\subsubsection{Molecular weight distribution}

With SEC it is possible to obtain (an indication of) the molecular weight distribution. In the final SEC output $\mathrm{W}(\log \mathrm{M})$ is shown as a function of $\log \mathrm{M}$. $\mathrm{W}(\log \mathrm{M})$ is defined as the slope of the graph in which the cumulative mass is plotted against the logarithm of the molecular weight $(\log \mathrm{M})$. This distribution, as given in eq. (1) can be obtained from the 
chromatogram $(f(v))$ and the calibration curve that relates the elution volume to the molecular mass (eq. (2)). In the conversion of the chromatogram (Figure 6.1A) to the molecular weight distribution (Figure 6.1B) the following steps are needed: (i) a baseline is drawn between two (numerically/manually) chosen points, (ii) peaks below this baseline are removed, (iii) an upper- and lower integration boundary are chosen (in Figure 6.1, base line points = integration boundaries), (iv) the elution volume is converted to $\mathrm{M}$ using the calibration curve (eq. (2)). In this step the chromatogram is mirrored, (v) the signal is converted to $\mathrm{W}(\log \mathrm{M})$ using eq. (1). The shape of the curve is not affected by this procedure, (vi) the area $\left(\int \mathrm{W}(\log \mathrm{M}) \mathrm{d} \log \mathrm{M}\right)$ under the curve is normalized to 1 .

$W(\log M)=C \cdot \frac{1}{\alpha} \cdot f(\mathrm{v})$

$\log M=C_{1}-C_{2} \cdot \mathrm{v} \quad$ with $\quad C_{2}=1 / C$

$\alpha$ is the response factor which relates the injected mass to the peak area in the chromatogram.

$$
\int_{\mathrm{v}_{1}}^{\mathrm{v}_{2}} f(\mathrm{v}) d \mathrm{v}=\alpha \cdot m
$$

The derivation of these equations are reported in Appendix 6A as well as the equations for the number average molecular weight $\left(M_{n}\right)$ and weight average molecular weight $\left(\mathrm{M}_{\mathrm{w}}\right)$. Two important assumptions in eq. (1) with respect to the SEC characterization of (upgraded) pyrolysis oil are:

1. For oil analyses a conventional calibration procedure is typically used to convert the elution volume to the molar mass ${ }^{15,19,20,27}$ (eq. (2)). It is assumed that this conversion applies uniformly to each compound present in (upgraded) pyrolysis oil. The validity of this assumption is discussed in section 6.3.2.

2. The response factor $\alpha$ as defined in eq. (1) is assumed to be compound and concentration independent. The validity of this assumption-implicitly used by many researchers in the field of (upgraded) pyrolysis oil ${ }^{14,17,22,27,28,30}$ is discussed in section 6.3.3.

Although the conversion of the chromatogram to the $\mathrm{M}_{\mathrm{w}}$-distribution seems simple, the analysis itself and interpretation must be done with great care. Artifacts related to the above mentioned assumptions in relation to (upgraded) pyrolysis oil will be shown in the following sections. 

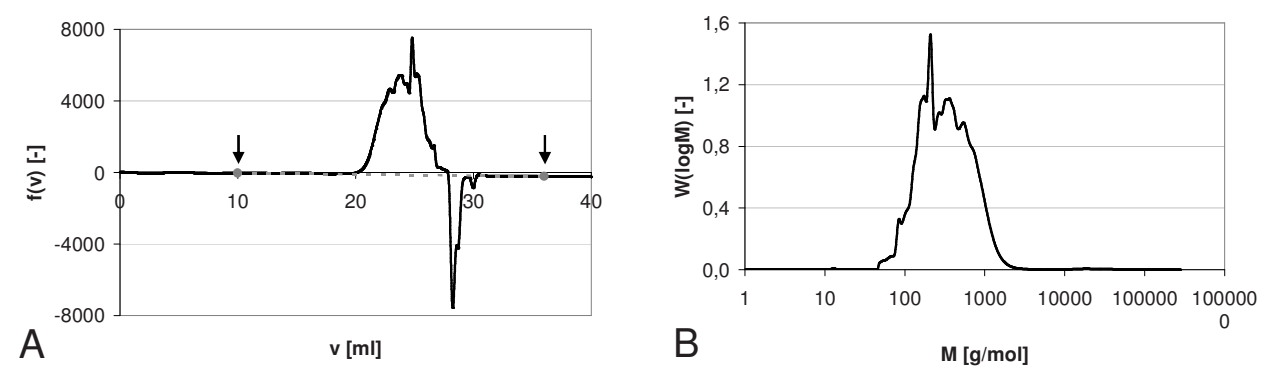

Figure 6.1 Conversion of chromatogram to molecular weight distribution A: chromatogram - - - = baseline - = both baseline point and integration boundary B: $\mathrm{M}_{\mathrm{w}}$-distribution

\subsection{Materials and methods}

\subsubsection{Instrumentation}

\section{SEC system}

The analysis was performed using a SEC system of the Agilent Technologies 1200 series consisting of a thermostatted autosampler (G1329A), degasser (G1322A), isocratic pump (G1310A), thermostatted column compartment (G1316A), ultra violet-detector (UVD) (G1314B), refractive index-detector (RID) (G1362A) and Agilent SEC data analysis software. The UV-detector was operated at $254 \mathrm{~nm}$. Most data reported in this chapter were obtained using the RI-detector, data obtained with the UV-detector are reported in section 6.4.3.

Tetrahydrofuran (THF, Sigma-Aldrich 34865, purity 99.9\%) was used as eluent (1 $\mathrm{ml} / \mathrm{min}$ ). A highly crosslinked polystyrene-divinylbenzene copolymer gel was used as column packing (Varian, PLgelMIXED-bed E). The system incorporated three columns placed in series $(7.5 \times 300 \mathrm{~mm}$, particle size $3 \mu \mathrm{m})$. During a typical analysis $20 \mu \mathrm{l}$ of sample was injected into the column. The column temperature was $40{ }^{0} \mathrm{C}$. Sample runs lasted $40 \mathrm{~min}$.

Polystyrene standards with a molecular mass between 162 and $29510 \mathrm{~g} / \mathrm{mol}$ were used for calibration. In this range and for these types of columns a linear relation exists between the elution time and the logarithm of the molecular mass ${ }^{32}$ (eq. (2)). It is important to point out that the SEC column is designed to separate molecules up to $30,000 \mathrm{~g} / \mathrm{mol}$ while molecular weights up to only $2000 \mathrm{~g} / \mathrm{mol}$ are observed in pyrolysis oil (Figure 6.1). So, the SEC system was operated at the lower end of the molecular weight range. 


\section{Additional analyses: Karl Fischer titration and H-NMR}

Two types of additional analyses were carried out to support/ validate the results obtained using SEC. Karl Fischer titration was used to determine the water content of pyrolysis oil (Metrohm 787 KFTitrino). 1H-NMR (Avance II Bruker $600 \mathrm{MHz}$ System using a 5mm TXI probe $1 \mathrm{H} / \mathrm{D}-13 \mathrm{C} / 15 \mathrm{~N}$ Z-GRD) was used to obtain an indication of the functional groups present in (upgraded) pyrolysis oil. Residual Solvent protons were used as an internal standard and chemical shifts are given relative to tetramethylsilane (TMS).

\subsubsection{Materials and preparation procedures}

Analyses were carried out with different types of (upgraded) pyrolysis oil and 16 model compounds. The idea was to choose model compounds with different functional groups representing (upgraded) pyrolysis oil. Compounds with molecular masses between 162 $\mathrm{g} / \mathrm{mol}$ and $2000 \mathrm{~g} / \mathrm{mol}$ were chosen. $162 \mathrm{~g} / \mathrm{mol}$ is the lower limit of the polystyrene calibration curve and molecules up to $2000 \mathrm{~g} / \mathrm{mol}$ are observed by SEC in pyrolysis oil. Furthermore, hydrocarbons representing two extremes with respect to hydrodynamic volume versus molecular mass ratio - poly aromatic hydrocarbons $(\mathrm{PAH})$ and alkanes were used. Despite the presence of nitrogen, which is typically present in pyrolysis oil in limited concentrations, compounds from a Fmoc-series were additionally used. This was done to be able to systematically study the influence of a change in functional group on SEC analysis results. The model compounds used in this study including their structure, molecular mass and purity are listed in Appendix 6B. The (upgraded) pyrolysis oils used in this study were:

(i) Pyrolysis oil (PO-oil).

The oil was produced by fast pyrolysis in a continuously operated fluidized bed reactor $\left(1 \mathrm{~kg} / \mathrm{h}\right.$ ) from pinewood (lignocel 9, Rettenmaier \& Sohne GmbH) ${ }^{6 \text {, (chapter }}$ $5,25,33$

(ii) Organic fraction PO-oil.

The pyrolysis oil from (i) was fractionated in a top and bottomphase by adding 50 wt $\%$ demi-water ${ }^{6}$. The bottom phase is called the organic fraction of PO-oil.

(iii) Aqueous fraction PO-oil.

The top phase from the procedure described in (ii) is called the aqueous fraction of PO-oil.

(iv) HDO-oil.

Hydrodeoxygenation is one of the processes used to upgrade pyrolysis oil to amore stable product with lower oxygen content ${ }^{7}$. In this process, pyrolysis oil reacts with hydrogen under high pressures (100-350 bars) and moderate temperatures $\left(250-400{ }^{\circ} \mathrm{C}\right)$. During HDO of pyrolysis oil phase separation occurs producing an aqueous phase and an oil phase (HDO oil). The HDO oil as used in this study was produced at the University of Twente. As feedstock for the 
production of HDO oil samples, pyrolysis oil produced by VTT from forest residue was used ${ }^{34}$.

(v) Aqueous Phase HDO-oil.

The aqueous phase as formed during the HDO process described in (iv).

(vi) HDO-oil of organic fraction PO-oil.

HDO-oil (iv) produced from only the organic fraction of pyrolysis oil (ii).

(vii) HDO-oil of aqueous fraction PO-oil.

HDO-oil (iv) produced from aqueous fraction pyrolysis oil (iii).

The samples for SEC analyses were prepared according to the following procedure, except otherwise reported. 10mg of the sample was dissolved per ml THF (SigmaAldrich 34865). Hereafter the solution was filtered (Whatman Spartan 13/0.2 RC, pore size $0.2 \mu \mathrm{m}$ ) prior to injection in the SEC column. All model compounds and (upgraded) pyrolysis oils dissolved completely in THF with the exception of glucose. Glucose was therefore first dissolved in water before following the sample preparation procedure as described above.

\section{3 $M_{w}$-distribution for (upgraded) pyrolysis oil}

\subsubsection{Calculation procedure}

For the conversion of the chromatogram to the $\mathrm{M}_{\mathrm{w}}$-distribution as described in section 6.1 it is necessary to choose two baseline points and two integration boundaries. The baseline points were chosen equal to the integration boundaries in Figure 6.1, however these do not need to be necessarily the same. If front and/or end tailing affect the $\mathrm{M}_{\mathrm{w}}$-distribution to a large extent, or THF degradation peaks are present (section 6.4.1) or if only certain areas of the chromatogram are of interest, it is even desirable to exclude part of the peak area in the chromatogram. For example, the low molecular mass fraction can be excluded if the only interest is to study the 'polymerized' products typically obtained during high temperature processing/upgrading of pyrolysis oil.

It is important to realize that SEC data which need to be compared which each other should always be processed according to the same calculation procedure. Baumberger et al. $^{20}$ found that variations could be reduced substantially between the different laboratories by applying the same calculation procedure to the rough data from the different laboratories. Furthermore, the complete molecular weight distribution contains more information than a single number representing the average molecular mass (eqs. (A.9) and (A.10); Appendix 6A) and its use is preferred when analyzing SEC results. More reasons for that will be given in sections 6.3.2 and 6.3.3. 


\subsubsection{Molecular weight values: the $\mathrm{x}$-axis}

The real molecular weight (Mreal) has been compared with the SEC results $\left(M_{n}\right.$ and $\left.M_{w}\right)$ for 14 model compounds (Appendix 6B). The result of the complete series is shown in Table 6.1. The model compounds were classified in three categories: (1) the measured molecular weight is at least $10 \%$ too small, (2) the measured molecular weight is at least $10 \%$ too large, (3) the measured and real molecular weight equals each other within $10 \%$. The classification (1-3) in Table 6.1 will be discussed using the two extremes: fluoranthene (polycondensed hydrocarbon (PAH) and eicosane (alkane). The results for these two entirely different molecules are shown in Figure 6.2. The measured molecular weight for fluoranthene is approximately four times too small, whereas the measured molecular weight for eicosane is more than 1.5 times higher than the real value. The deviations of the measured molecular weights to the real values can be explained by the differences between the model compounds and the polystyrene calibration standards. The separation mechanism is based on size exclusion (section 6.1) and the measured retention volume is converted to the molecular weight distribution curve using a conventional calibration procedure based on polystyrene samples (eq. (2)). Alkanes do have a higher ratio of hydrodynamic volume to molecular weight than polystyrene ${ }^{30}$. Based on the calibration curve of polystyrene they will elute earlier from the column than expected, resulting in an overestimation of their molecular weight. In contrast, PAH's do have a lower ratio of hydrodynamic volume to molecular weight than polystyrene which results in an underestimation of the molecular mass. In case of PAH's undesired adsorption effects are additionally expected to further increase the retention time and therewith result in an underprediction of the molecular weight as discussed in section 6.1. Adsorption effectsbecomevisible from tailing in the chromatogram in the $\mathbf{M}_{\mathrm{w}}$-distribution curve of fluoranthene (Figure 6.2).
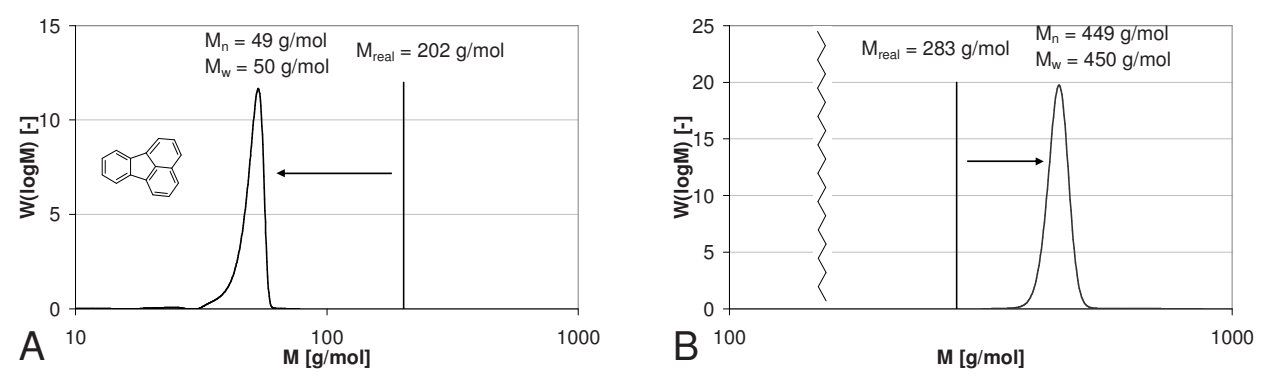

Figure 6.2 Real and measured values for $M_{n}$ and $M_{w}$. A: Fluoranthene B: Eicosane 
Table 6.1 Comparison of real and experimentally determined values of molecular weight for several model compounds.

\begin{tabular}{|c|c|c|c|c|}
\hline & $\begin{array}{l}\mathbf{M}_{\text {real }} \\
{[\mathrm{g} / \mathrm{mol}]}\end{array}$ & $\begin{array}{l}M_{n} \\
{[\mathrm{~g} / \mathrm{mol}]}\end{array}$ & $\begin{array}{l}\mathrm{M}_{\mathrm{w}} \\
{[\mathrm{g} / \mathrm{mol}]}\end{array}$ & Classification \\
\hline Fluoranthene & 202 & 49 & 50 & \multirow{6}{*}{$\begin{array}{l}\text { Category } 1 \\
\text { Underestimation }\end{array}$} \\
\hline Anthracene & 178 & 51 & 53 & \\
\hline Fmoc-His(Trt)-OH & 620 & 428 & 434 & \\
\hline Fmoc-His(Mtt)-OH & 634 & 441 & 448 & \\
\hline Fmoc-Asn(Trt)-OH & 597 & 522 & 525 & \\
\hline Fmoc-Gln(Trt)-OH & 611 & 539 & 541 & \\
\hline Citric acid & 192 & 320 & 324 & \multirow{4}{*}{$\begin{array}{l}\text { Category } 2 \\
\text { Overestimation }\end{array}$} \\
\hline Eicosane & 283 & 449 & 450 & \\
\hline Hexadecane & 226 & 344 & 345 & \\
\hline Fmoc-Glu(OtBu)-OH & 426 & 472 & 473 & \\
\hline Glucose & 180 & 197 & 199 & \multirow{3}{*}{$\begin{array}{l}\text { Category } 3 \\
\text { Accurate estimation }\end{array}$} \\
\hline Fmoc-D-Leu-OH & 353 & 374 & 375 & \\
\hline Fmoc-Asp(OtBu)-OH & 411 & 426 & 428 & \\
\hline Fmoc-Gly-OH ${ }^{\mathrm{a}}$ & 297 & 300 & 301 & $0.90<\mathrm{M}_{\mathrm{n}} / \mathrm{M}_{\text {real }}<1.10$ \\
\hline
\end{tabular}

${ }^{\mathrm{a}}$ Measured three times, maximum deviation $2 \mathrm{~g} / \mathrm{mol}$

Excluding secondary separation mechanisms (section 6.1); the molecular weight of compounds with a lower ratio of hydrodynamic volume to molecular weight than polystyrene (e.g. aromatics) is expected to be underestimated (category 1). For compounds with a higher ratio of hydrodynamic volume to molecular weight than polystyrene (e.g. alkanes) the molecular weight tends to be overestimated (category 2). The molecular weight of compounds with similar structures as polystyrene is predicted fairly accurately (category 3). Our results on the deviation from the conventional calibration curve are consistent with results obtained by other research groups ${ }^{10,15,27,30}$ It will be clear that it is not possible to select a single calibration standard which reflects the behavior of all the compounds present in (upgraded) pyrolysis oil. In general, the experimental SEC $\mathrm{M}_{\mathrm{w}}$-distribution thus will not reflect the absolute molecular masses or mass distribution for the compounds present in (upgraded) pyrolysis oil and can at the best be used to identify shifts in the molecular weight distribution.However, even then care should be taken because apparent changes in molecular mass (distribution) before and after a pyrolysis oil treatment (like HDO), might be caused by changes in chemical structure (ring formation/opening, deoxygenation) and not major changes in molecular mass (distribution). 


\subsubsection{Effect of refractive index and concentration: the y-axis}

$\mathrm{W}(\log \mathrm{M})$ is plotted on the $\mathrm{y}$-axes of the molecular weight distribution curve and is proportional to the RI-detector signal (eq. (1)). For the conversion of the chromatogram to the molecular weight distribution the software (suited for polymer characterization) assumes the response factor $(\alpha)$ to be compound and concentration independent (eq. (3)). However, the refractive index is compound dependent, making this assumption questionable $^{35}$. The validity of a constant $\alpha$-value was studied for model compounds and (upgraded) pyrolysis oil.

SEC chromatograms were determined for thirteen model compounds for concentrations between 1 and $34 \mathrm{mg} / \mathrm{ml}$. The RID response factor (eq. (3)) can be obtained by plotting the total peak area $\left(\int \mathrm{f}(\mathrm{v}) \mathrm{dv}\right.$ in chromatogram) versus the total injected mass. The peak area was - per compound - indeed linearly dependent on the injected mass. However, the RID response factor was strongly compound dependent and differed up to a factor 10 (Table 6.2). The highest $\alpha$-value was found for anthracene and the lowest for hexadecane. Compounds containing more polarizable groups (e.g. aromatic rings) will normally have higher refractive indices than compounds containing less polarizable groups (e.g. oxygen atoms or alkyl groups $)^{36}$. As a consequence, the peak heights in the chromatogram of (upgraded) pyrolysis oil must be influenced by the type of compound (e.g. aromaticity) and cannot automatically be translated into an $\mathbf{M}_{\mathrm{w}}$-distribution as done by the software.

Tabl 6.2 Response factor $(\alpha)$ for different model compounds

\begin{tabular}{|l|l|l|}
\hline & $\begin{array}{c}\alpha \\
{\left[\mathrm{m}^{3} / \mathrm{g}\right]}\end{array}$ & $\frac{[\alpha]_{\text {component }}}{[\alpha]_{\text {hexadecane }}}[-]$ \\
\hline Hexadecane & 30 & 1,0 \\
\hline Eicosane & 41 & 1,4 \\
\hline Citric acid & 85 & 2,8 \\
\hline Anthracene & 307 & 10,2 \\
\hline Fluoranthene & 292 & 9,7 \\
\hline Fmoc-Asp(OtBu)-OH & 153 & 5,1 \\
\hline Fmoc-Glu(OtBu)-OH & 146 & 4,9 \\
\hline Fmoc-D-Leu-OH & 171 & 5,7 \\
\hline Fmoc-His(Mtt)-OH & 203 & 6,7 \\
\hline Fmoc-His(Trt)-OH & 218 & 7,2 \\
\hline Fmoc-Gly-OH & 167 & 5,5 \\
\hline Fmoc-Gln(Trt)-OH & 205 & 6,8 \\
\hline Fmoc-Asn(Trt)-OH & 213 & 7,1 \\
\hline
\end{tabular}




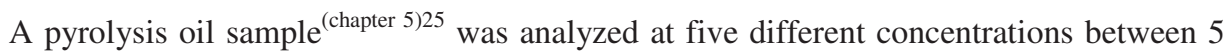
and $23 \mathrm{mg} / \mathrm{ml}$. The chromatograms obtained between 18 and $25.8 \mathrm{ml}$ elution volume are plotted in Figure 6.3A. The peaks which appear above $25.8 \mathrm{ml}$ were excluded since THF degradation products are expected to appear in this region and will significantly affect the chromatograms for especially low concentrated samples (see section 6.4.1). Water is mainly responsible for the negative detector response (section 6.4.4) and this peak was always excluded while composing the $\mathrm{M}_{\mathrm{w}}$-distribution. The (average) response factor was therefore expressed on dry oil basis. Figure 6.3A shows that the peaks within the SEC chromatogram remained at the same x-values, their location thus being independent on concentration. This indicates that the column was capable of separating the pyrolysis oil sample in a similar way, so the extent of a possible secondary separation mechanism (section 6.1) did not noticeably change with concentration within the concentration range used. Furthermore, the peaks would have shifted towards lower elution volumes for an overloaded column, since too few pores would be available for the small molecules. Also, Johnson and Chum ${ }^{30}$ observed no change in peak position for pyrolysis oil samples as a function of concentration ( $3 \mu \mathrm{g} / \mathrm{ml}-4 \mathrm{mg} / \mathrm{ml}$ ). A larger fraction of high molecular weight compounds (corresponding to lower elution volumes) was observed by Greinke and $\mathrm{O}^{\prime} \mathrm{Conner}^{11}$ for petroleum pitch when they injected amuch larger amount of sample (90 $\mathrm{mg}$ ) into the column. Although the shape of the chromatogram seems to be changing with concentration; the (normalized) molecular weight distribution curves are exactly the same (Figure 6.3B). Similar (normalized) molecular weight distribution curves are only obtained if the peak area of all the compounds present in the pyrolysis oil sample is linearly dependent upon the concentration (and mass). Similar to our results, Baumberger et al. ${ }^{20}$ did not observe an influence of concentration $(0.3-1 \mathrm{mg} / \mathrm{ml})$ on the normalized $\mathrm{M}_{\mathrm{w}}$-distributions. These findings do not indicate that the $\alpha$-values of the individual compounds/molecular weight regions as present in a pyrolysis oil sample are identical. Therefore, different types of oil samples were analyzed to identify a possible variation of the overall $\alpha$-value with the type of sample, but also a variation of $\alpha$-value within the same sample.
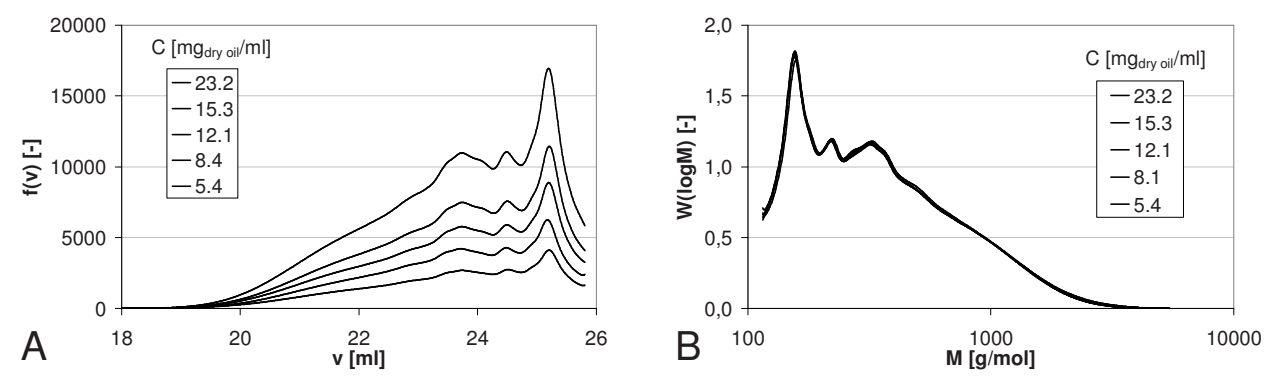

Figure 6.3 Effect of concentration for a Pyrolysis Oil (24.7 wt\% water) sample A) Chromatogram between an elution volume of 18 and $25.8 \mathrm{ml}$. B) $\mathrm{M}_{\mathrm{w}}$ - distribution calculated from SEC 
Two pyrolysis oils produced under different process conditions ${ }^{6,(\text { chapter 5)25,33 }}$, three HDOsamples $^{7}$ (obtained from pyrolysis oil, the aqueous and organic phase from pyrolysis oil, respectively) and the aqueous phase obtained in the HDO process were analyzed at concentrations between 3 and $27 \mathrm{mgdry}$ oil $/ \mathrm{ml}$ (see section 6.2 .2 for specifications). The $\mathrm{M}_{\mathrm{w}}$-distribution curves for pyrolysis oil and the upgraded oils are shown in Figure. 6.5A and 6.4A, respectively. Figure. 6.4B shows that, for each oil, the integrated peak area is again proportional to the injected mass, indicating (per oil) a concentration independent $\alpha$-value. The $\alpha$-value of pyrolysis oil was approximately $30 \%$ lower than that of the HDO oil. Based on the severe upgrading conditions during HDO a considerable change in chemical structure/properties can be expected ${ }^{7}$ (see also Figure 6.10, section 6.4.3), which makes the observed change in overall response factor $(\alpha)$ seem rather small. HDO oils prepared from whole pyrolysis oil, the aqueous fraction and the organic fraction, respectively, show somewhat larger differences in $\alpha$-value. The $\alpha$-value of the HDO oil prepared from the organic fraction from pyrolysis oil $\left(\alpha=121 \mathrm{~m}^{3} / \mathrm{g}\right)$ is higher than that of HDO oil from whole pyrolysis oil $\left(\alpha=104 \mathrm{~m}^{3} / \mathrm{g}\right)$ and this one is again higher than the HDO oil prepared from the aqueous fraction $\left(\alpha=89 \mathrm{~m}^{3} / \mathrm{g}\right)$. This trend might be explained by the presence of less lignin derived compounds (less polarizable) in the HDO oil from the aqueous phase as compared to the HDO oil from the organic phase. Figure 6.4A shows the relatively high content of low molecular mass components in the aqueous phase remaining after HDO of whole pyrolysis oil. The response factor $(\alpha)$ of this aqueous fraction is much lower ( factor 3 ) compared to the response factors obtained for the various oils. This might again be explained by a much lower concentration of lignin derived compounds. An additional explanation for the low $\alpha$ value for this aqueous HDO phase could be the presence of a higher concentration of compounds responsible for negative chromatographic peaks (other than water). After HDO, low molecular mass compounds like acetic acid, methanol and ethanol mostly end up in this aqueous phase and upon SEC yield negative peaks.
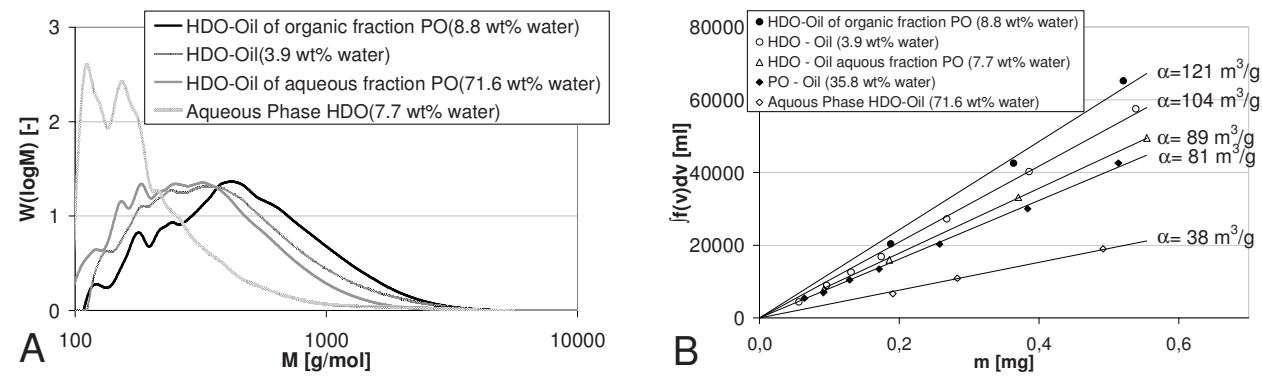

Figure 6.4 Effect of concentration for different oil samples $A$ : $M_{w}$-distributions $(18-26 \mathrm{ml}) \mathrm{B}$ : $\alpha$-values (eq. 3) 

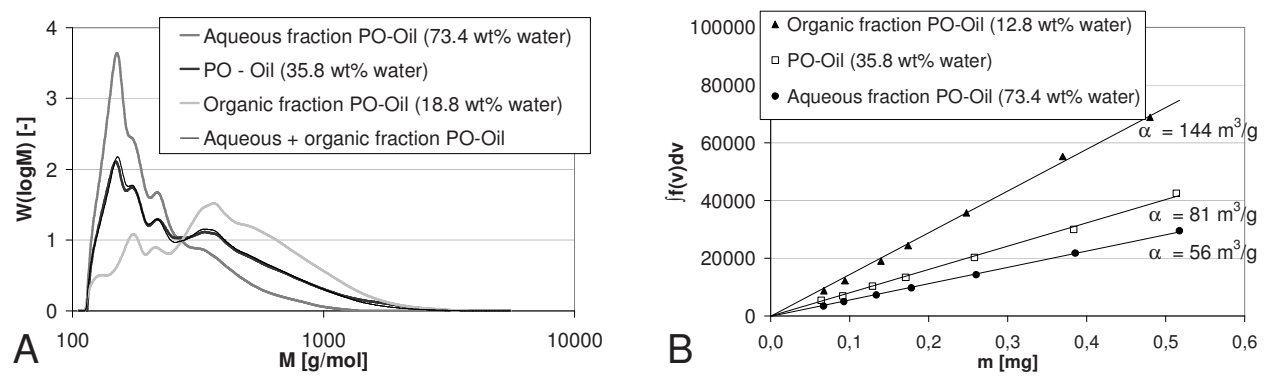

Figure 6.5 Effect of concentration for fractionated pyrolysis oil A: $\mathrm{M}_{\mathrm{w}}$-distribution $(18-26 \mathrm{ml}) \mathrm{B}: \alpha$ values (eq. 3)

As indicated, differences in $\alpha$-value as observed for the analyzed (upgraded) pyrolysis oil samples are also expected to be present within the same sample. If so, this would limit the use of the peak height/area as a relative measure of the concentration of a specific molecular weight range within the $\mathrm{M}_{\mathrm{w}}$-distribution. To explore this possible variation of the response factor $(\alpha)$ over the molecular weight range in pyrolysis oil, additional SEC analyses were carried out. In these analyses, fractions that were obtained from whole pyrolysis oil were used. A pyrolysis oil sample (35.8 wt\% water) was separated in an aqueous top and an organic bottom phase by adding $50 \mathrm{wt} \%$ water $^{6} .27 \mathrm{wt} \%$ of the total organics was transferred to the organic bottom phase while the remaining organics were in the aqueous top phase. The molecular weight distribution curves of the different phases and that of the original pyrolysis oil sample are plotted in Figure 6.5A. The high molecular weight compounds are mainly present in the organic phase while the aqueous phase contains the larger part of the low molecular weight compounds. Figure 6.5A shows that proportional (weight fraction based) summation of the $\mathrm{M}_{\mathrm{w}}$-distribution curves obtained for both phases yields the $\mathrm{M}_{\mathrm{w}}$-distribution curve of the original pyrolysis oil sample. This summation shows that no compounds were lost during the phase separation and two overall homogenous phases were obtained. SEC analyses were performed on the two phases and the original pyrolysis oil sample at seven different concentrations, ranging from 3 to $26 \mathrm{mg}$ dry oil $/ \mathrm{ml}$ THF (Figure 6.5B). The organic phase had a RID response factor $(\alpha)$ which was nearly a factor 3 higher than that of the aqueous phase (based on dry sample). It is known that the organic fraction of pyrolysis oil consists to a considerable extent of lignin derived material ${ }^{37}$, which is rich in aromatic structures. Aromatic groups are more polarizable and are probably the cause of the higher RID response factor for the organic phase as compared to the aqueous phase. This clearly shows that the height/area of the peaks within the same chromatogram cannot be used to derive quantitative information on the relative concentrations. In this specific case, the amount of high molecular weight compounds is expected to be much lower than can be deduced from the height/area in the $\mathrm{M}_{\mathrm{w}}$-distribution curve of the whole pyrolysis oil sample. It should be noted that these intra-sample differences in RID response factor $(\alpha-$ 
value) are much higher than the inter-sample differences in overall $\alpha$-value as observed for pyrolysis oils and HDO oils, but similar to the differences in $\alpha$-value observed for HDO-oil and the produced aqueous phase in the HDO process (Figure 6.4).

In literature on pyrolysis oil (upgrading) only minor attention is paid to the meaning of the $\mathrm{y}$-axes $(\mathrm{W}(\log \mathrm{M}))$. Many researchers who are analyzing (upgraded) pyrolysis oil samples (implicitly) assume the $\alpha$-values to be compound/oil independent and use the height of the peaks as an indication of concentration ${ }^{15,18,24,27,28,30}$ Although in a different research field, current results are consistent with the results reported in the review of Atgelt and Gouw ${ }^{12}$ on SEC in petroleum analysis. They also briefly mention the variation of the refractive index detector response with the type of material. The experimental results in this section clearly show that the assumption that the RID response factor ( $\alpha$ in eqs. (1) and (3) is compound independent is not true. The heights $\backslash$ areas of the peaks in a (upgraded) pyrolysis oil SEC chromatogram (and thus also $\mathbf{M}_{\mathrm{w}}$-distribution) are influenced by the functionality of the compounds (e.g. polarizability) and do not only eflect the concentration. It is not possible to differentiate whether a small peak represents a trace compound with a large refractive index or a major compound with a refractive index very similar to that of the solvent. Valuable information can be obtained when comparing the height of the peaks at a certain $\mathrm{M}_{\mathrm{w}}$ of (upgraded) pyrolysis oil samples provided that the oils (are expected to) have a similar composition. However, comparing the values on the $\mathrm{y}$-axis $(\mathrm{W}(\log \mathrm{M}))$ for oils obtained at totally different process conditions, (e.g. pyrolysis oil before and after upgrading) or the height of peaks within the same diagram but at different molecular weights must be done with great care.

\subsection{Features and pitfalls of SEC analysis for (upgraded) pyrolysis oil}

\subsubsection{Potential artefacts due to THF peroxide peaks}

THF degrades in the presence of air (oxygen) to peroxides ${ }^{38}$ and the resulting peak should be excluded from data interpretation. In our SEC chromatograms a positive peak at 26 $\min (\sim 100 \mathrm{~g} / \mathrm{mol})$ appeared and the area of this THF degradation peak increased as a function of THF storage time (see Figure 6.6). Besides this positive peak, negative THF degradation peaks appear above 26 min which are normally excluded when constructing the $\mathrm{M}_{\mathrm{w}}$-distribution curves (section 6.1). 


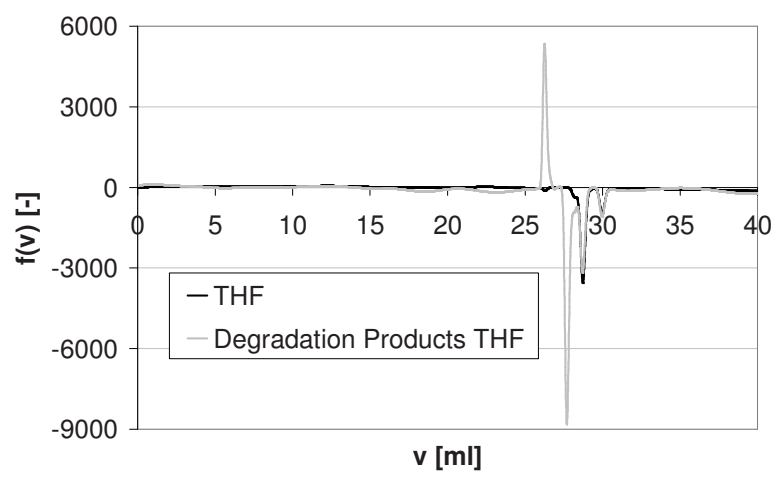

Figure 6.6 Blanks of respectively fresh THF and THF with degradation products after $>2$ months storage. The negative peaks above 26 minutes are normally excluded from data interpretation (see section 6.1).

\subsubsection{Column fouling and aging}

One pyrolysis oil sample was analyzed seven times to measure short term reproducibility. The calculated average molecular weights including their standard deviations for $M_{n}$ and $\mathrm{M}_{\mathrm{w}}$ were, respectively, $199 \pm 1.7$ and $302 \pm 2.1 \mathrm{~g} / \mathrm{mol}$. This indicates good short term reproducibility of the pyrolysis oil SEC analyses. It should be noted that these $M_{n} / M_{w}$ values and their standard deviations were just used to measure short time SEC reproducibility and do not represent the real values (section 6.3). Similar short term reproducibility was obtained for the model compounds.

It was not possible to carry out long term reproducibility tests on pyrolysis oil due to its intrinsic instability upon storage ${ }^{4}$. Therefore, long term reproducibility was determined using model compounds. A first indication on the change of the column performance over time can be obtained from the polystyrene calibration curves (eq. (2)). The calibration curves were constructed repeatedly within a one year period. Approximately 1100 samples were analyzed in this time period. The slope of the polystyrene calibration curves decreased over time $(3 \%)$ while the intercept increased $(1 \%)$. The sum of both shifts indicates that polystyrene molecules are eluting earlier over time. This net effect is illustrated in Figure 6.7 for three different molecular weights of polystyrene. 


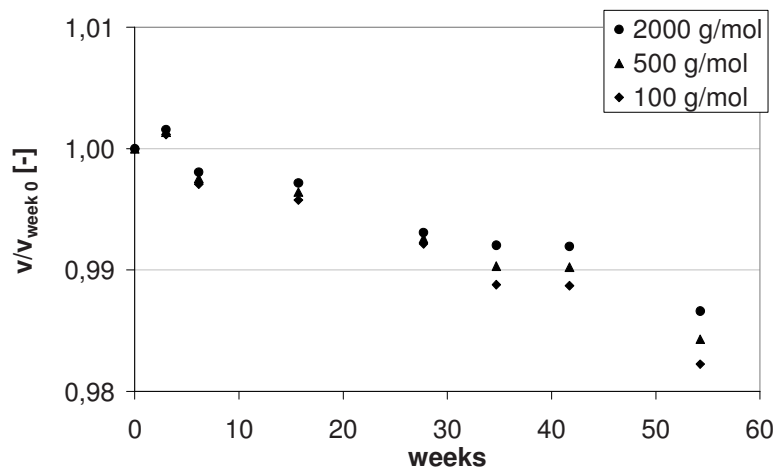

Figure 6.7 Relative elution volume of polystyrene calibration samples as a function of time.

The effect of column fouling was studied more thoroughly by following the shift of the peak for several model compounds over prolonged time. The results for eicosane, Fmoc$\mathrm{Glu}(\mathrm{OtBu})-\mathrm{OH}$ and a $5 \mathrm{wt} \%$ glucose in water solution are plotted in Figure 6.8. The chromatogram is plotted in the figures in the left column (A) while the $\mathrm{M}_{\mathrm{w}}$-distribution (based on regular recalibration with polystyrene) is plotted in the figures in the right column (B). The differences between the two columns show to what extent the polystyrene calibration procedure is able to correct for the peak shifts of the unconverted detector signals. In Figure 6.8A, it can be seen that the unconverted detector signals of the three compounds shift over time in a different way: water and glucose are eluting later while eicosane and Fmoc- $\mathrm{Glu}(\mathrm{OtBu})-\mathrm{OH}$ are eluting earlier. The change in polystyrene calibration curve is not able to correct for these different shifts. This is shown in the Figure 6.8B. Deterioration of the column performance over time does not have the same effect on compounds with different functional groups. This will basically result in different measured $\mathrm{M}_{\mathrm{w}}$-distribution curves of the same pyrolysis oil sample over time since pyrolysis oil consists of a complex mixture of oxygenated compounds.

Besides the position of the peak the theoretical number of plates $(\mathrm{N})$ can be used as a parameter to follow the change in column efficiency over time as well (see eq. (4) $)^{39}$.

$N=\frac{L}{H}=16\left(\frac{t_{R}}{W}\right)^{2} \quad$ (a) $\quad H=\frac{\sigma^{2}}{L}$

The theoretical number of plates belonging to the chromatograms plotted in Figure 6.8 is reported in Table 6.3. The change of the column efficiency over time is compound dependent, but in general a slight decrease is observed. 


\section{Chapter 6}
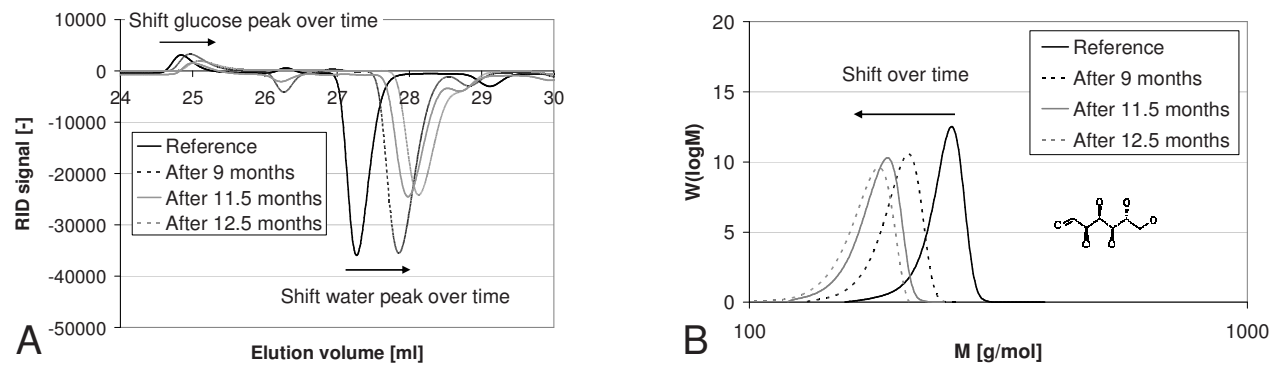

$5 \mathrm{wt} \%$ glucose in water
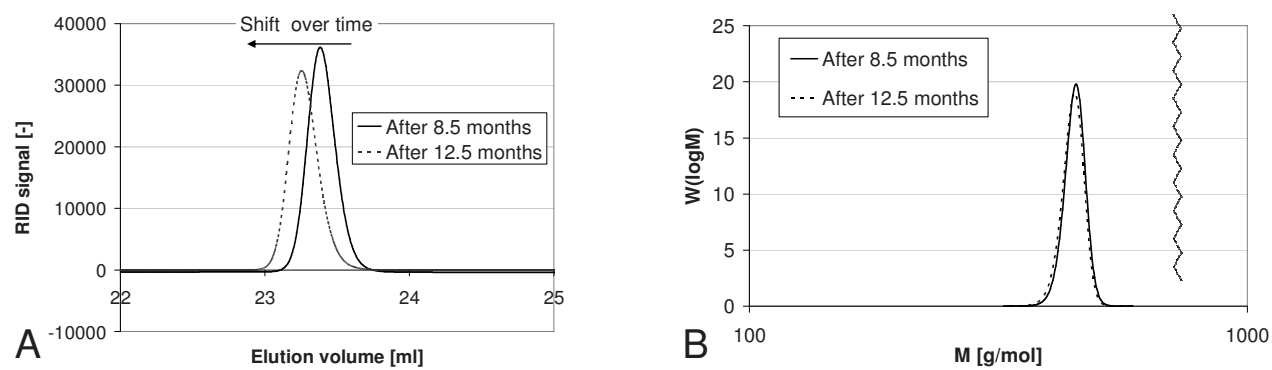

Eicosane
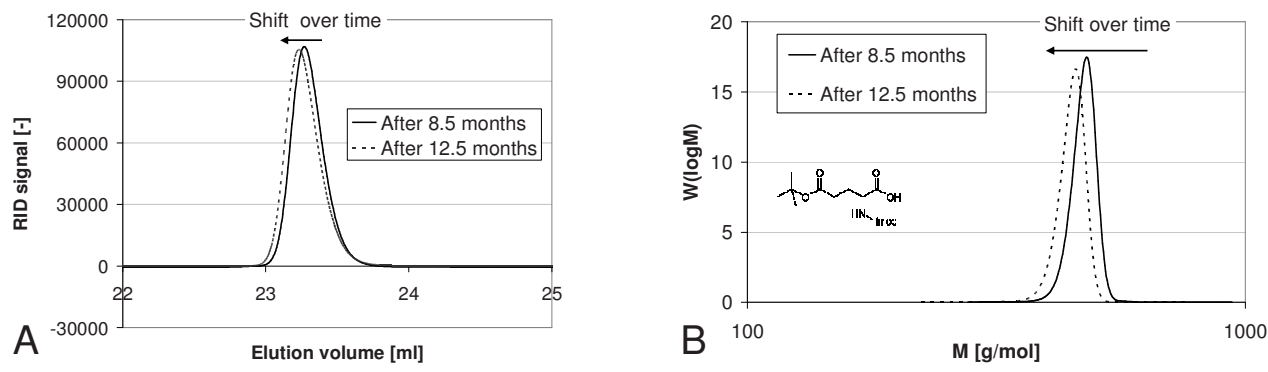

\section{Fmoc-Glu(OtBu)-OH}

Figure 6.8 Column fouling and aging SEC column for several model compounds A: Chromatogram B: $\mathrm{M}_{\mathrm{w}}$-distribution based on recalibration with polystyrene. (reference= moment when SEC system was taken in use)

Table 6.3 Change of column efficiencies over time

\begin{tabular}{|l|l|l|l|l|l|l|l|l|}
\hline Compound & \multicolumn{3}{|l|}{ Glucose } & \multicolumn{2}{l|}{ Eicosane } & \multicolumn{2}{l|}{ Fmoc-Glu(OtBu)-OH } \\
\hline Analyzed after [months] & 0 & 9 & 11,5 & 12,5 & 8,5 & 12,5 & 8,5 & 12,5 \\
\hline N [-] & $8 \cdot 10^{3}$ & $6 \cdot 10^{3}$ & $6 \cdot 10^{3}$ & $6 \cdot 10^{3}$ & $9 \cdot 10^{3}$ & $8 \cdot 10^{3}$ & $7 \cdot 10^{3}$ & $7 \cdot 10^{3}$ \\
\hline
\end{tabular}


The change of column performance over time with respect to peak position and column efficiency is most probably due to column fouling caused by irreversible adsorption of specific compounds (e.g. aromatics, see section 6.1). As a consequence, (upgraded) pyrolysis oil samples that are compared which each other should be analyzed within a limited time span and on the same system. Because column aging caused different effects per compound, recalibration of the column with polystyrene standards is not able to correct for long term column aging. The aging of the column should be monitored, e.g. with a mixture of model compounds representative of the samples to be analyzed: this should help in deciding if it is necessary to change (one of) the columns. The criteria need to be chosen based on the requirements related to accuracy/reproducibility.

\subsubsection{UVD/RID ratio linked to chemical structure}

Next to the standard RI-detector the SEC system was equipped with a UV-detector. The RI-detector is a universal detector for all compounds while the UV-detector (operated at $254 \mathrm{~nm}$ ) enabled selective detection of the aromatic and unsaturated conjugated compounds. Using both detectors enables the differentiation of compounds on the basis of their chemical structure in addition to molecular weight. Williams and Taylor ${ }^{15}$ reported a link between the ratio of the UVD and RID ( $\left.\int U V D d v / \int R I D d v\right)$ and the aromaticity for pyrolysis oils from tire waste. In their case they linked this ratio exclusively to the aromaticity, and not to the conjugated double bond content.

The possibility of using the ratio of the UVD and RID response to estimate the aromatic and conjugated double bond content was studied by first comparing the integrated results obtained by both detectors for some simple model compounds (( $\left.\int U V D d v / \int R I D d v\right)$. The model compounds without an aromatic group or conjugated double bond did have a negligible UV-detector response while the compounds containing such groups did show a response.

The same method was applied for different pyrolysis oil (derived) samples: a pyrolysis oil

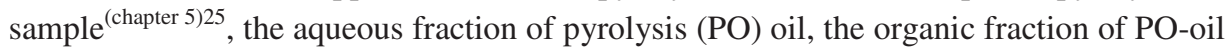
and a HDO oil sample ${ }^{7}$. The results are plotted in Figure. 6.9A. The organic phase of POoil has a higher $\int U V D d v / \int R I D d v$ ratio than PO-oil itself, and PO-Oil has a higher $\int U V D d v / \int R I D d v$ ratio than the aqueous fraction of PO-oil. This result is expected, because the organic fraction of PO-oil is known to contain the largest fraction of aromatic lignin fragments ${ }^{37}$. The ratio of the UVD and RID response is lower for the HDO sample compared to the pyrolysis oil samples. This would indicate a lower aromatic and conjugated double bond content for HDO. This was validated using H-NMR on these oils. The classification suggested by Ingram $^{28}$ et al. (see Figure 6.10 upper left) was used to interpret the H-NMR spectra in terms of functional groups. In Figure 6.10, it can be 
seen that also the H-NMR results suggest that the HDO oil contains less aromatics/conjugated double bonds (and more aliphatic like structures). This suggests that the $\int U V D d v / \int R I D d v$ ratio can indeed be used to obtain an indication of the relative aromaticity and conjugated double bond content for (upgraded) pyrolysis oil.

In the results above the integration boundaries covered the entire positive chromatogram area, while it is also possible to calculate the ratio of the UVD and RID response for different parts of the chromatogram. In Figure 6.9B, the ratio of the UVD and RID response is plotted for two molecular weight ranges of pyrolysis oil (100-460 and 460$2000 \mathrm{~g} / \mathrm{mol}$, respectively). The high molecular weight range has a higher UVD/RID ratio than the low molecular weight range, which would indicate that this range has a higher content in conjugated double bonds and aromaticity (expected to originate to a large extent from lignin).
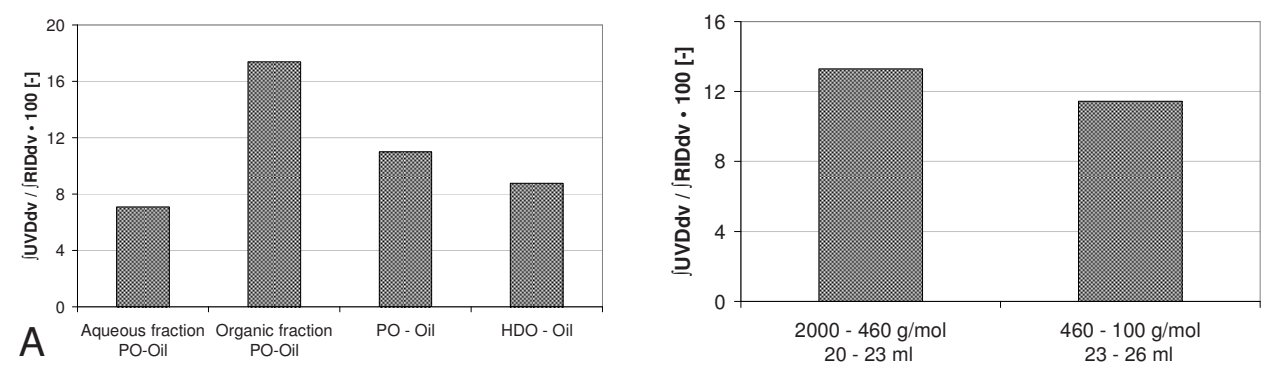

Figure 6.9 $\int \mathrm{UVdv} / \int \mathrm{RIDdv}$ ratio. Ratio is positively linked to aromatic and conjugated double bond content A: different oil samples B: two SEC fractions of pyrolysis oil.

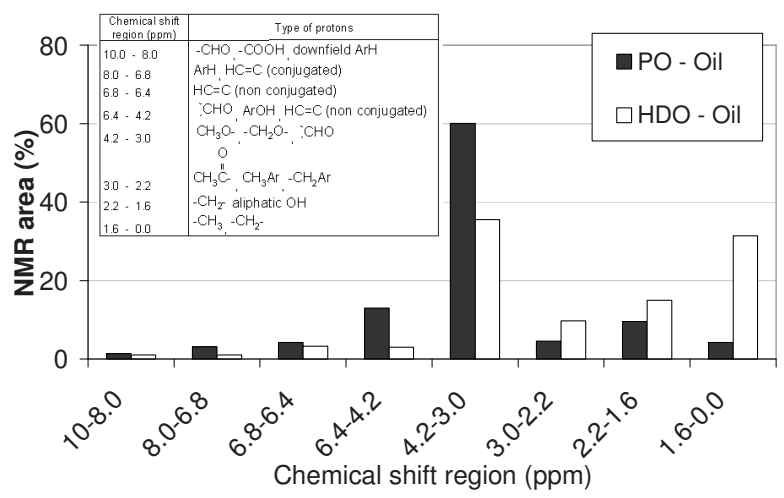

Figure 6.10 H-NMR results for (upgraded) pyrolysis oil interpreted by Ingram's method ${ }^{28}$ (water present between 4.2 and 3 ppm, water content HDO oil lower than that of pyrolysis oil). 
The RID response factor is related to the polarizability (section 6.3.3) and the $\int U V D d v / \int R I D d v$ ratio to the aromatic and unsaturated conjugated compounds. Both factors are thus related to the aromaticity to some extent and a mutual correlation might exist. For model compounds, the $\int U V D d v / \int R I D d v$ ratio and RID response factor (section 6.3.3) both increase with aromaticity of the sample. The same phenomenon can also be observed for pyrolysis oil fractions (Figure. 6.5 and 6.9A). However, this similarity was not found when comparing the results for PO-oil and HDO-oil. The HDO oil has a lower $\int U V D d v / \int R I D d v$ than pyrolysis oil, suggesting a lower level of aromaticity which is confirmed by H-NMR analysis (Figure 6.10). In contrast, the RID response for HDO-oil was slightly higher than that of pyrolysis oil. Apparently, there is no general relationship between RID response and the $\int U V D d v / \int R I D d v$ ratio. In this specific case, the relatively low response factor for pyrolysis oil probably might be related to the high level of acids that is present in pyrolysis oil (acetic and formic acid $\sim 6 \mathrm{wt} \%^{2}$ ) but far less in HDO oil ${ }^{40}$. These low molecular weight acids yield negative peaks in a SEC chromatogram ${ }^{35}$ (section 6.4.4) and are thus excluded in the calculation of the RID response factor of pyrolysis oil.

\subsubsection{Negative peak area linked to water content}

In Figure 6.1, it can be seen that negative peaks are typically present in the chromatogram. These peaks are eliminated when converting the measured data to the molecular weight distribution, which means that the information in the $\mathrm{M}_{\mathrm{w}}$-distribution plot is actually decreased with respect to the original chromatogram. Negative peaks occur for compounds with a lower refractive index than that of the solvent/eluent. For THF these molecules include for example paraffins (up to $\mathrm{C}_{9} \mathrm{H}_{20}$; paraffins ${ }^{29}$ only present in pyrolysis oil in low concentrations), small acids, methanol and water ${ }^{35}$, the latter being present up to $\sim 30 \%$ in pyrolysis oil. The observed chromatogram in the low molecular weight range ( $\sim 50$ to $150 \mathrm{~g} / \mathrm{mol})$ can thus very well be the composite of the simultaneous elution of components with a negative and positive RID response.

The water content of (upgraded) pyrolysis oil is normally determined using Karl Fischer titration (typically $1 \mathrm{ml}$ of pyrolysis oil is required). The applicability of SEC to determine the water content of (upgraded) pyrolysis oil was determined by making a parity plot of the negative peak area (between 27.8 and $29.5 \mathrm{~min}$ ) versus the water content measured by Karl Fischer titration (Figure 6.11B). A curve for the negative peak area versus known demi-water concentrations (in THF) was constructed as well and used as calibration curve (Figure 6.11A). The average absolute overestimation of the water content for the HDO and pyrolysis oil samples was $4.3 \mathrm{wt} \%$. This difference is most probably caused by the presence of other compounds than water with a lower refractive index than THF and eluting close to water. To illustrate this, methanol was injected into the column: The 
negative peak area of methanol between 27.8 and $29.5 \mathrm{~min}$ is plotted in Figure 6.11B as well. It can be seen that the RI-detector is much more sensitive to methanol than to water (higher absolute response factor). If methanol, or any other component eluting at the same time as water and having a high RID response, is present in the sample it can thus cause an error in the absolute prediction of the water content. In general it seems that the negative peak area can be used to estimate and identify changes in the water content of different oil samples.
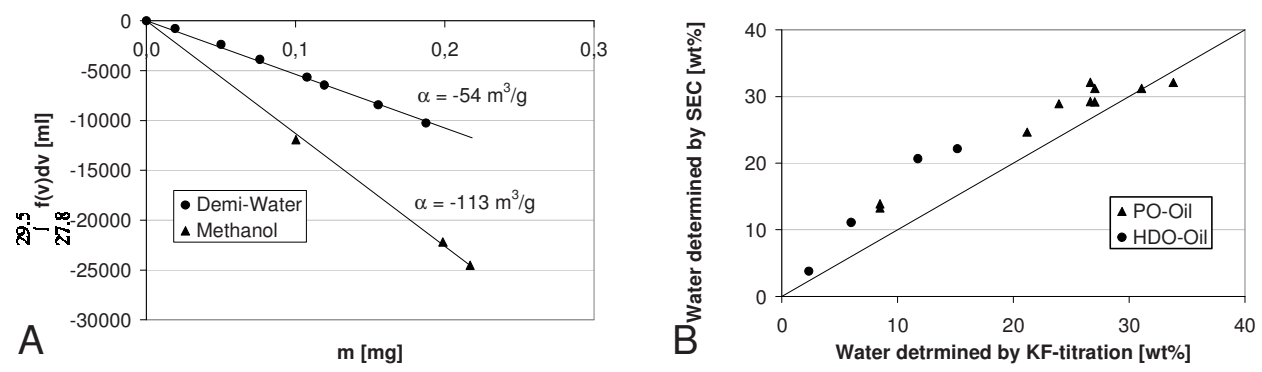

Figure 6.11 Determination of water content by SEC. A: a-values, demi-water curve used for calibration B: parity plot

\subsection{Conclusions}

The absolute $\mathrm{M}_{\mathrm{w}}$-distribution, $\mathrm{M}_{\mathrm{n}}$ and $\mathrm{M}_{\mathrm{w}}$ of (upgraded) pyrolysis oil cannot be obtained using SEC. In the conversion procedure of the chromatogram to the $\mathrm{M}_{\mathrm{w}}$-distribution, several assumptions have to be made, which are fundamentally erroneous when applied to (upgraded) pyrolysis oil. These assumptions are both related to the conversion of (elution volume tomolecular weight; $\mathrm{x}$-axis) and the (RID signal to $\mathrm{W}(\log \mathrm{M})$; $\mathrm{y}$-axis).

- Elution volume to molecular weight: The prediction of the absolute molecular weight values is not accurate, because the system is calibrated using one compound (polystyrene in our case) while (upgraded) pyrolysis oil consists of a wide variety of (oxygenated) compounds with different non-ideal behavior in the separation system. The SEC measured molecular weight of molecules with a small molecular size (in relation to molecular weight, e.g. aromatics) is too low, while for compounds with a large molecular size (in relation to molecular weight, e.g. alkanes) it is too high. Because pyrolysis oil contains so many different compounds a uniform correction is not possible. In addition, secondary separation effects caused by hydrogen bonding with the mobile phase and adsorption to the column packing can lead to over and underestimation of the molecular weights, respectively. 
- RID signal to $\mathrm{W}(\log \mathrm{M})$ : The conversion of RID response to $\mathrm{W}(\log \mathrm{M})$ is based on the assumption of a compound independent and linear response to the injected mass (related to concentration). While the latter is true for the model compounds and the (upgraded) pyrolysis oil samples studied in this work, the former has shown to be not true. The response factors are influenced by the functionality of the compounds (e.g. polarizability) and thus do not only reflect the concentration. The intra-sample difference in the RID response factor $(\alpha)$ for pyrolysis oil (low and high molecular weight range) was found to be a factor 3. Inter-sample differences in . for pyrolysis oil and HDO oil were found to be relatively small ( $\sim 30 \%$ difference in overall $\alpha$ value).

As a consequence, SEC should not be used to analyze just a single sample. We recommend to use SEC to compare (upgraded) pyrolysis oil samples preferably of similar composition, like e.g. pyrolysis oils produced using incremental changes in process conditions. Instead of the $\mathrm{M}_{\mathrm{w}}$-distribution curve, also the chromatogram can be used directly to prevent misinterpretation of the SEC results. The advantage of this method is that the data have not been subjected to any conversion (with required assumptions). When large differences in chemical composition are present or can be expected - e.g. in the comparison of crude pyrolysis oil and HDO oil, great care should be taken in drawing conclusions from either the $\mathrm{M}_{\mathrm{w}}$-distribution or the chromatogram. Furthermore, it is important to note that when analyzing/comparing multiple samples, the analyses itself should be carried out under the same analytical conditions (e.g. same calculation procedure, perform analyses on the same SEC system within a limited time span).

This work has further shown that (i) the ratio of the UVDand RID response ( $\left.\int U V D d v / \int R I D d v\right)$ can be used as an indication of the sum of the relative aromaticity and conjugated double bond content for (upgraded) pyrolysis oil; (ii) the negative peak area can be used to estimate the water content of (upgraded) pyrolysis oil samples.

To our opinion, SEC can supply valuable information when applied to (upgraded) pyrolysis oil, as long as the user is aware of the pitfalls. We believe that SEC in combination with additional analytical technique(s) (e.g. NMR, FTIR, HPLC, viscosity; applied on whole sample or SEC fractions) will give new insights into the characteristics of (upgraded) pyrolysis oil. 


\section{Symbols}

\begin{tabular}{ll}
\multicolumn{2}{l}{ Abbreviations } \\
GPC & Gel Permeation Chromatography \\
HDO & Hydro De Oxygenation \\
PAH & Poly aromatic hydrocarbons \\
PO & Pyrolysis Oil \\
RID & Refractive index detector \\
SEC & Size Exclusion Chromatography \\
THF & Tetrahydrofuran \\
UVD & Ultra Violet detector
\end{tabular}

\section{Symbols}

$\mathrm{C}$

Concentration

$\left[\mathrm{kg} / \mathrm{m}^{3}\right]$

$\mathrm{C}_{1} / \mathrm{C}_{2} / \mathrm{C} \quad$ Positive constants related to conventional calibration curve (eq. 2)

f(v) Chromatogram (eq. 1)

$[-]$

$\mathrm{H} \quad$ Plate height (eq. 4)

[m]

L Length of the column packing (eq. 4)

[m]

M Molecular mass

[kg/mol]

m Mass

[kg]

$\mathrm{M}_{\mathrm{n}} \quad$ Number average molecular mass (eq. A.9)

[kg/mol]

$\mathrm{M}_{\mathrm{w}} \quad$ Weight average molecular mass (eq. A.10)

$[\mathrm{kg} / \mathrm{mol}]$

$\mathrm{N}$

Number of theoretical plates (eq. 4)

$[-]$

$t_{R} \quad$ Peak retention (eq. 4)

$\left[\mathrm{m}^{3}\right]$

Elution volume

$\left[\mathrm{m}^{3}\right]$

Peak width

$\left[\mathrm{m}^{3}\right]$

$\mathrm{W}$

Differential molecular weight distribution (eq. 1 and A.1) [mol]

$\alpha \quad$ Response factor (eq. 1 and 3)

$\left[\mathrm{m}^{3} / \mathrm{kg}\right]$

$\sigma$

Standard deviation (eq. A.2 and 4)

$\left[\mathrm{m}^{3}\right]$

\section{Sub- and superscripts}

i Single compound i (eq. A.2)

$0 \quad$ Peak of the curve (eq. A.2) 


\section{Appendix 6A From chromatogram to $\mathrm{M}_{\mathrm{w}}$ - distribution}

The molecular weight distribution (W(M) [mol]) is defined as the slope of the graph in which the cumulative mass is plotted against the molecular weight $(\mathrm{M}[\mathrm{g} / \mathrm{mol}])^{9}$. This distribution can be obtained from the chromatogram $(\mathrm{f}(\mathrm{v}))$ and the calibration curve that relates the elution volume to the molecular mass:

$W(M)=\frac{d m}{d M}=-\frac{d m}{d \mathrm{v}} \cdot \frac{d \mathrm{v}}{d M}$

\section{A.1 dm/dv}

This parameter can be quantified from the chromatogram. The SEC chromatogram of a single compound appears as a bell-shaped Gaussian peak. In the absence of secondary separation effects, the position of the peak (elution time) depends on the molecular size; the area under the curve is proportional to the concentration (in wt \%) and the width of the Gaussian curve depends on the column resolution ${ }^{31}$. For a polydispersed sample the chromatogram is a composite of the Gaussian curves of all individual compounds (see eq. $(\text { A.2) })^{31}$.

$$
f(\mathrm{v})=\sum_{i} \alpha_{i} m_{i} \frac{1}{\sigma_{i} \sqrt{2 \pi}} e^{\frac{-\left(\mathrm{v}-\mathrm{v}_{0_{i}}\right)^{2}}{2 \sigma_{i}^{2}}}
$$

Assuming the response factor $(\alpha)$ to be compound independent leads to the following equations:

$$
\begin{aligned}
& \int f(\mathrm{v}) d \mathrm{v}=\alpha \int \sum_{i} m_{i} \frac{1}{\sigma_{i} \sqrt{2 \pi}} e^{\frac{-\left(\mathrm{v}-\mathrm{v}_{0_{i}}\right)^{2}}{2 \sigma_{i}^{2}}} d \mathrm{v}=\alpha \cdot m \\
& \frac{d m}{d \mathrm{v}}=\frac{1}{\alpha} f(\mathrm{v})
\end{aligned}
$$

\section{A.2 dv/dM}

The derivative of the elution volume (v) with respect to the molecular mass is obtained from a calibration procedure. ${ }^{8}$ Normally, a conventional calibration procedure is used to convert the elution volume to the molar mass ${ }^{15,19,20,27}$ (eq. (A.5)).

$\log M=C_{1}-C_{2} \cdot \mathrm{v}$ 
Thus:

$\frac{d \mathrm{v}}{d M}=\frac{d \mathrm{v}}{d \log M} \cdot \frac{d \log M}{d M}=-\frac{1}{C_{2}} \frac{1}{M \ln 10}$

Filling in both terms eqs. (A.4) and (A.6) in eq. (A.2) gives the equation for the molecular weight distribution.

$W(M)=\frac{d m}{d M}=\frac{1}{\alpha C_{2}} \cdot \frac{1}{M \ln 10} \cdot f(\mathrm{v})$

In SEC research it is more common to report $\mathrm{W}(\log M)$ instead of $\mathrm{W}(\mathrm{M})^{9}$. In this case, each $\log (\mathrm{M})$ slice represents the same differential elution volume since the elution volume is proportional to $\log (\mathrm{M})$ (eq. (A.5)).

$W(\log M)=\frac{d m}{d \log M}=W(M) M \ln 10=\frac{1}{\alpha C_{2}} \cdot f(\mathrm{v}) \equiv C \cdot \frac{1}{\alpha} \cdot f(\mathrm{v})$

The number average molecular weight and weight average molecular weight can now be calculated using eqs (A.9) and (A.10) ${ }^{8,9}$.

$$
\begin{gathered}
M_{n}=\frac{\sum N_{i} M_{i}}{\sum N_{i}}=\frac{\int_{M_{1}}^{M_{2}} W(M) d M \quad}{\int_{M_{1}}^{M_{2}} \frac{W(M)}{M} d M \quad \frac{\int_{\log M_{2}}^{\log M_{1}} W(\log M) d \log M}{\int_{\log M_{2}}^{\log M)}} \frac{M_{2}}{M} d \log M} \\
M_{w} \equiv \frac{\sum N_{i} M_{i}^{2}}{\sum N_{i} M_{i}}=\frac{\int_{M_{1}}^{M_{2}} W(M) \cdot M d M}{\int_{M_{1}}^{M_{2}} W(M) d M}=\frac{\int_{\log M_{1}}^{\log M_{2}} W(\log M) \cdot M d \log M}{\int_{\log M_{2}} W(\log M) d \log M}
\end{gathered}
$$




\section{Appendix 6B Model compounds}

\begin{tabular}{|c|c|}
\hline $\begin{array}{l}\text { Anthracene } \\
\mathrm{C}_{14} \mathrm{H}_{10} \\
178 \mathrm{~g} / \mathrm{mol} \\
\text { (BDH, analytical standard) }\end{array}$ & 1 \\
\hline $\begin{array}{l}\text { Citric acid } \\
\mathrm{C}_{6} \mathrm{H}_{8} \mathrm{O}_{7} \\
192 \mathrm{~g} / \mathrm{mol} \\
\text { (Sigma-Aldrich, reagent grade) }\end{array}$ & $\mathrm{OH}$ \\
\hline $\begin{array}{l}\text { Eicosane } \\
\mathrm{C}_{20} \mathrm{H}_{42} \\
283 \mathrm{~g} / \mathrm{mol} \\
(\text { Fluka, purity }>99.8 \%)\end{array}$ & \\
\hline $\begin{array}{l}\text { Fluoranthene } \\
\mathrm{C}_{6} \mathrm{H}_{10} \\
202 \mathrm{~g} / \mathrm{mol} \\
\text { (Sigma-Aldrich, purity } 99 \% \text { ) }\end{array}$ & \\
\hline $\begin{array}{l}\text { Fmoc } \\
\mathrm{C}_{15} \mathrm{H}_{12} \mathrm{O}_{2} \\
224 \mathrm{~g} / \mathrm{mol}\end{array}$ & \\
\hline $\begin{array}{l}\text { Fmoc-Asp }(\mathrm{OtBu})-\mathrm{OH} \\
\mathrm{C}_{23} \mathrm{H}_{25} \mathrm{NO}_{6} \\
411 \mathrm{~g} / \mathrm{mol} \\
\text { (Fluka, purity }>98 \% \text { ) }\end{array}$ & $\mathrm{OH}$ \\
\hline
\end{tabular}




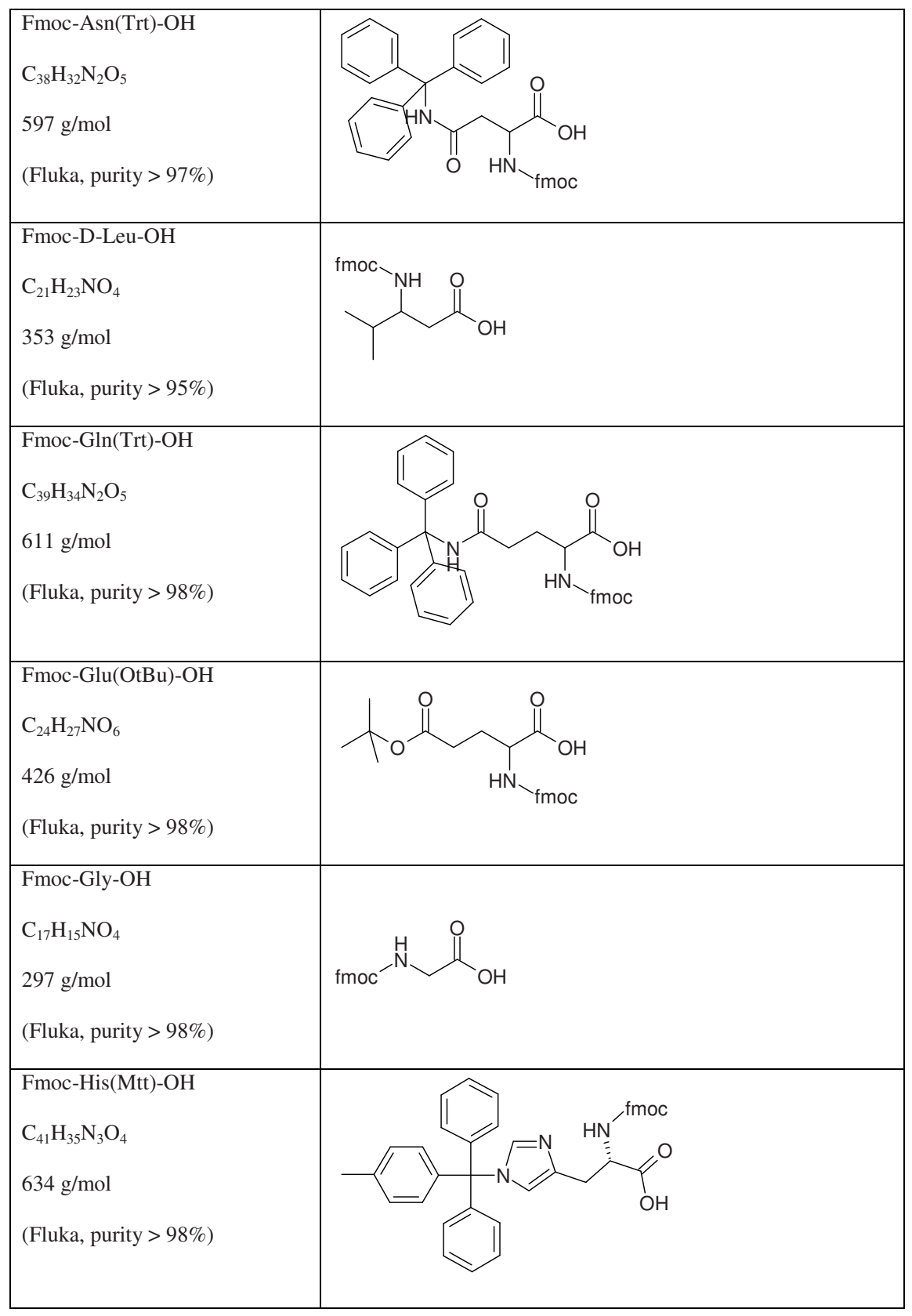


Possibilities and pitfalls in analyzing (upgraded) pyrolysis oil by size exclusion chromatography (SEC)

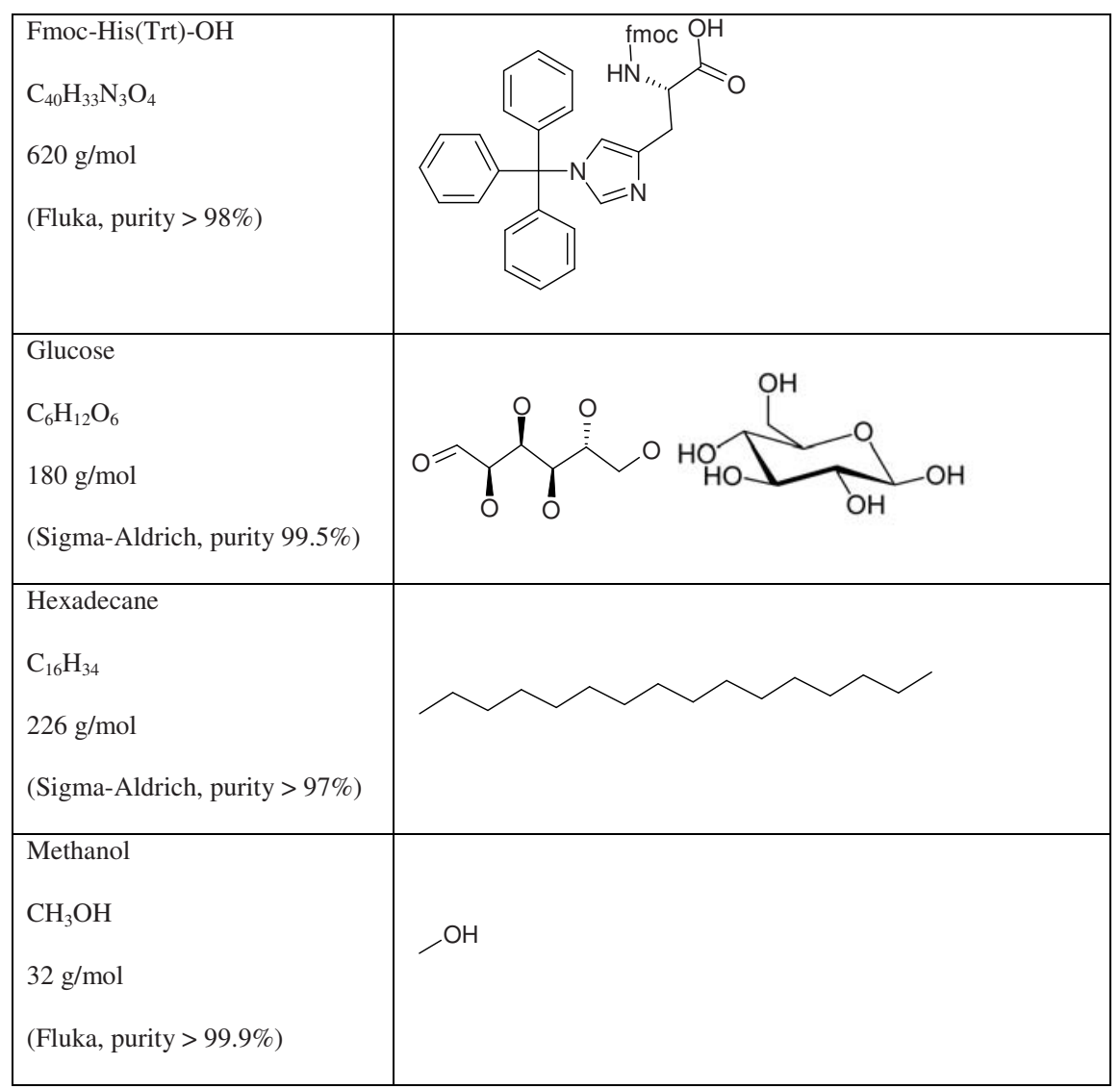




\section{References}

1. A.V. Bridgwater, Principles and practice of biomass fast pyrolysis processes for liquids, J. Anal. Appl. Pyrolysis, 51, 3- 22, 1999

2. K. Sipilä, E. Kuoppala, L. Fagernäs, A. Oasmaa, Characterization of biomass-based flash pyrolysis oils, Biomass and Bioenergy, 14(2), 102-113, 1998

3. S. Czernik, S., A.V. Bridgwater, Overview of applications of biomass fast pyrolysis oil, Energy and Fuels, 18 (2), 590-598, 2004

4. J.P. Diebold, A review of the chemical and physical mechanisms of the storage stability of fast pyrolysis bio-oils, Thermalchemie:Lakewood, 35, Colorado, 1999

5. A. Oasmaa, C. Peacocke, A guide to physical property characterization of biomass-derived fast pyrolysis liquids, VTT Technical Research Centre of Finland, Espoo, 2001

6. R.J.M. Westerhof, D.W.F. Brilman, S.R.A. Kersten, W.P.M. van Swaaij, Effect of temperature in fluidized bed fast pyrolysis of biomass: oil quality assessment in test units, Ind. Eng. Chem. Res., 49(3), 1160-1168, 2010

7. F. de Miguel Mercader, J.A. Hogendoorn, S.R.A. Kersten, N.W.J. Way, C.J. Schaverien, M.J. Groeneveld, Production of advanced biofuels: Co-processing of upgraded pyrolysis oil in standard refinery units, Applied Catalysis B: Environmental, 96, (1-2), 57-66, 2010

8. C.-S. Wu, Handbook of size exclusion chromatography, Chromatographic science series, v 69, New York : Dekker, 1995

9. K.H Atgelt, L.Segal, Gel Permeation Chromatography, New York, NY : Dekker, 1971

10. K.D. Bartle, M.J. Mulligan, N Taylor, T.G. Martin, C.E. Snape, Molecular mass calibration in size-exclusion chromatography of coal derivatives, Fuel, 63, 1556-1560, 1984

11. R.A. Greinke, L.H. O’Connor, Determination of molecular weight distributions of polymerized petroleum pitch by gel permeation chromatography with quinoline eluent, Anal. Chem., 52, (12), 1877-1881, 1980

12. K.H. Atgelt, T.H Gouw, Chromatography in petroleum analysis, chromatographic science series, vol. 11, New York : Dekker, 1979

13. V. Sanchez, E. Murgia, J.A. Lubkowitz, Size exclusion chromatographic approach for the evaluation of processes for upgrading heavy petroleum, Fuel, 63, 612-615, 1984

14. M. Behrouzi, P.F. Luckham, Limitations of size-exclusion chromatography in analyzing petroleum asphaltenes: a proof by automatic force microscopy, Energy and Fuels, 22, 1792-1798, 2008

15. P.T. Williams, D.T. Taylor, The molecular weight range of pyrolytic oils derived from tire waste, J. Anal. Appl. Pyrolysis, 29, 111-128, 1994

16. E.A. Williams, P.T. Williams, Analysis of products derived from the fast pyrolysis of plastic waste, J. Anal. Appl. Pyrolysis, 40-41, 347-363, 1997

17. W.J. Hall, P.T. Williams, Pyrolysis of brominated feedstock plastic in a fluidised bed reactor, J. Anal. Appl. Pyrolysis, 77, 75-82, 2006

18. P. Bhattacharya, P.H. Steele, E.B.M. Hassan, B. Mitchell, L. Ingram, C.U. Pittman, Wood/plastic copyrolysis in an augar reactor: chemical and physical analysis of the products, Fuel, 88, 12511260, 2009

19. B. Scholze, C. Hanser, D. Meier, Characterization of the water-insoluble fraction from fast pyrolysis liquids (pyrolytic lignin) Part II. GPC, carbonyl groups, and ${ }^{13} \mathrm{C}-\mathrm{NMR}$, J. Anal. Appl. Pyrolysis, 58-59, 387-400, 2001

20. S. Baumberger, A. Abaecherli, M. Fasching, G. Gellerstedt, R. Gosselink, B. Hortling, J. Li, B. Saake, E. de Jong, Molar mass determination of lignins by size-exclusion chromatography: towards standardization of the method, Holzforschung, 61, 459-468, 2007 
21. O. Ringena, S. Lebioda, R. Lehnen, B. Saake, Size-exclusion chromatography of technical lignins in dimethyl sulfoxide/water and dimethylacetamide, Journal of Chromatography A, 1102, 154163,2006

22. T.A. Milne, H.L. Chum, F. Agblevor, D.K. Johnson, Standardized analytical methods, Biomass and Bioenergy, 2 (1-6), 341-366, 1992

23. R. Bayerbach, V.D. Nguyen, U. Schurr, D. Meier, Characterization of water-insoluble fraction from fast pyrolysis (pyrolytic lignin). Part III. Molecular characterization by SEC, MALDI-TOFMS, LDI-TOF-MS, and Py-FIMS, J. Anal. Appl. Pyrolysis, 77, 95-101, 2006

24. S. Czernik, D.K. Johnson, S. Black, Stability of wood fast pyrolysis oil, Biomass and Bioenergy, 7, 187-192, 1994

25. E. Hoekstra, K.J.A. Hogendoorn, X. Wang, R.J.M. Westerhof, S.R.A. Kersten, W.P.M. van Swaaij, M.J. Groeneveld, Fast pyrolysis of biomass in a fluidized bed reactor: in situ filtering of the vapors, Ind. Eng. Chem. Res., 48, 4744-4756, 2009 (chapter 5 this thesis)

26. F. de Miquel Mercader, , M.J. Groeneveld, S.R.A. Kersten R.H. Venderbosch, J.A. Hogendoorn, Pyrolysis oil upgrading by high thermal treatment, Fuel, 89, (10), 2829-2837, 2010

27. M. Garcia-Perez, A. Chaala, H. Pakdel, D. Kreschmer, C. Roy, Characterization of bio-oils in chemical families, Biomass and Bioenergy, 31, 222-242, 2007

28. L. Ingram, D. Mohan, M. Bricka, P. Steele, D. Strobel, D. Crocker, B. Mitchell, J. Mohammad, K. Cantrell, C.U. Pittman, Pyrolysis of wood and bark in an augar reactor: physical properties and chemical analysis of the produced bio-oils, Energy and Fuels, 22(1), 614-625, 2008

29. A.Oasmaa, E. Kuoppala, Y. Solantausta, Fast Pyrolysis of forestry residue. 2. Physicochemical composition of product liquid, Energy and Fuels, 17(2), 433-443, 2003

30. D.K. Johnson, H.L. Chum, Some aspects of pyrolysis oils characterization by high performance size exclusion chromatography, ACS Symposium series, 376, 156-166, 1988

31. L.H Tung, Journal of Applied Polymer science, 10, 375 - 385, 1966

32. Www.agilent.com/chem/supplies, visited January 2010

33. R.J.M. Westerhof, N.J.M. Kuipers, S.R.A. Kersten, W.P.M van Swaaij, Controlling the water content of biomass fast pyrolysis oil, Ind. Eng. Chem. Res., 46(26), 9238-9247, 2007

34. A. Oasmaa, E. Kuoppala, S. Gust, Y. Solantausta, Fast pyrolysis of forestry residue 1. Effect of extractives on phase separation of pyrolysis liquids, Energy and Fuels, 17, (1), 1-12, 2003

35. CRC Handbook of Chemistry and Physics, $89^{\text {th }}$ Edition, 2008-2009

36. http://www2.ups.edu/faculty/hanson/labtechniques/refractometry/interpret.htm, visited January 2010

37. A. Oasmaa, E. Kuoppala, Solvent fractionation method with Brix for rapid characterization of wood fast pyrolysis liquids, Energy and Fuels, 22, 4245-4248, 2008

38. BASF Corporation, Tetrahydrofuran (THF), Storage and Handling, 1998

39. Skoog, West, Holler, Fundamentals of analytical chemistry, $7^{\text {th }}$ edition, Fort Worth, TX : Saunders, 1996

40. J. Wildschut, F.H. Mahfud, R.H. Venderbosch, H.J. Heeres, Hydrotreatment of fast pyrolysis oil using heterogeneous noble-metal catalysts, Ind. Chem. Res., 48, 10324-10334, 2009 


\section{Main conclusions}

The large scale application of second generation biomass conversion technologies in which lignocellulosic biomass is converted to bio-energy and bio-chemicals will contribute to global sustainability. Fast pyrolysis in which biomass is converted into an easier to handle liquid (pyrolysis oil) containing hundreds of different organic/oxygenated chemicals, is one the considered technologies. In fast pyrolysis organic material (moisture content typically $<10 \mathrm{wt} \%$ ) is thermally decomposed at 400 $600{ }^{\circ} \mathrm{C}$ in the absence of oxygen into char (typically 15-25 wt \%), permanent gases (10-20 $\mathrm{wt} \%$ ) and pyrolysis vapors/aerosols (both denoted as vapors here) which form the oil after cooling and condensation (typical yield 60-70 wt\%).

Besides direct use for combustion and flavor production, pyrolysis oil is considered to be an intermediate to be used in subsequent processes. Pyrolysis oil has the potential to replace crude 'fossil oil' to produce fuels and chemicals. The potential of fast pyrolysis as biomass pre-treatment step is directly related to the significantly higher density of the oil $\left(\sim 1200 \mathrm{~kg} / \mathrm{m}^{3}\right)$ compared to the original biomass $\left(\sim 150 \mathrm{~kg} / \mathrm{m}^{3}\right)$ and the resulting transportation benefits. This leads to the concept of small decentralized fast pyrolysis plants for production of oil to be transported to a central processing plant.

This thesis presents research results on the fast pyrolysis of biomass and has been carried out to provide a better understanding of the fast pyrolysis process. The influences of feedstock (especially mineral content) and various process parameters (like temperature, pressure, heating rate, biomass size, vapor phase and biomass residence time) were studied.

Below, the main conclusions are presented per investigated item.

\section{Size Exclusion Chromatography (SEC)}

It is difficult to analyze pyrolysis oil with a single technique, because of the intrinsic instability and complex nature of the oil. A technique to obtain information about the complete (upgraded) pyrolysis oil under mild analysis conditions $\left(30-40{ }^{0} \mathrm{C}\right)$ is size exclusion chromatography (SEC). This technique was also frequently used in this thesis. However, the limitations and possibilities of this technique are not well understood and were therefore studied. Results showed that the absolute $\mathrm{M}_{\mathrm{w}}$-distribution, $\mathrm{M}_{\mathrm{n}}$ (number average molecular weight) and $\mathrm{M}_{\mathrm{w}}$ (weight average molecular weight) of (upgraded) pyrolysis oil cannot be obtained using SEC. In the conversion procedure of the chromatogram to the $\mathrm{M}_{\mathrm{w}}$-distribution, assumptions related to the conversion of the elution volume to the molecular weight and the RI signal to the concentration are 
erroneous when applied to (upgraded) pyrolysis oil. However, SEC can supply valuable information when used to compare (upgraded) pyrolysis oil samples. Besides information about the relative $\mathrm{M}_{\mathrm{w}}$-distributions, information about the chemical structure can be obtained by comparing the results from the UV and RI-detector.

\section{Initial decomposition products: pyrolysis in a novel wire-mesh reactor:}

An important research goal was to study experimentally the initial decomposition processes. To realize this, the influence of vapor phase reactions on yield and composition must be minimized. For this a unique wire-mesh reactor was designed, constructed and validated. Characteristics of this set-up were:

- High heating rates of around $7 \cdot 10^{3}{ }^{0} \mathrm{C} / \mathrm{s}$ of a thin biomass sample (thickness 45 $\mu \mathrm{m})$ were achieved;

- The reactor was operated under vacuum $(\mathrm{P}<0.3$ mbar) and with liquid nitrogen cooling to ensure condensation of pyrolysis vapors within $15-25 \mathrm{~ms}$;

- Low vapor temperatures were realized; temperatures lower than $-80{ }^{0} \mathrm{C}$ were measured within $2 \mathrm{~cm}$ of the sample;

- Mass balance closures between 90 and 110 wt $\%$ were obtained;

- Reproducible results concerning oil (SEC, NMR), gas (GC) and char (FTIR) composition were obtained.

Char is known to be formed from levoglucosan and glucose under "conventional" pyrolysis conditions. These compounds were vaporized/sublimated and recovered as products without the occurrence of chemical reactions in the wire-mesh reactor showing that decomposition reactions inside the sample and vapor phase reactions were efficiently suppressed.

With the new device very high oil and low char and gas yields were obtained upon the pyrolysis of pine wood, cellulose and lignin compared to "conventional" fast pyrolysis processes. In our "conventional" $1 \mathrm{~kg} / \mathrm{hr}$ fluidized bed reactor using pine wood as feed ( $\tau_{\text {vapors }} 1-2 \mathrm{~s}$, same feedstock, particle size $\sim 1 \mathrm{~mm}$ ), the oil, char and gas yield were 60,15 and $25 \mathrm{wt} \%$, respectively. In the wire-mesh reactor, the oil yield for pine wood, lignin and cellulose at $500{ }^{\circ} \mathrm{C}$ were 84, 78 and $95 \mathrm{wt} \%$; the char yield 5, 12 and $0 \mathrm{wt} \%$ and the gas yield 8, 7 and $4 \mathrm{wt} \%$, respectively. In the wire-mesh reactor at $700{ }^{\circ} \mathrm{C}$, the oil yield obtained for pine-wood was still $60 \mathrm{wt} \%$. Results indicated that the initial biomass conversion process is much faster (completed within $\sim 0.5 \mathrm{~s}$ ) than can be derived from experimental results and kinetic expressions in literature.

The liquid nitrogen cooling appeared to be mainly responsible for the suppression of cracking reactions of vapors to gases, while vacuum prevented the occurrence of charring 
reactions by enhancing the removal of volatiles from the (decomposing) biomass. When lowering the heating rate from the standard $7.0 \cdot 10^{3}$ to $5 \cdot 10^{1}{ }^{0} \mathrm{C} / \mathrm{s}$, i.e. a typical heating rate of a $2 \mathrm{~mm}$ particle in a fluidized bed pyrolysis reactor, a decline in oil yield and an increase in gas (especially $\mathrm{CO}_{2}$ ) and char yield were observed for all feedstocks. Minerals were shown to directly enhance charring reactions inside the decomposing biomass particles (in the solid or liquid state); the char yield for potassium impregnated pinewood (10 wt $\%$ char) was twice as large as the one obtained using untreated wood (5 wt $\%$ char).

In conclusion, we observed high oil yields in our wire-mesh reactor due to i) the strong suppression of vapor phase reactions outside, but also inside the biomass layer ii) the extremely high heating rates and iii) the efficient removal of liquid and solid decomposition products from the biomass matrix .

Although differences in oil characteristics between the one from the wire mesh reactor and the one obtained in a "conventional" fluidized pyrolysis could be observed, these were generally modest. When comparing the molecular weight of the various oils, it was found that upon a decrease in the extent of reactions in the (decomposing) biomass and in the vapor phase, the molecular weight of the oil increased. Other than this, the pyrolysis oil produced in the wire mesh reactor contained a white, THF insoluble, sugar fraction. Besides levoglucosan, also larger sugars were indentified in this fraction. This sugar fraction is likely to originate from cellulose and hemicellulose.

\section{Homogeneous vapor phase reactions}

Homogeneous reactions of pyrolysis vapors from pine wood were studied using a heated tubular reactor $\left(400-550{ }^{\circ} \mathrm{C}\right)$. A feed stream of clean pyrolysis oil vapors was produced in a fluidized bed reactor $\left(500{ }^{0} \mathrm{C}, 0.15 \mathrm{~kg} / \mathrm{hr}\right)$ connected to a downstream hot gas filter (wire-mesh filter, pore size of $5 \mu \mathrm{m}$ ). By using different lengths of the tubular reactor (111 meters) it was possible to vary the residence time between 1-15 s while keeping the vapor's concentration constant. A novel jacketed cooled ESP was used as main condenser.

A decrease in average molecular weight, lignin content and an increase in gas yield (especially CO, only at temperatures higher than $400{ }^{\circ} \mathrm{C}$ ) and phenols (GC/MS) was observed as the residence time increases which are all indicators for an increase in the extent of cracking reactions. No increase in char yield and water production was observed which are indicators for the occurrence of polymerization reactions. Homogeneous cracking reactions were thus dominant over polymerization reactions in the range studied. At $400{ }^{\circ} \mathrm{C}$ the oil and gas yield were independent on the residence time, although the changes in oil composition indicated that reactions had occurred. At and above a vapor temperature of $500{ }^{0} \mathrm{C}$ the gas yield increased and oil yield decreased initially with 
residence time; no extra char formation was observed. The results showed that a temperature dependent oil yield asymptote is reached provided that long enough vapor residence times are applied $\left(400{ }^{\circ} \mathrm{C}: 62 \mathrm{wt} \%, 500{ }^{\circ} \mathrm{C}: 57 \mathrm{wt} \%, 550{ }^{0} \mathrm{C}: 49 \mathrm{wt} \%_{\text {daf }}\right)$.

The following trend at $500{ }^{\circ} \mathrm{C}$ emerges when combining these data with the data obtained in the wire-mesh reactor: a very quick drop in oil yield (84-62 wt\%) yield in the first few ms was observed after which a more gradual decline (62-57 wt\%) was observed till a constant value was reached at about $5 \mathrm{~s}$. A generally postulated process requirement is that short vapor residence time of typically less than $2 \mathrm{~s}$ are needed to obtain high oil yields ${ }^{1}$. No experimental justification for the use of " $2 \mathrm{~s}$ " was found in our study. To really maximize the oil yield, much lower vapor residence times are required. If the vapor residence time is in the order of seconds, lowering the temperature to $400{ }^{0} \mathrm{C}$ is sufficient to stop cracking reactions.

\section{Heterogeneous reactions of the vapor phase}

The influence of heterogeneous reactions of pyrolysis vapors were studied using a fluidized bed reactor $\left(400-530{ }^{0} \mathrm{C}, \sim 0.8 \mathrm{~kg} / \mathrm{hr}, \tau \sim 2 \mathrm{~s}\right.$, pine wood) in which the char/mineral hold-up could be controlled.

Char, viz. the organic $\mathrm{C}, \mathrm{H}$ and $\mathrm{O}$ atoms, appeared not to be catalytically active inside the fluidized bed reactor. However, the presence of minerals $(\mathrm{Na} / \mathrm{K})$-either in the biomass matrix (native or impregnated) or external (as salt or in char)- does influence the fast pyrolysis process. Heterogeneous vapor phase charring/polymerization reactions were more important than cracking reactions of vapors to gas. The char yield even increased from 16 till $42 \mathrm{wt} \%$ when a weight fraction of $0.7 \mathrm{wt} \%$ of $\mathrm{Na}$ and $\mathrm{K}$ was present in the fluidized bed reactor. Although minerals influence the initial decomposition reactions (see experiments in wire-mesh reactor) this could not be established in this study because of the predominance of external interactions between the vapors and $\mathrm{Na} / \mathrm{K}$ rich solids in the studied range. From this study it was concluded that the contact time between vapors and minerals, whether or not incorporated in char/biomass, needs to be minimized. However, the presence of mineral free char does not affect yields.

\section{In situ filtration}

The results described above led to the concept of in situ filtration in which char, typically retaining the minerals from the feed, is separated from the hot pyrolysis vapor stream inside the fluidized bed reactor. The system consisted of a fluidized bed reactor $(0.7 \mathrm{~kg} / \mathrm{h})$ with an immersed wire-mesh filter with a pore size of $5 \mu \mathrm{m}$ and a downstream cyclone. About half of the pyrolysis vapors were removed from the reactor via the filter and the other half via the cyclone. Pine wood containing $0.6 \mathrm{wt} \%$ ash was used as feedstock in these experiments. Integration of the filter system in the fluidized bed was shown to overcome operational problems related to the increase in pressure drop across the filter in 
time. Moreover, the oil yield loss that is typical for downstream pyrolysis vapor filtration was not observed. The filtered oil contained significantly less solids, alkali metals and ash as compared to cyclone oil, which might be advantageous for certain applications. Only a considerable amount of potassium $(\mathrm{K})$ was still present in filtered pyrolysis oil, which is probably caused by the relatively high volatility of the potassium salts. Results of pyrolysis oil aging tests $\left(24\right.$ hours storage at $80{ }^{\circ} \mathrm{C}$ ) did not show an increase in stability for the pyrolysis oil produced using in situ filtration. Apparently, the instability of pyrolysis oil can already originate from the highly reactive components in pyrolysis oil itself and does not need the presence of char/ash.

\section{Fast pyrolysis mechanisms}

The combined results of the initial decomposition processes and subsequent vapor reactions were united in a fast pyrolysis mechanism. The basic concept behind the decomposition mechanism is that the amount and composition of the decomposing biomass, which can be in the solid and liquid state, is changing in time due to competition between (cross)-linking reactions, scission reactions and mass transfer of decay fragments out of the (decomposing) biomass (by physical entrainment, sublimation and vaporization). The results obtained in the wire mesh reactor were successfully interpreted with this mechanism. The ratio of scission reactions over (cross)-linking reactions increased with temperature (and so heating rates) and decreased in the presence of $\mathrm{K}$ and residence time of decay fragments (solid/liquid) in the decomposing biomass particles. Moreover, the ratio of scission reactions over (cross)-linking reactions was also dependent on the feedstock: lignin appeared to yield much more char than cellulose, indicating a higher level of cross-linking reactions. If not immediately cooled and condensed, the volatiles formed upon the initial decomposition reactions (aerosols, vapors, gases) react further via a sequence of reactions in the vapor phase. Cracking reactions were dominant over polymerization reactions in a char/mineral free vapor stream, while the opposite was true in the presence of minerals.

The work in this thesis contributes to a better understanding and predictability of the fast pyrolysis process. Although the results were obtained in laboratory set-ups and some of the conditions might be difficult, if not impossible, to realize in traditional pyrolysis processes these facts and knowledge about the underlying phenomena might help in improving current and developing new pyrolysis technologies.

\section{References}

1. A.V. Bridgwater, Review of fast pyrolysis of biomass and product upgrading, Biomass and Bioenergy, 2011, article in press 


\section{Dankwoord}

De afgelopen vijf jaar heb ik met veel plezier aan dit proefschrift gewerkt, maar desondanks ben ik erg blij dat mijn proefschrift eindelijk in deze vorm voor u ligt. Bij deze wil ik iedereen bedanken die betrokken is geweest bij mijn promotieonderzoek. Zonder jullie hulp was dit proefschrift niet tot stand gekomen. In het bijzonder wil ik de onderstaande personen bedanken.

Allereerst wil ik de vijf personen bedanken die mij de afgelopen jaren begeleid hebben. Het was erg leerzaam om al jullie verschillende invalshoeken mee te krijgen. Ik heb versteld gestaan van jullie enorme hoeveelheid kennis en de vele discussies zijn van grote waarde geweest voor mijn promotiewerk. Ik wil graag mijn promotoren Wim van Swaaij en Sascha Kersten, in eerste instantie dagelijks begeleider en later promotor, bedanken voor de mogelijkheid die jullie me hebben geboden om na mijn afstudeeronderzoek als promovendus verder te gaan. Wolter Prins, jij was in het begin mijn begeleider. Maar ook de gesprekken die we hebben gevoerd toen je inmiddels al professor aan de universiteit van Gent was zijn voor mij zeer waardevol geweest. Kees Hogendoorn, jij werd als opvolger van Wolter Prins mijn begeleider. Samen hebben we meer structuur gegeven aan de opgezette onderzoekslijnen. Jouw inzicht in wetenschappelijk schrijven heeft de kwaliteit van mijn proefschrift aanzienlijk verbeterd. Ik wil je graag bedanken voor alle tijd die je voor mij hebt vrijgemaakt. Mijn speciale dank gaat uit naar mijn promotor Michiel Groeneveld die helaas veel te jong is overleden. Jouw enthousiasme werkte ontzettend motiverend.

I would like to acknowledge the EU for funding this work through the 6th Framework Program. For me it was very exciting to be part of a large European research project (BIOCOUP). This gave me the opportunity to have input in my research project from people working in industry and university in disciplines like catalysis, analysis and process engineering. Particularly, I would like to thank Agnes Ardiyanti (RUG) and Michael Windt (vTI) for helping me with analyzing the pyrolysis oil. The project also ensured diversity within my work: meetings, workshops, tasks/ deliverables and courses.

Aan dit promotieonderzoek hebben een aantal stagelopers en afstudeerders hun bijdrage geleverd. Ik heb ervan genoten om als team samen te werken. Aljosha Hupje, Mathijs Hofstee, Miriam Boegborn, Annegreet Boekeloo en Maarten Kropman, graag wil ik jullie bedanken voor jullie bijdrage aan hoofdstuk 2 en 3. Stijn Oudenhoven en Ron van Dorp wil ik bedanken voor hun bijdrage aan hoofdstuk 4 and Umay Kayaalp for her contribution to chapter 6 . 
Benno Knaken, Robert Brouwer, Karst van Bree en Henk Naafs zonder jullie was het niet mogelijk geweest om het experimentele werk uit te voeren. Ik heb het als erg leuk en leerzaam ervaren om samen met jullie nieuwe opstelling te ontwerpen, te bouwen en te testen. Graag wil ik Robert Meijer, Rindert Nauta, Casper Klop en Peter Schutte bedanken voor het beantwoorden van al mijn Labview vragen. Erna Fränzel-Luiten wil ik bedanken voor haar hulp bij het uitvoeren van de analyses en Yvonne-Bruggert ter Huurne voor de secretariële zaken die ze voor mij de afgelopen jaren heeft uitgevoerd.

Thanks to al my (old) TCCB-colleagues for my pleasant time in the group! We had many usefull research related discussions. Particulary, I would like to thank Roel Westerhof for all the usefull pyrolysis discussions and Ferran de Miguel Mercader for being my "BIOCOUP" colleague. But besides that, I will always have great memories to the coffee/lunh-breaks, many drinks and TCCB-trips.

Ook wil ik graag alle mensen bedanken die niet direct betrokken waren bij het tot stand komen van mijn proefschrift. Ik wil graag iedereen bedanken waarmee ik de afgelopen jaren samen heb gebadmintond, gewandeld en gezeldschapspelletjes heb gespeeld. Ik wil mijn familie, schoonfamilie en met name mijn ouders bedanken voor hun steun. Mijn paranimfen Susanne Jannink en Marloes Kuiper-Hartman wil ik bedanken voor de hulp tijdens de laatste voorbereidingen van mijn verdediging. Pieter, jouw wil ik graag als laatste bedanken: ik heb je zorgzaamheid, geduld, liefde en steun de afgelopen jaren enorm gewaardeerd!

Elly Hoekstra, September 2011 



\section{Publications and Presentations}

E. Hoekstra, J.A. Hogendoorn, X. Wang, R.J.M. Westerhof, S.R.A. Kersten, W.P.M. van Swaaij, M.J. Groeneveld, Fast pyrolysis of biomass in a fluidized bed reactor: in situ filtering of the vapors

Ind. Eng. Chem. Res., 48, 4744-4756, 2009

Netherlands Process Technology Symposium, Veldhoven, 2008

Presentation: Fast Pyrolysis of biomass: char removal by in-situ filtering of pyrolysis vapors

Symposium on Thermo and Catalytic Sciences for Biofuels and Biobased Products (TCS2010) Iowa State University, 2010

Presentation: Primary fast pyrolysis products from pine-wood. A comparison between wire mesh and fluidized bed pyrolysis

E. Hoekstra, S R.A. Kersten, A. Tudos, D. Meier, J.A. Hogendoorn

Possibilities and pitfalls in analyzing (upgraded) pyrolysis oil by size exclusion chromatography (SEC)

J. Anal. Appl. Pyrolysis, 91, 76-88, 2011

E. Hoekstra, R.J.M. Westerhof, M. Windt, W. Brilman, W.P.M. van Swaaij, S.R.A. Kersten, J.A. Hogendoorn

Heterogeneous and homogeneous reactions of pyrolysis vapors from pine wood Accepted for publication in AIChE Journal

E. Hoekstra, W.P.M. Van Swaaij, S. R.A. Kersten, Kees J.A. Hogendoorn

Fast pyrolysis in a novel wire-mesh reactor: Initial decomposition products of pine wood Submitted for publication, 2011

E. Hoekstra, W.P.M. Van Swaaij, S. R.A. Kersten, Kees J.A. Hogendoorn Fast pyrolysis in a novel wire-mesh reactor: Decomposition reactions of pine wood and model compounds

Submitted for publication, 2011 
